Prepared in cooperation with the U.S. Fish and Wildlife Service-Region 2-National Wildlife Refuge System, the Havasu National Wildlife Refuge, and the Desert Landscape Conservation Cooperative

\title{
Assessment of Ecosystem Response to a Temporary Water Level Drawdown and Subsequent Refilling at Topock Marsh, Arizona-July 2011-October 2014
}
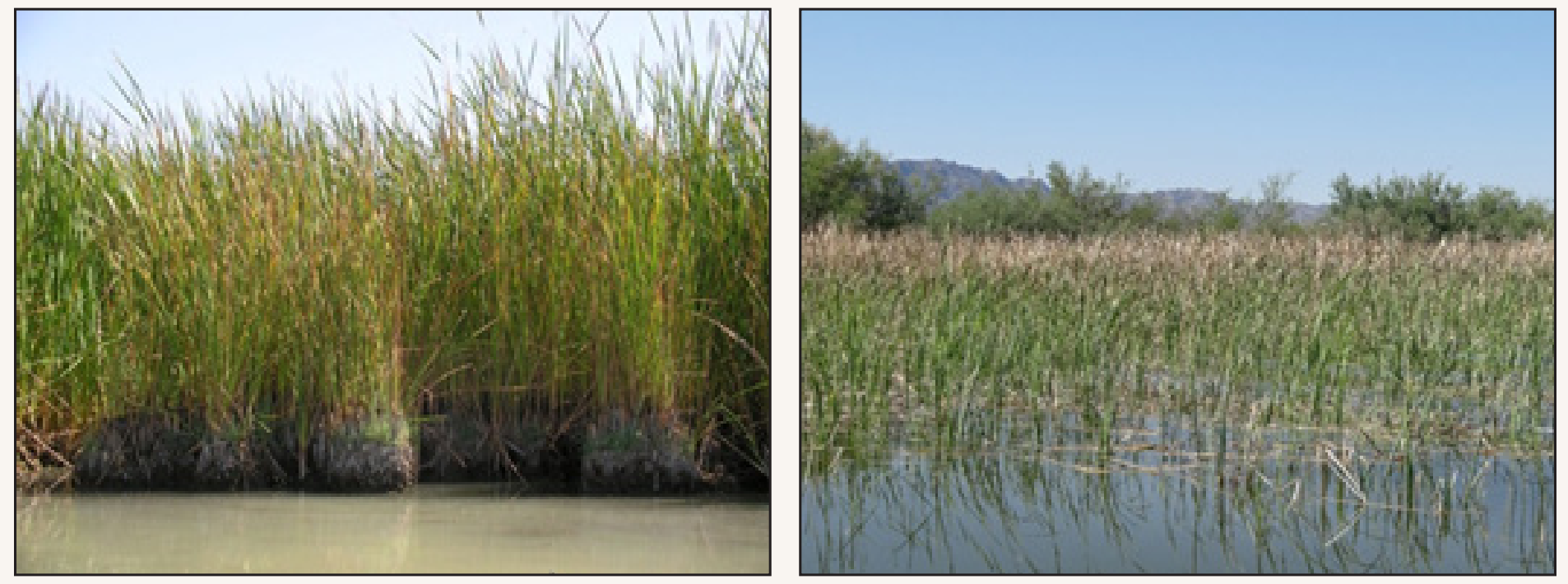

Open-File Report 2016-1195 
Cover. Photo 1-Cattail stand in Topock Marsh in September 2011 during low water conditions. Note how the cattail roots and rhizomes are above the water line and many of the leaves are brown. (Photo credit: Joan Daniels, U.S. Geological Survey) Photo 2-Cattail stand in Topock Marsh on April 20, 2014, during high water conditions. (Photo credit: Joan Daniels, U.S. Geological Survey) 


\section{Assessment of Ecosystem Response to a Temporary Water Level Drawdown and Subsequent Refilling at Topock Marsh, Arizona-July 2011-October 2014}

By Joan S. Daniels and Jeanette C. Haegele

Prepared in cooperation with the U.S. Fish and Wildlife ServiceRegion 2-National Wildlife Refuge System, the Havasu National

Wildlife Refuge, and the Desert Landscape Conservation Cooperative

Open-File Report 2016-1195 


\title{
U.S. Department of the Interior SALLY JEWELL, Secretary
}

\section{U.S. Geological Survey Suzette M. Kimball, Director}

\author{
U.S. Geological Survey, Reston, Virginia: 2017
}

For more information on the USGS - the Federal source for science about the Earth, its natural and living resources, natural hazards, and the environment—visit http://www.usgs.gov or call 1-888-ASK-USGS.

For an overview of USGS information products, including maps, imagery, and publications, visit http://store.usgs.gov.

Any use of trade, firm, or product names is for descriptive purposes only and does not imply endorsement by the U.S. Government.

Although this information product, for the most part, is in the public domain, it also may contain copyrighted materials as noted in the text. Permission to reproduce copyrighted items must be secured from the copyright owner.

Suggested citation:

Daniels, J.S., and Haegele, J.C., 2017, Assessment of ecosystem response to a temporary water level drawdown and subsequent refilling at Topock Marsh, Arizona-July 2011-October 2014: U.S. Geological Survey Open-File Report 2016-1195, 93 p., https://doi.org/10.3133/ofr20161195.

ISSN 2331-1258 (online) 


\section{Contents}

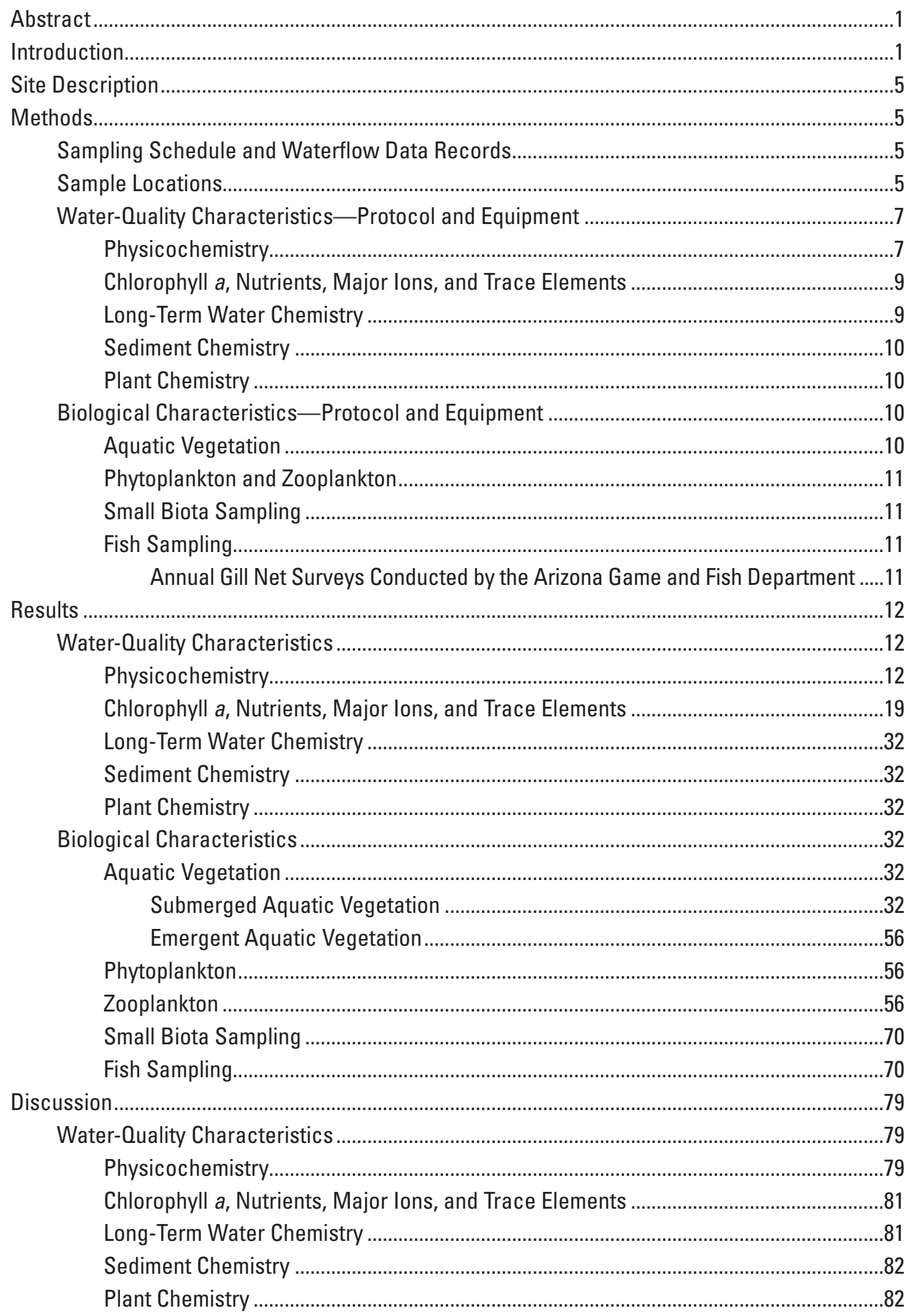




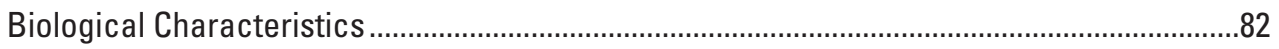

Aquatic Vegetation .............................................................................................. 82

Phytoplankton, Zooplankton, and Aquatic Macroinvertebrates........................................84

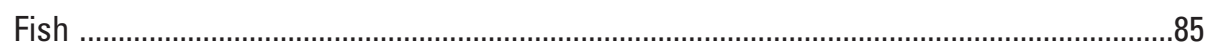

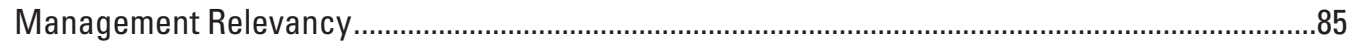

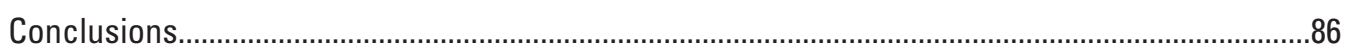

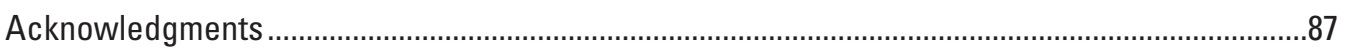

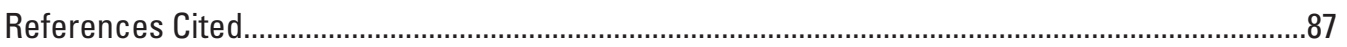

Appendix 1. Long-Term Water Chemistry Data for Topock Marsh From Late 1983

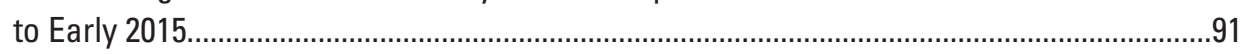

Appendix 2. Topock Marsh General Fish Surveys and Reports..................................................92

\section{Figures}

1. Map showing the location of 3 water irrigation canals (Topock Inlet, Fire Break, and Farm Ditch) and 10 biotic and abiotic sampling stations within

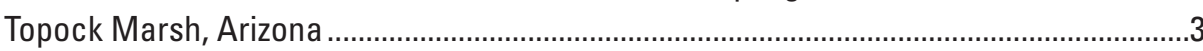

2. Graphs showing Topock Marsh, Arizona, inlet flows and water elevations at the South Dike from January 2009 to October 2014. .4

3. Graphs showing air temperature and wind speed recorded at the Needles Airport, California, weather station from July 1, 2011 to December 31, 2014 .6

4. Depth profiles of water temperatures in Topock Marsh during 2011 and 2012 and 2013 and 2014 at sampling stations TP-3, TP-2, TP-6, and TP-8

5. Graphs showing diurnal temperatures in Topock Marsh at sampling stations TP-3, TP-2, TP-6, and TP-8 during site visits from July 2011 to March 2012 and from June 2013 to September/October 2014

6. Depth profiles of specific conductance in Topock Marsh during 2011 and 2012 and 2013 and 2014 at sampling stations TP-3, TP-2, TP-6, and TP-8

7. Graphs showing diurnal specific conductance in Topock Marsh at sampling stations TP-3, TP-2, TP-6, and TP-8 during site visits from July 2011 to March 2012 and June 2013 to September/October 2014.

8. Depth profiles of pH in Topock Marsh during 2011 and 2012 and 2013 and 2014 at sampling stations TP-3, TP-2, TP-6, and TP-8.

9. Graphs showing diurnal pH in Topock Marsh at sampling stations TP-3, TP-2, TP-6, and TP-8 during site visits from July 2011 to March 2012 and from June 2013 to September/October 2014

10. Depth profiles of dissolved oxygen in Topock Marsh during 2011 and 2012 and 2013 and 2014 at sampling stations TP-3, TP-2, TP-6, and TP-8.

11. Graphs showing diurnal dissolved oxygen in Topock Marsh at sampling stations TP-3, TP-2, TP-6, and TP-8 during site visits from July 2011 to March 2012 and from June 2013 to September/October 2014

12. Graph showing surface water turbidity in Topock Marsh at sampling stations TP-3, TP-2, TP-6, and TP-8 from July 2011 to October 2014 
13. Depth profiles of turbidity and concurrent Secchi depths in Topock Marsh during 2011 and 2012 and 2013 and 2014 at sampling stations TP-3, TP-2, TP-6, and TP-8

14. Graph showing diurnal turbidity in Topock Marsh at sampling stations TP-3,

TP-2, TP-6, and TP-8 during site visits from June 2013 to September/October 2014

15. Graphs showing surface water chlorophyll a concentrations in Topock Marsh at sampling stations TP-3, TP-2, TP-6, and TP-8 from July 2011 to October 2014, shown by sampling station and by sampling date

16. Graph showing concentration of total phosphorus, organic nitrogen, and total nitrogen in Topock Marsh at sampling stations TP-3, TP-2, TP-6, and TP-8 during site visits from July 2011 to September/October 2014

17. Stiff diagrams showing distribution of major ion chemistry during September/ October 2011 in Topock Marsh at sampling stations TP-3, TP-2, TP-6, and TP-8 _...........29

18. Stiff diagrams showing distribution of major ion chemistry in October 2013 in Topock Marsh at sampling stations TP-3, TP-2, TP-6, and TP-8.

19. Stiff diagrams showing distribution of major ion chemistry for September 30October 1, 2014, in Topock Marsh at sampling stations TP-3, TP-2, TP-6, and TP-8

20. Graph showing historical specific conductance in Topock Marsh from November 1983 to April 2015

21. Map showing submerged aquatic vegetation sampling from July 2011 to October 2014 along transects within Topock Marsh, Arizona.

22. Scatterplot of coverage values for the submerged aquatic vegetation in Topock Marsh, Arizona, during October 2011, October 2013, and October 2014 in relation to water depth and turbidity measurements for each observation point...........55

23. Graphs showing density and biovolume of phytoplankton data from sampling stations in Topock Marsh, Arizona, from August 2011 to October 2014

24. Graphs showing density and biomass of zooplankton data from sampling stations in Topock, Arizona, from October 2011 to October 2014.

25A. Map of the northern portion of Topock Marsh showing Arizona Game and Fish Department's gill net locations, 2010-15.

25B. Map of the southern portion of Toprock Marsh showing Arizona Game and Fish Department's gill net locations, 2010-15.

26. Graph showing the average number of fish captured per gill net per year in Topock Marsh by species.

\section{Tables}

1. Parameters and specific data sampled within Topock Marsh from July 2011 to October 2014

2. Dates, analyses, and locations where the various samples were taken in Topock Marsh from July 2011 through October 2014

3. Topock Marsh average water surface elevations and average waterflow rates during each biotic and abiotic sampling trip from July 2011 through October 2014

4. Concentrations of water-quality constituents collected from Topock Marsh in July, September, and October 2011; February and March 2012; June, July, and October 2013; and February, April, and September/October 2014 
5. Elemental analyses of water at four sampling stations in Topock Marsh during October 2011, July 2013, and September/October 2014

6. Analyses of Topock Marsh sediment samples collected in October 2011, July 2013, and October 2014.

7. Analyses of Topock Marsh plant samples collected in July 2013 and October 2014 ..........37

8. Submerged aquatic vegetation coverage ratings along east-west transects within Topock Marsh from July 2011 to October 2014.

9. Submerged aquatic vegetation presence ratios by sampling transect within Topock Marsh from October 2011 to October 2014..

10. Phytoplankton taxa collected in Topock Marsh at each sample station on each sampling date

11. Zooplankton taxa collected in Topock Marsh at each sampling station on each sampling date

12. Macroinvertebrate taxa and number of individuals collected in Topock Marsh at each sample station on each sampling date.

13. Summary of fish captured per net by Arizona Game and Fish Department using experimental gill nets each February from 2010 to 2015 


\title{
Assessment of Ecosystem Response to a Temporary Water Level Drawdown and Subsequent Refilling at Topock Marsh, Arizona-July 2011-October 2014
}

\author{
By Joan S. Daniels and Jeanette C. Haegele
}

\section{Abstract}

Topock Marsh is a 1,637-hectare (4,045-acre) wetland adjacent to the Colorado River near Needles, California, and a main feature of Havasu National Wildlife Refuge (NWR). The U.S. Fish and Wildlife Service, in cooperation with the Bureau of Reclamation, began construction of an infrastructure improvement project in 2010 to increase the efficiency of water use and to help protect the habitats and species found within the Havasu NWR. During construction, normal water delivery from the Colorado River into Topock Marsh through the Inlet Canal was restricted, which resulted in unusually low water elevations in 2011. The U.S. Geological Survey, commissioned by the U.S. Fish and Wildlife Service, undertook the investigation of the water quality and aquatic flora and fauna during the low water conditions. Subsequently, water elevations in the marsh returned to more normal elevations after the new concrete-lined Fire Break Canal became fully operational in January 2012.

The U.S. Geological Survey made 11 field trips to the Havasu NWR between July 2011 and October 2014 to assess the effects of the temporary low water conditions and the change of inflow location (from the Inlet Canal to the Fire Break Canal) on water quality and aquatic habitat. The following conditions were monitored: water quality, sediment and plant chemistry, phytoplankton, zooplankton, aquatic macroinvertebrates, and emergent and submerged aquatic vegetation (SAV). Water-quality and biota data collected during 2013-14 were then compared with data collected during the 2011-12 low water period.

Once the new Fire Break Canal became operational and Colorado River water flowed regularly into the marsh, concentrations of several water quality parameters decreased (for example, specific conductance, total dissolved solids, turbidity, chlorophyll $a$, and total and organic nitrogen), and phytoplankton abundance was reduced at the upstream sampling stations (TP-3, TP-2, and TP-6); the water flow pushed water with higher concentrations of these components downstream (measured at TP-8). The upstream sampling locations in
2013-14 had decreased turbidity, therefore more SAV biomass accumulated, especially in shallow areas with water depths of $\leq 1.0$ meter ( $\leq 3.3$ feet). However, the furthest downstream station had higher turbidity caused by both the suspension of autochthonous sediment and high phytoplankton density and biovolume. This higher turbidity resulted in minimal SAV growth, especially in the deeper water $(>1.0$ meter [ $>3.3$ feet]). Emergent vegetation not only survived the low water conditions of 2011, but expanded its areal coverage and subsequently thrived in the higher water elevations.

Overall, no immediate critically negative consequences were detected for aquatic fauna or flora that could be attributed unequivocally to the effect of low water levels. Concentrations of nutrient and trace elements in all water samples were below wildlife toxicity thresholds as established by Arizona Department of Environmental Quality. Three nonnative species were discovered shortly after the Fire Break Canal went into operation. Of the three, gizzard shad (Dorosoma cepedianum) and Eurasian watermilfoil (Myriophyllum spicatum) increased substantially in numbers from 2011-14, but quagga mussels (Dreissena bugensis) did not increase. Future monitoring will determine the long-term impact of the new flow regime.

\section{Introduction}

The marshes and other wetland areas of Topock Marsh within the Havasu National Wildlife Refuge (NWR) were created and maintained by the dynamic flows of the Colorado River before construction of major dams and diversions. Throughout the 20th century, the river was regulated through a series of water development projects that changed the flow dynamics and reduced the frequency and magnitude of floods and droughts that characterized the unregulated river (U.S. Department of the Interior [DOI], 2009). Under the regulated flow regime, many fish and wildlife species that were adapted to the natural conditions became threatened, endangered, or of special concern to Federal and State resource management agencies (DOI, 2009). 
In 1941, Executive Order 8647 was issued by President Franklin Roosevelt to establish Havasu NWR for use by the Department of the Interior as a refuge and breeding ground for migratory birds and other wildlife (6 Federal Register 593; January 25, 1941) (Roosevelt, 1941). During the years since then, various canals, dikes, and ditches were constructed (fig. 1) to help maintain the marsh's original function (U.S. Fish and Wildlife Service, 1966; Shoreline Engineering and Restoration, 2006). A more complete chronology of the history of the marsh and its hydrology is presented in Guay (2001). To address the deterioration of the water management infrastructure and changes in the physical characteristics and management of the Colorado River, the U.S. Fish and Wildlife Service (FWS) initiated an infrastructure improvement project in cooperation with the Bureau of Reclamation. The project was designed to enable managers to better control water levels in an effort to protect and improve the current habitat for species of special interest and special status (threatened, endangered, or candidate species), as well as habitats for common species that use the Havasu NWR (DOI, 2009). During construction of the new infrastructure, inflows into Topock Marsh were maintained at lower than usual levels (fig. $2 A$ ), which resulted in below-average water depths throughout 2011, as measured as water elevations at the outlet structure in the South Dike (fig. 2B). Consequently, the FWS commissioned assistance from the U.S. Geological Survey (USGS) to assess the aquatic biotic and abiotic condition of the marsh during these unusually low water levels.

In addition to measuring water-quality conditions and comparing them to previous water-quality data collected by Reclamation, the assessment was conducted to learn how the aquatic flora and fauna responded to the low water conditions and, subsequently, how hydrologic manipulation by means of the new infrastructure could affect ecological management and restoration. Habitats specifically identified for species protection within the marsh include those that support the fully protected and threatened black rail (Laterallus jamaicensis coturniculus), the endangered Ridgway's rail (Rallus obsoletus yumanensis, formerly Yuma clapper rail), Southwestern willow flycatcher (Empidonax traillii extimus), and razorback sucker (Xyrauchen texanus), as well as other species listed in the draft environmental assessment for the Topock Marsh water infrastructure improvement project (DOI, 2009). Therefore, sampling efforts were focused on monitoring representative areas that would potentially be used by these species.

In addition to USGS's water quality and aquatic flora and fauna monitoring of Topock Marsh during low water conditions and immediately after higher flow was restored, FWS needed to better understand the health and function of Topock Marsh under various hydrologic conditions. With funding provided by the FWS Desert Landscape Conservation Cooperative, USGS developed a decision support system (DSS) using a spatially explicit geographic information system package of historical data, habitat indices, and analytical tools to synthesize outputs for varying hydrologic conditions.
The first phase of the Havasu NWR DSS, called Phase 1 (hindcasting model), was developed to be used by the refuge managers to compare habitat availability associated with three historical hydrologic scenarios (historical dry, average, wet years) along with additional proposed operations of interest by specifying a range of marsh water surface elevations (WSEs) throughout the year (Holmquist-Johnson and others, 2016). Phase 1 of the DSS does not explicitly model the quantity of water delivered from the Colorado River through the various canals to the marsh that is required to meet a given marsh elevation. Instead, a hindcasting-type analysis is used to determine the total volume of water that must be added or subtracted throughout the year to meet a prescribed range of marsh elevations. The total volume of water required to meet a given hydrologic scenario can then be used by refuge managers, along with Reclamation engineers, to determine the availability of Colorado River water and the most efficient method of delivering water to the marsh. A detailed description of the types of outputs that are available from the Phase 1 DSS can be found in Holmquist-Johnson and others (2016). A number of predefined views are available that provide a starting point for users in analyzing the effects of marsh elevations on available habitat and water storage and inflow requirements at Topock Marsh. For example, the "habitat versus water surface elevation curves" view provides a summary plot of suitable habitat using the habitat suitability criteria described by Bovee (1986) for a given species and life stage as a function of marsh elevation. Additionally, the "summary habitat results - all scenarios" view provides a bar chart showing the mean annual available habitat for six species within each management scenario compared to the historical average baseline.

Although the DSS does not produce any specific biological output (that is, clutch size, plant growth, or juvenile survival), it does provide a tool to identify relative effects of water operations on ecological processes and species-specific habitats that can be used by Havasu NWR staff and managers. The DSS also provides the data discussed in this report as additional information for the user to assist them in determining what might happen under various scenarios based on historical conditions and trends. The adaptability of the DSS tool as time goes on is one of the DSS's most valuable capabilities. To continue to improve on the work that has been conducted at Topock Marsh, USGS, FWS, Reclamation, and other science partners could continue to collaborate and work towards developing a Phase 2 (forecasting model) of the Havasu NWR DSS. This Phase 2 DSS would build on the current Phase 1 hindcasting model DSS and would incorporate output from water management operations and hydrodynamic (water quantity and quality) modeling based on marsh bathymetry, Colorado River hydrology, and future water delivery methods. The data presented in this report could be used to provide vital information in calibration and validation of a water-quality model for Topock Marsh. The output from the water-quality model could then be used by the Phase 2 DSS as inputs to assess how various marsh scenarios might affect the water-quality conditions throughout the marsh. Synthesis of 


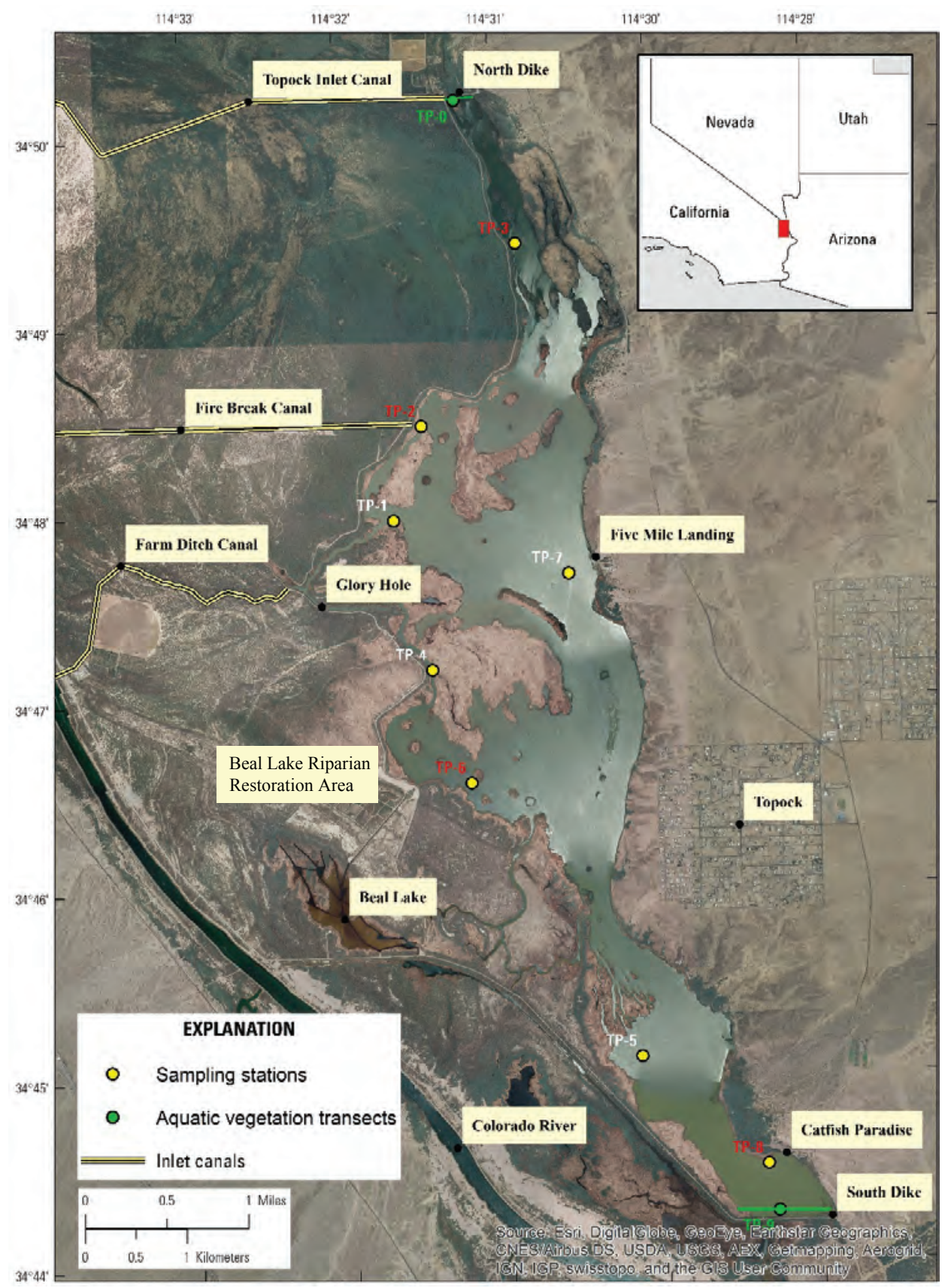

Figure 1. Location of 3 water irrigation canals (Topock Inlet, Fire Break, and Farm Ditch) and 10 biotic and abiotic sampling stations within Topock Marsh, Arizona. The sampling stations are denoted as TP-0 through TP-9. Four sampling stations shown in red (TP-3, TP-2, TP-6, and TP-8) are 2011-14 U.S. Geological Survey sample collection locations. Aquatic vegetation data were collected along two transects, TP-0 and TP-9 (shown as green lines). 


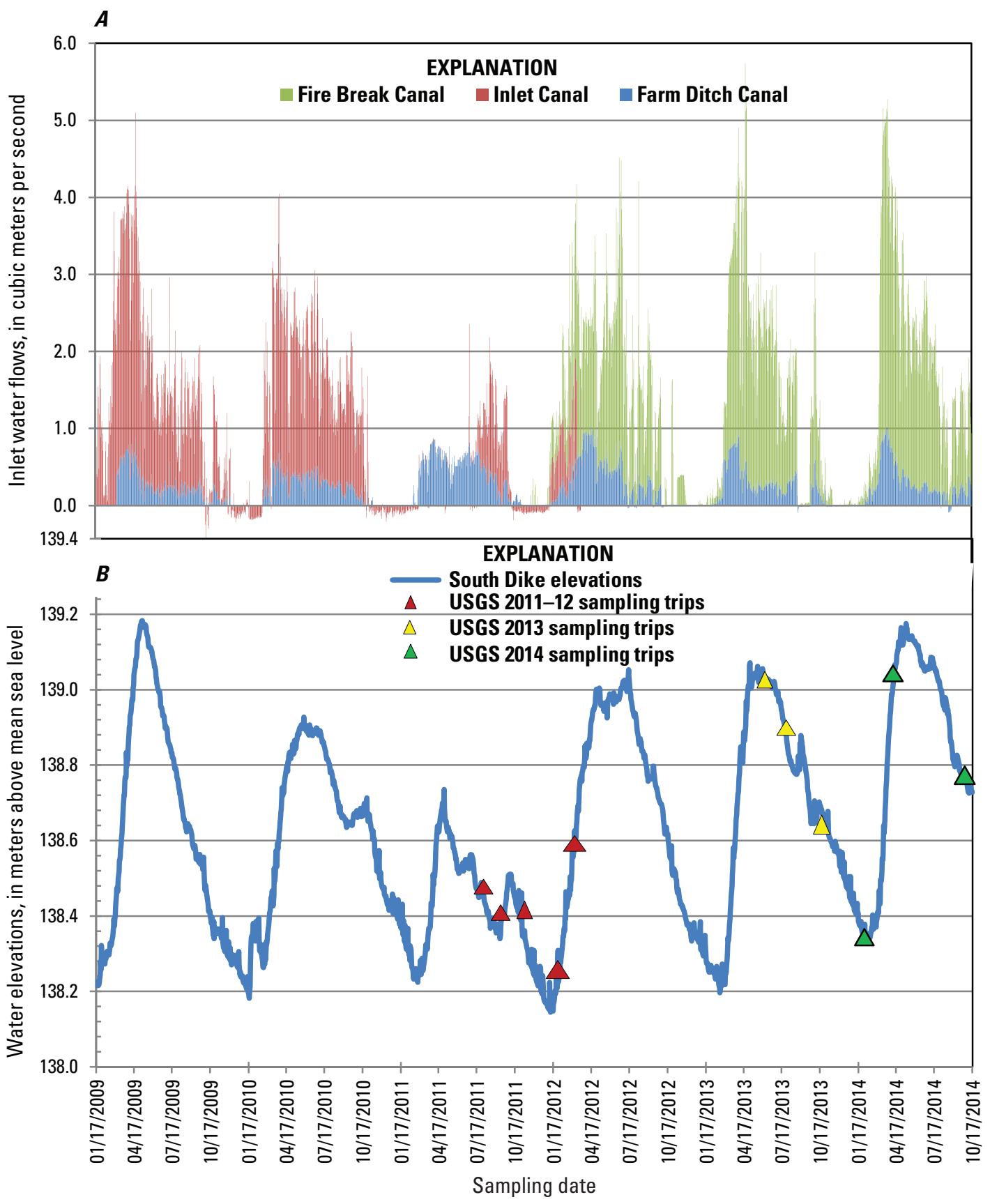

Figure 2. Topock Marsh, Arizona, inlet flows and water elevations at the South Dike from January 2009 to October 2014. A, Topock Marsh inlet flows and B, water elevations at the South Dike. (USGS, U.S. Geological Survey) 
these additional model outputs would allow FWS to compare different hydrologic scenarios, water management operations and delivery methods, and their influences on species-specific habitat. Once these tools are developed, they could be valuable for, and directly applicable to, future analysis needs that could include indepth evaluation of climate change effects.

In summary, the specific objectives of the data reported herein were to 1) determine the status of the marsh during the 2011 low waterflow period, 2) assess whether use of the new Fire Break Canal and closing of the Inlet Canal in 2012 impacted the water quality and (or) aquatic biota in the marsh compared to previous years, and 3) provide 2011-14 water-quality and aquatic flora and fauna data as additional information to the DSS user to assist them in determining what might happen under various scenarios based on historical conditions and trends.

\section{Site Description}

Topock Marsh is located in the Mojave Desert adjacent to, and on the east side of, the Colorado River between Needles, California, and Lake Havasu City, Arizona (fig. 1). The marsh is approximately 16 kilometers $(\mathrm{km})(9.9$ miles [mi]) long and $3 \mathrm{~km}(1.9 \mathrm{mi})$ wide at its widest point and the surface area of the wetland is 1,637 hectares (4,045 acres) (Guay, 2001). The Colorado River is regulated by Davis Dam, which is located approximately $64 \mathrm{~km}(39.8 \mathrm{mi}$.) upstream of the marsh. Colorado River water is delivered through the earthen Farm Ditch Canal, which was built in 1968 on the marsh's west side, and the Fire Break Canal, which was completed in September 2011 and has operated consistently since January 2012 (figs. 1 and 2). Inflow from the Inlet Canal (figs. 1 and 2A), which was built in 1965 at the marsh's northern end, was closed off in March 2012 primarily because of the large water loss through the $6.6 \mathrm{~km}$ (4.1 mi.) earthen canal and mixed land ownership issues (DOI, 2009).

Historically, all water flowed into the marsh by gravity feed and moved from north to south parallel to the Colorado River. The infrastructure was built to allow the marsh to drain through an outlet structure in the South Dike, which was built in 1965. Little to no outflow occurred during the July 2011-October 2014 USGS sampling period, as shown by the Reclamation's water gage data available at http://www.usbr.gov/lc/region/g4000/ riverdata/gage-map3-text.cfm.

However, there was some waterflow that came into the marsh through the South Dike, which is normally used as the outflow, so it registered as negative flow numbers (fig. $2 A$ ).

Weather at Topock Marsh is typically hot and dry during the summer months (June, July, and August). The maximum air temperature reached 50.6 degrees Celsius $\left({ }^{\circ} \mathrm{C}\right)(123$ degrees Fahrenheit $\left[{ }^{\circ} \mathrm{F}\right]$ ) on June 29, 2013 between the two summer 2013 sampling trips and total precipitation was 0.28 centimeters $(\mathrm{cm})(0.11$ inches [in.]) during that time. The minimum air temperature recorded was $-2.2{ }^{\circ} \mathrm{C}\left(28.0^{\circ} \mathrm{F}\right)$ in January 2013 , but the mean annual low temperature was $18.3^{\circ} \mathrm{C}\left(64.9^{\circ} \mathrm{F}\right)$ (fig. $3 A$ ). The prevailing winds are typically from the north and northwest during winter months (December, January, and February) and from the south and southwest during the summer months. The maximum wind gust during the study period occurred in July 2014 and was $114.3 \mathrm{~km}$ per hour $(\mathrm{km} / \mathrm{h})$ (71.0 miles per hour [mi/h]) (fig. $3 B$ ). The maximum monthly precipitation during the study period was $7.24 \mathrm{~cm}$ (2.85 in.) in August 2013; no monthly precipitation was recorded during January, May, June, and November 2012; April, May, and June 2013; and January, March, May, and June 2014 (National Oceanic and Atmospheric Administration, 2016; Weather Underground, 2016; WeatherSpark Beta, 2016).

\section{Methods}

\section{Sampling Schedule and Waterflow Data Records}

Eleven individual sampling events were conducted between July 25, 2011, and October 7, 2014, and additional in situ physicochemistry measurements were collected during December 2013. These events are marked on figure $2 B$. Specific sampling activities are listed in tables 1 and 2. Dates of sampling trips; WSEs, as measured at the outlet structure in the South Dike; and waterflow rates are listed in table 3. During this study period, the WSEs ranged from 138.14 meters $(\mathrm{m})$ (453.22 feet [ft]) above mean sea level (amsl) on January 10, 2012, to $139.18 \mathrm{~m}$ (456.63 ft) amsl on May 11, 2014. Waterflow through the Farm Ditch Canal, Inlet Canal, and the South Dike and WSE data were obtained from Reclamation gage data (http://www.usbr.gov/lc/ region/g4000/riverdata/gage-map3-text.cfm) and verified by Reclamation personnel. Flow rates for the Fire Break Canal were obtained from USGS gage data (U.S. Geological Survey, 2016a, http:/nwis.waterdata.usgs.gov/nwis/inventory/

?site_no=09423560\&agency_cd=USGS). Total flows into the marsh and WSEs at the South Dike outlet structure are shown in figures $2 A$ and $2 B$ for the period January 2009-October 2014.

\section{Sample Locations}

Four sampling stations were selected within the marsh along the upstream to downstream gradient: TP-3, TP-2, TP-6 and TP-8 (see fig. 1). These sampling stations, which were all accessible by boat, were selected from eight sites previously selected by FWS biologists to characterize various habitat types along the marsh shoreline from inlet to outlet from the Arizona Fish and Wildlife Conservation Office (AZFWCO) in Parker, Arizona. Station TP-3 is the most northern of the sampling stations and closest to the Inlet Canal. TP-2 is located where the flow from the Fire Break Canal enters the marsh. TP-6 is along the western edge of the marsh near the Beal Lake Riparian Restoration Area. TP-8 is the southernmost sampling station and is located $195 \mathrm{~m}(640 \mathrm{ft})$ northwest of the Catfish Paradise boat launch and directly north and upstream of the South Dike outlet. 

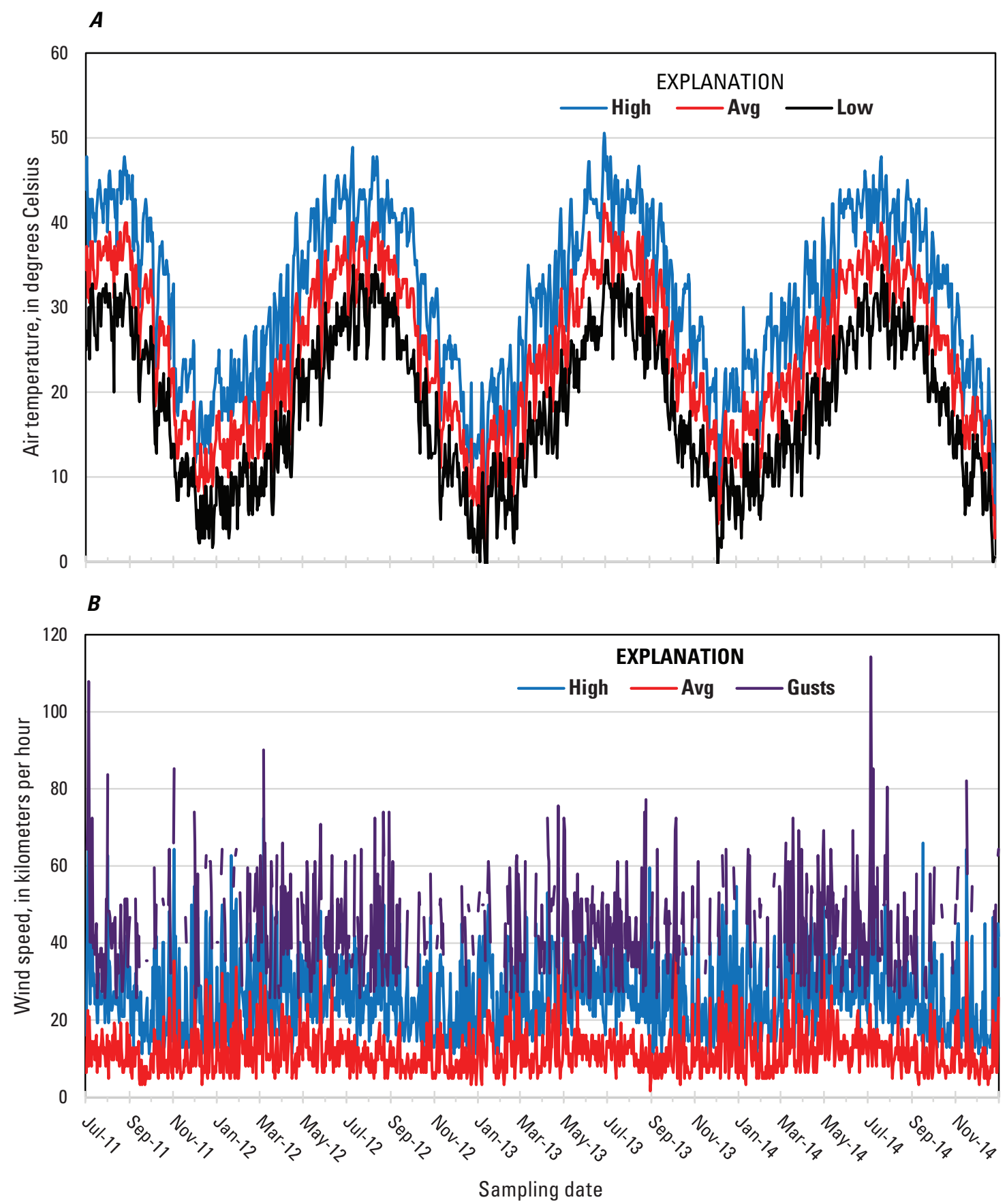

Figure 3. Air temperature $(A)$ and wind speed $(B)$ recorded at the Needles Airport, California, weather station (National Oceanic and Atmospheric Administration, 2016) from July 1, 2011 to December 31, 2014. 
Table 1. Parameters and specific data sampled within Topock Marsh from July 2011 to October 2014.

[SC, specific conductance; DO, dissolved oxygen; $\mathrm{NH}_{3}-\mathrm{N}$, ammonia-nitrogen; $\mathrm{NO}_{3}$, nitrate; $\mathrm{NO}_{2}-\mathrm{N}$, nitrite nitrogen; Org-N, organic nitrogen; TN, total nitrogen; TP, total phosphorus; TSS, total suspended solids; SS, volatile-on-ignition suspended solids; As, arsenic; B, boron; Ca, calcium; $\mathrm{Cd}$, cadmium; $\mathrm{Cl}$, chlorine; Cr, chromium; $\mathrm{Cu}$, copper; F; fluoride; Fe, iron; $\mathrm{Hg}$, mercury; K, potassium; Mg, magnesium; Mn, manganese; $\mathrm{Na}$, sodium; Pb, lead; Se, selenium; $\mathrm{Zn}$, zinc; $\mathrm{SO}$, sulfate; TDS, total dissolved solids; $\mathrm{CO}_{3}$, carbonate; $\mathrm{HCO}_{3}$, bicarbonate; $\mathrm{CaCO}_{3}$, calcium carbonate; $\mathrm{SiO}_{2}$, silicon dioxide; $\mathrm{EC}$, electrical conductivity; \%, percentage; OM, organic matter; $\mathrm{NO}_{3}-\mathrm{N}$, nitrate-nitrogen; P, phosphorus; $\mathrm{S}$, sulfur; Mo, molybdenum; N, nitrogen; Al, aluminum; sUAS, small unmanned aircraft system]

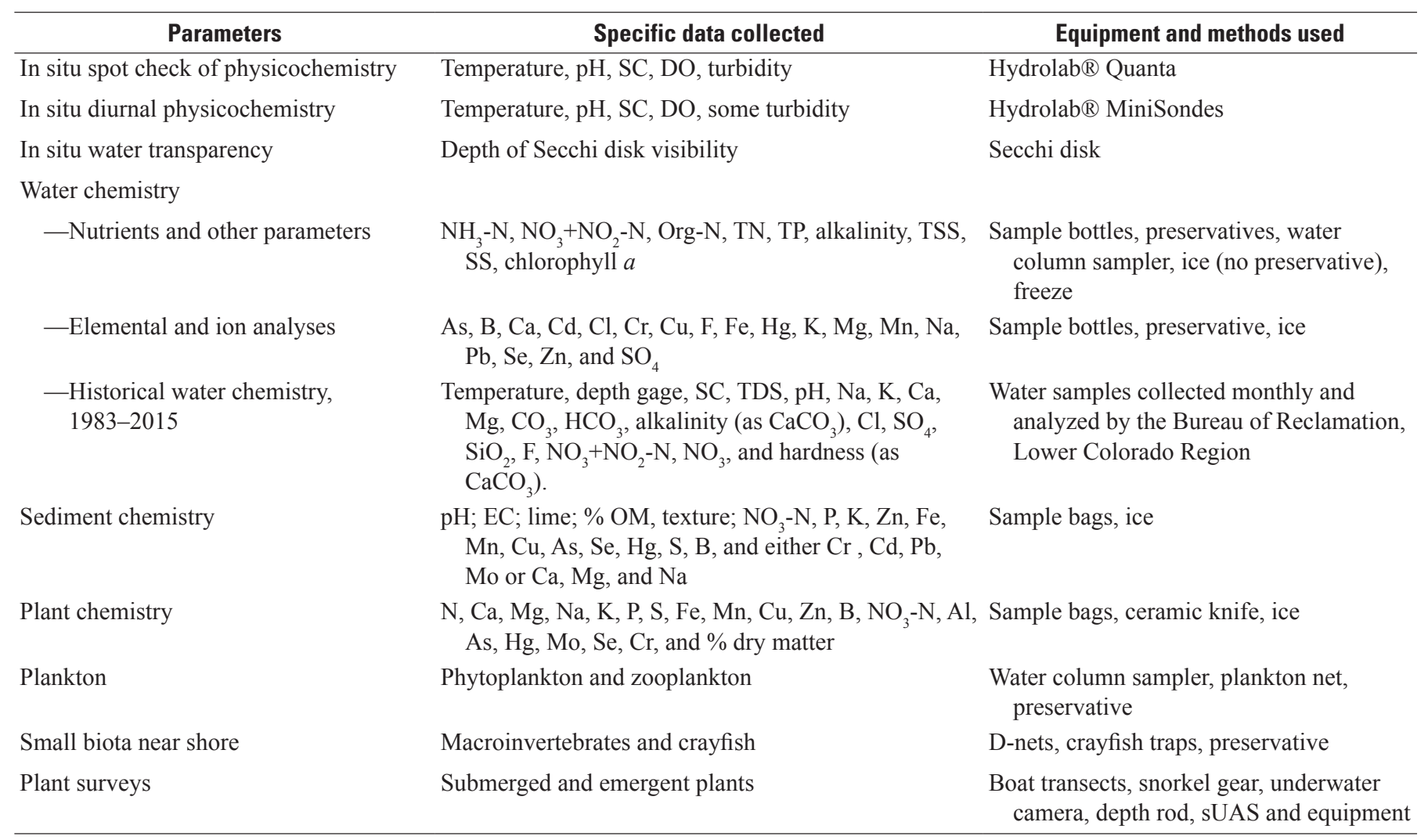

\section{Water-Quality Characteristics- Protocol and Equipment}

\section{Physicochemistry}

Vertical profiles of physicochemical parameters were collected at the four sampling stations using an instantaneous in situ instrument (Hydrolab ${ }^{\circledR}$ Quanta) that was calibrated before each sampling trip. The Hydrolab ${ }^{\circledR}$ Quanta measured water temperature in ${ }^{\circ} \mathrm{C}, \mathrm{pH}$ in standard units, dissolved oxygen (DO) in milligrams per liter $(\mathrm{mg} / \mathrm{L})$, specific conductance (SC) in microsiemens per centimeter $\left(\mu \mathrm{S} / \mathrm{cm}\right.$ at $\left.25^{\circ} \mathrm{C}\right)$, total dissolved solids (TDS) in $\mathrm{mg} / \mathrm{L}$, and turbidity in nephelometric turbidity units (NTUs). The vertical profile consisted of measurements taken at $0.05-0.10 \mathrm{~m}(2.0-3.9 \mathrm{in}$.) below the water surface and at $0.5 \mathrm{~m}$ (1.6 ft) increments to just above the sediment floor (marsh bottom). During 2013-14, measurements were also taken at $0.2 \mathrm{~m}$ (7.9 in.) (or $0.3 \mathrm{~m}$ [11.8 in.] in April 2014) below the surface at sites with water depths of $\leq 1.0 \mathrm{~m}(\leq 3.3 \mathrm{ft})$. Extreme values for DO and turbidity were caused by sediment disturbance by the instrument as it accidently contacted the soft marsh bottom. When this occurred and there was a more than 45 NTU increase from the previous value, those values were not included on the figures. Water clarity was estimated using a Secchi disk; the Secchi depth, measured to the nearest $0.01 \mathrm{~m}$ (2 in.) at the time of vertical profile sampling, was compared to turbidity measurements for an inverse verification (that is to say, a higher Secchi depth relates inversely to a lower turbidity value). Turbidity is a measure of water clarity as it relates to how much the material suspended in the water decreases the passage of light through the water. Suspended materials include soil particles (clay, silt, and sand), algae, plankton, microbes, and other substances (Kadlec and Wallace, 2009).

Freshly calibrated datalogging multiparameter instruments (Hydrolab ${ }^{\circledR}$ MiniSonde 4a and 5a) were deployed at the four sample stations during each sampling trip (table 2) to measure diurnal physicochemistry. Each of the units was programmed to record water temperature, $\mathrm{pH}, \mathrm{DO}, \mathrm{SC}$, salinity, and TDS at hourly intervals. In 2013, two MiniSonde 5 as were outfitted and deployed with turbidity probes set to measure and record hourly, and those data were used to compare to the Quanta turbidity measurements and to Secchi disk readings. Deployment periods varied by the number of days we were in the field (2.5-8 consecutive days). The MiniSondes were secured at mid-water column depths either to sampling station buoys, large cinder blocks anchored to the marsh bottom, or the nearest tree snag. 
Table 2. Dates, analyses, and locations where the various samples were taken in Topock Marsh from July 2011 through October 2014.

[TP, sampling station; Jl, July; S, September; O1', October 2011; JF, January/February; M, March; Jn, June; O³, October 2013, D, December; F, February; Ap, April; O4, October 2014; typ., typically; AGFD, Arizona Game and Fish Department]

\section{Data collected}

In situ spot check of physiochemistry In situ diurnal physiochemistry

+ including diurnal turbidity

In situ water transparency

Water chemistry

Nutrients and other parameters

Elemental analyses, ions

Sediment chemistry

Plant chemistry

Chlorophyll $a$

Plankton

Phytoplankton

Zooplankton

Small biota near shore

Macroinvertebrates

Crayfish

Plant surveys

Submerged (typ. along TP-3, 2, 1, 6, or 8)

Emergent-aerial survey

Fish surveys

Gill nets - with AGFD

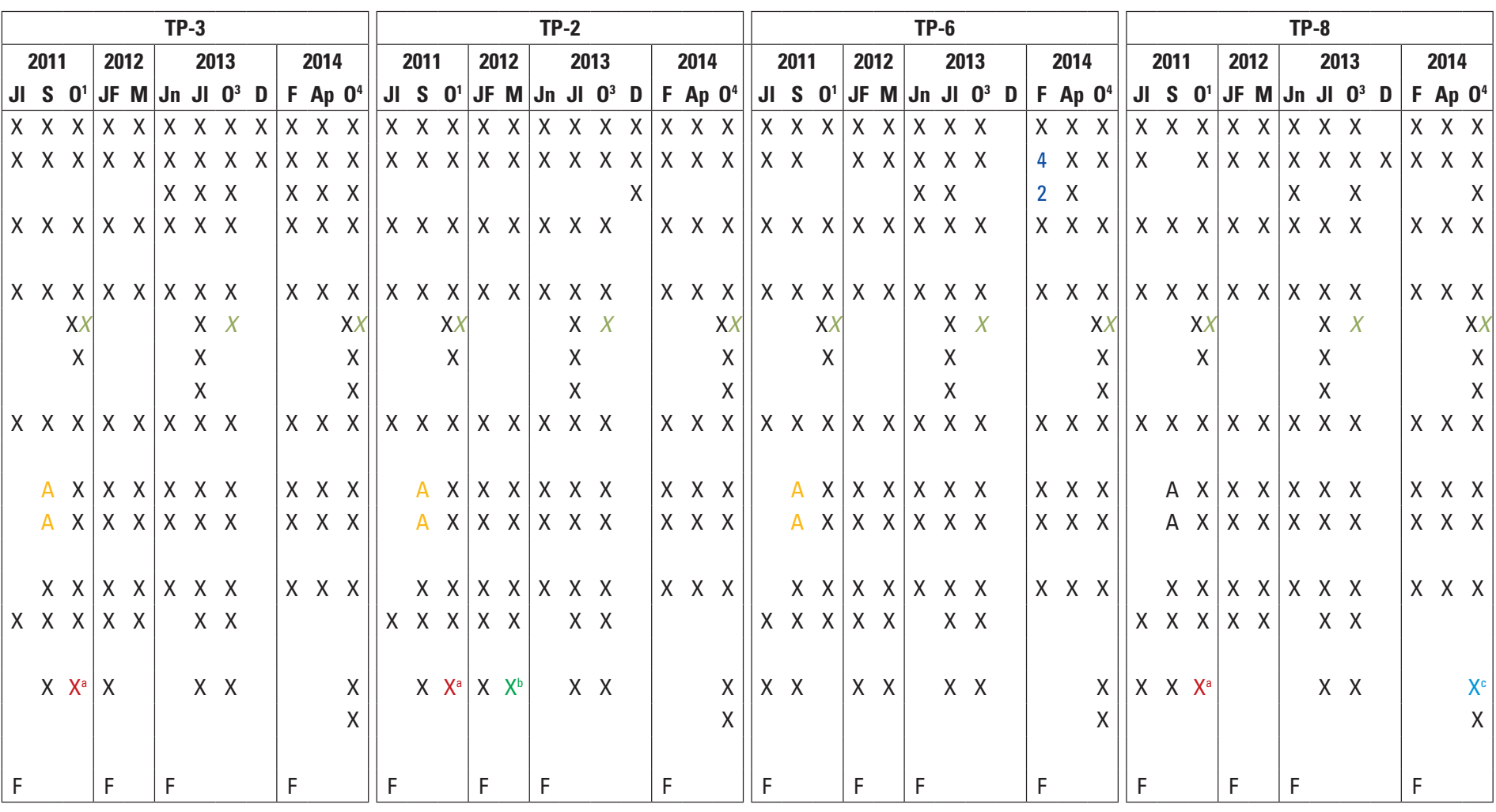

Notes:

$A=$ August collection

$X=$ ion analyses

$\mathrm{F}=$ February collections
$\mathrm{X}^{\mathrm{a}}=$ surveys taken along TP-0, TP-1, and TP-9, instead $X^{b}=$ surveys also taken along TP-5

$\mathrm{X}^{\mathrm{c}}=$ survey also taken along TP-9
$4=$ only four hours of data storage

$2=$ only two hours of data storage 
Table 3. Topock Marsh average water surface elevations and average waterflow rates during each biotic and abiotic sampling trip from July 2011 through October 2014.

[Water surface elevations and flow rates were published online by the Bureau of Reclamation and subsequently averaged by the U.S. Geological Survey for each sampling period. WSE, water surface elevation; WFR, waterflow rate; m, meter; amsl, above mean sea level; $\mathrm{ft}$, foot; $\mathrm{m}^{3} / \mathrm{s}$, cubic meter per second; $\mathrm{ft}^{3} / \mathrm{s}$, cubic foot per second]

\begin{tabular}{llccr}
\hline \multicolumn{1}{c}{ Sampling dates } & $\begin{array}{c}\text { WSE } \\
\mathbf{m} \text { amsI }\end{array}$ & $\begin{array}{c}\text { WSE } \\
\mathbf{f t} \text { ams }\end{array}$ & $\begin{array}{c}\text { WFR } \\
\mathbf{m}^{3} / \mathbf{s}\end{array}$ & $\begin{array}{c}\text { WFR } \\
\mathbf{f t}^{3} / \mathbf{s}\end{array}$ \\
\hline July 25-29, 2011 & 138.48 & 454.33 & 2.107 & 74.400 \\
September 21-23, 2011 & 138.41 & 454.10 & 1.044 & 36.867 \\
October 23-27, 2011 & 138.43 & 454.16 & 0.039 & 1.380 \\
January 30-February 2, 2012 & 138.25 & 453.58 & 0.968 & 34.196 \\
March 6-9, 2012 & 138.60 & 454.73 & 2.284 & 80.670 \\
June 10-14, 2013 & 139.03 & 456.12 & 2.478 & 87.520 \\
July 21-25, 2013 & 138.91 & 455.73 & 1.135 & 40.080 \\
October 28-31, 2013 & 138.64 & 454.86 & 0.348 & 12.300 \\
December 12-18, 2013* & 138.50 & 454.41 & 0.006 & 0.200 \\
February 10-14, 2014 & 138.35 & 453.89 & 0.266 & 9.398 \\
April 14-22, 2014 & 139.08 & 456.30 & 3.516 & 124.175 \\
September 29-October 7, 2014 & 138.75 & 455.23 & 0.888 & 31.368 \\
\hline
\end{tabular}

*Only in situ water quality monitoring at TP-3 and TP-2 occurred during this trip.

\section{Chlorophyll a, Nutrients, Major lons, and Trace Elements}

Water samples for determining chlorophyll $a$ content were obtained during each of the 11 sampling trips. The entire water column was sampled with a weighted flexible pool hose, as described in Lieberman and Grabowski (2007). The water column sample was mixed in a clean bucket and divided into two parts for separate chlorophyll $a$ and phytoplankton analyses (see the "Phytoplankton and Zooplankton" section of this report for additional information). Each chlorophyll $a$ sample was filtered onto a 47 -millimeter (1.85 in.) glass-fiber/circle filter, with a particle retention of 1.2 micrometers $(\mu \mathrm{m})(0.000047 \mathrm{in}$.), and kept frozen and in the dark until analysis. Chlorophyll $a$ analyses were performed by Reclamation's Lower Colorado (LC) Regional Laboratory in July and September 2011, and by Reclamation's Water and Environmental Resources Division Environmental Applications \& Research Laboratory the other nine times, according to standard methods described in American Public Health Department and others (1995).

Water samples for all other analyses were collected from just under the water surface at the 4 sampling stations during each of the 11 sampling trips. Total suspended solids (TSS); alkalinity, as calcium carbonate; total phosphorus (TP); total Kjeldahl nitrogen, which is ammonia $\left(\mathrm{NH}_{3)}+\right.$ organic nitrogen $(\mathrm{Org}-\mathrm{N})$; ammonianitrogen $\left(\mathrm{NH}_{3}-\mathrm{N}\right)$; and total nitrogen $(\mathrm{TN})$ (table 1) were analyzed for each sampling trip, except that TSS and alkalinity were not analyzed for July 2013. Organic nitrogen was calculated by subtracting $\mathrm{NH}_{3}-\mathrm{N}$ from total Kjeldahl nitrogen. Nitrate + nitrite nitrogen $\left(\mathrm{NO}_{3}+\mathrm{NO}_{2}-\mathrm{N}\right)$ values were calculated by subtracting total Kjeldahl nitrogen from TN. Water samples collected in 2011 were prepared and preserved for analysis by Reclamation's
LC Regional Laboratory in Boulder City, Nevada, according to standard operating procedures as described by Eaton and others (2005). All water samples collected in 2012, 2013, and 2014 were analyzed by the USGS National Water Quality Laboratory in Denver, Colorado, according to USGS published methods, which are available at http://nwql.usgs.gov/rpt.shtml?pubs (U.S. Geological Survey, 2016b).

Additional surface water samples were collected in October 2011, July 2013, and October 2014 for the following elemental analyses: arsenic (As), boron (B), cadmium, chromium $(\mathrm{Cr})$, copper $(\mathrm{Cu})$, fluoride, iron $(\mathrm{Fe})$, mercury $(\mathrm{Hg})$, manganese (Mn), lead, selenium (Se), and zinc (tables 1 and 2). October 2011, October 2013, and October 2014 samples were also analyzed for the major ions calcium, chlorine, magnesium, potassium (K), sodium, and sulfate so the ions could be included on Stiff diagrams. Water samples collected in 2011 were prepared and preserved for analysis by Reclamation's LC Regional Laboratory in Boulder City, Nevada, according to standard operating procedures (Eaton and others, 2005). All water samples collected in 2013 and 2014 were preserved and shipped to the National Water Quality Laboratory for analysis according to their published methods, which are available at http://nwql.usgs.gov/ rpt.shtml?pubs (U.S. Geological Survey, 2016b).

\section{Long-Term Water Chemistry}

Historically, Reclamation has collected quarterly or monthly water samples from the upstream side of the South Dike outlet gate structure using their standard operating procedures (Bureau of Reclamation, 2009). The samples were subsequently analyzed by Reclamation's LC Regional Laboratory for the following parameters: SC, TDS, $\mathrm{pH}$, sodium, $\mathrm{K}$, 
calcium, magnesium, carbonate, bicarbonate, alkalinity (as calcium carbonate), chlorine, sulfate, silicon dioxide, fluoride, $\mathrm{NO}_{3}+\mathrm{NO}_{2}-\mathrm{N}$, nitrate, and hardness (as calcium carbonate) (app. 1). Data from late 1983 to April 2015 were provided by Reclamation (Janet Kirsch, written commun., 2015). Reclamation has not historically collected biological data on aquatic flora and fauna within Topock Marsh.

\section{Sediment Chemistry}

Sediment samples were collected in October 2011, July 2013, and October 2014 at each sampling station by hand using powder-free latex gloves. The samples were placed in labeled Ziploc plastic bags, kept on ice, and later refrigerated until analysis (tables 1 and 2). Sediment samples were analyzed by the Colorado State University's (CSU's) Soil, Water and Plant Testing Laboratory in Fort Collins, Colorado, according to standard procedures (Gee and Bauder, 1986; Workman and others, 1988; U.S. Department of Agriculture, 1996). Analyses included routine soil testing of $\mathrm{pH}$; electrical conductivity; lime estimate; percentages of organic matter, sand, silt and clay; plant available nutrients (nitrate-nitrogen $\left[\mathrm{NO}_{3}-\mathrm{N}\right]$, phosphorus, $\mathrm{K}$, zinc, $\mathrm{Fe}, \mathrm{Mn}$, and $\mathrm{Cu}$ ); and four elements of concern (As, $\mathrm{Se}, \mathrm{Hg}$, and hexavalent $\mathrm{Cr}$ ).

\section{Plant Chemistry}

Plant samples were collected from each sampling station in July 2013 and October 2014 using ceramic knives and powderfree latex gloves. In addition, a replicate sample was collected at TP-6 in July 2013 and a sample was collected along the South Dike (TP-9) in October 2014. The goal was to test for the nutrient value and the chemical composition of the plants to see if the chemicals in the plants were at potentially toxic levels to wildlife. Submerged aquatic vegetation (SAV) was targeted because of its value as food to waterfowl. Each plant sample, which included above- and below-ground material, was placed in labeled Ziploc plastic bags, kept on ice, and then refrigerated until analysis (tables 1 and 2). Plant samples were analyzed by CSU's Soil, Water and Plant Testing Laboratory in Fort Collins, Colorado, according to standard procedures (U.S. Environmental Protection Agency, 1986b; Miller and Kotuby-Amacher, 1994). The analyses included routine testing for nitrogen, $\mathrm{NO}_{3}-\mathrm{N}$, calcium, magnesium, sodium, $\mathrm{K}$, phosphorus, sulfur, $\mathrm{Fe}, \mathrm{Mn}, \mathrm{Cu}$, zinc, $\mathrm{B}$, molybdenum, aluminum, percent dry matter and four elements of concern (As, Se, $\mathrm{Hg}$, and $\mathrm{Cr}$ ). Owing to the scarcity of SAV in July 2013, all of the plants collected for that sampling period were emergent California bulrush (Schoenoplectus californicus). In October 2014, however, SAV was abundant, so four spiny naiad (Najas marina) samples and one Eurasian watermilfoil (Myriophyllum spicatum) sample were collected for chemical analyses because of their higher value to waterfowl. For consistency, we would have liked to have collected California bulrush as we did in July 2013 but, because of higher water depths, California bulrush was not sampled during October 2014. All October 2014 samples were analyzed for the same elements as the July 2013 samples with the exclusion of $\mathrm{Cr}$. The $\mathrm{Cr}$ analysis was discontinued because of the low values measured in the 2013 samples and to reduce analyses costs.

\section{Biological Characteristics- Protocol and Equipment}

\section{Aquatic Vegetation}

SAV coverage within Topock Marsh was quantified by establishing transects that ran west to east in association with the sampling stations. Techniques were devised during our first sampling trip (July 2011) and all subsequent SAV transects were conducted with the assistance of AZFWCO or Havasu NWR staff.

A 6-m (20-ft) Jon boat powered by an outboard motor was used in surveying the transects, and a black and white underwater camera was used to detect plants when none could be seen from the water surface because of turbidity or water depth. The camera, hung off the side of the boat and held near the marsh floor by the cable, was turned 360 degrees at each sample point along each transect to look for vegetation, and the picture of the marsh floor was displayed on the video screen on the boat. When visual inspections were impossible to make from the boat or with the underwater camera, a weed rake was thrown from the boat 3 times and dragged along the marsh floor for approximately 10 seconds at random intervals (approximately every 31-61 m (102-200 ft) or as fast as data could be recorded before taking the next sample) at idle speed (speed that would not generate a wake, which is from 600 to 800 engine revolutions per minute) to spot check for any possible vegetation. Turbidity and water depths were measured at the same points along the transects during these surveys to provide information on the conditions to which the aquatic vegetation was being exposed. Coverage by species was estimated at each sample point as the proportion of live vegetation growing from an approximate 1-square meter (10.8-square foot) bottom area and was recorded as coverage ratings of 0,1 , 2 , and 3 , where $0=$ no vegetation, $1=<30$ percent (low) vegetation coverage, $2=30-<70$ percent (moderate) coverage, and $3=70-100$ percent (high) coverage. Transects were evaluated during September and October 2011, January/February 2012, July and October 2013, and October 2014 (table 2).

The four coverage ratings for SAV were plotted in relation to the turbidity measured at $0.2 \mathrm{~m}$ (7.9 in.) below the water surface ("surface turbidity") and the water column depth at each observation point along the transects. We used October data (when SAV was at maximum levels) to examine the relationship between SAV coverage ratings and surface turbidity and water depth, using one-way analysis of variance (ANOVA) analysis. Tukey's Honest Significant Difference Test was used to examine pairwise comparisons (Neter and others, 1996) and Akaike's Information Criteria (Sakamoto and others, 1986) were examined to determine the best model.

The emergent aquatic vegetation coverage in Topock Marsh was quantified in 2014 as part of the FWS Desert Landscape Conservation Cooperative project and referred to 
as Tier 2 in that proposal. A total of 6,683 global positioning system (GPS) points capturing the various land cover classes located primarily along the marsh edge were collected and recorded using georeferenced survey-grade Trimble GPS units. Vegetation composition and respective canopy cover were estimated for the immediate area surrounding each point (approximately a $2-\mathrm{m}[6.6 \mathrm{ft}]$ radius circle around the center), including open water and SAV-covered areas. Those data collected along with the bathymetry data (Tier 3) in December 2013 and April 2014 were used with World View-2 imaging, captured on July 22, 2014, and October 11, 2014, to create a land-cover classification model of the vegetation of Topock Marsh.

The specific vegetation composition data recorded on the Trimble GPS units were used to "train" a model to determine land area covered by specific plant species. The development of the model by students and staff at CSU's Resource Ecology Laboratory to predict the area covered by emergent vegetation is described in detail in their report (Young and others, 2015) and is discussed thoroughly in the Tier 2 section of the final DSS report (Holmquist-Johnson and others, 2016). Because we did not expect the World View-2 imaging to "see" into the water, our goal initially was to determine only those areas covered by emergent vegetation. However, when evidence of what looked like SAV was seen in the images over open water, the CSU team also attempted to model the SAV-covered areas. In addition to the data collected for the modelling effort, field observations of the aquatic vegetation were recorded to document other conditions that were considered to be ecologically noteworthy.

\section{Phytoplankton and Zooplankton}

Phytoplankton samples were collected at each sampling station during most sampling trips (tables 1 and 2). The entire water column was sampled (see the "Chlorophyll $a$, Nutrients, Major Ions, and Trace Elements" section of this report for information on collection techniques). Unfiltered phytoplankton samples were preserved with a 2 percent Lugol's solution and identified and enumerated by BSA Environmental Services, Inc. (Beachwood, Ohio). Phytoplankton data for each taxonomic group were reported as total biovolume in cubic micrometers per milliliter $\left(\mu \mathrm{m}^{3} / \mathrm{mL}\right)$ and cell density in number of cells per milliliter. Biovolume was estimated using the formula for solid geometric shapes that most closely match the cell shape (Hillebrand and others, 1999). If possible, biovolume calculations were based on measurements of 10 organisms per taxon for each sample.

Zooplankton samples were collected at each sampling station during most sampling trips (tables 1 and 2). Three vertical tows with a standard zooplankton net $(20-\mathrm{cm}[0.7-\mathrm{ft}]$ mouth, $80-\mathrm{cm}$ [2.6-ft] length, and 64- $\mu \mathrm{m}$ [0.003 in.] mesh) were collected as one sample and preserved using at least a 2 percent Lugol's solution. For later identification and enumeration, 3-4 percent Lugol's solution was added depending on the amount of detritus in the sample, as requested by Dr. John Beaver (John Beaver, written commun., 2011). Vertical tows were up to $2 \mathrm{~m}$ (6.6 ft) in length, depending on the depth at each sample station.
Zooplankton were identified, and density and biomass estimates made, by BSA Environmental Services, Inc.; biomass calculations were based on established length/width relationships of zooplankton anatomy (Dumont and others, 1975; Lawrence and others, 1987). Biomass was computed for the appropriate number of individuals for each sample location and the arithmetic mean biomass was multiplied by the number of species to produce a species biomass for each sample (McCauley, 1984). Zooplankton data for each taxonomic group were reported as biomass (micrograms dry weight/liter [pounds per gallon]) and density (number of individuals/liter [number of individuals/gallon]).

\section{Small Biota Sampling}

Small biota included the aquatic macroinvertebrates and crayfish that were sampled from shore near each sampling station as shown in tables 1 and 2. Aquatic macroinvertebrates

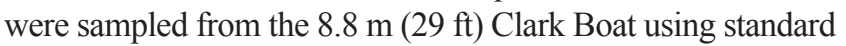
methods (Nelson and others, 2000). For consistency, we sought shoreline locations with a patch of spiny naiad, which is the most abundant SAV species and, therefore, good habitat for aquatic macroinvertebrates. A D-frame sweep net (700- $\mu \mathrm{m}$ [0.028-in.] mesh) was swept along the length of the boat perpendicular to the shoreline; the bottom of the net lightly scraped but did not dig into the bottom substrate. Although attempting to sample the same volume of habitat at each sample location, the goal was not to detect all macroinvertebrate taxa within Topock Marsh but to obtain comparable representative samples of common aquatic macroinvertebrates living within the spiny naiad and along the bottom surface. Three net sweeps were conducted at each location on each sampling date. Sample locations were recorded using a GPS. Mean water depth at each location was estimated from three depths taken equidistant along the sweep with a meter stick. The macroinvertebrates were either sorted in the field or the samples were preserved with ethanol for sorting in the laboratory. Macroinvertebrates were primarily identified to genus, although some Odonata and Oligochaeta were identified to family and some Diptera were identified to subfamily. Identification was done under contract by Richard Durfee, a macroinvertebrate biologist of Hamilton, Montana. Data were reported as the sum of organisms collected at each sample location and date.

\section{Fish Sampling}

\section{Annual Gill Net Surveys Conducted by the Arizona Game and Fish Department}

The Arizona Game and Fish Department's (AGFD's) Kingman office conducted gill net surveys at Topock Marsh each February from 2010 to 2015 at 10 locations within the marsh. AGFD biologists used experimental gill nets that are 45.7-m (150-ft) long, and consist of six 7.6-m (25 ft) panels with different mesh sizes ranging from 12 to 76 millimeters ( 0.5 to $3.0 \mathrm{in}$.) to capture different species and size classes of fish. AGFD set the nets so that the mesh size closest to shore 
varied. GPS locations were recorded at each net location. For $2-3$ consecutive days, nets were typically deployed in the late afternoon and retrieved the following morning, and because all deployment and retrieval times were recorded, the total number of hours that each net was deployed was calculated. All captured fish were identified, measured, and weighed before release and, after 2010, razorback suckers were scanned for pit-tags. AGFD provided the fish survey reports for 2010, 2011, 2012, 2013, 2014, and 2015 (app. 2). The survey protocol and personnel were the same each year, therefore, results from these February fish surveys were used to evaluate changes in fish populations between sampling years. In the reports, AGFD used the estimate of catch per unit effort as a surrogate measure of fish abundance. For gill nets, catch per unit effort was calculated as the number of fish captured per hour per net.

\section{Results}

\section{Water-Quality Characteristics}

\section{Physicochemistry}

Water temperatures were measured instantaneously within a vertical profile using a Hydrolab Quanta ${ }^{\circledR}$ (fig. 4) and measured hourly at a fixed location with Hydrolab MiniSondes ${ }^{\circledR}$ (fig. 5) that were deployed for periods lasting from 2.5 to 9 days. Water temperatures were obtained at each of the 4 sampling stations on 11 sampling dates and at 2 stations in December 2013. Maximum water temperatures reached $33.2^{\circ} \mathrm{C}\left(91.8^{\circ} \mathrm{F}\right)$ just under the water surface at TP-2 during July 2011 , and $35.8^{\circ} \mathrm{C}\left(96.4^{\circ} \mathrm{F}\right)$ at TP-3 during July 2013 (figs. 4 and 5). The lowest water temperatures measured were $9.5^{\circ} \mathrm{C}\left(49.1^{\circ} \mathrm{F}\right)$ at TP-2 and TP-3 in February 2012 and $5.2^{\circ} \mathrm{C}\left(41.4^{\circ} \mathrm{F}\right)$ at TP-3 in December 2013 (figs. 4 and 5). Measurements at TP-3, the shallowest sampling station (1.2 $\mathrm{m}[3.9 \mathrm{ft}]$ deep or less), contained the widest temperature extremes at a single location (fig. $4 B a$ ). TP-2, the deepest sampling station $(2.9 \mathrm{~m}[9.5 \mathrm{ft}]$ deep at its deepest during June 2013 and April 2014), displayed the greatest temperature change with depth; that is, $30.2^{\circ} \mathrm{C}$ $\left(86.4^{\circ} \mathrm{F}\right)$ just under the water surface to $24.5^{\circ} \mathrm{C}\left(76.1^{\circ} \mathrm{F}\right)$ at the depth of $2.3 \mathrm{~m}(7.5 \mathrm{ft}$ ) on September 21, 2011, (fig. 4Ab) and $29.5^{\circ} \mathrm{C}\left(85.1^{\circ} \mathrm{F}\right)$ just under the water surface to $21.3^{\circ} \mathrm{C}$ $\left(70.3^{\circ} \mathrm{F}\right)$ at the depth of $2.9 \mathrm{~m}(9.5 \mathrm{ft})$ on June 12, 2013, (fig. $4 B b$ ). In contrast, during June 2013, Colorado River water temperatures just downstream of the Needles Bridge and approximately $4 \mathrm{~km}(2.5 \mathrm{mi})$ upstream of the Fire Break Canal Water Diversion Structure, averaged $20.9^{\circ} \mathrm{C}\left(69.6^{\circ} \mathrm{F}\right)$ (Scott O'Meara, Bureau of Reclamation, unpub. data, 2014). During the cooler months, there was not as large a temperature difference between the marsh and the river (fig. 2A). However, temperatures at other locations in the marsh remained fairly constant from surface to bottom (that is, the entire water column) through the seasons, with the exception of TP- 8 in July 2013 where there were notable temperature differences between the surface and at $0.5 \mathrm{~m}(1.6 \mathrm{ft}$ ) depth (fig. $4 B d$ ).

Following the 260-day period of no flow through the Inlet Canal in 2011, SC values during the first sampling trip in July 2011 were higher at TP-3 and TP-2 with $2,470 \mu \mathrm{S} / \mathrm{cm}$ (1,583 parts per million [ppm]) and 2,600 $\mu \mathrm{S} / \mathrm{cm}(1,667 \mathrm{ppm})$, respectively, than at TP-6 with $1,970 \mu \mathrm{S} / \mathrm{cm}(1,263 \mathrm{ppm})$, and the $\mathrm{SC}$ at TP- 8 was even lower at $1,158 \mu \mathrm{S} / \mathrm{cm}(742 \mathrm{ppm})$ (figs. $6 A$ and $7 A$ and table 4). During this time, inflow was still coming from the Farm Ditch Canal (see fig. $2 A$ ). In September 2011, following a two-month period of fairly constant but relatively low flows from the Inlet Canal (fig. $2 A$ ), $\mathrm{SC}$ dropped to $995 \mu \mathrm{S} / \mathrm{cm}(638 \mathrm{ppm})$ at TP-3 and rose to $1,550 \mu \mathrm{S} / \mathrm{cm}(994 \mathrm{ppm}$ ) at TP-8 (table 4). Interestingly, SC at TP-2 was $1,412 \mu \mathrm{S} / \mathrm{cm}(905 \mathrm{ppm})$ just under the water surface but decreased to $1,132 \mu \mathrm{S} / \mathrm{cm}(726 \mathrm{ppm})$ at the $2.3 \mathrm{~m}(7.5 \mathrm{ft})$ water depth. During that time, operational testing of the Fire Break Canal temporarily brought Colorado River water directly into the marsh at TP-2 (fig. 6Ab), thus lowering SC and water temperature with depth. By October 2011, after an average daily flow from the Inlet Canal of 0.286 cubic meters per second $\left(\mathrm{m}^{3} / \mathrm{s}\right)$, which is equivalent to 10.1 cubic feet per second $\left(\mathrm{ft}^{3} / \mathrm{s}\right)$, and a flow rate of $0.139 \mathrm{~m}^{3} / \mathrm{s}\left(4.9 \mathrm{ft}^{3} / \mathrm{s}\right)$ from the Farm Ditch Canal (fig. 2A), SC increased at TP-6 and TP-8 (figs. $6 A c, 6 A d$, and $7 A$ ), and the trend of higher SCs moving downstream continued into March 2012, as SC at TP-8 increased to 2,390 $\mu \mathrm{S} / \mathrm{cm}(1,532 \mathrm{ppm})$ (fig. $6 \mathrm{Ad}$ and table 4).

Compared to the July 2011-March 2012 low water sampling period, SC did not vary as much seasonally during 2013-14. Instead, the most downstream sampling station, TP-8, consistently experienced the highest $\mathrm{SC}$ values, ranging from $1,757 \mu \mathrm{S} / \mathrm{cm}(1,126 \mathrm{ppm})$ to $2,115 \mu \mathrm{S} / \mathrm{cm}(1,356 \mathrm{ppm})$ (figs. $6 B d$ and $7 B$ ). TP-2, adjacent to where inflow from the Colorado River enters the marsh, typically experienced the lowest $\mathrm{SC}$ values, ranging from 900 to $1,599 \mu \mathrm{S} / \mathrm{cm}$ (577 to $1,025 \mathrm{ppm}$ ), particularly during the growing season when inflows were high and the cool, fresher river water, with an average temperature of $20.5^{\circ} \mathrm{C}$ $\left(68.9^{\circ} \mathrm{F}\right)$ and an SC of $895.5 \mu \mathrm{S} / \mathrm{cm}(574 \mathrm{ppm})$ (Scott O'Meara, written commun., 2014), plunged to the deeper spots thus lowering the $\mathrm{SC}$ at those depths (fig. $6 \mathrm{Bb}$ ). The exception was during December 2013 when there was virtually no flow into the marsh from any of the inlets for 29 days (fig. $2 A$ ). Interestingly, at that time, TP-3, the most upstream station, had lower SC values than TP-2. In February 2014, the marsh was at its lowest elevation of the year (fig. $2 B$ ) because of very little inflow and SC increased throughout the marsh. However, by the April 2014 sampling trip, $\mathrm{SC}$ values decreased again following higher inflows that began in mid-March. TP-3 had the second lowest SC values during the April 2014 sampling trip. At the beginning of the September 2014 sampling trip, TP-3 had higher SC values than TP-6. However, as time went on, SC decreased at TP-3 and increased at TP- 6 so that by October 2, 2014, at 1600 hours, TP-6 was slightly higher than TP-3 and remained higher for the rest of the sampling trip. (fig. $7 B$ ). 

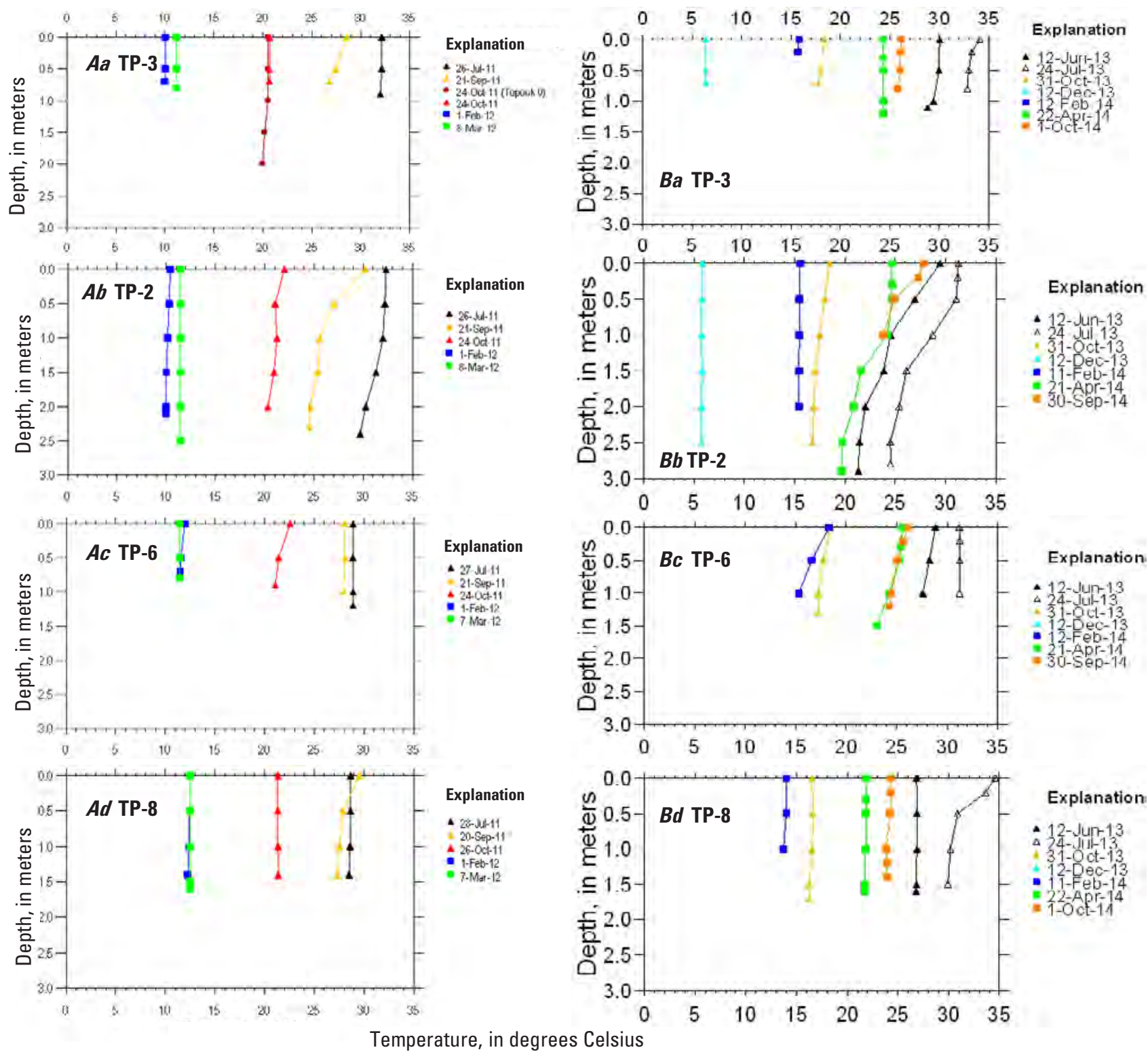

Figure 4. Depth profiles of water temperatures in Topock Marsh during 2011 and 2012 ( $A$, charts on left) and 2013 and 2014 ( $B$, charts on right) at sampling stations TP-3, TP-2, TP-6, and TP-8. Stations are displayed in upstream to downstream order, top to bottom, but numbering is not sequential. Colors represent seasons (blue = winter, green $=$ spring, black = summer, yellow and red $=$ fall) and symbols represent year ( $\bullet$ or $\boldsymbol{\Delta}=2011$ and 2013, $\mathbf{a}=2012$ and 2014). 

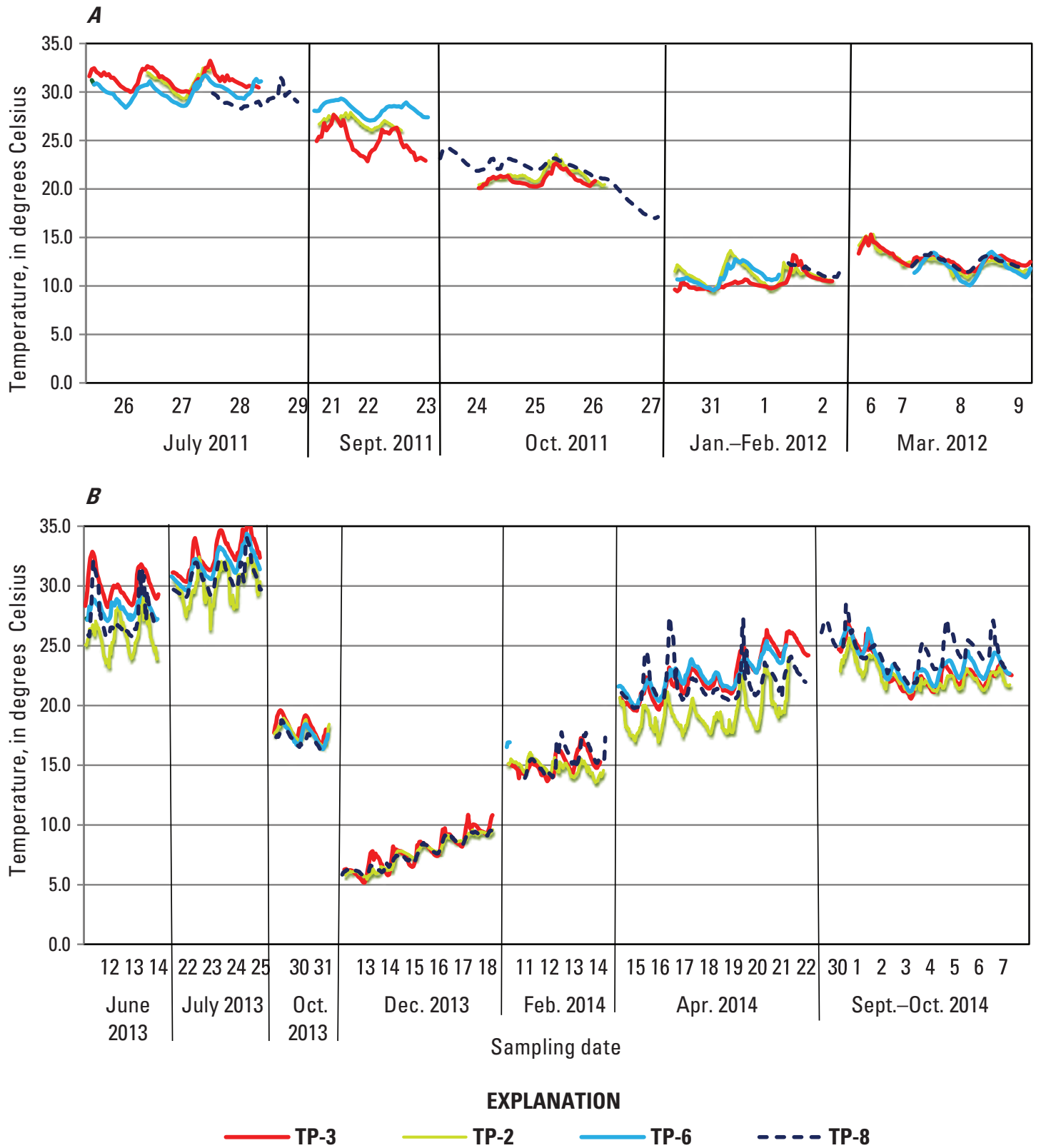

Figure 5. Diurnal temperatures in Topock Marsh at sampling stations TP-3, TP-2, TP-6, and TP-8 during site visits from July 2011 to March 2012 (A) and from June 2013 to September/October 2014 (B). Stations are displayed in upstream to downstream order, but numbering is not sequential. 

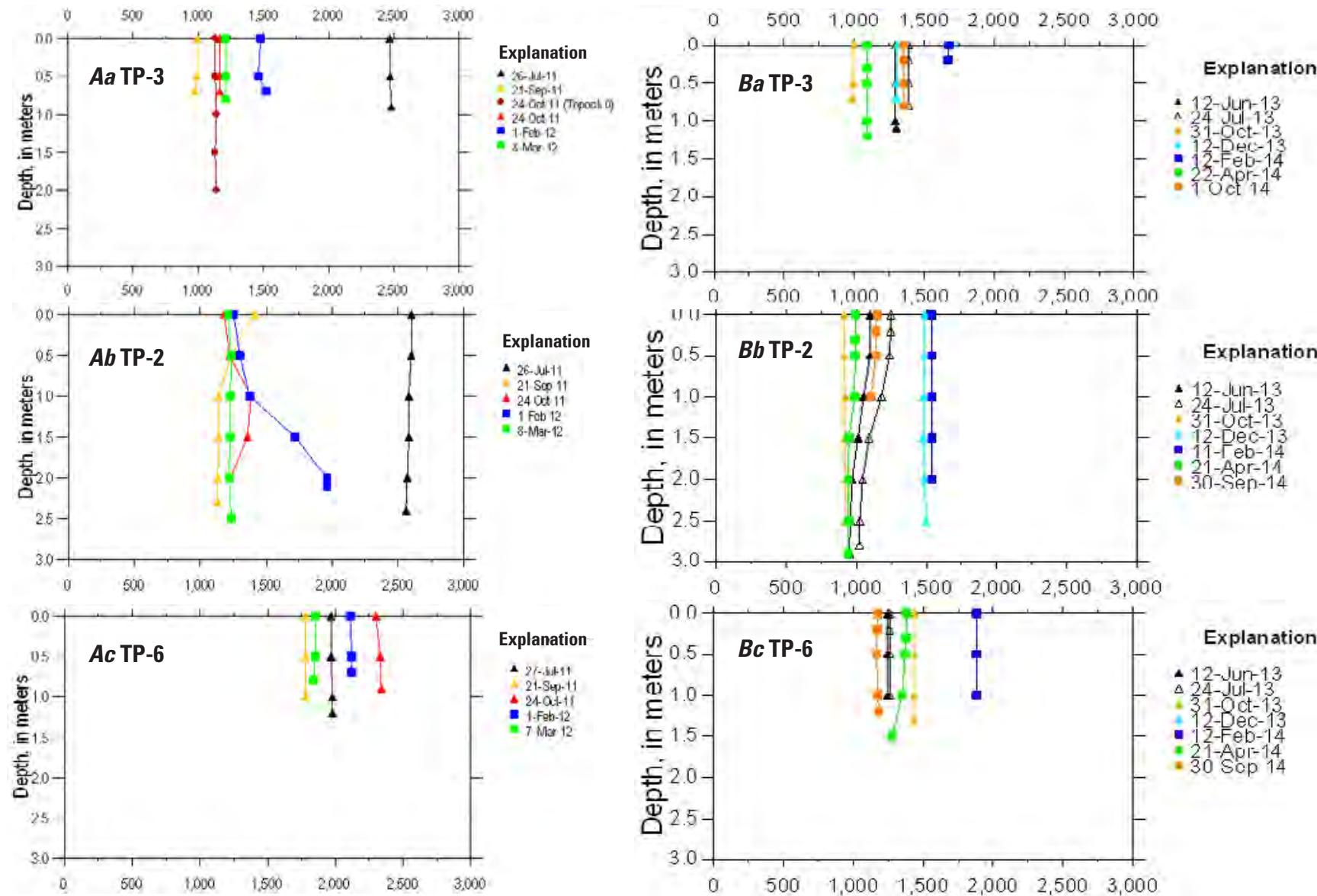

Explanation

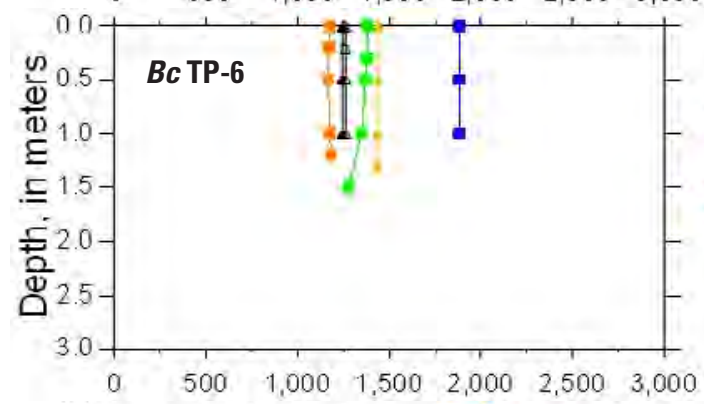

Explanation

- 2(-3it)

$21-5$ tp -11

24 at-

- 7 . Fob - 12
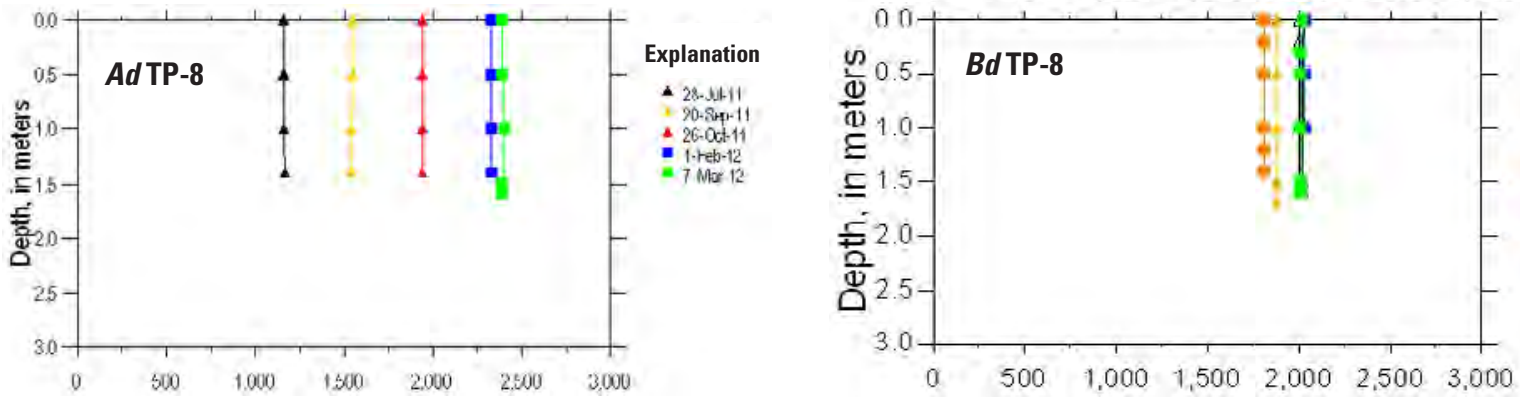

Explanation

Explanation

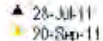

$\pm 26-00 t-11$

- 1. teb- 12

Specific conductance, in microsiemens per centimeter

Figure 6. Depth profiles of specific conductance in Topock Marsh during 2011 and 2012 ( $A$, charts on left) and 2013 and 2014 ( $B$, charts on right) at sampling stations TP-3, TP-2, TP-6, and TP-8. Stations are displayed in upstream to downstream order, top to bottom, but numbering is not sequential. Colors represent seasons (blue = winter, green = spring, black = summer, fall = yellow or red) and symbols represent year ( $\bullet$ or $\boldsymbol{\Delta}=2011$ and 2013, $\mathbf{\square}=2012$ and 2014). 

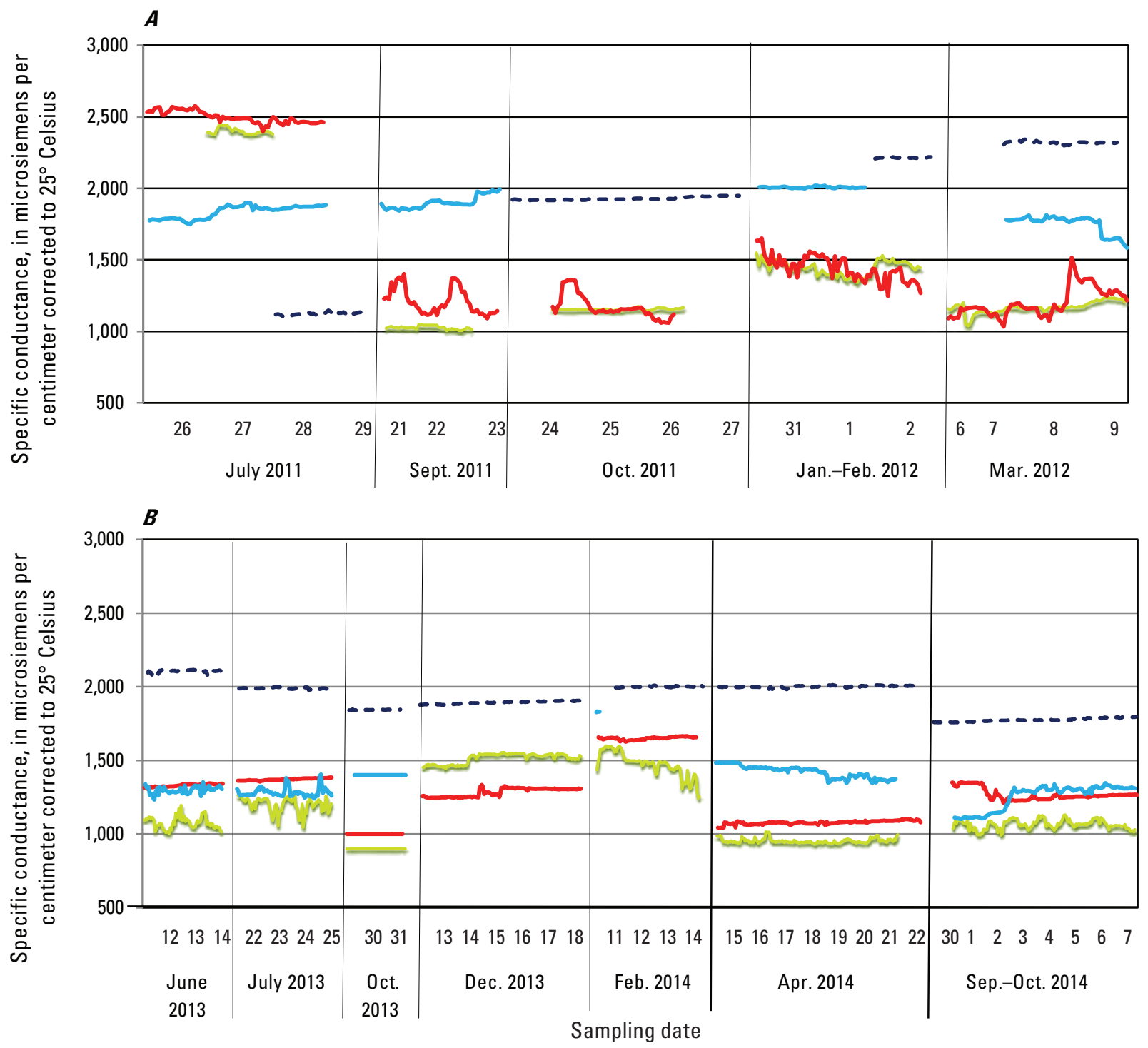

EXPLANATION

TP-3

TP-2

TP-6 2- - TP-8

Figure 7. Diurnal specific conductance in Topock Marsh at sampling stations TP-3, TP-2, TP-6, and TP-8 during site visits from July 2011 to March 2012 (A) and June 2013 to September/October $2014(B)$. Stations are displayed in upstream to downstream order, but numbering is not sequential. 
Table 4. Concentrations of water-quality constituents collected from Topock Marsh in July, September, and October 2011; February and March 2012; June, July, and October 2013; and February, April, and September/October 2014.

$\left[\mu \mathrm{S} / \mathrm{cm}\right.$, microsiemens per centimeter; NTU, nephelometric turbidity unit; TSS, total suspended solids; mg/L, milligram per liter; $\mathrm{CaCO}_{3}$, calcium carbonate; $\mathrm{P}$, phosphorus; $\mathrm{NH}$, , ammonia; Org-N, organic nitrogen; $\mathrm{NH}_{3}-\mathrm{N}$, ammonia-nitrogen; $\mathrm{NO}_{3}+\mathrm{NO}_{2}-\mathrm{N}$, nitrate + nitrite nitrogen; $\mathrm{N}$, nitrogen; TN, total nitrogen; \%, percentage; TP, sampling station; $\mathrm{ND}$, no data; $\mathrm{NWQL}$, National Water Quality Laboratory; Calc., calculated; EPA, U.S. Environmental Protection Agency; ADEQ, Arizona Department of Environmental Quality]

\begin{tabular}{|c|c|c|c|c|c|c|c|c|c|c|c|c|}
\hline \multirow[b]{2}{*}{$\begin{array}{l}\text { Sample } \\
\text { station }^{2}\end{array}$} & \multirow[b]{2}{*}{$\begin{array}{c}\text { Sample } \\
\text { date }\end{array}$} & \multicolumn{2}{|c|}{ Surface values from Quanta } & \multicolumn{9}{|c|}{ Laboratory analyses from surface samples ${ }^{1}$} \\
\hline & & $\begin{array}{c}\text { Specific } \\
\text { conductance } \\
\mu \mathrm{S} / \mathrm{cm}\end{array}$ & $\begin{array}{c}\text { Turbidity } \\
\text { NTUs }\end{array}$ & $\begin{array}{l}\text { TSS } \\
\mathrm{mg} / \mathrm{L}\end{array}$ & $\begin{array}{c}\text { Alkalinity as } \\
\mathrm{CaCO}_{3} \\
\mathrm{mg} / \mathrm{L}\end{array}$ & $\begin{array}{c}\text { Total P } \\
\mathrm{mg} / \mathrm{L}\end{array}$ & $\begin{array}{c}\mathrm{NH} 3+\text { Org-N } \\
\text { mg/L }\end{array}$ & $\begin{array}{c}\mathrm{NH}_{3}-\mathrm{N} \\
\mathrm{mg} / \mathrm{L}\end{array}$ & $\begin{array}{c}\text { Org-N } \\
\mathrm{mg} / \mathrm{L}\end{array}$ & $\begin{array}{c}\mathrm{NO3+N02-N} \\
\mathrm{mg} / \mathrm{L}\end{array}$ & $\begin{array}{c}\text { Total-N } \\
\mathrm{mg} / \mathrm{L}\end{array}$ & $\begin{array}{c}\text { Org-N/ } \\
\text { TN } \\
\%\end{array}$ \\
\hline TP-3 & $07 / 26 / 11$ & 2,470 & 4.0 & & 156.0 & 0.029 & 0.920 & $<0.007$ & 0.916 & $<0.007$ & 0.923 & 99.2 \\
\hline TP-2 & $07 / 26 / 11$ & 2,600 & 68.9 & & 161.6 & 0.036 & 0.992 & 0.019 & 0.973 & $<0.007$ & 0.995 & 97.7 \\
\hline TP-6 & $07 / 27 / 11$ & 1,970 & 39.3 & & 147.2 & 0.026 & 0.629 & $<0.007$ & 0.626 & 0.020 & 0.649 & 96.4 \\
\hline TP-8 & $07 / 28 / 11$ & 1,158 & 53.0 & & 144.8 & 0.038 & 0.654 & $<0.007$ & 0.651 & 0.010 & 0.664 & 98.0 \\
\hline TP-3 & $09 / 21 / 11$ & 995 & 58.4 & & 99.2 & 0.053 & 0.323 & $<0.004$ & 0.321 & 0.015 & 0.338 & 95.0 \\
\hline TP-2 & $09 / 21 / 11$ & 1,412 & 51.4 & & 114.4 & 0.053 & 0.540 & $<0.004$ & 0.538 & $<0.007$ & 0.543 & 99.0 \\
\hline TP-6 & $09 / 21 / 11$ & 1,780 & 19.9 & & 54.4 & 0.049 & 0.611 & $<0.004$ & 0.609 & $<0.007$ & 0.614 & 99.1 \\
\hline TP-8 & 09/20/11 & 1,550 & 30.5 & & 93.6 & 0.055 & 0.935 & $<0.004$ & 0.933 & $<0.007$ & 0.938 & 99.4 \\
\hline TP-3 & $10 / 25 / 11$ & 1,165 & 60.3 & & 112.8 & 0.026 & & ND & & ND & 0.388 & \\
\hline TP-2 & $10 / 25 / 11$ & 1,183 & 45.0 & & 86.4 & 0.025 & & ND & & ND & 0.483 & \\
\hline TP-6 & $10 / 25 / 11$ & 2,300 & 37.4 & & 48.8 & 0.025 & & ND & & ND & 0.719 & \\
\hline TP-8 & $10 / 23 / 11$ & 1,940 & 35.8 & & 72.0 & 0.075 & & ND & & ND & 1.050 & \\
\hline 2011 mean & & 1710 & 42.0 & & 107.6 & 0.041 & 0.700 & 0.019 & 0.696 & 0.015 & 0.692 & 98.0 \\
\hline TP-3 & $02 / 01 / 12$ & 1,478 & 72.6 & & 148.0 & 0.040 & 0.421 & 0.030 & 0.392 & 0.193 & 0.614 & 63.8 \\
\hline TP-2 & $02 / 01 / 12$ & 1,253 & 13.2 & & 144.0 & 0.014 & 0.268 & $<0.010$ & 0.263 & 0.345 & 0.613 & 42.9 \\
\hline TP-6 & $02 / 01 / 12$ & 2,110 & 49.8 & & 163.0 & 0.043 & 0.716 & 0.040 & 0.676 & 0.054 & 0.770 & 87.8 \\
\hline TP-8 & $02 / 01 / 12$ & 2,330 & 81.1 & & 158.0 & 0.087 & 1.320 & 0.024 & 1.296 & 0.010 & 1.330 & 97.4 \\
\hline TP-3 & 03/08/12 & 1,209 & 87.4 & & 140.0 & 0.039 & 0.360 & 0.034 & 0.326 & 0.256 & 0.616 & 53.0 \\
\hline TP-2 & $03 / 08 / 12$ & 1,210 & 51.8 & & 142.0 & 0.037 & 0.371 & 0.025 & 0.346 & 0.284 & 0.655 & 52.9 \\
\hline TP-6 & $03 / 08 / 12$ & 1,850 & 63.1 & & 150.0 & 0.051 & 0.645 & 0.034 & 0.611 & 0.124 & 0.769 & 79.5 \\
\hline TP-8 & 03/09/12 & 2,390 & 70.3 & & 164.0 & 0.081 & 1.080 & 0.011 & 1.070 & 0.110 & 1.190 & 89.9 \\
\hline 2012 mean & & 1729 & 61.2 & & 151.1 & 0.049 & 0.648 & 0.028 & 0.622 & 0.172 & 0.820 & 70.9 \\
\hline $\begin{array}{c}\text { 2011-2012 } \\
\text { study average }\end{array}$ & & 1718 & 49.7 & & 125.0 & 0.044 & 0.674 & 0.027 & 0.659 & 0.129 & 0.743 & 84.4 \\
\hline TP-3 & $06 / 13 / 13$ & 1,311 & 58.8 & 16 & 179 & 0.034 & 0.49 & 0.01 & 0.47 & 0.00 & 0.464 & 96.8 \\
\hline TP-2 & $06 / 13 / 13$ & 1,140 & 66.8 & $<15$ & 164 & 0.023 & 0.41 & $<0.01$ & 0.40 & 0.00 & 0.408 & 98.0 \\
\hline TP-6 & $06 / 13 / 13$ & 1,291 & 19.5 & $<15$ & 173 & 0.026 & 0.52 & $<0.01$ & 0.52 & 0.00 & 0.483 & 99.0 \\
\hline TP-8 & $06 / 13 / 13$ & 2,030 & 88.2 & 40 & 181 & 0.085 & 1.18 & 0.02 & 1.16 & 0.00 & 1.170 & 99.4 \\
\hline TP-3 & $07 / 24 / 13$ & 1,389 & 18 & ND & ND & 0.027 & 0.51 & 0.01 & 0.49 & 0.00 & 0.495 & 99.8 \\
\hline TP-2 & $07 / 24 / 13$ & 1,244 & 11.8 & ND & ND & 0.031 & 0.49 & 0.01 & 0.48 & 0.01 & 0.500 & 96.5 \\
\hline TP-6 & $07 / 24 / 13$ & 1,259 & 17.7 & ND & ND & 0.027 & 0.59 & $<0.01$ & 0.59 & 0.00 & 0.562 & 99.1 \\
\hline TP-8 & $07 / 23 / 13$ & 2,000 & 26.5 & ND & ND & 0.066 & 1.31 & $<0.01$ & 1.31 & 0.10 & 1.407 & 92.8 \\
\hline TP-3 & $10 / 31 / 13$ & 1,000 & 11.3 & $<15$ & 86.6 & 0.015 & 0.26 & $<0.01$ & 0.26 & 0.02 & 0.275 & 92.7 \\
\hline TP-2 & $10 / 31 / 13$ & 911 & 7.8 & $<15$ & 130.0 & 0.008 & 0.205 & $<0.01$ & 0.20 & 0.22 & 0.427 & 46.8 \\
\hline
\end{tabular}


Table 4. Concentrations of water-quality constituents collected from Topock Marsh in July, September, and October 2011; February and March 2012; June, July, and October 2013; and February, April, and September/October 2014.-Continued

$\left[\mu \mathrm{S} / \mathrm{cm}\right.$, microsiemens per centimeter; NTU, nephelometric turbidity unit; TSS, total suspended solids; mg/L, milligram per liter; $\mathrm{CaCO}_{3}$, calcium carbonate; $\mathrm{P}$, phosphorus; $\mathrm{NH}{ }_{3}$, ammonia; Org- $\mathrm{N}$, organic nitrogen; $\mathrm{NH}_{3}-\mathrm{N}$, ammonia-nitrogen; $\mathrm{NO}_{3}+\mathrm{NO}_{2}-\mathrm{N}$, nitrate + nitrite nitrogen; $\mathrm{N}$, nitrogen; TN, total nitrogen; \%, percentage; TP, sampling station; ND, no data; NWQL, National Water Quality Laboratory; Calc., calculated; EPA, U.S. Environmental Protection Agency; ADEQ, Arizona Department of Environmental Quality]

\begin{tabular}{|c|c|c|c|c|c|c|c|c|c|c|c|c|}
\hline \multirow[b]{2}{*}{$\begin{array}{l}\text { Sample } \\
\text { station }^{2}\end{array}$} & \multirow[b]{2}{*}{$\begin{array}{l}\text { Sample } \\
\text { date }\end{array}$} & \multicolumn{2}{|c|}{ Surface values from Quanta } & \multicolumn{9}{|c|}{ Laboratory analyses from surface samples ${ }^{1}$} \\
\hline & & $\begin{array}{c}\text { Specific } \\
\text { conductance } \\
\mu S / \mathrm{cm}\end{array}$ & $\begin{array}{c}\text { Turbidity } \\
\text { NTUs }\end{array}$ & $\begin{array}{l}\text { TSS } \\
\mathrm{mg} / \mathrm{L}\end{array}$ & $\begin{array}{l}\text { Alkalinity as } \\
\mathrm{CaCO}_{3} \\
\mathrm{mg} / \mathrm{L}\end{array}$ & $\begin{array}{l}\text { Total P } \\
\mathrm{mg} / \mathrm{L}\end{array}$ & $\begin{array}{c}\mathrm{NH} 3+\text { Org-N } \\
\mathrm{mg} / \mathrm{L}\end{array}$ & $\begin{array}{l}\mathrm{NH}_{3}-\mathrm{N} \\
\mathrm{mg} / \mathrm{L}\end{array}$ & $\begin{array}{l}\text { Org-N } \\
\mathrm{mg} / \mathrm{L}\end{array}$ & $\begin{array}{c}\text { NO3+NO2-N } \\
\mathrm{mg} / \mathrm{L}\end{array}$ & $\begin{array}{c}\text { Total-N } \\
\text { mg/L }\end{array}$ & $\begin{array}{l}\text { Org-N/ } \\
\text { TN } \\
\%\end{array}$ \\
\hline TP-6a & $10 / 31 / 13$ & 1,440 & 11.2 & $<15$ & 110.0 & 0.017 & 0.499 & $<0.01$ & 0.49 & 0.01 & 0.508 & 97.2 \\
\hline TP-6b & $10 / 31 / 13$ & ND & ND & 15 & 110.0 & 0.018 & 0.515 & $<0.01$ & 0.51 & 0.00 & 0.480 & 99.0 \\
\hline TP-8 & $10 / 31 / 13$ & 1,880 & 134 & 80 & 163.0 & 0.188 & 1.21 & $<0.01$ & 1.21 & 0.20 & 1.410 & 85.5 \\
\hline 2013 mean & & 1,408 & 39.3 & 38 & 144.1 & 0.043 & 0.630 & 0.013 & 0.62 & 0.04 & 0.661 & 92.5 \\
\hline ТP-3 & $02 / 12 / 2014$ & 1,675 & 50.3 & 24 & 178.0 & 0.053 & 0.695 & 0.060 & 0.635 & 0.031 & 0.726 & 87.5 \\
\hline TP-2 & $02 / 11 / 2014$ & 1,540 & 56.8 & 29 & 146.0 & 0.063 & 0.787 & 0.025 & 0.762 & 0.067 & 0.854 & 89.2 \\
\hline TP-6 & $02 / 12 / 2014$ & 1,880 & 38.7 & 14 & 191.0 & 0.047 & 0.858 & 0.039 & 0.819 & $<0.010$ & 0.863 & 94.9 \\
\hline TP-8 & $02 / 11 / 2014$ & 2,030 & 112.0 & 97 & 193.0 & 0.154 & 1.835 & 0.281 & 1.554 & 0.025 & 1.860 & 83.5 \\
\hline TP-3 & 04/19/2014 & 1,092 & 72.6 & 46 & 156.0 & 0.056 & 0.472 & 0.011 & 0.461 & $<0.010$ & 0.477 & 96.7 \\
\hline TP-2 & 04/19/2014 & 993 & 34.6 & $<15$ & 148.0 & 0.026 & 0.353 & $<0.010$ & 0.348 & 0.168 & 0.521 & 66.8 \\
\hline TP-6 & 04/19/2014 & 1,379 & 33.6 & 16 & 169.0 & 0.033 & 0.599 & 0.017 & 0.582 & 0.011 & 0.598 & 97.3 \\
\hline TP-8 & $04 / 19 / 2014$ & 2,020 & 140.0 & 84 & 192.0 & 0.171 & 1.502 & 0.058 & 1.444 & 0.021 & 1.470 & 98.2 \\
\hline TP-3 & $10 / 1 / 2014$ & 1,353 & 73.7 & 34 & 150.0 & 0.057 & 0.609 & 0.017 & 0.592 & 0.015 & 0.624 & 94.9 \\
\hline ТР-2 & 09/30/2014 & 1,149 & 41.5 & $<15$ & 145.0 & 0.031 & 0.387 & 0.023 & 0.364 & 0.073 & 0.460 & 79.1 \\
\hline ТР-6a & $09 / 30 / 2014$ & 1,174 & 11.4 & $<15$ & 72.6 & 0.018 & 0.440 & 0.017 & 0.423 & $<0.010$ & 0.445 & 95.1 \\
\hline TP-6b & 09/30/2014 & ND & ND & $<15$ & 78.2 & 0.023 & 0.453 & 0.015 & 0.438 & $<0.010$ & 0.458 & 95.7 \\
\hline TP-8 & $10 / 1 / 2014$ & 1,810 & 83.7 & 40 & 118.0 & 0.133 & 1.399 & 0.021 & 1.378 & 0.011 & 1.410 & 97.8 \\
\hline \multicolumn{2}{|c|}{2014 mean minus TP-8 } & & 45.9 & & & & & & & & & \\
\hline \multicolumn{2}{|l|}{2014 mean } & 1,508 & 62.4 & 43 & 149.0 & 0.067 & 0.799 & 0.049 & 0.754 & 0.047 & 0.828 & 90.5 \\
\hline \multicolumn{2}{|c|}{$\begin{array}{c}\text { 2013-2014 } \\
\text { study average }\end{array}$} & 1,458 & 50.9 & 41.2 & 147.0 & 0.055 & 0.715 & 0.040 & 0.688 & 0.045 & 0.744 & 91.5 \\
\hline \multicolumn{4}{|c|}{ NWQL Laboratory Codes } & 169 & 2109 & 2333 & 1986, Calc. $^{3}$ & & 3116 Calculated ${ }^{3,4}$ & Calc. ${ }^{4}, 3157$ & 2756 & Calculated \\
\hline \multirow{3}{*}{\multicolumn{4}{|c|}{$\begin{array}{l}\text { NWQL Analytical Method Identification Codes } \\
\text { NWQL minimum reporting level } \\
\text { ADEQ numeric targets for nutrients }{ }^{5}\end{array}$}} & I-3765-89 & I-2030-89 & EPA 365.1 & \multicolumn{3}{|c|}{ I-2525-89,I-2522-90 } & \multicolumn{3}{|c|}{$\mathrm{I}-4650-03$} \\
\hline & & & & 15 & 4.6 & 0.004 & \multirow{2}{*}{\multicolumn{3}{|c|}{0.01}} & \multicolumn{3}{|c|}{0.05} \\
\hline & & & & & & $0.115-0.140$ & & & & & $1.6-1.8$ & \\
\hline
\end{tabular}

${ }^{1}$ All 2011 laboratory analyses were done by Reclamation's LC Regional Laboratory and all 2012, 2013, and 2014 laboratory analyses were done by the USGS NWQL. All samples, including the Quanta values, were taken at the sampling stations from just below the water's surface.

${ }^{2}$ Sampling stations are displayed in upstream to downstream order.

${ }^{3} 2014$ values for NH3-N + Org-N and Org-N are calculated using half of "less than" detection limits for analyzed parameters. Formulas to calculate nitrogen forms follow those provided by Bales and others, 2001. ${ }^{4} 2013$ values for Org-N and NO3+NO2-N were calculated using half of "less than" detection limits for analyzed parameters. Formulas to calculate nitrogen forms follow those provided by Bales and others, 2001. ${ }^{5}$ The standards recommended by the Arizona Department of Environmental Quality (ADEQ) are specific to warmwater lakes and reservoirs designated for aquatic and wildlife use. Ranges apply to peak season (April to October for warm water lakes).All criteria were obtained from ADEQ (2009).

Values in red are less than $80 \%$ organic nitrogen to total nitrogen. 
Values for $\mathrm{pH}$ showed some seasonal change. In July 2011, $\mathrm{pH}$ was very similar between the sampling stations, hovering near 8.0 regardless of the time of day (figs. $8 A$ and $9 A$ ). By September 2011, there was more variation between the upstream and the downstream sampling stations; $\mathrm{pH}$ values ranged between 8.1 and 8.4 at TP-3 and TP-2, and between 8.4 and 9.0 at TP-6 and TP-8. October 2011 values varied the most, with a low of 7.8 at TP-2 and a high of 9.1 at TP-6. In January/February 2012, $\mathrm{pH}$ values were fairly consistent among sampling stations and water depth, and in March 2012, pH was slightly higher at TP-6 and TP-8.

Comparing $\mathrm{pH}$ values during 2013-14, the mean values increased slightly from June and July 2013 to October 2013, varying from a low of 7.9 at TP-8 in June to 9.1 at TP-3 in October (figs. $8 B$ and $9 B$ ). The larger daily $\mathrm{pH}$ fluctuations at TP-3 during October and December 2013; at TP-6 each October (2013 and 2014); and at TP-8 in June, July, and October 2013 and April and October 2014, were especially pronounced (fig. 9B). The opposite was true throughout the marsh in February 2014, when $\mathrm{pH}$ values had much smaller daily fluctuations. Otherwise, $\mathrm{pH}$ ranged from 7.6 to 9.1 throughout the study period.

Dissolved oxygen concentrations varied seasonally and tended to be inversely related to temperature (compare figure 4 to figure 10 and figure 5 to figure 11). These concentrations were measured in $\mathrm{mg} / \mathrm{L}$, which is equivalent to $\mathrm{ppm}$. The DO concentration was well above the minimum threshold of $3.0 \mathrm{mg} / \mathrm{L}$ that is established as the one-day criteria for "other life stages" of warm water fish by the U.S. Environmental Protection Agency (1986a).

Figure 12 illustrates water surface turbidity measured at each sampling station during the sampling period, figure 13 illustrates the turbidity depth profiles at each sampling station, and the turbidity diurnal trends from 2013 and 2014 are illustrated on figure 14.

Turbidity readings at the 4 sampling stations averaged 47.2 NTUs in 2011 and 61.2 NTUs in 2012 (table 4). TP-6 generally had higher water clarity than the other sites in 2011, as indicated by its average lower turbidity values (32.2 NTUs, number $[\mathrm{n}]=3)$ and higher Secchi depth readings $(0.59 \mathrm{~m}$ $[1.9 \mathrm{ft}], \mathrm{n}=3)$. Average turbidities of the other sites were 61.8 NTUs at TP-3, 55.1 NTUs at TP-2, and 39.8 NTUs at TP-8. However, windy weather was common in early 2012 , with measured wind gusts often up to $64.4 \mathrm{~km} / \mathrm{h}(40 \mathrm{mi} / \mathrm{h})$, peaking at $90.1 \mathrm{~km} / \mathrm{h}(56 \mathrm{mi} / \mathrm{h})$ and $66.0 \mathrm{~km} / \mathrm{h}(41 \mathrm{mi} / \mathrm{h})$ during the March 2012 sampling trip (fig. 3B). Turbidities measured during January/February 2012 and March 2012 sampling trips at TP-6 were 49.8 NTUs (Secchi $=0.41 \mathrm{~m}[1.3 \mathrm{ft}]$ ) and 63.1 NTUs $($ Secchi $=0.30 \mathrm{~m}[1.0 \mathrm{ft}])$, respectively (table 4$)$. Also of note is that the phytoplankton technician recorded that the TP-6 water column samples from January/February 2012 and March 2012 contained "very heavy sediment," whereas phytoplankton samples from other months contained no discernable sediment (BSA Environmental Services, Inc., written commun., 2012).

Turbidity averaged 39.3 NTUs across the 4 sampling stations through the 2013 field trips, and averaged 62.4 NTUs through the 2014 field trips (table 4). Secchi disk measurements across the 4 sampling stations averaged $0.63 \mathrm{~m}(2.1 \mathrm{ft})$ and $0.43 \mathrm{~m}(1.4 \mathrm{ft})$, respectively (fig. 13). Sampling station TP-6 had only slightly higher average water clarity compared to TP-2 and TP-3 (figs. 12, 13, and 14), but water clarity was considerably lower at TP-8 than the other sites from July 2013 to October 2014 (figs. 12, 13, and 14).

\section{Chlorophyll a, Nutrients, Major lons, and Trace Elements}

Analyses of surface water samples included chlorophyll $a$ concentrations, nutrients, ion chemistry, and trace elements. Figure 15 illustrates chlorophyll $a$ concentrations by sampling station $(A)$ and by sampling date $(B)$ from July 2011 to October 2014. The lowest chlorophyll concentrations occurred during October 2013 at TP-3, TP-2, and TP-6 when water temperatures were lower [average $18.4^{\circ} \mathrm{C}\left(65.1^{\circ} \mathrm{F}\right)$ ], water elevation was higher [138.64 m amsl (454.86 ft amsl), turbidity was lower (average 10.1 NTUs), and SAV was dense. The highest chlorophyll $a$ concentrations were consistently measured at TP-8 throughout the study period, with the highest values of 45.7 and 48.2 micrograms per liter (3.8 and 4.0 pounds per gallon) observed in October 2013 and October 2014, respectively (fig. 15).

Nutrients were measured in $\mathrm{mg} / \mathrm{L}$, which is equivalent to $\mathrm{ppm}$. For the entire 2011-12 low water sampling period, means for nutrients were $0.04 \mathrm{mg} / \mathrm{L}$ for TP, $0.74 \mathrm{mg} / \mathrm{L}$ for TN, $0.66 \mathrm{mg} / \mathrm{L}$ for Org-N, $\leq 0.03 \mathrm{mg} / \mathrm{L}$ for $\mathrm{NH}_{3}-\mathrm{N}$, and $0.13 \mathrm{mg} / \mathrm{L}$ for $\mathrm{NO}_{3}+\mathrm{NO}_{2}-\mathrm{N}$ (table 4). Similarly, for the 2013-14 high water sampling period, means for nutrients were $0.06 \mathrm{mg} / \mathrm{L}$ for TP, $0.74 \mathrm{mg} / \mathrm{L}$ for TN, $0.69 \mathrm{mg} / \mathrm{L}$ for Org-N, $0.04 \mathrm{mg} / \mathrm{L}$ for $\mathrm{NH}_{3}-\mathrm{N}$, and $0.04 \mathrm{mg} / \mathrm{L}$ for $\mathrm{NO}_{3}+\mathrm{NO}_{2}-\mathrm{N}$ (table 4 ).

TP- 8 consistently had higher concentrations of TN and TP compared to the other sampling stations, except for July 2011 (fig. 16). Additionally, analyses showed that Org-N accounted for 80 percent or more of the TN in most of the water samples, with the exceptions of samples collected from TP-3 and TP-2 during February and March 2012 and TP-2 during October 2013 and April 2014 (table 4, numbers in red). During those times, the percentage of $\mathrm{NO}_{3}+\mathrm{NO}_{2}-\mathrm{N}$ increased (table 4). All nutrient concentrations were below the Arizona Department of Environmental Quality numeric targets (table 4).

The composition of major ions in water samples collected from Topock Marsh in September/October 2011, October 2013, and September/October 2014 are illustrated using Stiff diagrams (figs. 17-19). The illustrations reveal similar spatial patterns, with some minor differences. In 2011, when inflows had been restricted for months, the two upstream stations (TP-3 and TP-2) were markedly different in ionic composition and concentration from the two downstream stations (TP-6 and TP-8). The ionic concentrations of TP- 6 and TP- 8 clearly declined from 2011 to 2014 as inflows into the marsh increased. The ionic concentrations of TP-2 and TP-3 changed only slightly between the sampling periods and were markedly similar to the Colorado River water measured at a nearby station (see inset in figs. 18 and 19). 

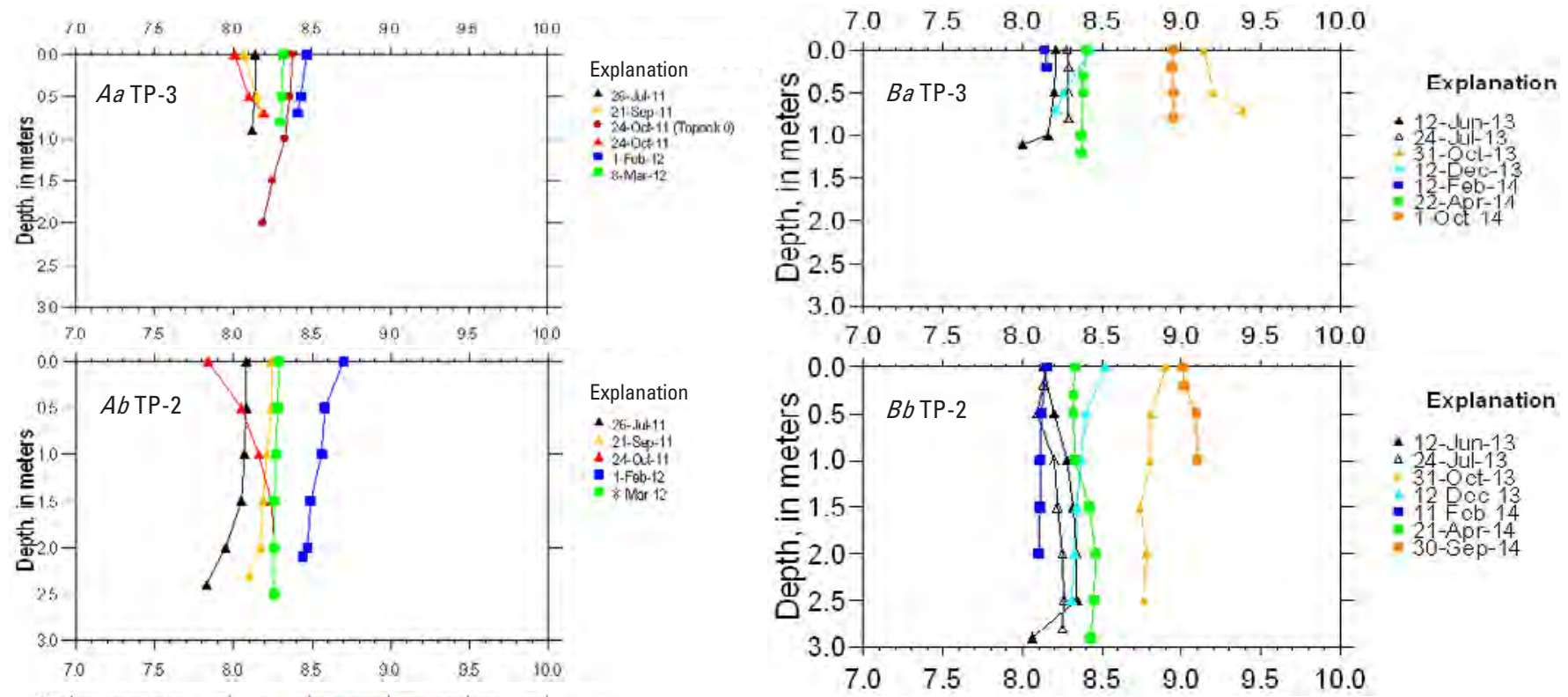

Explanation
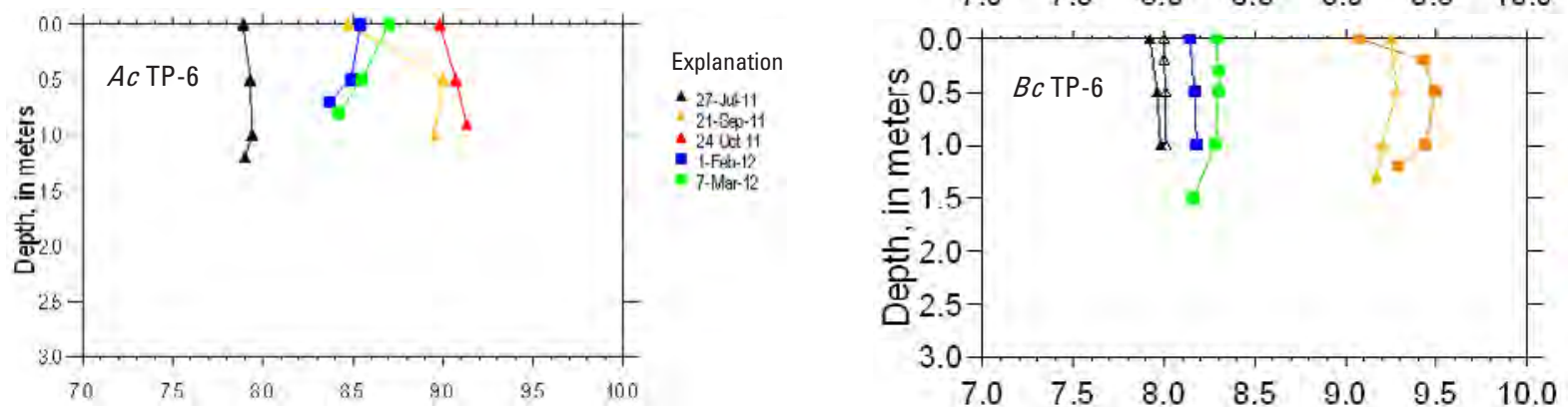

- 12-Jun-13

$24-J u l-13$

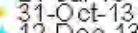

- $12 \mathrm{Pcc} 13$

21-Apr-14

30-5ep-14
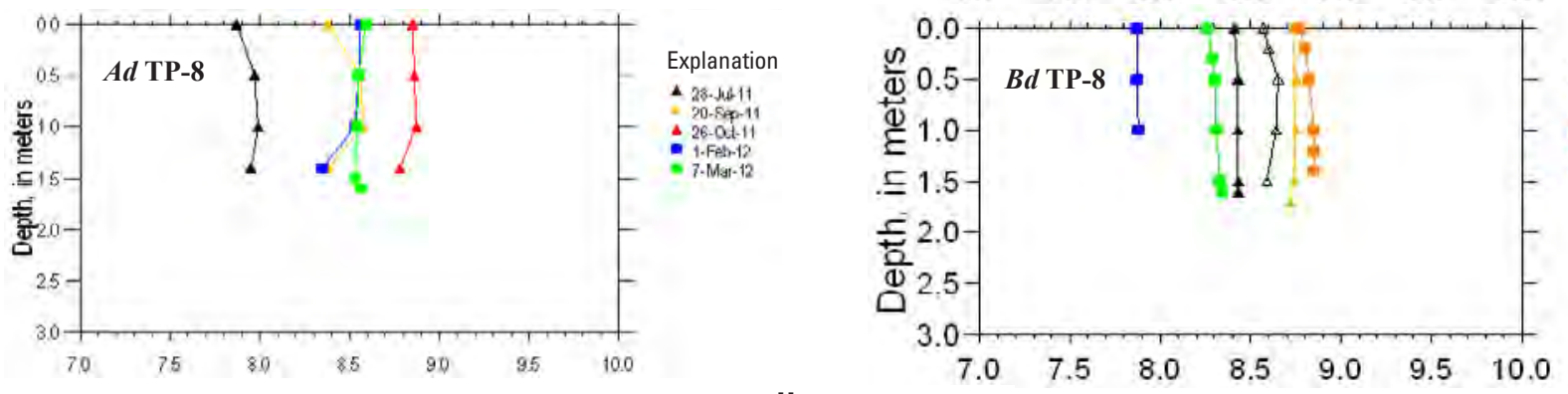

Explanation

$\mathrm{pH}$

Explanation
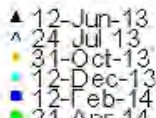

30-Sep-14

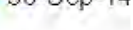

$12-\operatorname{Jun}-13$

- 1 -

1200013

$=22-\cot -14$

Figure 8. Depth profiles of $\mathrm{pH}$ in Topock Marsh during 2011 and 2012 ( $A$, charts on left) and 2013 and 2014 ( $B$, charts on right) at sampling stations TP-3, TP-2, TP-6, and TP-8. Stations are displayed in upstream to downstream order, top to bottom, but numbering is not sequential. Colors represent season (blue = winter, green = spring, black = summer, yellow or red = fall) and symbols represent year (• or $\boldsymbol{\Delta}=2011$ and 2013, $\mathbf{\square}=2012$ and 2014). 

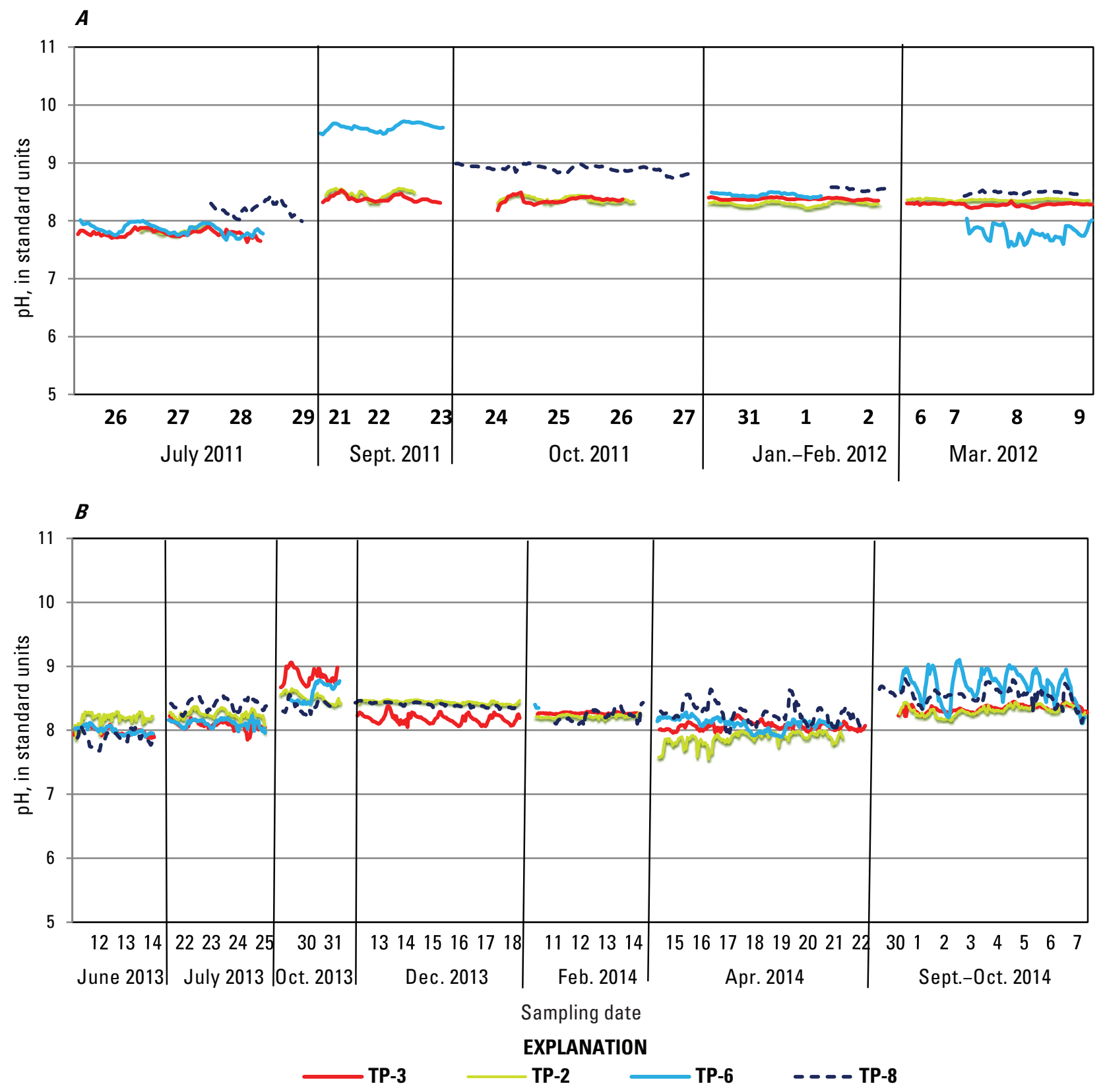

Figure 9. Diurnal pH in Topock Marsh at sampling stations TP-3, TP-2, TP-6, and TP-8 during site visits from July 2011 to March $2012(A)$ and from June 2013 to September/October $2014(B)$. Stations are displayed in upstream to downstream order, but numbering is not sequential. 

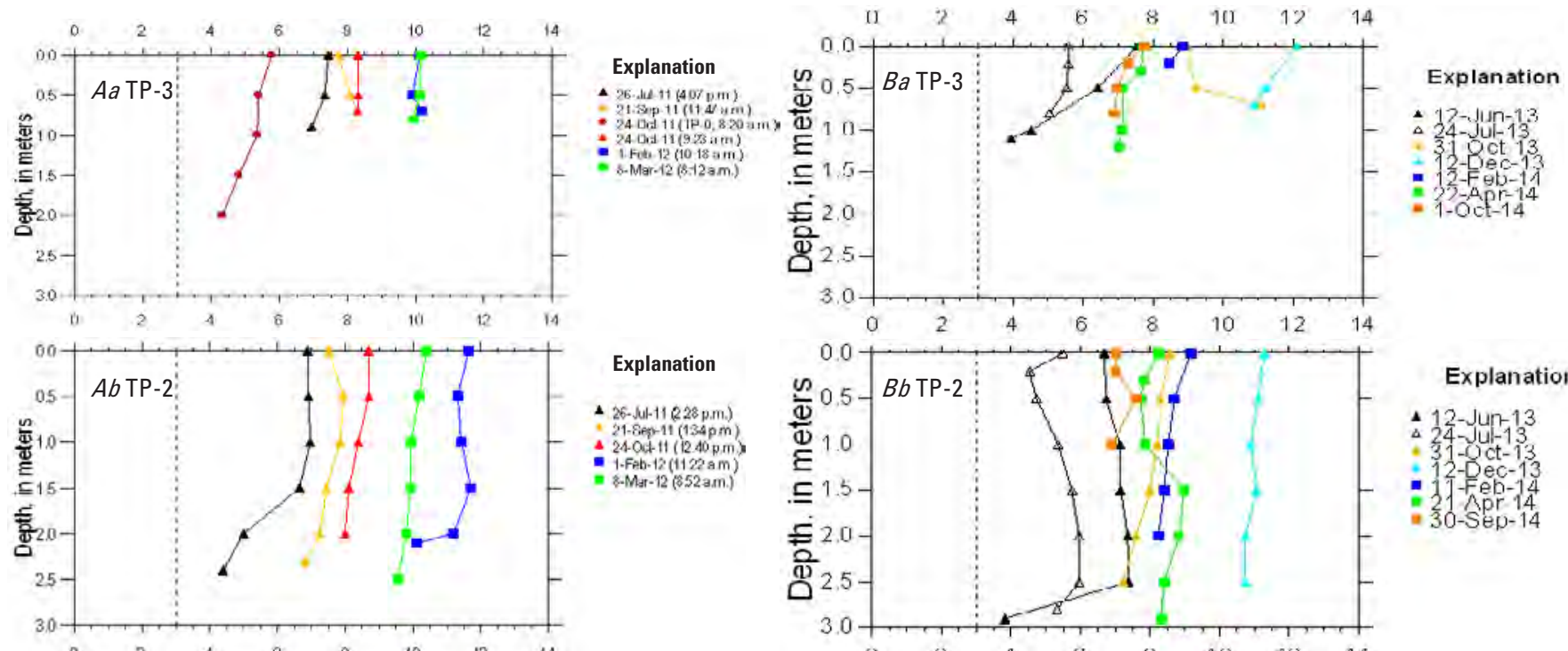

Explanation

- $26 .-(1-11(228 \mathrm{pm})$ 24. 24 t 11 (12 $40 \mathrm{pm})$ - Fablit (1122am) $=8-\operatorname{Mar}-12(052 \mathrm{am})$
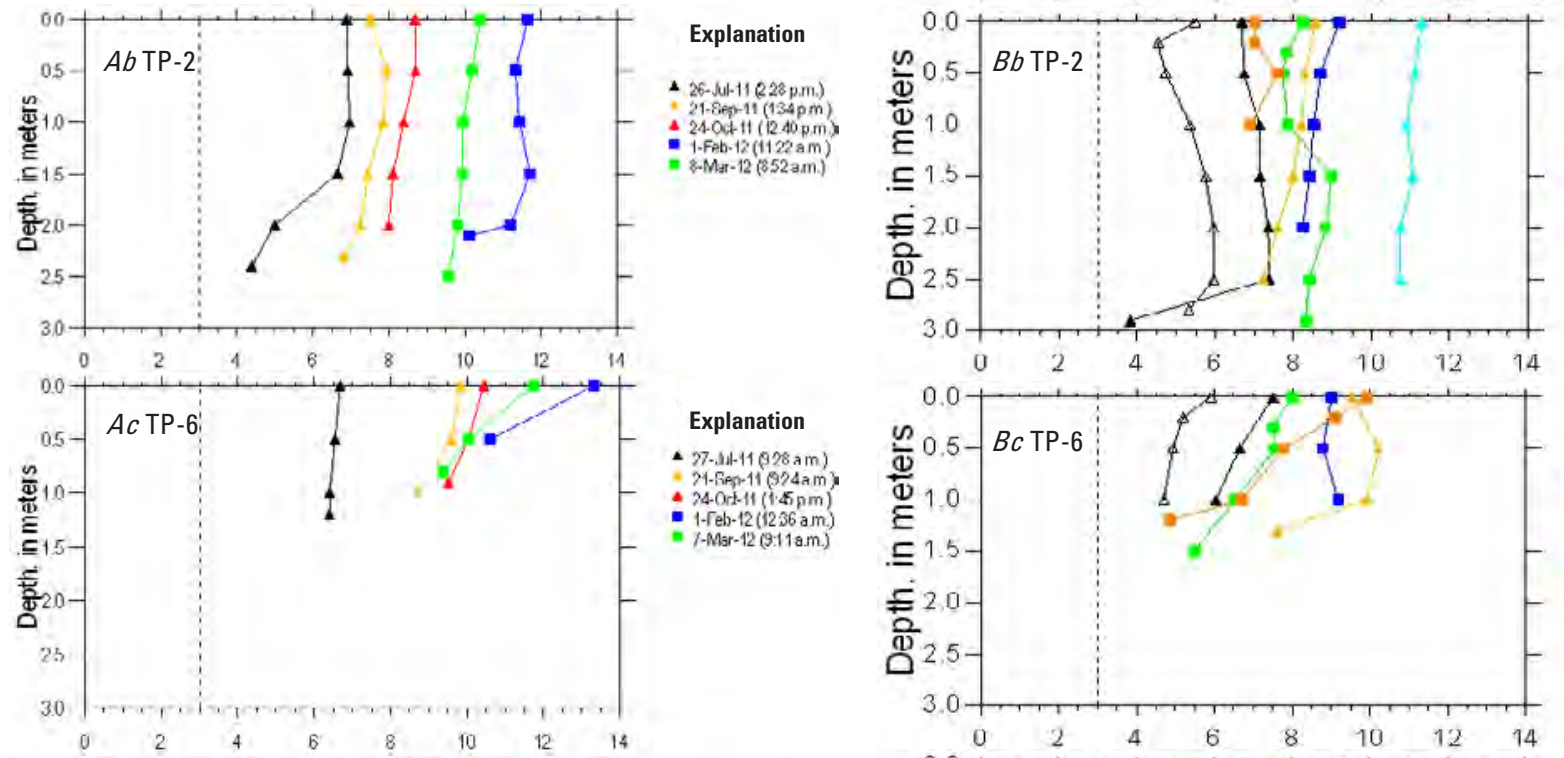

Explanation

12 -Jun-13

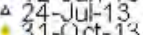

12-0t-13

- $11-\mathrm{Feb}-14$

- 30 -sep-14
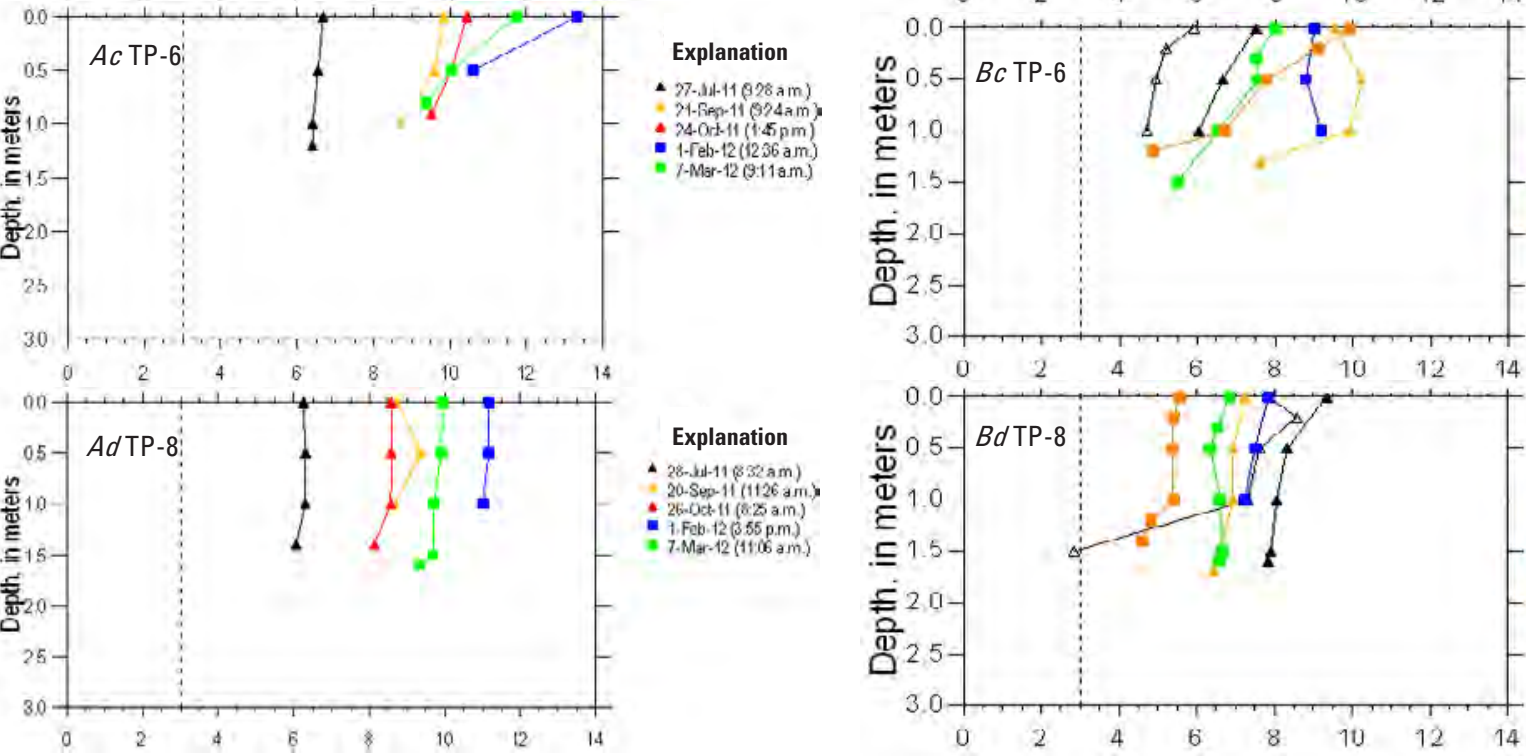

Explanation

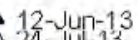

24 ul-13

$31-0 \mathrm{ct}-13$
$12-0 \mathrm{ec}-13$

30 - Apr -14

sop 14

Dissolved oxygen, in milligrams per liter

Figure 10. Depth profiles of dissolved oxygen in Topock Marsh during 2011 and 2012 ( $A$, charts on left) and 2013 and 2014 ( $B$, charts on right) at sampling stations TP-3, TP-2, TP-6, and TP-8. Stations are displayed in upstream to downstream order top to bottom, but numbering is not sequential. Colors represent season (blue = winter, green = spring, black = summer, yellow or red = fall) and symbols represent year ( $\bullet$ or $\boldsymbol{\Delta}=2011$ and 2013, $\mathbf{\square}=2012$ and 2014). The vertical dashed line at 3.0 milligrams per liter dissolved oxygen indicates the U.S. Environmental Protection Agency (EPA) 1-day minimum criteria for "other life stages" of warm water fish (EPA, 1986a). 

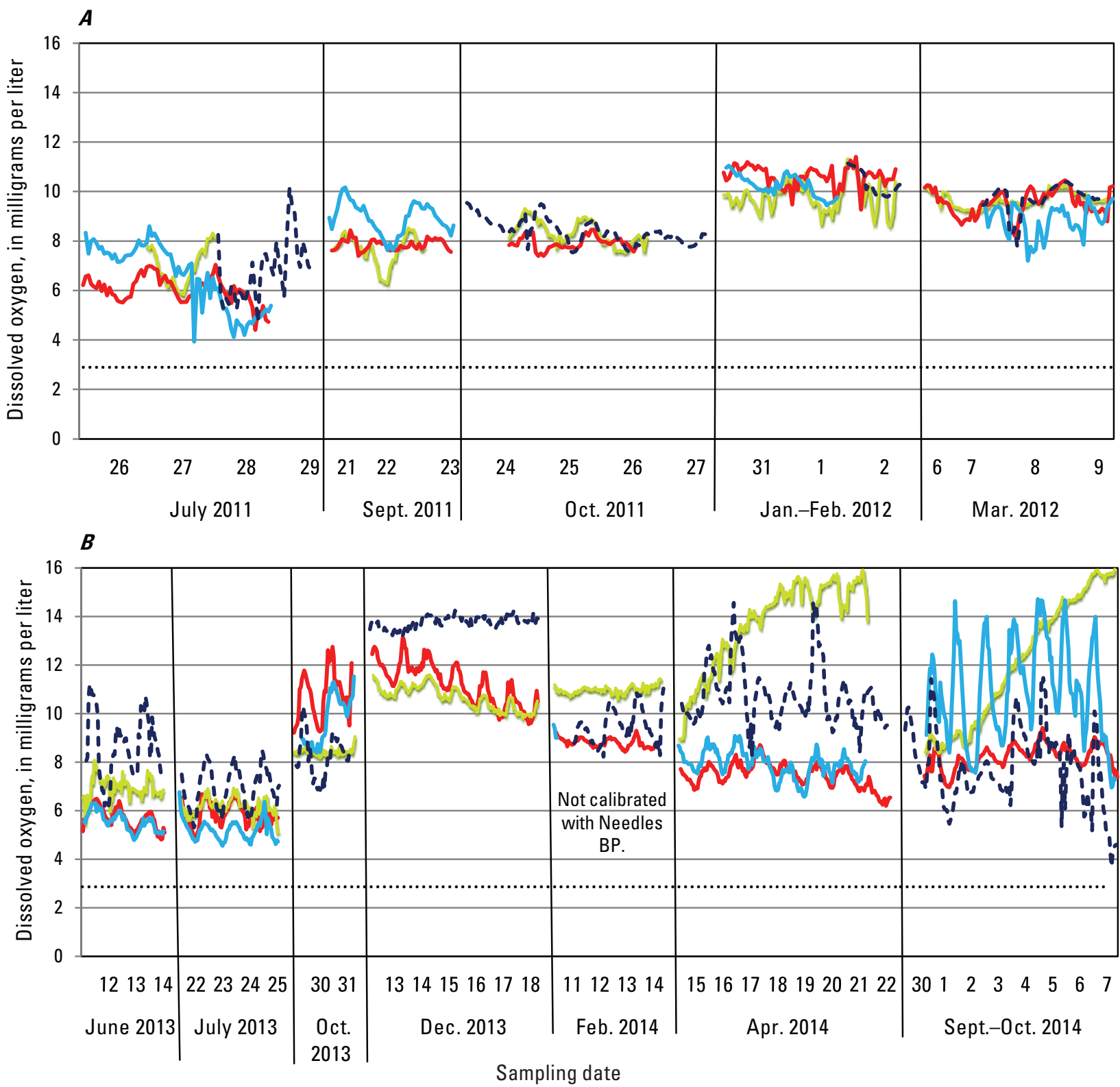

EXPLANATION

TP-3

TP-2

TP-6

TP-8

Figure 11. Diurnal dissolved oxygen in Topock Marsh at sampling stations TP-3, TP-2, TP-6, and TP-8 during site visits from July 2011 to March $2012(A)$ and from June 2013 to September/October $2014(B)$. Stations are displayed in upstream to downstream order, but numbering is not sequential. The dotted horizontal line illustrates the minimum threshold of 3.0 milligrams per liter established as the one-day criterion for "other life stages" of warm water fish by the U.S. Environmental Protection Agency (EPA). (EPA, 1986a). 


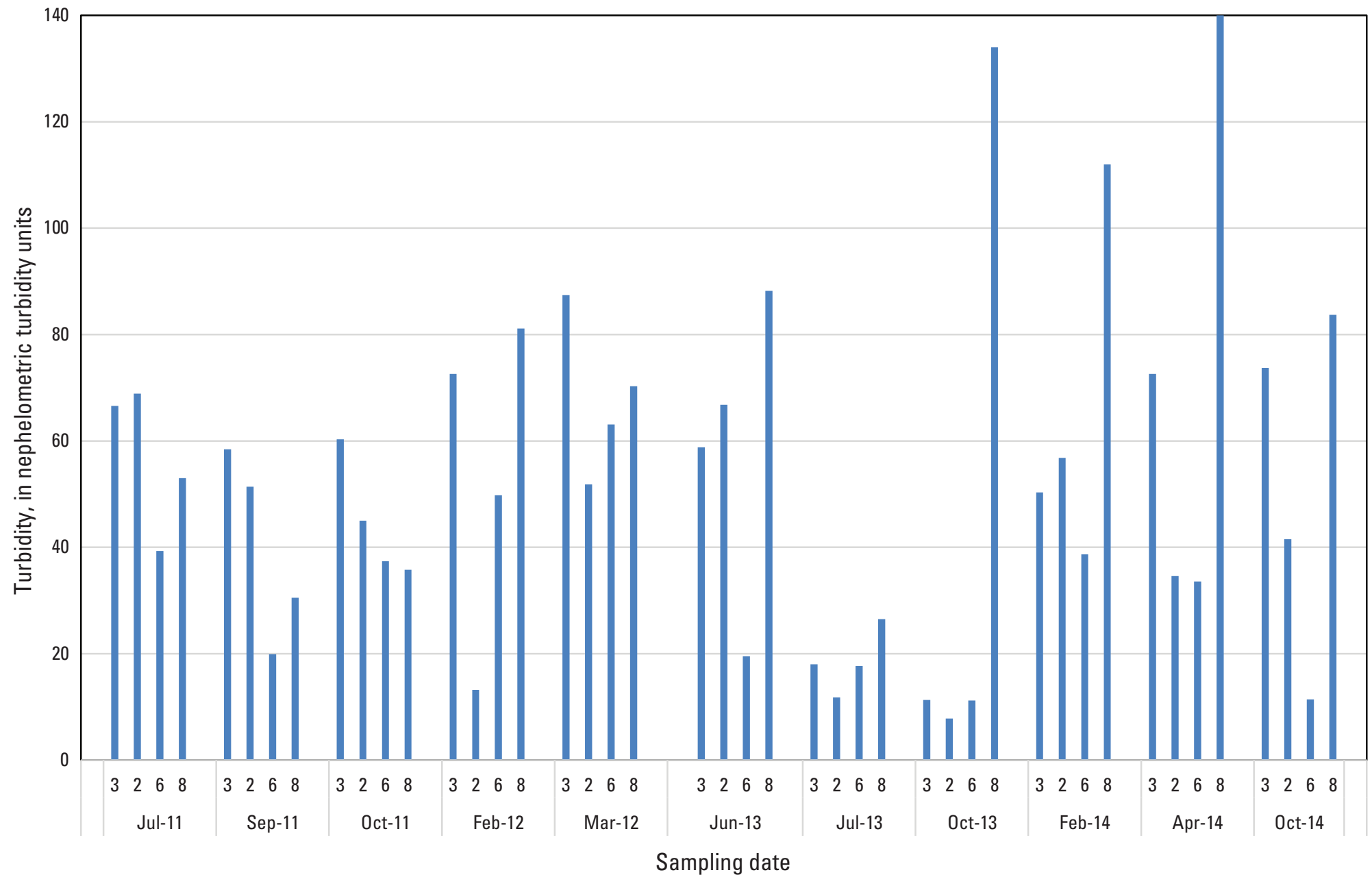

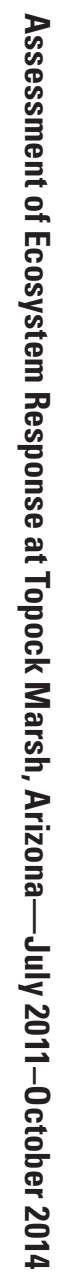

Figure 12. Surface water turbidity in Topock Marsh at sampling stations TP-3 (3), TP-2 (2), TP-6 (6), and TP-8 (8) from July 2011 to 0ctober 2014. Stations are displayed in upstream to downstream order, but numbering is not sequential. 

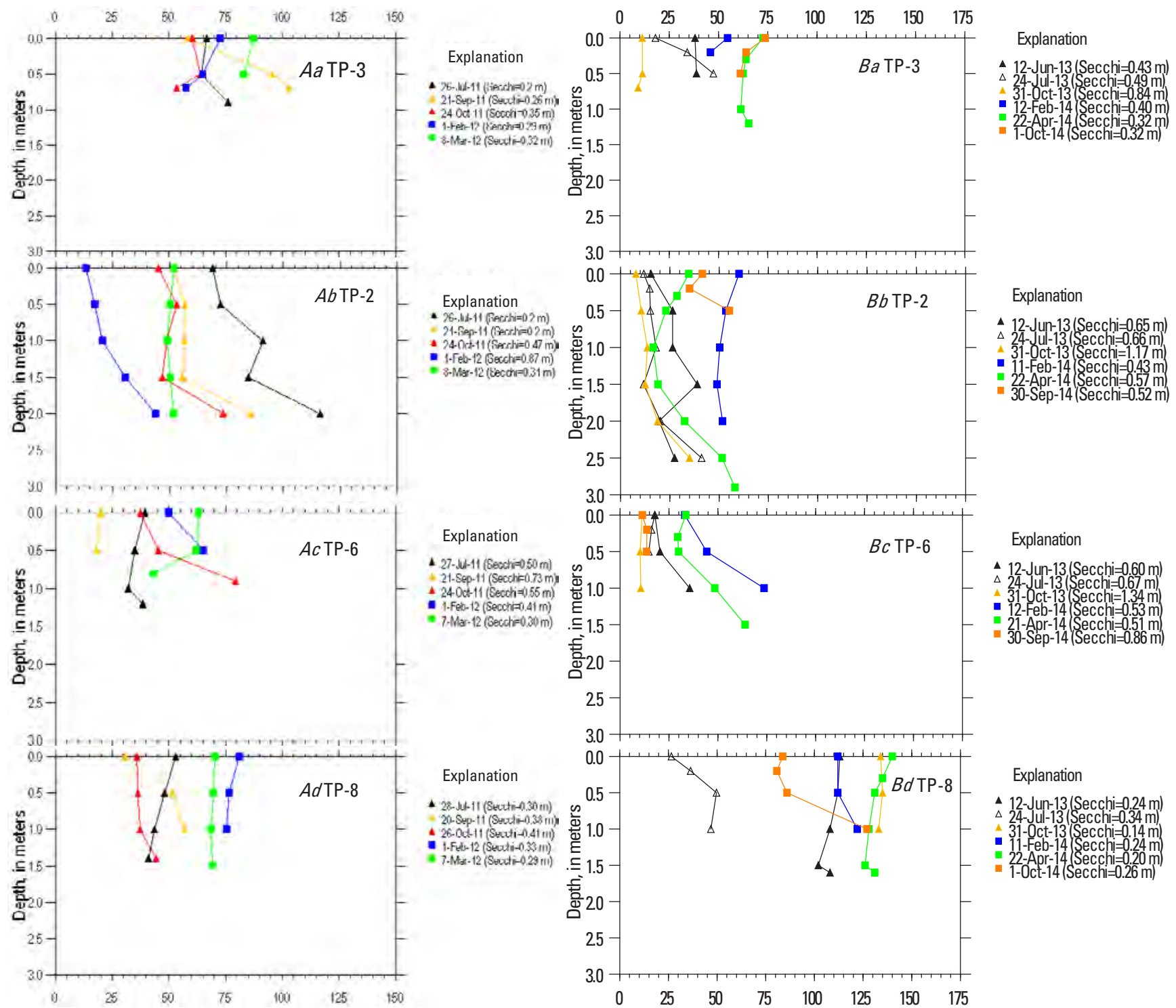

Turbidity, in nephelometric turbidity units

Figure 13. Depth profiles of turbidity and concurrent Secchi depths in Topock Marsh during 2011 and 2012 ( $A$, charts on left) and 2013 and 2014 (B, charts on right) at sampling stations TP-3, TP-2, TP-6, and TP-8. Stations are displayed in upstream to downstream order, top to bottom, but numbering is not sequential. Colors represent season (blue = winter, green = spring, black = summer, yellow or red = fall) and symbols represent year ( $\Delta=2011$ and 2013, $\mathbf{\square}=2012$ and 2014). 


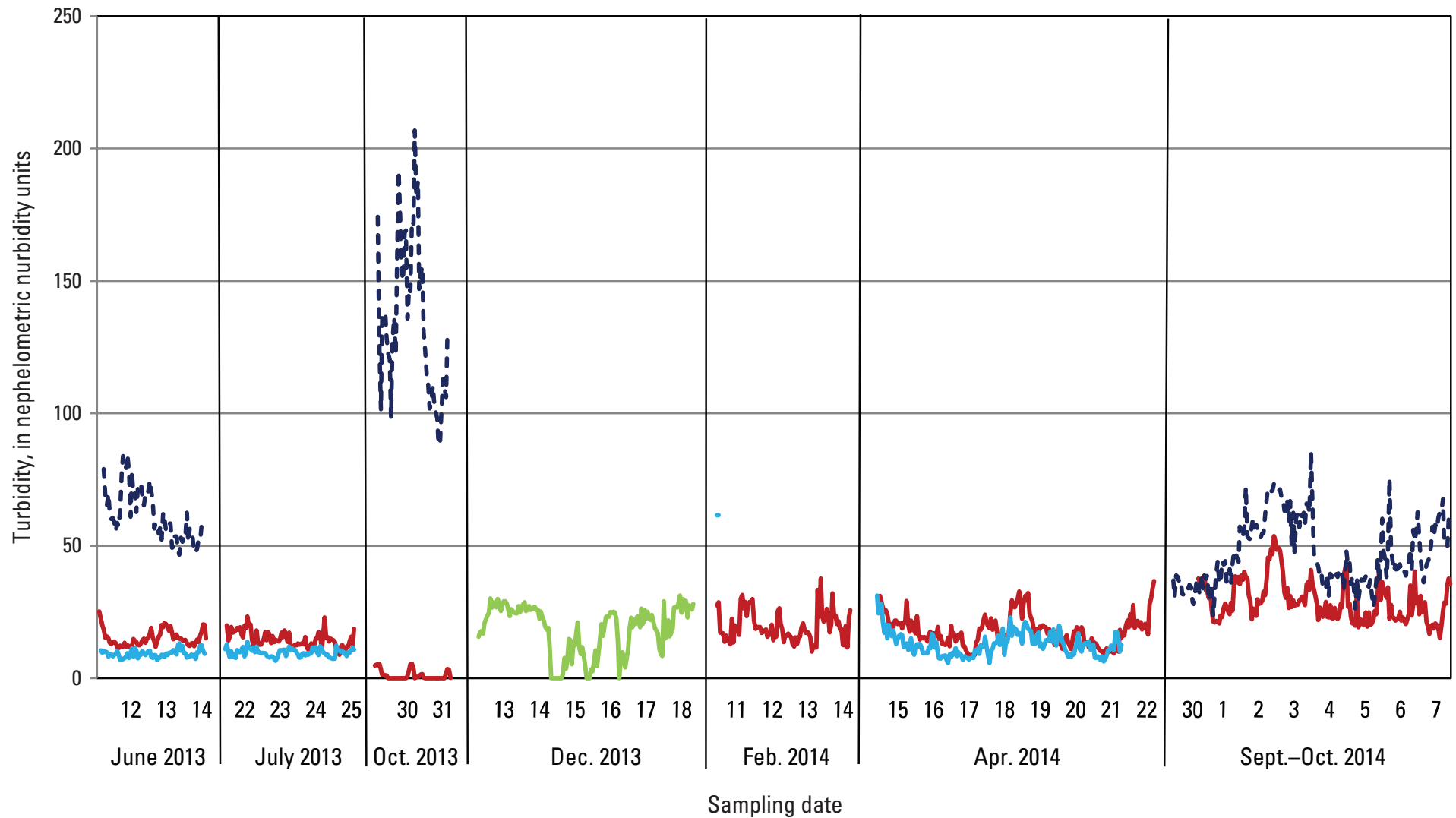

EXPLANATION

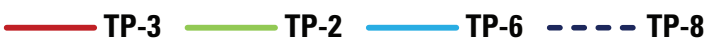

Figure 14. Diurnal turbidity in Topock Marsh at sampling stations TP-3, TP-2, TP-6, and TP-8 during site visits from June 2013 to September/ October 2014. 


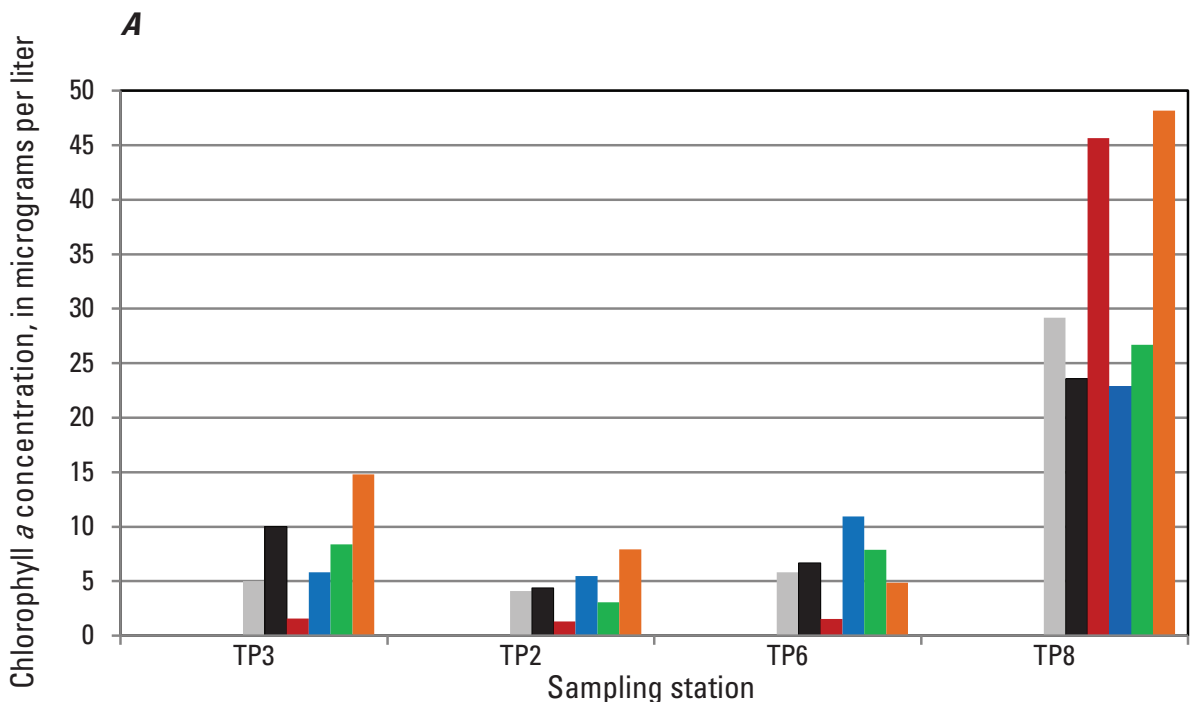

EXPLANATION

- Jul 2011 Sept 2011

口 Jul 2013 - Oct 2013

- Oct 2011 Jan-Feb 2012 Mar 2012

- Sept-0ct 2014

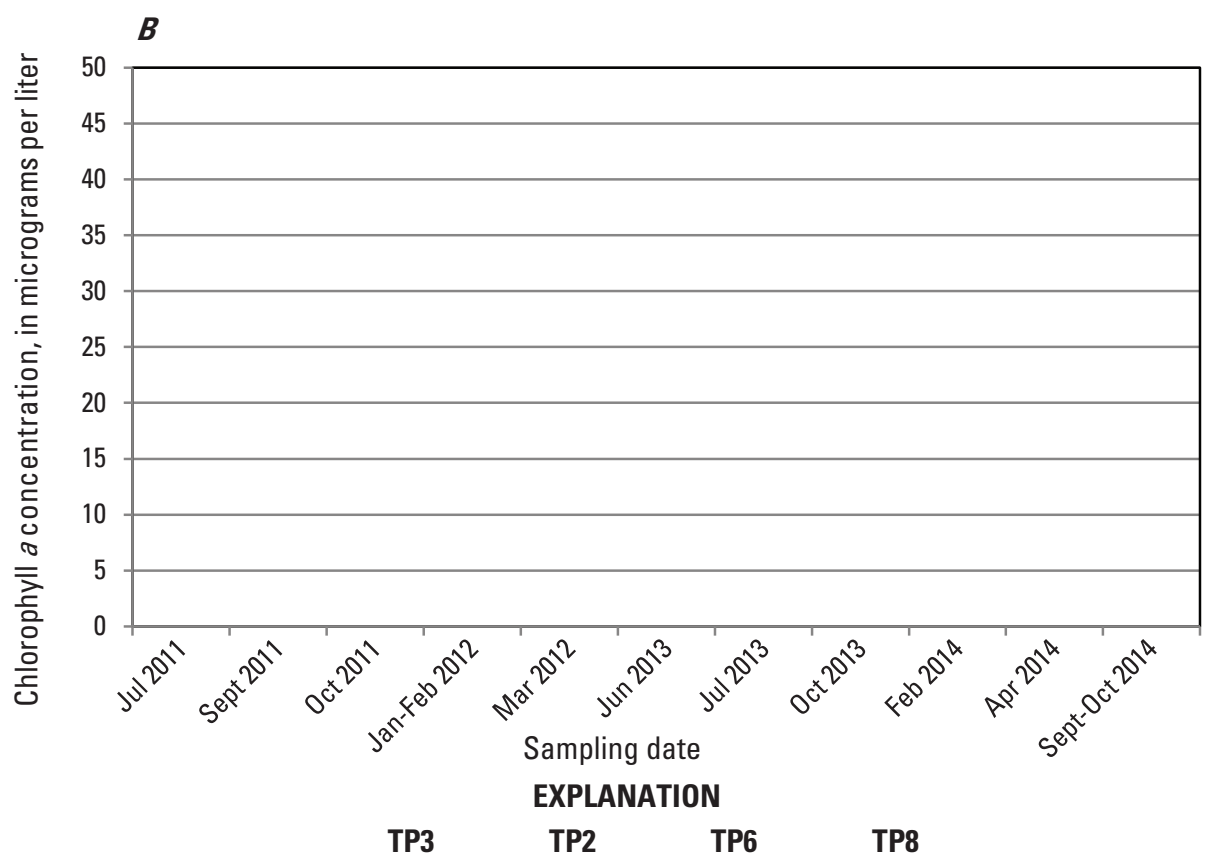

Figure 15. Surface water chlorophyll a concentrations in Topock Marsh at sampling stations TP-3, TP-2, TP-6, and TP-8 from July 2011 to October 2014, shown by sampling station (A) and by sampling date $(B)$. Stations are displayed in upstream to downstream order, but numbering is not sequential. 


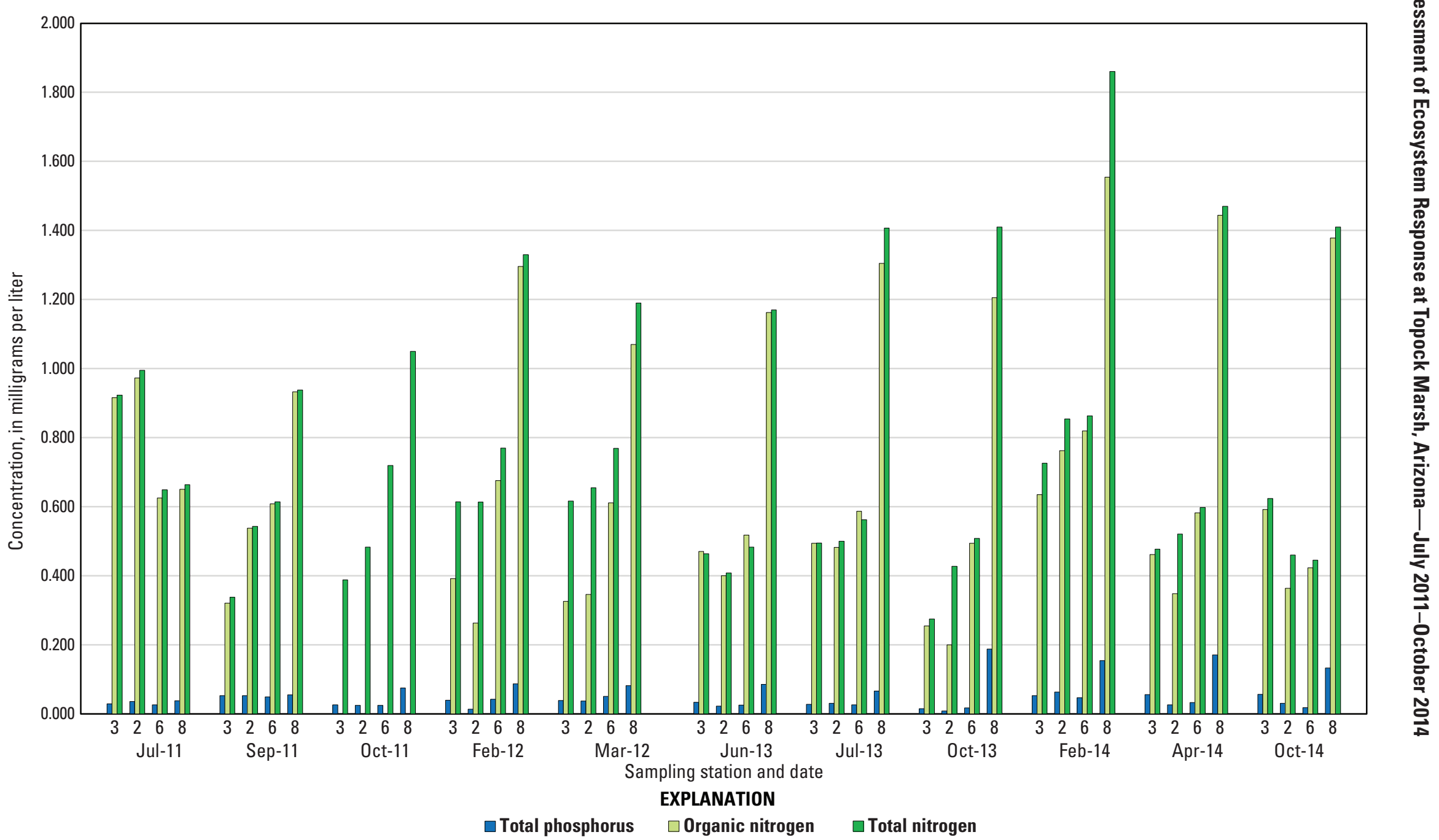

Figure 16. Concentration of total phosphorus, organic nitrogen, and total nitrogen in Topock Marsh at sampling stations TP-3 (3), TP-2 (2), TP-6 (6), and TP-8 (8) during site visits from July 2011 to September/October 2014. Stations are displayed in upstream to downstream order, but numbering is not sequential. 

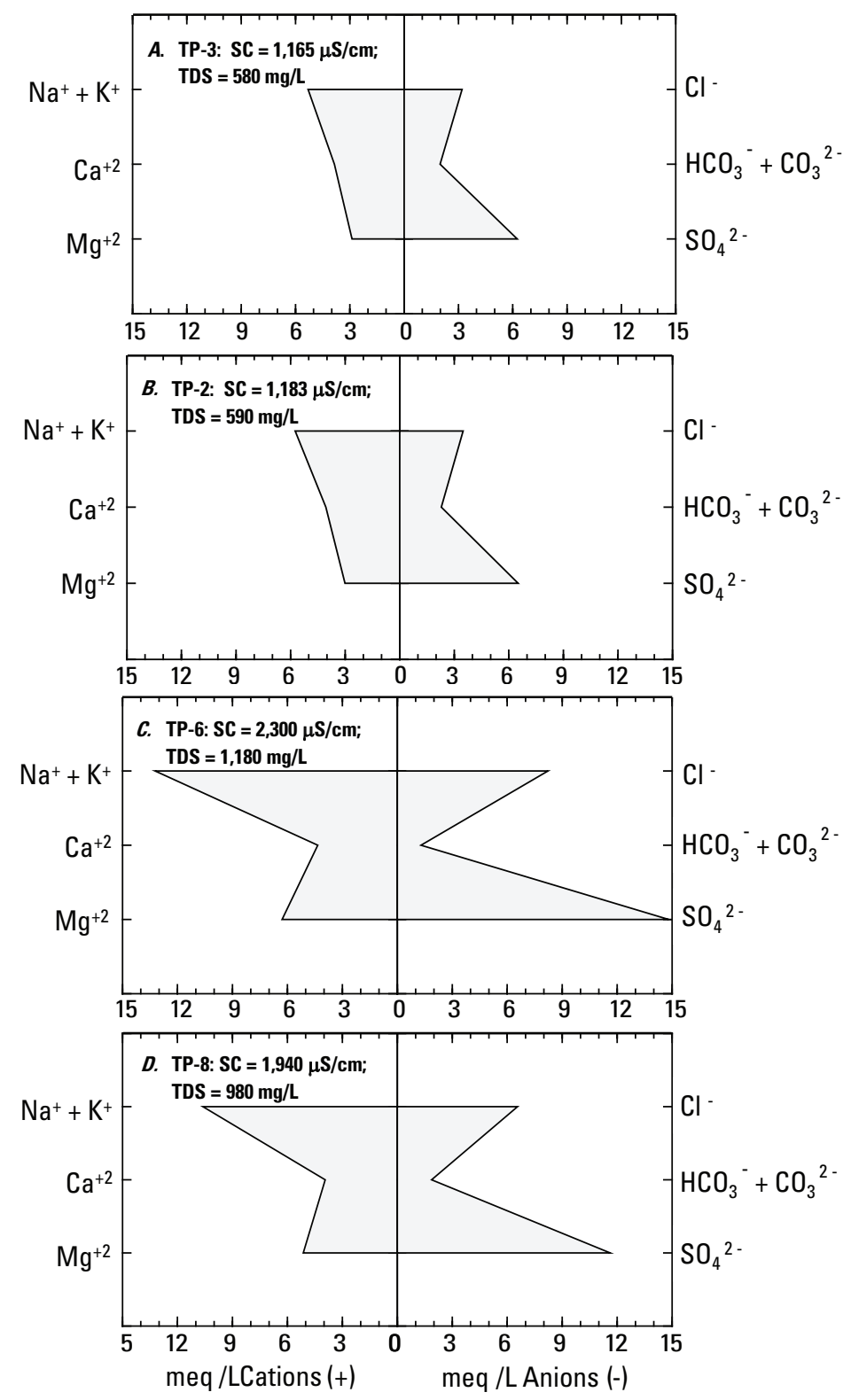

Figure 17. Stiff diagrams showing distribution of major ion chemistry during September/October 2011 in Topock Marsh at sampling stations TP-3 $(A)$, TP-2 $(B)$, TP-6 $(C)$, and TP-8 $(D)$. Stations are displayed in upstream to downstream order, but numbering is not sequential. Carbonate and bicarbonate concentrations were calculated from alkalinity. Specific conductance (SC) measured in microsiemens per centimeter $(\mu \mathrm{S} / \mathrm{cm})$, total dissolved solids (TDS) measured in milligrams per liter $(\mathrm{mg} / \mathrm{L})$, and ion concentrations measured in milliequivalents per liter (meq/L). ( $\mathrm{Na}$, sodium; $\mathrm{K}$, potassium; Cl, chlorine; $\mathrm{Ca}$, calcium; $\mathrm{HCO}_{3^{\prime}}$, bicarbonate; $\mathrm{CO}_{3^{\prime}}$ carbonate; $\mathrm{Mg}$, magnesium; $\mathrm{SO}_{4^{\prime}}$, sulfate) 


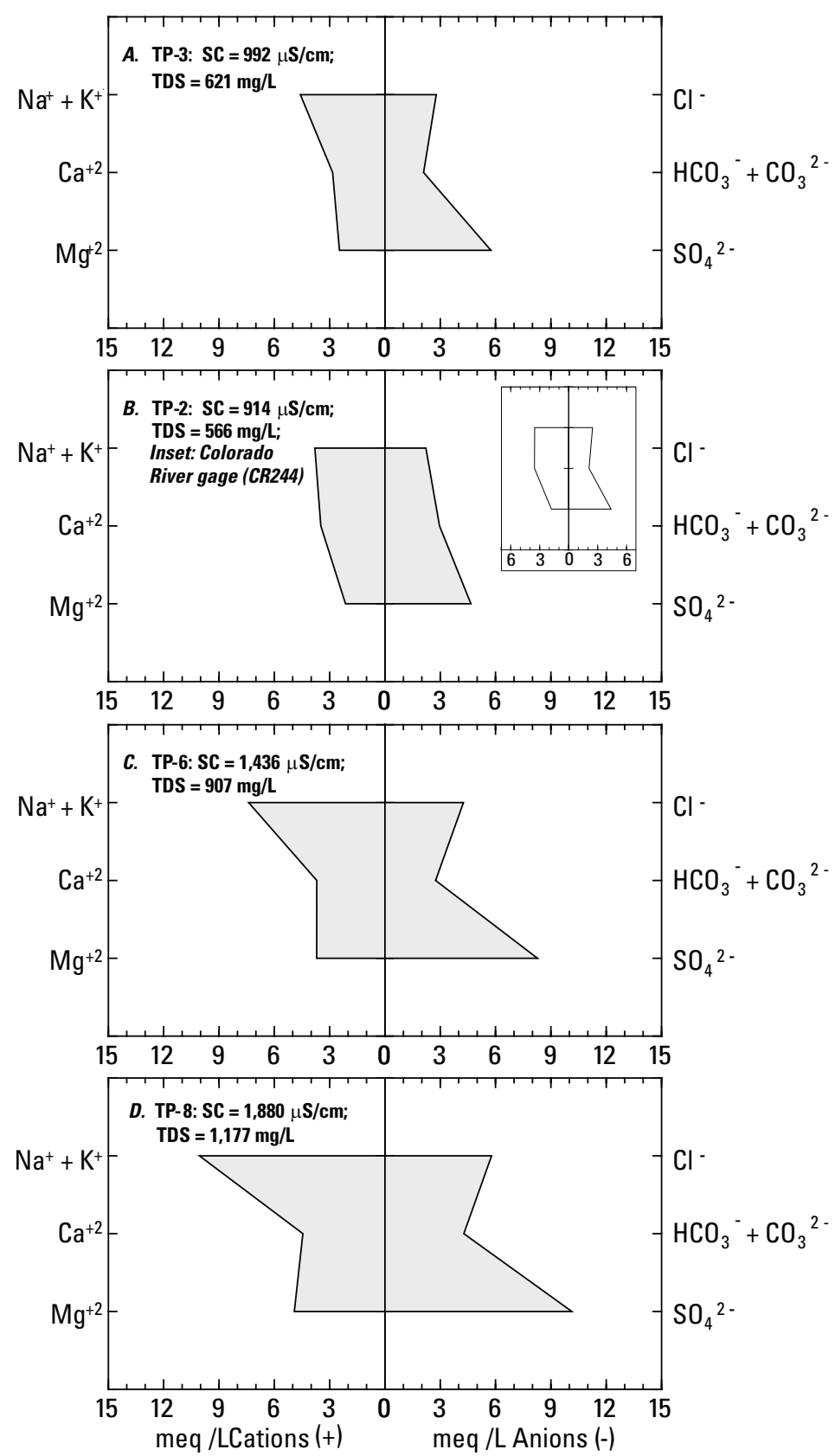

Figure 18. Stiff diagrams showing distribution of major ion chemistry in October 2013 in Topock Marsh at sampling stations TP-3 (A), TP-2 (B), TP-6 $(C)$, and TP-8 $(D)$. Stations are displayed in upstream to downstream order, but numbering is not sequential. Carbonate and bicarbonate concentrations were calculated from alkalinity. Data from Colorado River Gage (at CR 244, 2 kilometers upstream of Fire Break Canal, in December 2013) were provided by Scott O'Meara of the Bureau of Reclamation. Specific conductance (SC) measured in microsiemens per centimeter $(\mu \mathrm{S} / \mathrm{cm})$, total dissolved solids (TDS) measured in milligrams per liter ( $\mathrm{mg} / \mathrm{L})$, and ion concentrations measured in milliequivalents per liter (meq/L). ( $\mathrm{Na}$, sodium; $\mathrm{K}$, potassium; $\mathrm{Cl}$, chlorine; $\mathrm{Ca}$, calcium; $\mathrm{HCO}_{3^{\prime}}$, bicarbonate; $\mathrm{CO}_{3^{\prime}}$ carbonate; $\mathrm{Mg}$, magnesium; $\mathrm{SO}_{4^{\prime}}$, sulfate) 

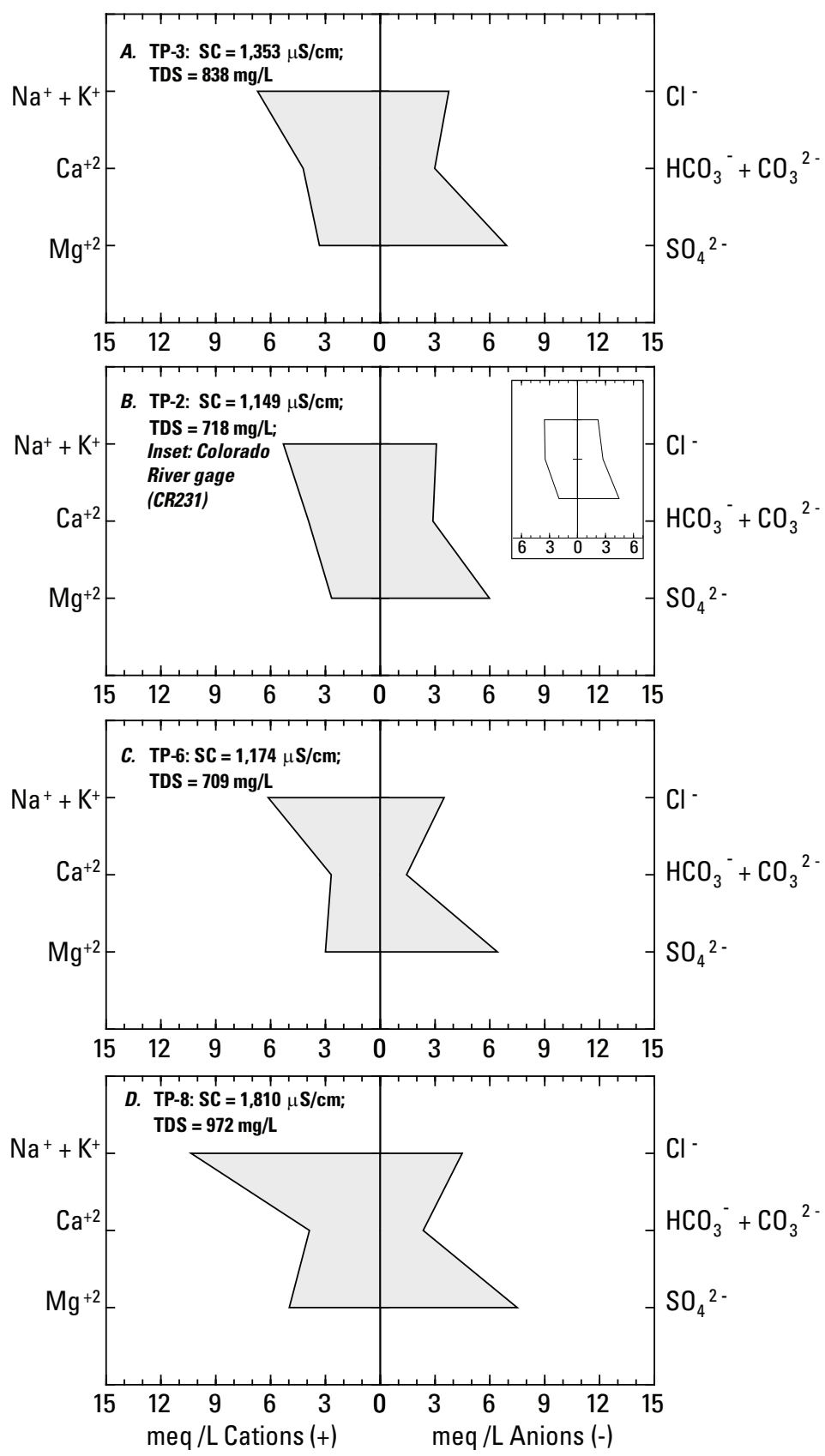

Figure 19. Stiff diagrams showing distribution of major ion chemistry for September 30-0ctober 1, 2014, in Topock Marsh at sampling stations TP-3 $(A)$, TP-2 $(B)$, TP-6 $(C)$, and TP-8 $(D)$. Stations are displayed in upstream to downstream order, but numbering is not sequential. Data from Colorado River Gage (at CR231, 6 kilometers below South Dike of Topock Marsh, in September 2014) were provided by Scott O'Meara of the Bureau of Reclamation. Specific conductance (SC) measured in microsiemens per centimeter $(\mu \mathrm{S} / \mathrm{cm})$, total dissolved solids (TDS) measured in milligrams per liter $(\mathrm{mg} / \mathrm{L})$, and ion concentrations measured in milliequivalents per liter (meq/L). ( $\mathrm{Na}$, sodium; $\mathrm{K}$, potassium; $\mathrm{Cl}$, chlorine; $\mathrm{Ca}$, calcium; $\mathrm{HCO}_{3^{\prime}}$ bicarbonate; $\mathrm{CO}_{3^{\prime}}$ carbonate; $\mathrm{Mg}$, magnesium; $\mathrm{SO}_{4^{\prime}}$, sulfate) 
Trace elemental concentrations were similar between all sampling stations and dates (October 2011, June 2013, and September/October 2014). These concentrations were well below the toxicity standards determined by the Arizona Department of Environmental Quality for aquatic and wildlife use (see table 5).

\section{Long-Term Water Chemistry}

Long-term water chemistry data for Topock Marsh (from late 1983 through early 2015) are provided in appendix 1 for comparison purposes. TP-8 was our nearest sampling station to Reclamation's long-term sampling location at the marsh's outlet structure in the South Dike (fig. 1). To give an example of these data for making comparisons, we have plotted the historical SC data, because changes in $\mathrm{SC}$ can be indicative of major changes in the amount and mobility of ions in the water. Thus, this plot illustrates large variations in SC between seasons and years within Topock Marsh (fig. 20).

\section{Sediment Chemistry}

A great deal of variation in sediment chemistry was found among the sediments collected from the four stations during the three collection years of 2011, 2013, and 2014 (table 6). Average nutrient concentrations in the sediment were higher in the October 2011 samples than either the July 2013 or October 2014 samples, and large variations in soil texture existed between sampling dates.

\section{Plant Chemistry}

Chemical elements obtained from plant samples are provided in table 7 as percentages and concentrations in milligrams per kilogram ( $\mathrm{mg} / \mathrm{kg}$ ), which is equivalent to ppm. Because of the unavailability of submerged vegetation (spiny naiad or Eurasian watermilfoil) in July 2013 and the presence of deep water in the marsh in October 2014, the plant material available to be collected for analyses was not the same in July 2013 and October 2014. Therefore, the results of the analyses varied quite a bit, especially when comparing the percent dry matter of the emergent vegetation, California bulrush (22.3-29.2 percent), to the SAV species, spiny naiad and Eurasian watermilfoil (4.4-8.9 percent). Because the submerged species contained a higher percentage of water in their stems and leaves than the California bulrush, they had lower dry matter percentages (in other words, higher water percentages) and the submerged species contained higher percentages, or concentrations, of most elements measured. The exceptions were $\mathrm{B}, \mathrm{NO}_{3}-\mathrm{N}$, and Se.
Mean B concentration in the California bulrush was 2.7 times higher than in the average SAV and Eurasian watermilfoil contained the smallest amount $(1.5 \mathrm{mg} / \mathrm{kg})$. The mean concentration of $\mathrm{NO}_{3}-\mathrm{N}$ in five California bulrush samples $(28.9 \mathrm{mg} / \mathrm{kg})$ was three times higher than the SAV samples (mean $=8.8 \mathrm{mg} / \mathrm{kg}$ ). Selenium concentrations were low throughout all plant samples; however, concentrations in the California bulrush were 320 times higher than in the SAV samples, with a mean of $0.96 \mathrm{mg} / \mathrm{kg}$ in the California bulrush compared to $0.003 \mathrm{mg} / \mathrm{kg}$ in the SAV (table 7).

There were also large differences in concentrations of some elements between sampling stations for the same plant species. For example, Mn ranged from 96.5 to $431 \mathrm{mg} / \mathrm{kg}$ in California bulrush and from 126 to $650 \mathrm{mg} / \mathrm{kg}$ in spiny naiad samples. Likewise, aluminum, $\mathrm{Cu}$, and $\mathrm{Fe}$ concentrations were higher in plant material collected near TP-2 than at the other locations.

\section{Biological Characteristics}

\section{Aquatic Vegetation}

\section{Submerged Aquatic Vegetation}

The SAV coverage ratings taken at each transect, as well as the water depths and turbidity measurements at each point, are tabularized in table 8 and sampling transects are illustrated in figure 21. Table 9 provides a summary of the presence ratios of the plant species; the ratios are the number of sampling points along a transect that contained at least one submerged aquatic plant divided by the total number of sampling points along a transect. The indigenous spiny naiad was the dominant submerged plant species throughout Topock Marsh during the entire investigation period (2011-14). Sago pondweed (Stuckenia pectinata), also indigenous and highly desired by waterfowl, was second in dominance but far less than spiny naiad in presence and coverage (tables 8 and 9). Our initial observations of SAV coverage in July 2011 suggested submerged plant density was low to moderate in shallow (41-89 cm [1.3-2.9 ft] deep), protected areas of the marsh, such as in the vicinity of TP-6 (table 8). However, both species were rare in deeper and more exposed areas, such as along the eastern half of the transect between TP-1 and TP-7 (fig. 21). By September/October 2011, spiny naiad and sago pondweed had grown denser and were more common throughout the shallow protected areas (that is, parts of TP-3, TP-6, TP-5, TP-8, and TP-9), but remained less dense in the open, exposed areas. By the end of January and into March 2012, virtually no spiny naiad was observed in the marsh and only five individual sprigs of sago pondweed were noted (tables 8 and 9). 
Table 5. Elemental analyses of water at four sampling stations in Topock Marsh during October 2011, July 2013, and September/October 2014.

[All samples were taken at the sampling stations from just below the water surface. As, arsenic; B, boron; $\mathrm{Cd}$, cadmium; $\mathrm{Cr}$, chromium; $\mathrm{Cu}$, copper; $\mathrm{F}$, fluoride, $\mathrm{Fe}$, iron; $\mathrm{Hg}$, mercury; Mn, manganese; $\mathrm{Pb}$, lead; Se, selenium; $\mathrm{Zn}$, zinc; $\mu \mathrm{g} / \mathrm{L}$, micrograms per liter; TP, sampling station; NA, not available; NWQL, National Water Quality Laboratory; ADEQ, Arizona Department of Environmental Quality]

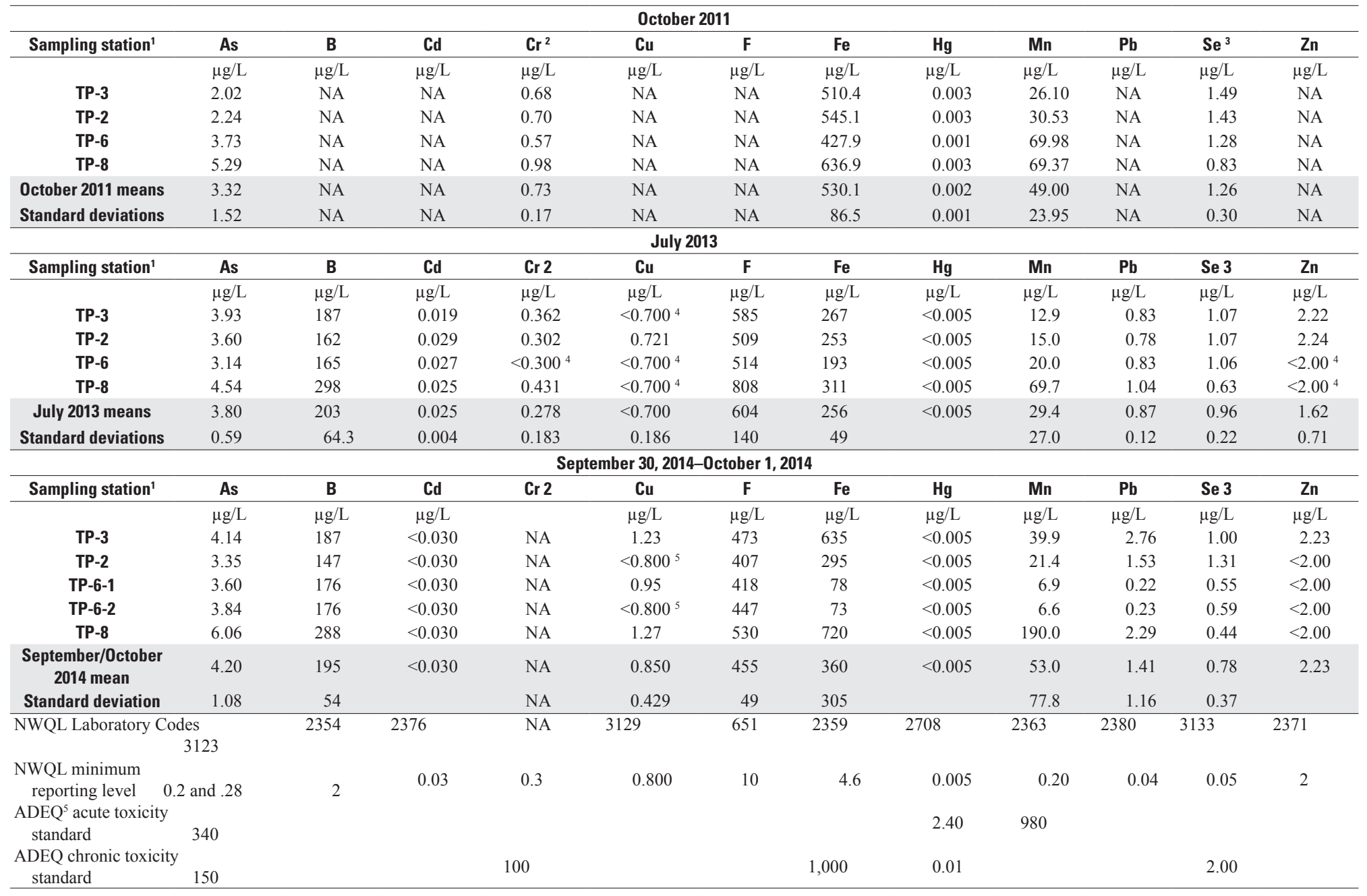

${ }^{1}$ Sampling stations are displayed in upstream to downstream order.

${ }^{2}$ Chronium analyses in 2014 were not done due to low levels in 2013 and the cost of analyses.

${ }^{3}$ The U.S. Environmenntal Protection Agency (EPA) is reviewing selenium standards and only chronic criteria (5.0 ug/L for freshwater) are available on their online compilation (EPA, 2012). In a draft report, the EPA (2004) recommends acute criteria should be based on the relative proportion of selenite, and chronic criteria should be based on selenium concentrations within fish tissue.

${ }^{4}$ Means including "less than $(<)$ " values are calculated using half of the detection limits for analyzed parameters.

${ }^{5}$ The standards recommended by the Arizona Department of Environmental Quality (ADEQ) are specific to warmwater lakes and reservoirs designated for aquatic and wildlife use. Ranges apply to peak season (April to October for warmwater lakes [ADEQ, 2009]). 


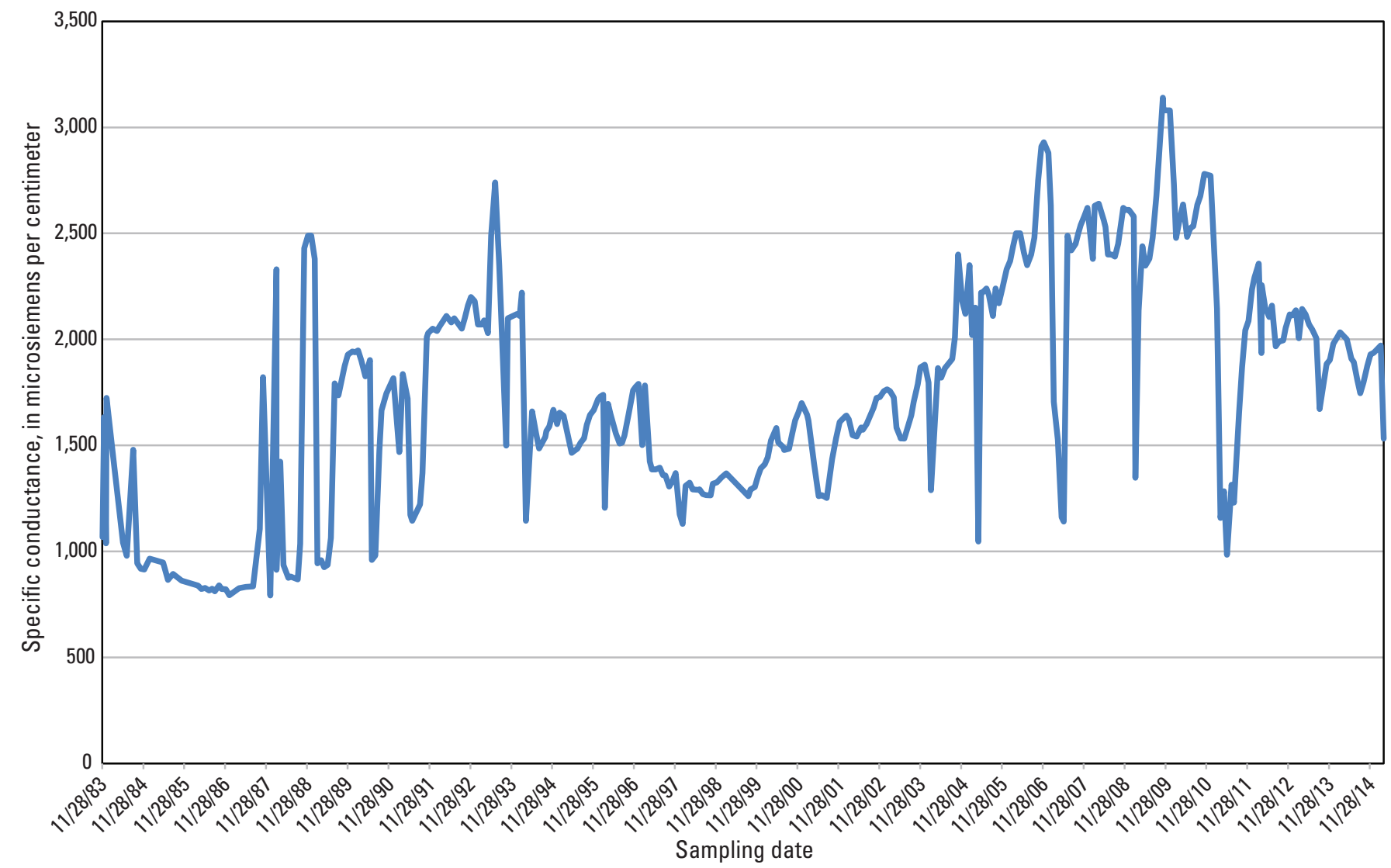

Figure 20. Historical specific conductance in Topock Marsh from November 1983 to April 2015. Samples were collected at the outlet structure in the South Dike and data were provided by Janet Kirsch, Bureau of Reclamation, Lower Colorado Region, 2015. 
Table 6. Analyses of Topock Marsh sediment samples collected in October 2011, July 2013, and October 2014.

[AB-DTPA, ammonium bicarbonate diethylene triamine penta acetic acid (analysis method); mg/L, milligram per liter; EC, electrical conductivity; mS/cm, millisiemens per centimeter; \%, percentage; OM, organic matter; $\mathrm{NO}_{3}-\mathrm{N}$, nitrate-nitrogen; $\mathrm{P}$, phosphorus; K, potassium; $\mathrm{Zn}$, zinc; $\mathrm{Fe}$, iron; Mn, manganese; $\mathrm{Cu}$, copper; TP, sampling station; Rep., replicate; ppm, parts per million; $\mathrm{S}$, sulfur; $\mathrm{B}$, boron; mg/kg,

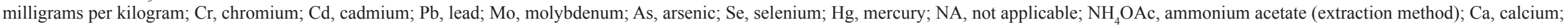
$\mathrm{Na}$, sodium]

\begin{tabular}{|c|c|c|c|c|c|c|c|c|c|c|c|c|c|}
\hline \multirow[b]{2}{*}{$\begin{array}{c}\text { Sample } \\
\text { date }\end{array}$} & \multirow[b]{2}{*}{$\begin{array}{l}\text { Sampling } \\
\text { station'1 }^{1}\end{array}$} & \multicolumn{2}{|c|}{-------Paste--------- } & \multirow[b]{2}{*}{$\begin{array}{c}\text { Lime } \\
\text { estimate }\end{array}$} & \multirow[b]{2}{*}{$\begin{array}{c}\% \\
\mathrm{OM}\end{array}$} & \multicolumn{7}{|c|}{ - } & \multirow[b]{2}{*}{$\begin{array}{l}\text { Texture } \\
\text { Estimate }\end{array}$} \\
\hline & & pH & $\begin{array}{c}\text { EC } \\
\mathrm{mS} / \mathrm{cm}\end{array}$ & & & $\mathrm{NO}_{3}-\mathrm{N}$ & $\mathbf{P}$ & $\mathbf{K}$ & $\mathrm{Zn}$ & $\mathrm{Fe}$ & Mn & ----- & \\
\hline \multirow[t]{4}{*}{ October 2011} & TP-3 & 7.8 & 1.5 & Very high & 1.5 & 1.6 & 0.5 & 154 & 2.6 & 127 & 8.2 & 4.8 & Clay \\
\hline & TP-2 & 7.6 & 2.8 & Very high & 5.1 & 1.3 & 1.6 & 288 & 6.2 & 280 & 22.5 & 12.1 & Clay \\
\hline & TP-6 & 7.8 & 3.2 & Very high & 4.9 & 2.3 & 25.2 & 390 & 4.9 & 373 & 18.5 & 10.8 & Clay \\
\hline & TP-8 & 7.7 & 3.2 & Very high & 5.8 & 0.5 & 5.5 & 263 & 2.4 & 128 & 13.0 & 6.0 & Clay \\
\hline October 2011 means & & 7.7 & 2.7 & & 4.3 & 1.4 & 8.2 & 273.8 & 4.0 & 226.8 & 15.6 & 8.4 & \\
\hline \multirow[t]{5}{*}{ July 2013} & TP-3 & 7.6 & 1.3 & Medium & 7.8 & 0.75 & 1.2 & 210.5 & 3.1 & 238.5 & 4.9 & 6.8 & Silty clay loam \\
\hline & TP-2 & 7.7 & 0.9 & Medium & 0.6 & 0.49 & 0.4 & 57.0 & 0.5 & 28.6 & 0.7 & 1.2 & Loamy sand \\
\hline & TP-6 Rep 1 & 7.6 & 1.5 & High & 1.1 & 0.28 & 0.5 & 56.4 & 0.8 & 44.0 & 7.8 & 0.7 & Loamy sand \\
\hline & TP-6 Rep 2 & 7.5 & 1.6 & High & 0.9 & 0.34 & 1.0 & 62.4 & 1.0 & 45.9 & 1.9 & 1.2 & Loamy sand \\
\hline & TP-8 & 7.7 & 2.5 & Very high & 6.6 & 0.35 & 2.5 & 538.1 & 2.7 & 256.4 & 18.1 & 9.4 & Sandy clay loam \\
\hline July 2013 means & & 7.6 & 1.6 & & 3.4 & 0.44 & 1.1 & 184.9 & 1.6 & 122.7 & 6.7 & 3.9 & \\
\hline \multirow[t]{5}{*}{ October 2014} & TP-3 & 7.9 & 0.9 & High & 2.6 & 0.39 & 2.0 & 62.3 & 0.9 & 70.3 & 2.0 & 1.3 & Sandy loam \\
\hline & TP-2 & 7.6 & 1.8 & Very high & 5.6 & 0.42 & 2.0 & 190 & 5.1 & 128.0 & 9.3 & 8.4 & Clay loam \\
\hline & TP-6 & 7.7 & 2.4 & Very high & 5.5 & 0.43 & 5.0 & 229 & 8.4 & 111.1 & 7.9 & 6.5 & Clay loam \\
\hline & TP-8 & 8.0 & 1.3 & Very high & 1.1 & 0.18 & 1.5 & 84.8 & 0.9 & 97.7 & 5.5 & 1.0 & Sandy loam \\
\hline & TP-9 & 7.9 & 1.3 & Very high & 1.6 & 0.42 & 1.5 & 104 & 1.0 & 52.8 & 3.6 & 1.2 & Clay loam \\
\hline October 2014 means & & 7.8 & 1.5 & & 3.3 & 0.37 & 2.4 & 134.0 & 3.3 & 92.0 & 5.7 & 3.7 & \\
\hline
\end{tabular}


Table 6. Analyses of Topock Marsh sediment samples collected in October 2011, July 2013, and October 2014.—Continued

[AB-DTPA, ammonium bicarbonate diethylene triamine penta acetic acid (analysis method); mg/L, milligram per liter; EC, electrical conductivity; mS/cm, millisiemens per centimeter; \%, percentage; $\mathrm{OM}$, organic matter; $\mathrm{NO}_{3}-\mathrm{N}$, nitrate-nitrogen; P, phosphorus; $\mathrm{K}$, potassium; $\mathrm{Zn}$, zinc; Fe, iron; Mn, manganese; Cu, copper; TP, sampling station; Rep., replicate; ppm, parts per million; $\mathrm{S}$, sulfur; $\mathrm{B}$, boron;

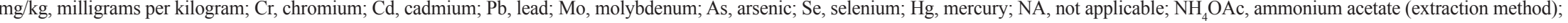
$\mathrm{Ca}$, calcium; $\mathrm{Na}$, sodium]

\begin{tabular}{|c|c|c|c|c|c|c|c|c|c|c|c|}
\hline \multirow[b]{2}{*}{$\begin{array}{c}\text { Sample } \\
\text { date }\end{array}$} & \multirow[b]{2}{*}{$\begin{array}{l}\text { Sampling } \\
\text { station }^{1}\end{array}$} & \multirow{2}{*}{$\begin{array}{l}\text { Extract- } \\
\text { able } \\
\text { ppm } \\
\text { S }\end{array}$} & \multirow{2}{*}{$\begin{array}{c}\text { Hot } \\
\text { water } \\
\text { extract B } \\
\mathrm{mg} / \mathrm{kg}\end{array}$} & \multicolumn{4}{|c|}{-----------------'Extractable------------------ } & \multicolumn{3}{|c|}{-------------'Extractable--------------- } & \\
\hline & & & & $\mathrm{Cr}$ & Cd & $\mathbf{P b}$ & $\begin{array}{l}\text { Mo } \\
--m a / k\end{array}$ & $\mathrm{As}^{2}$ & $\mathrm{Se}^{2}$ & $\mathrm{Hg}^{2}$ & \\
\hline \multirow[t]{4}{*}{ October 2011} & TP-3 & NA & NA & $<0.01$ & NA & NA & NA & 0.04 & 0.82 & $<0.005$ & \\
\hline & TP-2 & NA & NA & $<0.01$ & NA & NA & NA & 0.03 & 0.71 & $<0.005$ & \\
\hline & TP-6 & NA & NA & $<0.01$ & NA & NA & NA & 0.15 & 1.4 & $<0.005$ & \\
\hline & TP-8 & NA & NA & $<0.01$ & NA & NA & NA & 0.05 & 0.39 & $<0.005$ & \\
\hline \multirow[t]{2}{*}{ October 2011 means } & & & & $<0.01$ & & & & 0.07 & 0.83 & $<0.005$ & \\
\hline & & & & & & & & \multicolumn{3}{|c|}{----------------------Total-----------------' } & \\
\hline \multirow[t]{5}{*}{ July 2013} & TP-3 & 392 & 4.8 & 0.02 & 0.06 & 5.00 & 0.21 & 3.12 & 0.015 & 0.015 & \\
\hline & TP-2 & 111 & 3.3 & 0.01 & 0.02 & 0.77 & 0.12 & 1.01 & 0.009 & 0.009 & \\
\hline & TP-6 Rep 1 & 174 & 3.1 & 0.01 & 0.02 & 0.61 & 0.08 & 2.61 & 0.012 & 0.011 & \\
\hline & TP-6 Rep 2 & 208 & 2.9 & 0.01 & 0.02 & 0.75 & 0.06 & 2.60 & 0.010 & 0.010 & \\
\hline & TP-8 & 1,163 & 7.0 & 0.03 & 0.01 & 3.60 & 0.58 & 4.71 & 0.008 & 0.005 & \\
\hline \multirow[t]{3}{*}{ July 2013 means } & & 409.6 & 4.2 & 0.02 & 0.03 & 2.15 & 0.21 & 2.81 & 0.011 & 0.010 & \\
\hline & & & & \multicolumn{3}{|c|}{ - } & & \multicolumn{3}{|c|}{--------Total---------- } & $\%$ \\
\hline & & & & $\mathrm{Ca}$ & $\mathbf{M g}$ & $\mathrm{Na}$ & & $\mathbf{A s}^{2}$ & $\mathrm{Se}^{2}$ & $\mathrm{Hg}^{2}$ & Dry matter \\
\hline \multirow[t]{5}{*}{ October 2014} & TP-3 & 250 & 1.61 & 9.5 & 2.2 & 0.6 & & 1.90 & 0.014 & 0.013 & 57.43 \\
\hline & TP-2 & 953 & 2.19 & 18.3 & 5.7 & 1.8 & & 7.48 & 0.010 & 0.011 & 30.98 \\
\hline & TP-6 & 700 & 2.21 & 13.8 & 4.7 & 1.8 & & 2.70 & 0.015 & 0.009 & 20.22 \\
\hline & TP-8 & 162 & 1.72 & 8.8 & 2.4 & 1.0 & & 2.43 & 0.018 & 0.010 & 74.76 \\
\hline & TP-9 & 427 & 2.48 & 10.8 & 3.8 & 1.5 & & 3.03 & 0.013 & 0.014 & 46.49 \\
\hline October 2014 means & & 498.4 & 2.0 & 12.2 & 3.8 & 1.3 & & 3.51 & 0.014 & 0.011 & 45.98 \\
\hline
\end{tabular}

${ }^{1}$ Sampling stations are displayed in upstream to downstream order.

${ }^{2}$ Values were below established threshold effects of $5.9 \mathrm{mg} / \mathrm{kg}$ for As (with one exception as shown in red), $0.174 \mathrm{mg} / \mathrm{kg}$ for Hg, and $2.0 \mathrm{mg} / \mathrm{kg}$ for Se (MacDonald and others, 2000; Lemly, 2002). 
Table 7. Analyses of Topock Marsh plant samples collected in July 2013 and October 2014.

[\%, percentage; mg/kg, milligrams per kilogram; N, nitrogen; Ca, calcium; Mg, magnesium; Na, sodium; K, potassium; P, phosphorus; $\mathrm{S}$, sulfur; Fe, iron; Mn, manganese; Cu, copper; Zn, zinc; TP, sampling station; Rep, replicate; $\mathrm{B}$, boron; $\mathrm{NO}_{3}-\mathrm{N}$, nitrate-nitrogen; Mo, molybdenum; $\mathrm{Al}$, aluminum; As, arsenic; Se, selenium; Hg, mercury; $\mathrm{Cr}$, chromium]

\begin{tabular}{|c|c|c|c|c|c|c|c|c|c|c|c|c|}
\hline \multirow{2}{*}{$\begin{array}{c}\text { Sample } \\
\text { date }\end{array}$} & \multirow{2}{*}{$\begin{array}{l}\text { Sampling } \\
\text { station }^{1}\end{array}$} & \multicolumn{7}{|c|}{ 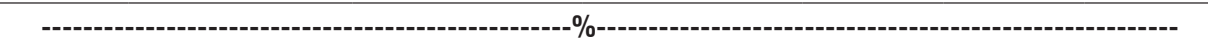 } & \multicolumn{4}{|c|}{ 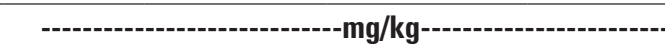 } \\
\hline & & $\mathbf{N}$ & Ca & Mg & $\mathrm{Na}$ & K & $\mathbf{P}$ & S & $\mathrm{Fe}$ & Mn & Cu & $\mathrm{Zn}$ \\
\hline \multirow[t]{5}{*}{ July 2013} & TP-3 & 0.60 & 0.16 & 0.09 & 0.38 & 0.81 & 0.45 & 0.23 & 57.3 & 431 & 0.99 & 5.11 \\
\hline & TP-2 & 0.52 & 0.19 & 0.10 & 0.30 & 0.83 & 0.55 & 0.16 & 74.1 & 106 & 1.61 & 4.90 \\
\hline & TP-6 Rep 1 & 0.46 & 0.18 & 0.07 & 0.57 & 1.16 & 0.22 & 0.26 & 44.9 & 177 & 0.66 & 4.19 \\
\hline & TP-6 Rep 2 & 0.47 & 0.11 & 0.05 & 0.28 & 0.99 & 0.13 & 0.15 & 56.0 & 96.5 & 0.42 & 2.75 \\
\hline & TP-8 & 0.50 & 0.19 & 0.12 & 1.03 & 0.81 & 0.22 & 0.56 & 50.9 & 137 & 0.31 & 1.48 \\
\hline $\begin{array}{c}\text { July } 2013 \\
\text { means }\end{array}$ & & 0.51 & 0.17 & 0.09 & 0.51 & 0.92 & 0.31 & 0.27 & 56.63 & 189.42 & 0.80 & 3.69 \\
\hline \multirow[t]{5}{*}{ October 2014} & TP-3 & 2.36 & 4.72 & 0.53 & 1.78 & 2.04 & 0.15 & 0.27 & 1,493 & 182 & 3.56 & 18.0 \\
\hline & TP-2 & 2.09 & 1.96 & 0.74 & 1.69 & 2.62 & 0.17 & 0.73 & 2,199 & 523 & 5.28 & 17.8 \\
\hline & TP-6 & 1.69 & 2.49 & 0.76 & 0.66 & 1.26 & 0.09 & 0.30 & 972 & 126 & 2.54 & 10.8 \\
\hline & TP-8 & 1.80 & 0.78 & 0.77 & 1.93 & 1.90 & 0.28 & 0.85 & 342 & 136 & 1.58 & 7.3 \\
\hline & TP-9 & 1.54 & 3.16 & 0.85 & 0.49 & 1.09 & 0.13 & 0.33 & 1,756 & 650 & 3.15 & 16.8 \\
\hline $\begin{array}{c}\text { October } 2014 \\
\text { means }\end{array}$ & & 1.90 & 2.62 & 0.73 & 1.31 & 1.78 & 0.16 & 0.50 & $1,352.40$ & 323.40 & 3.22 & 14.13 \\
\hline $\begin{array}{c}\text { Sample } \\
\text { date }\end{array}$ & $\begin{array}{l}\text { Sampling } \\
\text { station }^{1}\end{array}$ & B & $\mathrm{NO}_{3}-\mathrm{N}$ & Mo & $\begin{array}{r}\text { Al } \\
\end{array}$ & $\mathrm{As}^{2}$ & $\mathrm{Se}^{2}$ & $\mathrm{Hg}^{2}$ & $\mathrm{Cr}^{2}$ & $\begin{array}{c}\% \text { Dry } \\
\text { matter }\end{array}$ & & \\
\hline \multirow{5}{*}{$\begin{array}{l}\text { July } 2013 \\
\text { continued }\end{array}$} & TP-3 & 34.9 & 49.5 & 0.06 & 64.8 & 0.001 & 0.89 & $<0.001$ & 0.99 & 25.1 & Calif & lrush \\
\hline & TP-2 & 43.0 & 24.5 & 0.13 & 122 & 0.48 & 1.09 & $<0.001$ & 0.94 & 25.3 & Calif & Irush \\
\hline & TP-6 Rep 1 & 31.6 & 42.8 & 0.10 & 79.0 & 0.39 & 0.82 & $<0.001$ & 1.65 & 28.2 & Calif & lrush \\
\hline & TP-6 Rep 2 & 31.4 & 20.7 & $<0.01$ & 40.7 & 0.52 & 0.80 & $<0.001$ & 1.26 & 22.3 & Calif & lrush \\
\hline & TP-8 & 35.0 & 7.0 & 0.06 & 50.8 & 0.37 & 1.20 & $<0.001$ & 1.19 & 29.2 & Calif & lrush \\
\hline $\begin{array}{l}\text { July } 2013 \\
\text { means } \\
\text { continued }\end{array}$ & & 35.17 & 28.90 & 0.07 & 71.49 & 0.35 & 0.96 & $<0.001$ & 1.21 & 26.02 & & \\
\hline \multirow{5}{*}{$\begin{array}{c}\text { October } 2014 \\
\text { continued }\end{array}$} & TP-3 & 8.2 & 12.6 & 0.26 & 2,147 & 1.86 & 0.003 & $<0.001$ & NA & 8.9 & & \\
\hline & TP-2 & 1.5 & 10.6 & 0.09 & 4,968 & 1.88 & 0.001 & $<0.001$ & NA & 4.5 & Eurasi & milfoil \\
\hline & TP-6 & 15.9 & 5.9 & 0.09 & 1,481 & 0.82 & 0.004 & $<0.001$ & NA & 4.8 & & \\
\hline & TP-8 & 16.6 & 7.9 & 0.06 & 264 & 1.06 & 0.002 & $<0.001$ & NA & 4.4 & & \\
\hline & TP-9 & 22.2 & 6.9 & 0.34 & 2,994 & 2.67 & 0.004 & $<0.001$ & NA & 6.2 & & \\
\hline $\begin{array}{c}\text { October } 2014 \\
\text { means } \\
\text { continued }\end{array}$ & & 12.89 & 8.77 & 0.17 & $2,370.80$ & 1.66 & 0.003 & $<0.001$ & & 5.76 & & \\
\hline
\end{tabular}

${ }^{1}$ Sampling stations are displayed in upstream to downstream order.

${ }^{2}$ Values were below established threshold effects (MacDonald and others, 2000; Lemly, 1993, 2002).

${ }^{3}$ Plant species - California bulrush, Schoenoplectus acutus; spiny naiad, Najas marina; Eurasian watermilfoil, Myriophyllum spicatum 
Table 8. Submerged aquatic vegetation coverage ratings along east-west transects within Topock Marsh from July 2011 to October 2014.

[Data are presented in the order they were taken. Coverage ratings: $0=$ no vegetation, $1=<30 \%$ (low) vegetation coverage, $2=30 \%-<70 \%$ (moderate) coverage, and $3=70-100 \%$ (high) coverage. NAD 83: UTM - 11N, North American Datum of 1983 Universal Transverse Mercator - 11 degrees North; AdjEasting, adjusted easting units; m, meter; AdjNorthing, adjusted northing units; NTU, nephelometric turbidity unit; cm, centimeter; SAV submerged aquatic vegetation; TP, sampling station; N/A, not applicable]

\begin{tabular}{|c|c|c|c|c|c|c|c|c|c|c|c|c|c|}
\hline \multirow[b]{2}{*}{$\begin{array}{l}\text { Transect } \\
\text { name }\end{array}$} & \multirow[b]{2}{*}{ Date } & \multirow[b]{2}{*}{ Month } & \multicolumn{4}{|c|}{ NAD 83: UTM - 11N } & \multirow[b]{2}{*}{$\begin{array}{l}\text { Turbitity } \\
\text { (NTUs) }\end{array}$} & \multirow[b]{2}{*}{$\begin{array}{c}\text { Secchi } \\
\text { depth } \\
\text { (cm) }\end{array}$} & \multirow[b]{2}{*}{$\begin{array}{c}\text { SAV } \\
\text { present }\end{array}$} & \multicolumn{4}{|c|}{ Coverage } \\
\hline & & & Year & $\begin{array}{l}\text { AdjEasting } \\
\text { (m) }\end{array}$ & $\begin{array}{c}\text { AdjNorthing } \\
\text { (m) }\end{array}$ & $\begin{array}{c}\text { Water } \\
\text { depth (m) }\end{array}$ & & & & $\begin{array}{l}\text { Spiny } \\
\text { naiad }^{2}\end{array}$ & $\begin{array}{l}\text { Sago } \\
\text { pond- } \\
\text { weed }^{2}\end{array}$ & Chara $^{2}$ & $\begin{array}{c}\text { Eurasian } \\
\text { water- } \\
\text { milfoil }^{2}\end{array}$ \\
\hline TP-6 & $07 / 27 / 2011$ & July & 2011 & 726844 & 3850961 & 0.41 & 0.0 & & Yes & 2 & 0 & 0 & 0 \\
\hline TP-6 & $07 / 27 / 2011$ & July & 2011 & 726848 & 3850964 & 0.41 & 5.0 & & Yes & 2 & 0 & 0 & 0 \\
\hline TP-6 & $07 / 27 / 2011$ & July & 2011 & 726853 & 3850966 & 1.13 & 10.0 & & No & 0 & 0 & 0 & 0 \\
\hline TP-6 & $07 / 27 / 2011$ & July & 2011 & 726860 & 3850971 & 0.61 & 20.0 & & Yes & 2 & 0 & 0 & 0 \\
\hline TP-6 & $07 / 27 / 2011$ & July & 2011 & 726874 & 3850980 & 0.74 & 38.0 & & Yes & 2 & 0 & 0 & 0 \\
\hline TP-6 & $07 / 27 / 2011$ & July & 2011 & 726889 & 3850990 & 0.86 & 57.0 & & Yes & 2 & 0 & 0 & 0 \\
\hline TP-6 & $07 / 27 / 2011$ & July & 2011 & 726904 & 3850999 & 0.83 & 75.0 & & Yes & 2 & 0 & 0 & 0 \\
\hline TP-6 & $07 / 27 / 2011$ & July & 2011 & 726918 & 3851008 & 0.71 & 93.0 & & Yes & 2 & 0 & 0 & 0 \\
\hline TP-6 & $07 / 27 / 2011$ & July & 2011 & 726933 & 3851017 & 0.86 & 112.0 & & Yes & 2 & 0 & 0 & 0 \\
\hline TP-6 & $07 / 27 / 2011$ & July & 2011 & 726945 & 3851030 & 0.89 & 130.0 & & Yes & 2 & 0 & 0 & 0 \\
\hline TP-8 & $07 / 28 / 2011$ & July & 2011 & 729836 & 3847285 & 1.52 & & & No & 0 & 0 & 0 & 0 \\
\hline TP-8 & $07 / 28 / 2011$ & July & 2011 & 729837 & 3847287 & 1.58 & & & Yes & 1 & 0 & 0 & 0 \\
\hline TP-8 & $07 / 28 / 2011$ & July & 2011 & 729837 & 3847288 & 1.55 & & & No & 0 & 0 & 0 & 0 \\
\hline TP-8 & $07 / 28 / 2011$ & July & 2011 & 729839 & 3847292 & 1.46 & & & No & 0 & 0 & 0 & 0 \\
\hline TP-8 & $07 / 28 / 2011$ & July & 2011 & 729840 & 3847296 & 1.37 & & & Yes & 1 & 0 & 0 & 0 \\
\hline TP-8 & $07 / 28 / 2011$ & July & 2011 & 729842 & 3847301 & 1.31 & & & No & 0 & 0 & 0 & 0 \\
\hline TP-8 & $07 / 28 / 2011$ & July & 2011 & 729844 & 3847306 & 1.07 & & & No & 0 & 0 & 0 & 0 \\
\hline TP-8 & $07 / 28 / 2011$ & July & 2011 & 729846 & 3847310 & 0.76 & & & No & 0 & 0 & 0 & 0 \\
\hline TP-8 & $07 / 28 / 2011$ & July & 2011 & 729848 & 3847331 & 0.70 & & & No & 0 & 0 & 0 & 0 \\
\hline TP-3 & $07 / 28 / 2011$ & July & 2011 & 727395 & 3856319 & 1.01 & & & No & 0 & 0 & 0 & 0 \\
\hline TP-3 & $07 / 28 / 2011$ & July & 2011 & 727399 & 3856319 & 0.67 & & & Yes & 2 & 0 & 0 & 0 \\
\hline TP-2 & $07 / 28 / 2011$ & July & 2011 & 726434 & 3854550 & 2.59 & & & No & 0 & 0 & 0 & 0 \\
\hline TP-2 & $07 / 28 / 2011$ & July & 2011 & 726439 & 3854550 & 1.06 & & & No & 0 & 0 & 0 & 0 \\
\hline TP-5 & $07 / 28 / 2011$ & July & 2011 & 728436 & 3848187 & 0.73 & & & Yes & 1 & 0 & 0 & 0 \\
\hline TP-1 & $07 / 28 / 2011$ & July & 2011 & N/A & N/A & 1.52 & & & No & 0 & 0 & 0 & 0 \\
\hline TP-3 & $09 / 20 / 2011$ & Sept. & 2011 & 727312 & 3856305 & 0.30 & & & Yes & 3 & 1 & 0 & 0 \\
\hline TP-3 & 09/20/2011 & Sept. & 2011 & 727312 & 3856305 & 0.61 & & & Yes & 3 & 1 & 0 & 0 \\
\hline TP-3 & $09 / 20 / 2011$ & Sept. & 2011 & 727315 & 3856305 & 0.61 & & & Yes & 3 & 0 & 0 & 0 \\
\hline TP-3 & 09/20/2011 & Sept. & 2011 & 727318 & 3856305 & 0.99 & & & Yes & 1 & 0 & 0 & 0 \\
\hline TP-3 & 09/20/2011 & Sept. & 2011 & 727324 & 3856305 & 1.57 & & & No & 0 & 0 & 0 & 0 \\
\hline TP-3 & 09/20/2011 & Sept. & 2011 & 727330 & 3856305 & 2.18 & & & No & 0 & 0 & 0 & 0 \\
\hline TP-3 & 09/20/2011 & Sept. & 2011 & 727345 & 3856305 & 2.31 & & & No & 0 & 0 & 0 & 0 \\
\hline TP-3 & 09/20/2011 & Sept. & 2011 & 727373 & 3856305 & 0.74 & & & Yes & 2 & 0 & 0 & 0 \\
\hline TP-3 & 09/20/2011 & Sept. & 2011 & 727403 & 3856305 & 0.61 & & & Yes & 0 & 0 & 1 & 0 \\
\hline TP-3 & 09/20/2011 & Sept. & 2011 & 727434 & 3856307 & 0.61 & & & No & 0 & 0 & 0 & 0 \\
\hline TP-3 & 09/20/2011 & Sept. & 2011 & 727480 & 3856309 & 0.91 & & & No & 0 & 0 & 0 & 0 \\
\hline TP-3 & 09/20/2011 & Sept. & 2011 & 727522 & 3856312 & 0.66 & & & Yes & 2 & 0 & 0 & 0 \\
\hline TP-3 & 09/20/2011 & Sept. & 2011 & 727563 & 3856318 & 0.61 & & & Yes & 2 & 0 & 0 & 0 \\
\hline TP-3 & 09/20/2011 & Sept. & 2011 & 727570 & 3856321 & 0.61 & & & Yes & 3 & 0 & 0 & 0 \\
\hline TP-3 & 09/20/2011 & Sept. & 2011 & 727572 & 3856322 & 0.46 & & & Yes & 3 & 0 & 0 & 0 \\
\hline TP-3 & 09/20/2011 & Sept. & 2011 & 727576 & 3856325 & 0.30 & & & Yes & 3 & 0 & 0 & 0 \\
\hline TP-2 & 09/20/2011 & Sept. & 2011 & 726390 & 3854554 & 0.74 & & & No & 0 & 0 & 0 & 0 \\
\hline TP-2 & 09/20/2011 & Sept. & 2011 & 726391 & 3854555 & 1.27 & & & No & 0 & 0 & 0 & 0 \\
\hline TP-2 & 09/20/2011 & Sept. & 2011 & 726396 & 3854556 & 2.29 & & & No & 0 & 0 & 0 & 0 \\
\hline TP-2 & 09/20/2011 & Sept. & 2011 & 726435 & 3854557 & 1.19 & & & No & 0 & 0 & 0 & 0 \\
\hline TP-2 & 09/20/2011 & Sept. & 2011 & 726473 & 3854558 & 0.76 & & & No & 0 & 0 & 0 & 0 \\
\hline TP-2 & 09/20/2011 & Sept. & 2011 & 726526 & 3854559 & 0.61 & & & No & 0 & 0 & 0 & 0 \\
\hline TP-2 & 09/20/2011 & Sept. & 2011 & 726579 & 3854605 & 0.61 & & & No & 0 & 0 & 0 & 0 \\
\hline
\end{tabular}


Table 8. Submerged aquatic vegetation coverage ratings along east-west transects within Topock Marsh from July 2011 to 0 ctober 2014. -Continued

[Data are presented in the order they were taken. Coverage ratings: $0=$ no vegetation, $1=<30 \%$ (low) vegetation coverage, $2=30 \%-<70 \%$ (moderate) coverage, and $3=70-100 \%$ (high) coverage. NAD 83: UTM - 11N, North American Datum of 1983 Universal Transverse Mercator - 11 degrees North; AdjEasting, adjusted easting units; m, meter; AdjNorthing, adjusted northing units; NTU, nephelometric turbidity unit; cm, centimeter; SAV submerged aquatic vegetation; TP, sampling station; N/A, not applicable]

\begin{tabular}{|c|c|c|c|c|c|c|c|c|c|c|c|c|c|}
\hline \multirow[b]{2}{*}{$\begin{array}{c}\text { Transect } \\
\text { name }\end{array}$} & \multirow[b]{2}{*}{ Date } & \multirow[b]{2}{*}{ Month } & \multicolumn{4}{|c|}{ NAD 83: UTM - 11N } & \multirow[b]{2}{*}{$\begin{array}{c}\text { Turbitity } \\
\text { (NTUs) }\end{array}$} & \multirow[b]{2}{*}{$\begin{array}{c}\text { Secchi } \\
\text { depth } \\
\text { (cm) }\end{array}$} & \multirow[b]{2}{*}{$\begin{array}{c}\text { SAV } \\
\text { present }\end{array}$} & \multicolumn{4}{|c|}{ Coverage } \\
\hline & & & Year & $\begin{array}{l}\text { AdjEasting } \\
\text { (m) }\end{array}$ & $\begin{array}{l}\text { AdjNorthing } \\
\text { (m) }\end{array}$ & $\begin{array}{c}\text { Water } \\
\text { depth }(m)\end{array}$ & & & & $\begin{array}{l}\text { Spiny } \\
\text { naiad }^{2}\end{array}$ & $\begin{array}{l}\text { Sago } \\
\text { pond- } \\
\text { weed }^{2}\end{array}$ & Chara $^{2}$ & $\begin{array}{c}\text { Eurasian } \\
\text { water- } \\
\text { milfoil }^{2}\end{array}$ \\
\hline TP-2 & $09 / 20 / 2011$ & Sept. & 2011 & 726632 & 3854607 & 0.61 & & & No & 0 & 0 & 0 & 0 \\
\hline TP-2 & 09/20/2011 & Sept. & 2011 & 726685 & 3854609 & 0.51 & & & No & 0 & 0 & 0 & 0 \\
\hline TP-2 & 09/20/2011 & Sept. & 2011 & 726738 & 3854611 & 0.51 & & & No & 0 & 0 & 0 & 0 \\
\hline TP-2 & 09/20/2011 & Sept. & 2011 & 726787 & 3854615 & 0.48 & & & Yes & 0 & 2 & 0 & 0 \\
\hline TP-2 & 09/20/2011 & Sept. & 2011 & 726795 & 3854617 & & & & No & 0 & 0 & 0 & 0 \\
\hline TP-2 & 09/20/2011 & Sept. & 2011 & 726993 & 3854636 & 0.46 & & & No & 0 & 0 & 0 & 0 \\
\hline TP-2 & 09/20/2011 & Sept. & 2011 & 727043 & 3854623 & 0.46 & & & No & 0 & 0 & 0 & 0 \\
\hline TP-2 & 09/20/2011 & Sept. & 2011 & 727203 & 3854626 & 0.46 & & & No & 0 & 0 & 0 & 0 \\
\hline TP-2 & 09/20/2011 & Sept. & 2011 & 727363 & 3854629 & 0.46 & & & No & 0 & 0 & 0 & 0 \\
\hline TP-2 & 09/20/2011 & Sept. & 2011 & 727523 & 3854632 & 0.46 & & & No & 0 & 0 & 0 & 0 \\
\hline TP-2 & 09/20/2011 & Sept. & 2011 & 727691 & 3854644 & 0.37 & & & Yes & 3 & 0 & 0 & 0 \\
\hline TP-2 & 09/20/2011 & Sept. & 2011 & 727819 & 3854615 & 0.56 & & & Yes & 0 & 1 & 0 & 0 \\
\hline TP-2 & 09/20/2011 & Sept. & 2011 & 727906 & 3854615 & 0.66 & & & Yes & 0 & 1 & 0 & 0 \\
\hline TP-2 & 09/20/2011 & Sept. & 2011 & 727992 & 3854614 & 0.71 & & & No & 0 & 0 & 0 & 0 \\
\hline TP-2 & 09/20/2011 & Sept. & 2011 & 728126 & 3854613 & 0.46 & & & Yes & 0 & 1 & 0 & 0 \\
\hline TP-1 & 09/20/2011 & Sept. & 2011 & 728059 & 3853217 & 0.30 & & & No & 0 & 0 & 0 & 0 \\
\hline TP-1 & 09/20/2011 & Sept. & 2011 & 728058 & 3853216 & 0.46 & & & No & 0 & 0 & 0 & 0 \\
\hline TP-1 & 09/20/2011 & Sept. & 2011 & 727998 & 3853156 & 1.07 & & & No & 0 & 0 & 0 & 0 \\
\hline TP-1 & 09/20/2011 & Sept. & 2011 & 727937 & 3853095 & 0.99 & & & No & 0 & 0 & 0 & 0 \\
\hline TP-1 & 09/20/2011 & Sept. & 2011 & 727876 & 3853034 & 0.30 & & & Yes & 1 & 1 & 0 & 0 \\
\hline TP-1 & 09/20/2011 & Sept. & 2011 & 727725 & 3852980 & 0.61 & & & No & 0 & 0 & 0 & 0 \\
\hline TP-1 & 09/20/2011 & Sept. & 2011 & 727815 & 3852975 & 0.61 & & & Yes & 1 & 1 & 0 & 0 \\
\hline TP-1 & 09/20/2011 & Sept. & 2011 & 727754 & 3852971 & 0.79 & & & No & 0 & 0 & 0 & 0 \\
\hline TP-1 & 09/20/2011 & Sept. & 2011 & 727693 & 3852968 & 0.76 & & & No & 0 & 0 & 0 & 0 \\
\hline TP-1 & 09/20/2011 & Sept. & 2011 & 727632 & 3852965 & 0.48 & & & Yes & 1 & 1 & 0 & 0 \\
\hline TP-1 & 09/20/2011 & Sept. & 2011 & 727586 & 3852963 & 0.46 & & & Yes & 1 & 1 & 0 & 0 \\
\hline TP-1 & 09/20/2011 & Sept. & 2011 & 727267 & 3852931 & 0.48 & & & Yes & 0 & 2 & 0 & 0 \\
\hline TP-1 & 09/20/2011 & Sept. & 2011 & 726550 & 3853569 & 0.48 & & & Yes & 0 & 1 & 0 & 0 \\
\hline TP-1 & 09/20/2011 & Sept. & 2011 & 726106 & 3853617 & 0.71 & & & No & 0 & 0 & 0 & 0 \\
\hline TP-1 & 09/20/2011 & Sept. & 2011 & 726012 & 3853617 & 1.32 & & & No & 0 & 0 & 0 & 0 \\
\hline TP-1 & 09/20/2011 & Sept. & 2011 & & & 0.94 & & & No & 0 & 0 & 0 & 0 \\
\hline TP-1 & 09/20/2011 & Sept. & 2011 & 726020 & 3853592 & 0 & & & No & 0 & 0 & 0 & 0 \\
\hline TP-6 & 09/22/2011 & Sept. & 2011 & 726794 & 3850995 & 0.27 & & & Yes & 3 & 1 & 0 & 0 \\
\hline TP-6 & 09/22/2011 & Sept. & 2011 & 726800 & 3851005 & 0.37 & & & Yes & 3 & 1 & 0 & 0 \\
\hline TP-6 & $09 / 22 / 2011$ & Sept. & 2011 & 726806 & 3851005 & 0.55 & & & Yes & 3 & 0 & 0 & 0 \\
\hline TP-6 & 09/22/2011 & Sept. & 2011 & 726845 & 3851005 & 0.61 & & & Yes & 3 & 0 & 0 & 0 \\
\hline TP-6 & 09/22/2011 & Sept. & 2011 & 726906 & 3851007 & 0.61 & & & Yes & 3 & 0 & 0 & 0 \\
\hline TP-6 & 09/22/2011 & Sept. & 2011 & 726936 & 3851009 & 0.61 & & & Yes & 3 & 0 & 0 & 0 \\
\hline TP-6 & 09/22/2011 & Sept. & 2011 & 726951 & 3851011 & 0.61 & & & Yes & 3 & 0 & 0 & 0 \\
\hline TP-6 & 09/22/2011 & Sept. & 2011 & 726966 & 3851013 & 0.73 & & & Yes & 3 & 0 & 0 & 0 \\
\hline TP-6 & 09/22/2011 & Sept. & 2011 & 726997 & 3851015 & 0.71 & & & Yes & 2 & 1 & 0 & 0 \\
\hline TP-6 & 09/22/2011 & Sept. & 2011 & 727149 & 3851017 & 0.71 & & & Yes & 1 & 1 & 0 & 0 \\
\hline TP-6 & $09 / 22 / 2011$ & Sept. & 2011 & 727302 & 3851019 & 0.86 & & & Yes & 1 & 0 & 0 & 0 \\
\hline TP-6 & $09 / 22 / 2011$ & Sept. & 2011 & 727607 & 3851021 & 1.09 & & & Yes & 0 & 1 & 0 & 0 \\
\hline TP-6 & 09/22/2011 & Sept. & 2011 & 727759 & 3851023 & 0.94 & & & Yes & 1 & 0 & 0 & 0 \\
\hline TP-6 & 09/22/2011 & Sept. & 2011 & 727881 & 3851024 & 1.35 & & & No & 0 & 0 & 0 & 0 \\
\hline TP-6 & 09/22/2011 & Sept. & 2011 & 728003 & 3851025 & 1.02 & & & Yes & 1 & 0 & 0 & 0 \\
\hline TP-6 & 09/22/2011 & Sept. & 2011 & 728125 & 3851027 & 0.86 & & & Yes & 2 & 0 & 0 & 0 \\
\hline
\end{tabular}


Table 8. Submerged aquatic vegetation coverage ratings along east-west transects within Topock Marsh from July 2011 to 0 ctober 2014. -Continued

[Data are presented in the order they were taken. Coverage ratings: $0=$ no vegetation, $1=<30 \%$ (low) vegetation coverage, $2=30 \%-<70 \%$ (moderate) coverage, and $3=70-100 \%$ (high) coverage. NAD 83: UTM - 11N, North American Datum of 1983 Universal Transverse Mercator - 11 degrees North; AdjEasting, adjusted easting units; m, meter; AdjNorthing, adjusted northing units; NTU, nephelometric turbidity unit; cm, centimeter; SAV submerged aquatic vegetation; TP, sampling station; N/A, not applicable]

\begin{tabular}{|c|c|c|c|c|c|c|c|c|c|c|c|c|c|}
\hline \multirow[b]{2}{*}{$\begin{array}{l}\text { Transect } \\
\text { name }\end{array}$} & \multirow[b]{2}{*}{ Date } & \multirow[b]{2}{*}{ Month } & \multirow[b]{2}{*}{ Year } & \multicolumn{2}{|c|}{ NAD 83: UTM - 11N } & \multirow[b]{2}{*}{$\begin{array}{c}\text { Water } \\
\text { depth }(m)\end{array}$} & \multirow[b]{2}{*}{$\begin{array}{c}\text { Turbitity } \\
\text { (NTUs) }\end{array}$} & \multirow[b]{2}{*}{$\begin{array}{c}\text { Secchi } \\
\text { depth } \\
\text { (cm) }\end{array}$} & \multirow[b]{2}{*}{$\begin{array}{c}\text { SAV } \\
\text { present }\end{array}$} & \multicolumn{4}{|c|}{ Coverage } \\
\hline & & & & $\begin{array}{l}\text { AdjEasting } \\
\text { (m) }\end{array}$ & $\begin{array}{l}\text { AdjNorthing } \\
\text { (m) }\end{array}$ & & & & & $\begin{array}{c}\text { Spiny } \\
\text { naiad }^{2}\end{array}$ & $\begin{array}{l}\text { Sago } \\
\text { pond- } \\
\text { weed }^{2}\end{array}$ & Chara $^{2}$ & $\begin{array}{c}\text { Eurasian } \\
\text { water- } \\
\text { milfoil }^{2}\end{array}$ \\
\hline TP-6 & $09 / 22 / 2011$ & Sept. & 2011 & 728210 & 3851030 & 0.79 & & & Yes & 1 & 0 & 0 & 0 \\
\hline TP-6 & $09 / 22 / 2011$ & Sept. & 2011 & 728260 & 3851030 & 1.40 & & & No & 0 & 0 & 0 & 0 \\
\hline TP-6 & $09 / 22 / 2011$ & Sept. & 2011 & 728443 & 3851030 & 1.22 & & & No & 0 & 0 & 0 & 0 \\
\hline TP-6 & $09 / 22 / 2011$ & Sept. & 2011 & 728449 & 3851030 & 0.91 & & & No & 0 & 0 & 0 & 0 \\
\hline TP-6 & $09 / 22 / 2011$ & Sept. & 2011 & 728455 & 3851030 & 0.64 & & & No & 0 & 0 & 0 & 0 \\
\hline TP-6 & $09 / 22 / 2011$ & Sept. & 2011 & 728458 & 3851021 & 0 & & & No & 0 & 0 & 0 & 0 \\
\hline Between & & & & & & & & & & & & & \\
\hline $\begin{array}{l}\text { TP-6 and } \\
\text { TP-5 }\end{array}$ & $09 / 22 / 2011$ & Sept. & 2011 & N/A & N/A & 1.07 & & & Yes & 2.5 & 0 & 0 & 0 \\
\hline Between & & & & & & & & & & & & & \\
\hline $\begin{array}{l}\text { TP-6 and } \\
\text { TP-5 }\end{array}$ & $09 / 22 / 2011$ & Sept. & 2011 & N/A & N/A & 0.30 & & & Yes & 2.5 & 1 & 0 & 0 \\
\hline TP-5 & $09 / 22 / 2011$ & Sept. & 2011 & 728436 & 3848187 & 0.56 & & & Yes & 3 & 2 & 0 & 0 \\
\hline TP-5 & $09 / 22 / 2011$ & Sept. & 2011 & 728438 & 3848187 & 0.69 & & & Yes & 3 & 2 & 0 & 0 \\
\hline TP-5 & $09 / 22 / 2011$ & Sept. & 2011 & 728442 & 3848187 & 0.74 & & & Yes & 2 & 3 & 0 & 0 \\
\hline TP-5 & $09 / 22 / 2011$ & Sept. & 2011 & 728443 & 3848187 & 0.76 & & & Yes & 2 & 3 & 0 & 0 \\
\hline TP-5 & $09 / 22 / 2011$ & Sept. & 2011 & 728451 & 3848187 & 1.07 & & & Yes & 3 & 0 & 0 & 0 \\
\hline TP-5 & $09 / 22 / 2011$ & Sept. & 2011 & 728466 & 3848187 & 1.57 & & & Yes & 2 & 0 & 0 & 0 \\
\hline TP-5 & $09 / 22 / 2011$ & Sept. & 2011 & 728557 & 3848227 & 1.57 & & & Yes & 2 & 0 & 0 & 0 \\
\hline TP-5 & $09 / 22 / 2011$ & Sept. & 2011 & 728664 & 3848274 & 1.83 & & & Yes & 1.5 & 0 & 0 & 0 \\
\hline TP-5 & $09 / 22 / 2011$ & Sept. & 2011 & 728760 & 3848294 & 1.83 & & & Yes & 2 & 0 & 0 & 0 \\
\hline TP-5 & $09 / 22 / 2011$ & Sept. & 2011 & 728863 & 3848314 & 1.68 & & & Yes & 1 & 0 & 0 & 0 \\
\hline TP-5 & $09 / 22 / 2011$ & Sept. & 2011 & 728976 & 3848320 & 1.83 & & & No & 0 & 0 & 0 & 0 \\
\hline TP-5 & $09 / 22 / 2011$ & Sept. & 2011 & 729089 & 3848326 & 1.91 & & & No & 0 & 0 & 0 & 0 \\
\hline TP-5 & $09 / 22 / 2011$ & Sept. & 2011 & 729172 & 3848334 & 1.96 & & & Yes & 1 & 0 & 0 & 0 \\
\hline TP-5 & $09 / 22 / 2011$ & Sept. & 2011 & 729275 & 3848342 & 1.52 & & & Yes & 1 & 0 & 0 & 0 \\
\hline TP-5 & $09 / 22 / 2011$ & Sept. & 2011 & 729378 & 3848350 & 1.12 & & & Yes & 3 & 1 & 0 & 0 \\
\hline TP-5 & $09 / 22 / 2011$ & Sept. & 2011 & 729392 & 3848358 & 0.61 & & & Yes & 3 & 0 & 0 & 0 \\
\hline TP-5 & $09 / 22 / 2011$ & Sept. & 2011 & 729400 & 3848366 & 0.56 & & & Yes & 3 & 0 & 0 & 0 \\
\hline TP-5 & $09 / 22 / 2011$ & Sept. & 2011 & 729403 & 3848374 & 0.25 & & & Yes & 3 & 0 & 0 & 0 \\
\hline TP-5 & $09 / 22 / 2011$ & Sept. & 2011 & 729405 & 3848382 & 0.15 & & & Yes & 3 & 0 & 0 & 0 \\
\hline TP-5 & $09 / 22 / 2011$ & Sept. & 2011 & 729443 & 3848389 & 0.08 & & & Yes & 2 & 1 & 0 & 0 \\
\hline TP-8 & $09 / 22 / 2011$ & Sept. & 2011 & 730114 & 3847310 & 0.30 & & & Yes & 1 & 3 & 0 & 0 \\
\hline TP-8 & $09 / 22 / 2011$ & Sept. & 2011 & 730113 & 3847310 & 0.36 & & & Yes & 1 & 3 & 0 & 0 \\
\hline TP-8 & $09 / 22 / 2011$ & Sept. & 2011 & 730111 & 3847310 & 0.36 & & & Yes & 1 & 3 & 0 & 0 \\
\hline TP- 8 & $09 / 22 / 2011$ & Sept. & 2011 & 730108 & 3847307 & 0.36 & & & Yes & 1 & 3 & 0 & 0 \\
\hline TP-8 & $09 / 22 / 2011$ & Sept. & 2011 & 730102 & 3847307 & 0.71 & & & Yes & 3 & 1 & 0 & 0 \\
\hline TP-8 & $09 / 22 / 2011$ & Sept. & 2011 & 730096 & 3847307 & 1.12 & & & Yes & 3 & 0 & 0 & 0 \\
\hline TP-8 & $09 / 22 / 2011$ & Sept. & 2011 & 730084 & 3847305 & 1.22 & & & Yes & 2 & 0 & 0 & 0 \\
\hline TP-8 & $09 / 22 / 2011$ & Sept. & 2011 & 730068 & 3847305 & 1.37 & & & Yes & 1 & 0 & 0 & 0 \\
\hline TP-8 & $09 / 22 / 2011$ & Sept. & 2011 & 730053 & 3847305 & 1.37 & & & Yes & 1 & 0 & 0 & 0 \\
\hline TP-8 & $09 / 22 / 2011$ & Sept. & 2011 & 729953 & 3847295 & 1.37 & & & Yes & 1 & 0 & 0 & 0 \\
\hline TP-8 & $09 / 22 / 2011$ & Sept. & 2011 & 729836 & 3847285 & 1.78 & & & Yes & 1 & 0 & 0 & 0 \\
\hline TP-8 & $09 / 22 / 2011$ & Sept. & 2011 & 729753 & 3847275 & 1.52 & & & Yes & 1 & 0 & 0 & 0 \\
\hline TP-8 & $09 / 22 / 2011$ & Sept. & 2011 & 729653 & 3847265 & 1.65 & & & Yes & 1 & 0 & 0 & 0 \\
\hline TP-8 & $09 / 22 / 2011$ & Sept. & 2011 & 729552 & 3847255 & 1.19 & & & Yes & 2 & 0 & 0 & 0 \\
\hline TP-8 & $09 / 22 / 2011$ & Sept. & 2011 & 729452 & 3847250 & 1.65 & & & No & 0 & 0 & 0 & 0 \\
\hline TP-8 & $09 / 22 / 2011$ & Sept. & 2011 & 729352 & 3847250 & 1.52 & & & No & 0 & 0 & 0 & 0 \\
\hline
\end{tabular}


Table 8. Submerged aquatic vegetation coverage ratings along east-west transects within Topock Marsh from July 2011 to 0 ctober 2014. -Continued

[Data are presented in the order they were taken. Coverage ratings: $0=$ no vegetation, $1=<30 \%$ (low) vegetation coverage, $2=30 \%-<70 \%$ (moderate) coverage, and $3=70-100 \%$ (high) coverage. NAD 83: UTM - 11N, North American Datum of 1983 Universal Transverse Mercator - 11 degrees North; AdjEasting, adjusted easting units; m, meter; AdjNorthing, adjusted northing units; NTU, nephelometric turbidity unit; $\mathrm{cm}$, centimeter; SAV submerged aquatic vegetation; TP, sampling station; N/A, not applicable]

\begin{tabular}{|c|c|c|c|c|c|c|c|c|c|c|c|c|c|}
\hline \multirow[b]{2}{*}{$\begin{array}{l}\text { Transect } \\
\text { name }\end{array}$} & \multirow[b]{2}{*}{ Date } & \multirow[b]{2}{*}{ Month } & \multicolumn{4}{|c|}{ NAD 83: UTM - 11N } & \multirow[b]{2}{*}{$\begin{array}{c}\text { Turbitity } \\
\text { (NTUs) }\end{array}$} & \multirow[b]{2}{*}{$\begin{array}{c}\text { Secchi } \\
\text { depth } \\
\text { (cm) }\end{array}$} & \multirow[b]{2}{*}{$\begin{array}{c}\text { SAV } \\
\text { present }\end{array}$} & \multicolumn{4}{|c|}{ Coverage } \\
\hline & & & Year & $\begin{array}{l}\text { AdjEasting } \\
\text { (m) }\end{array}$ & $\begin{array}{l}\text { AdjNorthing } \\
\text { (m) }\end{array}$ & $\begin{array}{c}\text { Water } \\
\text { depth }(m)\end{array}$ & & & & $\begin{array}{l}\text { Spiny } \\
\text { naiad }^{2}\end{array}$ & $\begin{array}{l}\text { Sago } \\
\text { pond- } \\
\text { weed }^{2}\end{array}$ & Chara $^{2}$ & $\begin{array}{c}\text { Eurasian } \\
\text { water- } \\
\text { milfoil }^{2}\end{array}$ \\
\hline TP-8 & $09 / 22 / 2011$ & Sept. & 2011 & 729337 & 3847245 & 1.30 & & & Yes & 3 & 0 & 0 & 0 \\
\hline TP-8 & $09 / 22 / 2011$ & Sept. & 2011 & 729343 & 3847235 & 1.22 & & & Yes & 3 & 0 & 0 & 0 \\
\hline TP-8 & $09 / 22 / 2011$ & Sept. & 2011 & 729331 & 3847225 & 0.79 & & & Yes & 3 & 1 & 0 & 0 \\
\hline TP-8 & $09 / 22 / 2011$ & Sept. & 2011 & 729325 & 3847215 & 0.30 & & & Yes & 3 & 3 & 0 & 0 \\
\hline ТP-8 & $09 / 22 / 2011$ & Sept. & 2011 & 729323 & 3847205 & 0.30 & & & Yes & 3 & 3 & 0 & 0 \\
\hline TP-8 & $09 / 22 / 2011$ & Sept. & 2011 & 729323 & 3847189 & 0.30 & & & Yes & 3 & 3 & 0 & 0 \\
\hline $\begin{array}{l}\text { Topock } \\
6-1 \text { thru } \\
\text { channels }\end{array}$ & $09 / 22 / 2011$ & Sept. & 2011 & N/A & N/A & $\leq 0.91$ & & & Yes & 2.5 & 0 & 0 & 0 \\
\hline TP-0 & $10 / 24 / 2011$ & Oct.. & 2011 & 726688 & 3857706 & 0.30 & & & Yes & 2 & 0 & 0 & 0 \\
\hline TP-0 & $10 / 24 / 2011$ & Oct. & 2011 & 726690 & 3857707 & 0.91 & & & Yes & 2 & 0 & 0 & 0 \\
\hline TP-0 & $10 / 24 / 2011$ & Oct. & 2011 & 726691 & 3857707 & 1.22 & & & Yes & 2 & 0 & 0 & 0 \\
\hline TP-0 & $10 / 24 / 2011$ & Oct. & 2011 & 726693 & 3857708 & 1.52 & & & Yes & 2 & 0 & 0 & 0 \\
\hline TP-0 & $10 / 24 / 2011$ & Oct. & 2011 & 726699 & 3857708 & 2.59 & & & Yes & 2 & 0 & 0 & 0 \\
\hline TP-0 & $10 / 24 / 2011$ & Oct. & 2011 & 726708 & 3857709 & 0.72 & & & Yes & 3 & 0 & 0 & 0 \\
\hline TP-0 & $10 / 24 / 2011$ & Oct. & 2011 & 726719 & 3857710 & 2.13 & & & Yes & 2 & 0 & 0 & 0 \\
\hline TP-0 & $10 / 24 / 2011$ & Oct. & 2011 & 726750 & 3857709 & 2.07 & & & Yes & 1 & 0 & 0 & 0 \\
\hline TP-0 & $10 / 24 / 2011$ & Oct. & 2011 & 726780 & 3857713 & 3.14 & & & Yes & 1 & 0 & 0 & 0 \\
\hline TP-0 & $10 / 24 / 2011$ & Oct. & 2011 & 726811 & 3857717 & 0.70 & & & Yes & 2 & 0 & 0 & 0 \\
\hline TP-0 & $10 / 24 / 2011$ & Oct. & 2011 & 726848 & 3857730 & 1.25 & & & Yes & 2 & 0 & 0 & 0 \\
\hline TP-0 & $10 / 24 / 2011$ & Oct. & 2011 & 726896 & 3857755 & 0.46 & & & Yes & 2 & 0 & 0 & 0 \\
\hline TP-0 & $10 / 24 / 2011$ & Oct. & 2011 & 726921 & 3857770 & 0.30 & & & Yes & 2 & 2 & 0 & 0 \\
\hline TP-1 & $10 / 24 / 2011$ & Oct. & 2011 & 726020 & 3853594 & 0.73 & & & No & 0 & 0 & 0 & 0 \\
\hline TP-1 & $10 / 24 / 2011$ & Oct. & 2011 & 726022 & 3853594 & 0.82 & & & No & 0 & 0 & 0 & 0 \\
\hline TP-1 & $10 / 24 / 2011$ & Oct. & 2011 & 726023 & 3853594 & 0.91 & & & No & 0 & 0 & 0 & 0 \\
\hline TP-1 & $10 / 24 / 2011$ & Oct. & 2011 & 726032 & 3853590 & 1.95 & & & No & 0 & 0 & 0 & 0 \\
\hline TP-1 & $10 / 24 / 2011$ & Oct. & 2011 & 726044 & 3853586 & 0.76 & & & No & 0 & 0 & 0 & 0 \\
\hline TP-1 & $10 / 24 / 2011$ & Oct. & 2011 & 726066 & 3853582 & 0.58 & & & No & 0 & 0 & 0 & 0 \\
\hline TP-1 & $10 / 24 / 2011$ & Oct. & 2011 & 726096 & 3853578 & 0.61 & & & No & 0 & 0 & 0 & 0 \\
\hline TP-1 & $10 / 24 / 2011$ & Oct. & 2011 & & & 0.64 & & & Yes & 1 & 0 & 0 & 0 \\
\hline TP-1 & $10 / 24 / 2011$ & Oct. & 2011 & 726331 & 3853570 & 0.64 & & & No & 0 & 0 & 0 & 0 \\
\hline TP-1 & $10 / 24 / 2011$ & Oct. & 2011 & 726449 & 3853566 & 0.70 & & & No & 0 & 0 & 0 & 0 \\
\hline TP-1 & $10 / 24 / 2011$ & Oct. & 2011 & 726566 & 3853562 & 0.61 & & & No & 0 & 0 & 0 & 0 \\
\hline TP-1 & $10 / 24 / 2011$ & Oct. & 2011 & 726683 & 3853558 & 0.58 & & & Yes & 2 & 0 & 0 & 0 \\
\hline TP-1 & $10 / 24 / 2011$ & Oct. & 2011 & 726801 & 3853554 & 0.40 & & & Yes & 2 & 0 & 0 & 0 \\
\hline TP-1 & $10 / 24 / 2011$ & Oct. & 2011 & 726918 & 3853550 & 0.40 & & & Yes & 1 & 0 & 0 & 0 \\
\hline TP-1 & $10 / 24 / 2011$ & Oct. & 2011 & 727036 & 3853521 & 0.49 & & & Yes & 0 & 1 & 0 & 0 \\
\hline TP-1 & $10 / 24 / 2011$ & Oct. & 2011 & 727153 & 3853492 & 0.61 & & & Yes & 0 & 1 & 0 & 0 \\
\hline TP-1 & $10 / 24 / 2011$ & Oct. & 2011 & 727271 & 3853463 & 0.79 & & & No & 0 & 0 & 0 & 0 \\
\hline TP-1 & $10 / 24 / 2011$ & Oct. & 2011 & 727388 & 3853434 & 0.91 & & & No & 0 & 0 & 0 & 0 \\
\hline TP-1 & $10 / 24 / 2011$ & Oct. & 2011 & 727506 & 3853405 & 0.88 & & & No & 0 & 0 & 0 & 0 \\
\hline TP-1 & $10 / 24 / 2011$ & Oct. & 2011 & 727623 & 3853376 & 0.91 & & & No & 0 & 0 & 0 & 0 \\
\hline TP-1 & $10 / 24 / 2011$ & Oct. & 2011 & 727740 & 3853347 & 1.10 & & & No & 0 & 0 & 0 & 0 \\
\hline TP-1 & $10 / 24 / 2011$ & Oct. & 2011 & 727858 & 3853318 & 1.13 & & & No & 0 & 0 & 0 & 0 \\
\hline TP-1 & $10 / 24 / 2011$ & Oct. & 2011 & 727975 & 3853289 & 0.98 & & & No & 0 & 0 & 0 & 0 \\
\hline TP-1 & $10 / 24 / 2011$ & Oct. & 2011 & 728093 & 3853260 & 0.94 & & & No & 0 & 0 & 0 & 0 \\
\hline TP-1 & $10 / 24 / 2011$ & Oct. & 2011 & 728105 & 3853257 & 0.91 & & & Yes & 1 & 0 & 0 & 0 \\
\hline
\end{tabular}


Table 8. Submerged aquatic vegetation coverage ratings along east-west transects within Topock Marsh from July 2011 to 0 ctober 2014. -Continued

[Data are presented in the order they were taken. Coverage ratings: $0=$ no vegetation, $1=<30 \%$ (low) vegetation coverage, $2=30 \%-<70 \%$ (moderate) coverage, and $3=70-100 \%$ (high) coverage. NAD 83: UTM - 11N, North American Datum of 1983 Universal Transverse Mercator - 11 degrees North; AdjEasting, adjusted easting units; m, meter; AdjNorthing, adjusted northing units; NTU, nephelometric turbidity unit; cm, centimeter; SAV submerged aquatic vegetation; TP, sampling station; N/A, not applicable]

\begin{tabular}{|c|c|c|c|c|c|c|c|c|c|c|c|c|c|}
\hline \multirow[b]{2}{*}{$\begin{array}{l}\text { Transect } \\
\text { name }\end{array}$} & \multirow[b]{2}{*}{ Date } & \multirow[b]{2}{*}{ Month } & \multirow[b]{2}{*}{ Year } & \multicolumn{2}{|c|}{ NAD 83: UTM - 11N } & \multirow[b]{2}{*}{$\begin{array}{c}\text { Water } \\
\text { depth }(m)\end{array}$} & \multirow[b]{2}{*}{$\begin{array}{c}\text { Turbitity } \\
\text { (NTUs) }\end{array}$} & \multirow[b]{2}{*}{$\begin{array}{c}\text { Secchi } \\
\text { depth } \\
\text { (cm) }\end{array}$} & \multirow[b]{2}{*}{$\begin{array}{c}\text { SAV } \\
\text { present }\end{array}$} & \multicolumn{4}{|c|}{ Coverage } \\
\hline & & & & $\begin{array}{l}\text { AdjEasting } \\
\text { (m) }\end{array}$ & $\begin{array}{l}\text { AdjNorthing } \\
\text { (m) }\end{array}$ & & & & & $\begin{array}{l}\text { Spiny } \\
\text { naiad }^{2}\end{array}$ & $\begin{array}{l}\text { Sago } \\
\text { pond- } \\
\text { weed }^{2}\end{array}$ & Chara $^{2}$ & $\begin{array}{c}\text { Eurasian } \\
\text { water- } \\
\text { milfoil }^{2}\end{array}$ \\
\hline TP-1 & $10 / 24 / 2011$ & Oct. & 2011 & 728119 & 3853254 & 0.58 & & & No & 0 & 0 & 0 & 0 \\
\hline TP-1 & $10 / 24 / 2011$ & Oct. & 2011 & 728120 & 3853254 & 0.46 & & & Yes & 1 & 0 & 0 & 0 \\
\hline TP-1 & $10 / 24 / 2011$ & Oct. & 2011 & 728122 & 3853253 & 0.46 & & & No & 0 & 0 & 0 & 0 \\
\hline TP-1 & $10 / 24 / 2011$ & Oct. & 2011 & 728066 & 3853253 & 0 & & & No & 0 & 0 & 0 & 0 \\
\hline ТP-9 & $10 / 24 / 2011$ & Oct. & 2011 & 730380 & 3846849 & 0.06 & & & Yes & 0 & 0 & 1 & 0 \\
\hline ТP-9 & $10 / 24 / 2011$ & Oct. & 2011 & 730378 & 3846849 & 0.30 & & & Yes & 0 & 2 & 0 & 0 \\
\hline ТР-9 & $10 / 24 / 2011$ & Oct. & 2011 & 730377 & 3846849 & 0.46 & & & Yes & 2 & 1 & 0 & 0 \\
\hline TP-9 & $10 / 24 / 2011$ & Oct. & 2011 & 730375 & 3846849 & 0.61 & & & Yes & 3 & 0 & 0 & 0 \\
\hline ТР-9 & $10 / 24 / 2011$ & Oct. & 2011 & 730368 & 3846849 & 0.61 & & & Yes & 3 & 0 & 0 & 0 \\
\hline ТP-9 & $10 / 24 / 2011$ & Oct. & 2011 & 730362 & 3846849 & 0.84 & & & Yes & 2 & 0 & 0 & 0 \\
\hline TP-9 & $10 / 24 / 2011$ & Oct. & 2011 & 730298 & 3846815 & 0.76 & & & Yes & 2 & 0 & 0 & 0 \\
\hline TP-9 & $10 / 24 / 2011$ & Oct. & 2011 & 730234 & 3846815 & 0.46 & & & Yes & 3 & 1 & 0 & 0 \\
\hline TP-9 & $10 / 24 / 2011$ & Oct. & 2011 & 730171 & 3846815 & 0.61 & & & Yes & 3 & 0 & 0 & 0 \\
\hline TP-9 & $10 / 24 / 2011$ & Oct. & 2011 & 730107 & 3846815 & 0.86 & & & Yes & 2 & 0 & 0 & 0 \\
\hline TP-9 & $10 / 24 / 2011$ & Oct. & 2011 & 730043 & 3846815 & 0.30 & & & Yes & 0 & 2 & 0 & 0 \\
\hline ТP-9 & $10 / 24 / 2011$ & Oct. & 2011 & 729979 & 3846815 & 0.61 & & & Yes & 2 & 0 & 0 & 0 \\
\hline TP-9 & $10 / 24 / 2011$ & Oct. & 2011 & 729915 & 3846815 & 0.76 & & & Yes & 3 & 0 & 0 & 0 \\
\hline ТР-9 & $10 / 24 / 2011$ & Oct. & 2011 & 729852 & 3846815 & 0.86 & & & Yes & 2 & 0 & 0 & 0 \\
\hline ТР-9 & $10 / 24 / 2011$ & Oct. & 2011 & 729788 & 3846815 & 0.91 & & & Yes & 2 & 0 & 0 & 0 \\
\hline ТР-9 & $10 / 24 / 2011$ & Oct. & 2011 & 729786 & 3846788 & & & & No & 0 & 0 & 0 & 0 \\
\hline ТP-9 & $10 / 24 / 2011$ & Oct. & 2011 & 729700 & 3846815 & 0.86 & & & No & 0 & 0 & 0 & 0 \\
\hline TP-9 & $10 / 24 / 2011$ & Oct. & 2011 & 729655 & 3846815 & 0.30 & & & Yes & 0 & 2 & 0 & 0 \\
\hline ТР-9 & $10 / 24 / 2011$ & Oct. & 2011 & 729652 & 3846815 & 0.61 & & & No & 0 & 0 & 0 & 0 \\
\hline ТP-9 & $10 / 24 / 2011$ & Oct. & 2011 & 729650 & 3846815 & 0.23 & & & Yes & 0 & 2 & 0 & 0 \\
\hline TP-9 & $10 / 24 / 2011$ & Oct. & 2011 & 729646 & 3846815 & 0.15 & & & Yes & 0 & 1 & 0 & 0 \\
\hline TP-3 & $01 / 31 / 2012$ & Jan. & 2012 & 727328 & 3856241 & 0.3 & & & No & 0 & 0 & 0 & 0 \\
\hline TP-3 & $01 / 31 / 2012$ & Jan. & 2012 & 727331 & 3856241 & 0.9 & & & No & 0 & 0 & 0 & 0 \\
\hline TP-3 & $01 / 31 / 2012$ & Jan. & 2012 & 727336 & 3856240 & 1.7 & & & No & 0 & 0 & 0 & 0 \\
\hline TP-3 & $01 / 31 / 2012$ & Jan. & 2012 & 727343 & 3856240 & 1.8 & & & No & 0 & 0 & 0 & 0 \\
\hline TP-3 & $01 / 31 / 2012$ & Jan. & 2012 & 727374 & 3856239 & 0.5 & & & No & 0 & 0 & 0 & 0 \\
\hline TP-3 & $01 / 31 / 2012$ & Jan. & 2012 & 727404 & 3856239 & & 105.0 & & No & 0 & 0 & 0 & 0 \\
\hline TP-3 & $01 / 31 / 2012$ & Jan. & 2012 & 727435 & 3856238 & & 40.3 & & No & 0 & 0 & 0 & 0 \\
\hline TP-3 & $01 / 31 / 2012$ & Jan. & 2012 & 727465 & 3856237 & & 37.2 & & No & 0 & 0 & 0 & 0 \\
\hline TP-3 & $01 / 31 / 2012$ & Jan. & 2012 & 727503 & 3856237 & & 42.0 & & No & 0 & 0 & 0 & 0 \\
\hline TP-3 & $01 / 31 / 2012$ & Jan. & 2012 & 727597 & 3856236 & & 45.2 & & No & 0 & 0 & 0 & 0 \\
\hline TP-2 & $01 / 31 / 2012$ & Jan. & 2012 & 726407 & 3854540 & & 21.2 & & No & 0 & 0 & 0 & 0 \\
\hline TP-2 & $01 / 31 / 2012$ & Jan. & 2012 & 726413 & 3854540 & & 19.1 & & No & 0 & 0 & 0 & 0 \\
\hline TP-2 & $01 / 31 / 2012$ & Jan. & 2012 & 726419 & 3854540 & & 20.7 & & No & 0 & 0 & 0 & 0 \\
\hline TP-2 & $01 / 31 / 2012$ & Jan. & 2012 & 726437 & 3854550 & & 23.2 & & No & 0 & 0 & 0 & 0 \\
\hline TP-2 & $01 / 31 / 2012$ & Jan. & 2012 & 726468 & 3854560 & & 18.2 & & No & 0 & 0 & 0 & 0 \\
\hline TP-2 & $01 / 31 / 2012$ & Jan. & 2012 & 726498 & 3854570 & & 16.5 & & No & 0 & 0 & 0 & 0 \\
\hline TP-2 & $01 / 31 / 2012$ & Jan. & 2012 & 726529 & 3854580 & 0.35 & 16.2 & & Yes & 0 & 1 & 0 & 0 \\
\hline TP-2 & $01 / 31 / 2012$ & Jan. & 2012 & 726559 & 3854590 & 0.39 & 26.3 & & No & 0 & 0 & 0 & 0 \\
\hline TP-2 & $01 / 31 / 2012$ & Jan. & 2012 & 726590 & 3854609 & & 29.2 & & No & 0 & 0 & 0 & 0 \\
\hline TP-2 & $01 / 31 / 2012$ & Jan. & 2012 & 726605 & 3854700 & & 50.6 & & No & 0 & 0 & 0 & 0 \\
\hline TP-2 & $01 / 31 / 2012$ & Jan. & 2012 & 726813 & 3854722 & 0.76 & 43.8 & & No & 0 & 0 & 0 & 0 \\
\hline TP-2 & $01 / 31 / 2012$ & Jan. & 2012 & 726825 & 3854722 & 0.3 & 53.6 & & No & 0 & 0 & 0 & 0 \\
\hline TP-2 & $01 / 31 / 2012$ & Jan. & 2012 & 726837 & 3854722 & 0.49 & 75.1 & & No & 0 & 0 & 0 & 0 \\
\hline
\end{tabular}


Table 8. Submerged aquatic vegetation coverage ratings along east-west transects within Topock Marsh from July 2011 to 0 ctober 2014. -Continued

[Data are presented in the order they were taken. Coverage ratings: $0=$ no vegetation, $1=<30 \%$ (low) vegetation coverage, $2=30 \%-<70 \%$ (moderate) coverage, and $3=70-100 \%$ (high) coverage. NAD 83: UTM - 11N, North American Datum of 1983 Universal Transverse Mercator - 11 degrees North; AdjEasting, adjusted easting units; m, meter; AdjNorthing, adjusted northing units; NTU, nephelometric turbidity unit; $\mathrm{cm}$, centimeter; SAV submerged aquatic vegetation; TP, sampling station; N/A, not applicable]

\begin{tabular}{|c|c|c|c|c|c|c|c|c|c|c|c|c|c|}
\hline \multirow[b]{2}{*}{$\begin{array}{l}\text { Transect } \\
\text { name }\end{array}$} & \multirow[b]{2}{*}{ Date } & \multirow[b]{2}{*}{ Month } & \multicolumn{4}{|c|}{ NAD 83: UTM - 11N } & \multirow[b]{2}{*}{$\begin{array}{l}\text { Turbitity } \\
\text { (NTUs) }\end{array}$} & \multirow[b]{2}{*}{$\begin{array}{l}\text { Secchi } \\
\text { depth } \\
\text { (cm) }\end{array}$} & \multirow[b]{2}{*}{$\begin{array}{c}\text { SAV } \\
\text { present }\end{array}$} & \multicolumn{4}{|c|}{ Coverage } \\
\hline & & & Year & $\begin{array}{l}\text { AdjEasting } \\
\text { (m) }\end{array}$ & $\begin{array}{l}\text { AdjNorthing } \\
\text { (m) }\end{array}$ & $\begin{array}{c}\text { Water } \\
\text { depth }(m)\end{array}$ & & & & $\begin{array}{l}\text { Spiny } \\
\text { naiad }^{2}\end{array}$ & $\begin{array}{l}\text { Sago } \\
\text { pond- } \\
\text { weed }^{2}\end{array}$ & Chara $^{2}$ & $\begin{array}{c}\text { Eurasian } \\
\text { water- } \\
\text { milfoil }^{2}\end{array}$ \\
\hline TP-2 & $01 / 31 / 2012$ & Jan. & 2012 & 726859 & 3854722 & & 59.5 & & No & 0 & 0 & 0 & 0 \\
\hline TP-2 & $01 / 31 / 2012$ & Jan. & 2012 & 726904 & 3854722 & 0.46 & 69.8 & & No & 0 & 0 & 0 & 0 \\
\hline TP-2 & $01 / 31 / 2012$ & Jan. & 2012 & 726950 & 3854722 & 0.40 & 67.4 & & No & 0 & 0 & 0 & 0 \\
\hline TP-2 & $01 / 31 / 2012$ & Jan. & 2012 & 727026 & 3854722 & 0.31 & 71.0 & & No & 0 & 0 & 0 & 0 \\
\hline TP-2 & $01 / 31 / 2012$ & Jan. & 2012 & 727103 & 3854722 & 0.30 & 71.4 & & No & 0 & 0 & 0 & 0 \\
\hline TP-2 & $01 / 31 / 2012$ & Jan. & 2012 & & & 0.30 & 113.0 & & No & 0 & 0 & 0 & 0 \\
\hline TP-2 & $01 / 31 / 2012$ & Jan. & 2012 & & & 0.30 & 89.3 & & No & 0 & 0 & 0 & 0 \\
\hline TP-2 & $01 / 31 / 2012$ & Jan. & 2012 & & & 0.30 & 111.0 & & No & 0 & 0 & 0 & 0 \\
\hline TP-2 & $01 / 31 / 2012$ & Jan. & 2012 & 727477 & 3854797 & 0.15 & & & No & 0 & 0 & 0 & 0 \\
\hline TP-2 & $01 / 31 / 2012$ & Jan. & 2012 & 727571 & 3854834 & 0.38 & 98.0 & & No & 0 & 0 & 0 & 0 \\
\hline TP-2 & $01 / 31 / 2012$ & Jan. & 2012 & 727664 & 3854871 & & 98.3 & & No & 0 & 0 & 0 & 0 \\
\hline TP-2 & $01 / 31 / 2012$ & Jan. & 2012 & 727901 & 3854904 & 0.41 & 70.9 & & No & 0 & 0 & 0 & 0 \\
\hline TP-1 & $01 / 31 / 2012$ & Jan. & 2012 & 726021 & 3853617 & 0.58 & 47.1 & & No & 0 & 0 & 0 & 0 \\
\hline TP-1 & $01 / 31 / 2012$ & Jan. & 2012 & 726036 & 3853617 & & 41.1 & & No & 0 & 0 & 0 & 0 \\
\hline TP-1 & $01 / 31 / 2012$ & Jan. & 2012 & 726051 & 3853617 & & 39.7 & & No & 0 & 0 & 0 & 0 \\
\hline TP-1 & $01 / 31 / 2012$ & Jan. & 2012 & 726106 & 3853617 & 0.55 & 40.1 & & No & 0 & 0 & 0 & 0 \\
\hline TP-1 & $01 / 31 / 2012$ & Jan. & 2012 & 726179 & 3853610 & 0.40 & 62.5 & & No & 0 & 0 & 0 & 0 \\
\hline TP-1 & $01 / 31 / 2012$ & Jan. & 2012 & 726251 & 3853605 & 0.49 & 55.5 & & No & 0 & 0 & 0 & 0 \\
\hline TP-1 & $01 / 31 / 2012$ & Jan. & 2012 & 726324 & 3853600 & 0.49 & 49.9 & & No & 0 & 0 & 0 & 0 \\
\hline TP-1 & $01 / 31 / 2012$ & Jan. & 2012 & 726397 & 3853595 & 0.46 & 57.8 & & No & 0 & 0 & 0 & 0 \\
\hline TP-1 & $01 / 31 / 2012$ & Jan. & 2012 & 726469 & 3853590 & & 55.5 & & No & 0 & 0 & 0 & 0 \\
\hline TP-1 & $01 / 31 / 2012$ & Jan. & 2012 & 726542 & 3853585 & 0.49 & 53.1 & & No & 0 & 0 & 0 & 0 \\
\hline TP-1 & $01 / 31 / 2012$ & Jan. & 2012 & 726614 & 3853580 & 0.58 & 54.2 & & No & 0 & 0 & 0 & 0 \\
\hline TP-1 & $01 / 31 / 2012$ & Jan. & 2012 & 726687 & 3853575 & 0.67 & 45.4 & & No & 0 & 0 & 0 & 0 \\
\hline TP-1 & $01 / 31 / 2012$ & Jan. & 2012 & 726760 & 3853570 & 0.67 & 51.1 & & No & 0 & 0 & 0 & 0 \\
\hline TP-1 & $01 / 31 / 2012$ & Jan. & 2012 & 726832 & 3853565 & 0.55 & 44.8 & & No & 0 & 0 & 0 & 0 \\
\hline TP-1 & $01 / 31 / 2012$ & Jan. & 2012 & 726892 & 3853560 & 0.46 & 41.7 & & No & 0 & 0 & 0 & 0 \\
\hline TP-1 & $01 / 31 / 2012$ & Jan. & 2012 & 726935 & 3853560 & 0.30 & 54.4 & & No & 0 & 0 & 0 & 0 \\
\hline TP-1 & $01 / 31 / 2012$ & Jan. & 2012 & 726966 & 3853560 & 0.24 & 73.7 & & No & 0 & 0 & 0 & 0 \\
\hline TP-1 & $01 / 31 / 2012$ & Jan. & 2012 & 727066 & 3853560 & 0.30 & 77.8 & & No & 0 & 0 & 0 & 0 \\
\hline TP-1 & $01 / 31 / 2012$ & Jan. & 2012 & 727167 & 3853560 & 0.52 & 65.8 & & No & 0 & 0 & 0 & 0 \\
\hline TP-1 & $01 / 31 / 2012$ & Jan. & 2012 & 727268 & 3853560 & 0.91 & 58.5 & & No & 0 & 0 & 0 & 0 \\
\hline TP-1 & $01 / 31 / 2012$ & Jan. & 2012 & 727368 & 3853560 & 0.91 & 44.6 & & No & 0 & 0 & 0 & 0 \\
\hline TP-1 & $01 / 31 / 2012$ & Jan. & 2012 & 727469 & 3853560 & 0.88 & 46.6 & & No & 0 & 0 & 0 & 0 \\
\hline TP-1 & $01 / 31 / 2012$ & Jan. & 2012 & 727569 & 3853560 & 0.82 & 67.4 & & No & 0 & 0 & 0 & 0 \\
\hline TP-1 & $01 / 31 / 2012$ & Jan. & 2012 & 727670 & 3853560 & 0.88 & 63.1 & & No & 0 & 0 & 0 & 0 \\
\hline TP-1 & $01 / 31 / 2012$ & Jan. & 2012 & 727997 & 3853592 & 0.58 & 38.8 & & No & 0 & 0 & 0 & 0 \\
\hline TP-6 & $01 / 31 / 2012$ & Jan. & 2012 & 726877 & 3850928 & 1.19 & 66.1 & & No & 0 & 0 & 0 & 0 \\
\hline TP-6 & $01 / 31 / 2012$ & Jan. & 2012 & 726889 & 3850938 & & 68.4 & & No & 0 & 0 & 0 & 0 \\
\hline TP-6 & $01 / 31 / 2012$ & Jan. & 2012 & 726901 & 3850948 & & 53.4 & & No & 0 & 0 & 0 & 0 \\
\hline TP-6 & $01 / 31 / 2012$ & Jan. & 2012 & 726926 & 3850969 & 0.91 & 63.2 & & No & 0 & 0 & 0 & 0 \\
\hline TP-6 & $01 / 31 / 2012$ & Jan. & 2012 & 726950 & 3850989 & 0.70 & 66.3 & & No & 0 & 0 & 0 & 0 \\
\hline TP-6 & $01 / 31 / 2012$ & Jan. & 2012 & 727090 & 3851105 & 0.52 & 87.3 & & No & 0 & 0 & 0 & 0 \\
\hline TP-6 & $01 / 31 / 2012$ & Jan. & 2012 & 727229 & 3851222 & 0.49 & 67.6 & & No & 0 & 0 & 0 & 0 \\
\hline TP-6 & $01 / 31 / 2012$ & Jan. & 2012 & 727369 & 3851338 & 0.52 & 63.6 & & No & 0 & 0 & 0 & 0 \\
\hline TP-6 & $01 / 31 / 2012$ & Jan. & 2012 & 727509 & 3851454 & 0.30 & 52.2 & & No & 0 & 0 & 0 & 0 \\
\hline TP-6 & $01 / 31 / 2012$ & Jan. & 2012 & 727649 & 3851571 & 0.30 & 67.2 & & Yes & 0 & 1 & 0 & 0 \\
\hline TP-6 & $01 / 31 / 2012$ & Jan. & 2012 & 727788 & 3851687 & 0.61 & 52.2 & & No & 0 & 0 & 0 & 0 \\
\hline
\end{tabular}


Table 8. Submerged aquatic vegetation coverage ratings along east-west transects within Topock Marsh from July 2011 to 0 ctober 2014. -Continued

[Data are presented in the order they were taken. Coverage ratings: $0=$ no vegetation, $1=<30 \%$ (low) vegetation coverage, $2=30 \%-<70 \%$ (moderate) coverage, and $3=70-100 \%$ (high) coverage. NAD 83: UTM - 11N, North American Datum of 1983 Universal Transverse Mercator - 11 degrees North; AdjEasting, adjusted easting units; m, meter; AdjNorthing, adjusted northing units; NTU, nephelometric turbidity unit; cm, centimeter; SAV submerged aquatic vegetation; TP, sampling station; N/A, not applicable]

\begin{tabular}{|c|c|c|c|c|c|c|c|c|c|c|c|c|c|}
\hline \multirow[b]{2}{*}{$\begin{array}{c}\text { Transect } \\
\text { name }\end{array}$} & \multirow[b]{2}{*}{ Date } & \multirow[b]{2}{*}{ Month } & \multicolumn{4}{|c|}{ NAD 83: UTM - 11N } & \multirow[b]{2}{*}{$\begin{array}{l}\text { Turbitity } \\
\text { (NTUs) }\end{array}$} & \multirow[b]{2}{*}{$\begin{array}{c}\text { Secchi } \\
\text { depth } \\
\text { (cm) }\end{array}$} & \multirow[b]{2}{*}{$\begin{array}{c}\text { SAV } \\
\text { present }\end{array}$} & \multicolumn{4}{|c|}{ Coverage } \\
\hline & & & Year & $\begin{array}{l}\text { AdjEasting } \\
\text { (m) }\end{array}$ & $\begin{array}{c}\text { AdjNorthing } \\
\text { (m) }\end{array}$ & $\begin{array}{c}\text { Water } \\
\text { depth (m) }\end{array}$ & & & & $\begin{array}{l}\text { Spiny } \\
\text { naiad }^{2}\end{array}$ & $\begin{array}{l}\text { Sago } \\
\text { pond- } \\
\text { weed }^{2}\end{array}$ & Chara $^{2}$ & $\begin{array}{c}\text { Eurasian } \\
\text { water- } \\
\text { milfoil }^{2}\end{array}$ \\
\hline TP-6 & $01 / 31 / 2012$ & Jan. & 2012 & 727928 & 3851804 & 0.23 & 57.9 & & No & 0 & 0 & 0 & 0 \\
\hline TP-6 & $01 / 31 / 2012$ & Jan. & 2012 & 728067 & 3851920 & 0.58 & 68.5 & & No & 0 & 0 & 0 & 0 \\
\hline TP-6 & $01 / 31 / 2012$ & Jan. & 2012 & 728207 & 3851984 & 0.52 & 108.0 & & No & 0 & 0 & 0 & 0 \\
\hline TP-6 & $01 / 31 / 2012$ & Jan. & 2012 & 728347 & 3851984 & 0.73 & 95.5 & & No & 0 & 0 & 0 & 0 \\
\hline TP-6 & $01 / 31 / 2012$ & Jan. & 2012 & 728486 & 3851984 & 1.01 & 84.4 & & No & 0 & 0 & 0 & 0 \\
\hline TP-6 & $01 / 31 / 2012$ & Jan. & 2012 & 728494 & 3851984 & 0.82 & 107.0 & & No & 0 & 0 & 0 & 0 \\
\hline ТP-6 & $01 / 31 / 2012$ & Jan. & 2012 & 728499 & 3851984 & 0.55 & 68.8 & & No & 0 & 0 & 0 & 0 \\
\hline TP-6 & $01 / 31 / 2012$ & Jan. & 2012 & 728506 & 3851984 & 0.46 & 76.6 & & No & 0 & 0 & 0 & 0 \\
\hline TP-6 & $01 / 31 / 2012$ & Jan. & 2012 & 728568 & 3851984 & 0.46 & & & Yes & 0 & 1 & 0 & 0 \\
\hline TP-1 & $03 / 07 / 2012$ & Mar. & 2012 & 726106 & 3853617 & 1.37 & 111.0 & & No & 0 & 0 & 0 & 0 \\
\hline TP-1 & $03 / 07 / 2012$ & Mar. & 2012 & 726112 & 3853616 & 1.37 & & & No & 0 & 0 & 0 & 0 \\
\hline TP-1 & 03/07/2012 & Mar. & 2012 & 726121 & 3853615 & 1.04 & & & No & 0 & 0 & 0 & 0 \\
\hline TP-1 & $03 / 07 / 2012$ & Mar. & 2012 & 726136 & 3853613 & 0.79 & & & No & 0 & 0 & 0 & 0 \\
\hline TP-1 & 03/07/2012 & Mar. & 2012 & 726152 & 3853611 & 0.76 & & & No & 0 & 0 & 0 & 0 \\
\hline TP-1 & $03 / 07 / 2012$ & Mar. & 2012 & 726167 & 3853609 & 0.76 & 92.1 & & No & 0 & 0 & 0 & 0 \\
\hline TP-1 & $03 / 07 / 2012$ & Mar. & 2012 & 726300 & 3853593 & 0.74 & & & No & 0 & 0 & 0 & 0 \\
\hline TP-1 & $03 / 07 / 2012$ & Mar. & 2012 & 726432 & 3853576 & 0.81 & & & No & 0 & 0 & 0 & 0 \\
\hline TP-1 & $03 / 07 / 2012$ & Mar. & 2012 & 726565 & 3853560 & 0.89 & 71.6 & & No & 0 & 0 & 0 & 0 \\
\hline TP-1 & $03 / 07 / 2012$ & Mar. & 2012 & 726698 & 3853543 & 0.86 & & & No & 0 & 0 & 0 & 0 \\
\hline TP-1 & $03 / 07 / 2012$ & Mar. & 2012 & 726831 & 3853526 & 0.86 & 137.0 & & No & 0 & 0 & 0 & 0 \\
\hline TP-1 & $03 / 07 / 2012$ & Mar. & 2012 & 726964 & 3853510 & 0.86 & 111.0 & & No & 0 & 0 & 0 & 0 \\
\hline TP-1 & $03 / 07 / 2012$ & Mar. & 2012 & 727097 & 3853493 & 0.61 & & & Yes & 0 & 1 & 0 & 0 \\
\hline TP-1 & $03 / 07 / 2012$ & Mar. & 2012 & 727229 & 3853477 & 0.76 & 109.0 & & No & 0 & 0 & 0 & 0 \\
\hline TP-1 & $03 / 07 / 2012$ & Mar. & 2012 & 727362 & 3853460 & 0.86 & 121.0 & & No & 0 & 0 & 0 & 0 \\
\hline TP-1 & $03 / 07 / 2012$ & Mar. & 2012 & 727495 & 3853443 & 1.09 & & & No & 0 & 0 & 0 & 0 \\
\hline TP-1 & 03/07/2012 & Mar. & 2012 & 727628 & 3853427 & 1.22 & & & No & 0 & 0 & 0 & 0 \\
\hline TP-1 & 03/07/2012 & Mar. & 2012 & 727761 & 3853410 & 1.22 & 97.0 & & No & 0 & 0 & 0 & 0 \\
\hline TP-1 & 03/07/2012 & Mar. & 2012 & 727893 & 3853394 & 1.12 & & & No & 0 & 0 & 0 & 0 \\
\hline TP-1 & 03/07/2012 & Mar. & 2012 & 728026 & 3853377 & 1.07 & & & No & 0 & 0 & 0 & 0 \\
\hline TP-1 & 03/07/2012 & Mar. & 2012 & 728041 & 3853375 & 0.97 & & & No & 0 & 0 & 0 & 0 \\
\hline TP-1 & 03/07/2012 & Mar. & 2012 & 728041 & 3853374 & 0.46 & & & No & 0 & 0 & 0 & 0 \\
\hline TP-1 & $03 / 07 / 2012$ & Mar. & 2012 & 728041 & 3853373 & 0.41 & & & No & 0 & 0 & 0 & 0 \\
\hline TP-1 & $03 / 07 / 2012$ & Mar. & 2012 & 728042 & 3853377 & 0.15 & 137.0 & & No & 0 & 0 & 0 & 0 \\
\hline TP-5 & $03 / 07 / 2012$ & Mar. & 2012 & 728524 & 3848098 & $0.76-0.91$ & & & No & 0 & 0 & 0 & 0 \\
\hline TP-5 & $03 / 07 / 2012$ & Mar. & 2012 & 728554 & 3848107 & 1.63 & & & No & 0 & 0 & 0 & 0 \\
\hline TP-5 & $03 / 07 / 2012$ & Mar. & 2012 & 728585 & 3848115 & 1.88 & & & No & 0 & 0 & 0 & 0 \\
\hline TP-5 & $03 / 07 / 2012$ & Mar. & 2012 & 728615 & 3848124 & 2.01 & & & No & 0 & 0 & 0 & 0 \\
\hline TP-5 & $03 / 07 / 2012$ & Mar. & 2012 & 728755 & 3848164 & 1.98 & & & No & 0 & 0 & 0 & 0 \\
\hline TP-5 & $03 / 07 / 2012$ & Mar. & 2012 & 728894 & 3848204 & 1.96 & 50.0 & & No & 0 & 0 & 0 & 0 \\
\hline TP-5 & 03/07/2012 & Mar. & 2012 & 729033 & 3848244 & 1.96 & & & No & 0 & 0 & 0 & 0 \\
\hline TP-5 & $03 / 07 / 2012$ & Mar. & 2012 & 729173 & 3848283 & 1.65 & & & No & 0 & 0 & 0 & 0 \\
\hline TP-5 & 03/07/2012 & Mar. & 2012 & 729312 & 3848323 & 1.42 & & & No & 0 & 0 & 0 & 0 \\
\hline TP-5 & $03 / 07 / 2012$ & Mar. & 2012 & 729452 & 3848363 & 0.97 & & & No & 0 & 0 & 0 & 0 \\
\hline TP-5 & 03/07/2012 & Mar. & 2012 & 729497 & 3848404 & 0.30 & 67.5 & & No & 0 & 0 & 0 & 0 \\
\hline TP-6 & $03 / 07 / 2012$ & Mar. & 2012 & 726842 & 3850960 & 0.76 & & & Yes & 0 & 1 & 0 & 0 \\
\hline TP-6 & $03 / 07 / 2012$ & Mar. & 2012 & 726872 & 3850963 & 1.07 & & & No & 0 & 0 & 0 & 0 \\
\hline ТР-6 & $03 / 07 / 2012$ & Mar. & 2012 & 726903 & 3850966 & 0.97 & & & No & 0 & 0 & 0 & 0 \\
\hline TP-6 & 03/07/2012 & Mar. & 2012 & 727055 & 3850969 & 1.07 & & & No & 0 & 0 & 0 & 0 \\
\hline
\end{tabular}


Table 8. Submerged aquatic vegetation coverage ratings along east-west transects within Topock Marsh from July 2011 to October 2014. -Continued

[Data are presented in the order they were taken. Coverage ratings: $0=$ no vegetation, $1=<30 \%$ (low) vegetation coverage, $2=30 \%-<70 \%$ (moderate) coverage, and $3=70-100 \%$ (high) coverage. NAD 83: UTM - 11N, North American Datum of 1983 Universal Transverse Mercator - 11 degrees North; AdjEasting, adjusted easting units; m, meter; AdjNorthing, adjusted northing units; NTU, nephelometric turbidity unit; $\mathrm{cm}$, centimeter; SAV submerged aquatic vegetation; TP, sampling station; N/A, not applicable]

\begin{tabular}{|c|c|c|c|c|c|c|c|c|c|c|c|c|c|}
\hline \multirow[b]{2}{*}{$\begin{array}{c}\text { Transect } \\
\text { name }\end{array}$} & \multicolumn{9}{|c|}{ NAD 83: UTM - 11N } & \multicolumn{4}{|c|}{ Coverage } \\
\hline & Date & Month & Year & $\begin{array}{l}\text { AdjEasting } \\
\text { (m) }\end{array}$ & $\begin{array}{c}\text { AdjNorthing } \\
\text { (m) }\end{array}$ & $\begin{array}{c}\text { Water } \\
\text { depth }(m)\end{array}$ & $\begin{array}{c}\text { Turbitity } \\
\text { (NTUs) }\end{array}$ & $\begin{array}{c}\text { Secchi } \\
\text { depth } \\
\text { (cm) }\end{array}$ & $\begin{array}{c}\text { SAV } \\
\text { present }\end{array}$ & $\begin{array}{l}\text { Spiny } \\
\text { naiad }^{2}\end{array}$ & $\begin{array}{l}\text { Sago } \\
\text { pond- } \\
\text { weed }^{2}\end{array}$ & Chara $^{2}$ & $\begin{array}{c}\text { Eurasian } \\
\text { water- } \\
\text { milfoil }^{2}\end{array}$ \\
\hline TP-6 & $03 / 07 / 2012$ & Mar. & 2012 & 727208 & 3850972 & 1.07 & 52.0 & & No & 0 & 0 & 0 & 0 \\
\hline TP-6 & 03/07/2012 & Mar. & 2012 & 727574 & 3850975 & 0.91 & & & No & 0 & 0 & 0 & 0 \\
\hline TP-6 & 03/07/2012 & Mar. & 2012 & 727630 & 3850978 & 0.94 & 60.2 & & No & 0 & 0 & 0 & 0 \\
\hline TP-6 & 03/07/2012 & Mar. & 2012 & 727686 & 3850981 & 1.07 & & & No & 0 & 0 & 0 & 0 \\
\hline TP-6 & $03 / 07 / 2012$ & Mar. & 2012 & 727742 & 3850984 & 1.22 & & & No & 0 & 0 & 0 & 0 \\
\hline TP-6 & $03 / 07 / 2012$ & Mar. & 2012 & 727798 & 3850987 & 0.91 & & & No & 0 & 0 & 0 & 0 \\
\hline TP-6 & $03 / 07 / 2012$ & Mar. & 2012 & 727855 & 3850990 & 1.04 & & & No & 0 & 0 & 0 & 0 \\
\hline TP-6 & $03 / 07 / 2012$ & Mar. & 2012 & 727911 & 3850993 & & 61.1 & & No & 0 & 0 & 0 & 0 \\
\hline TP-6 & $03 / 07 / 2012$ & Mar. & 2012 & 727967 & 3850996 & 1.22 & & & No & 0 & 0 & 0 & 0 \\
\hline TP-6 & $03 / 07 / 2012$ & Mar. & 2012 & 728024 & 3850999 & 1.27 & & & No & 0 & 0 & 0 & 0 \\
\hline TP-6 & 03/07/2012 & Mar. & 2012 & 728080 & 3851002 & 1.17 & 59.1 & & No & 0 & 0 & 0 & 0 \\
\hline TP-6 & 03/07/2012 & Mar. & 2012 & 728136 & 3851005 & & & & No & 0 & 0 & 0 & 0 \\
\hline TP-6 & 03/07/2012 & Mar. & 2012 & 728193 & 3851008 & 1.27 & & & No & 0 & 0 & 0 & 0 \\
\hline TP-6 & 03/07/2012 & Mar. & 2012 & 728305 & 3851009 & 1.57 & & & No & 0 & 0 & 0 & 0 \\
\hline TP-6 & 03/07/2012 & Mar. & 2012 & 728457 & 3851009 & 0.46 & & & No & 0 & 0 & 0 & 0 \\
\hline TP-3 & $07 / 22 / 2013$ & July & 2013 & 727313 & 3856304 & 0.58 & 43.0 & & Yes & 1 & 0 & 0 & 0 \\
\hline TP-3 & $07 / 22 / 2013$ & July & 2013 & 727316 & 3856307 & & & & Yes & 1 & 0 & 0 & 0 \\
\hline TP-3 & $07 / 22 / 2013$ & July & 2013 & 727318 & 3856317 & 1.18 & 32.7 & & Yes & 1 & 0 & 0 & 0 \\
\hline TP-3 & $07 / 22 / 2013$ & July & 2013 & 727331 & 3856327 & 2.93 & 31.4 & & No & 0 & 0 & 0 & 0 \\
\hline TP-3 & $07 / 22 / 2013$ & July & 2013 & 727370 & 3856337 & 1.28 & 38.7 & & No & 0 & 0 & 0 & 0 \\
\hline TP-3 & $07 / 22 / 2013$ & July & 2013 & 727410 & 3856360 & 1.13 & 31.5 & & No & 0 & 0 & 0 & 0 \\
\hline TP-3 & $07 / 22 / 2013$ & July & 2013 & 727440 & 3856347 & 1.24 & 30.8 & & No & 0 & 0 & 0 & 0 \\
\hline TP-3 & $07 / 22 / 2013$ & July & 2013 & 727454 & 3856350 & 1.25 & 30.5 & & No & 0 & 0 & 0 & 0 \\
\hline TP-3 & $07 / 22 / 2013$ & July & 2013 & 727483 & 3856357 & 1.70 & 29.6 & & No & 0 & 0 & 0 & 0 \\
\hline TP-3 & $07 / 22 / 2013$ & July & 2013 & 727503 & 3856375 & 1.40 & 32.1 & & No & 0 & 0 & 0 & 0 \\
\hline TP-3 & $07 / 22 / 2013$ & July & 2013 & 727527 & 3856387 & & & & Yes & 1 & 0 & 0 & 0 \\
\hline TP-3 & $07 / 22 / 2013$ & July & 2013 & 727552 & 3856396 & 1.20 & 34.1 & & Yes & 3 & 1 & 0 & 0 \\
\hline TP-3 & $07 / 22 / 2013$ & July & 2013 & 727557 & 3856397 & 1.00 & 26.0 & & Yes & 3 & 0 & 0 & 0 \\
\hline TP-2 & $07 / 22 / 2013$ & July & 2013 & 726388 & 3854522 & 1.20 & 14.2 & & Yes & 1 & 1 & 0 & 0 \\
\hline TP-2 & $07 / 22 / 2013$ & July & 2013 & 726391 & 3854522 & 1.45 & 14.5 & & Yes & 1 & 0 & 0 & 0 \\
\hline TP-2 & $07 / 22 / 2013$ & July & 2013 & 726393 & 3854522 & 1.65 & 16.9 & & Yes & 1 & 0 & 0 & 0 \\
\hline TP-2 & $07 / 22 / 2013$ & July & 2013 & 726403 & 3854522 & 2.80 & 13.6 & & No & 0 & 0 & 0 & 0 \\
\hline TP-2 & $07 / 22 / 2013$ & July & 2013 & 726425 & 3854520 & 2.99 & 15.7 & & No & 0 & 0 & 0 & 0 \\
\hline TP-2 & $07 / 22 / 2013$ & July & 2013 & & & 0.40 & & & No & 0 & 0 & 0 & 0 \\
\hline TP-2 & $07 / 22 / 2013$ & July & 2013 & 726477 & 3854538 & 0.94 & 19.3 & & Yes & 1 & 0 & 0 & 0 \\
\hline TP-2 & $07 / 22 / 2013$ & July & 2013 & 726520 & 3854535 & 0.94 & 21.5 & & Yes & 1 & 1 & 0 & 0 \\
\hline TP-2 & $07 / 22 / 2013$ & July & 2013 & 726563 & 3854535 & 1.04 & 19.4 & & Yes & 1 & 1 & 0 & 0 \\
\hline TP-2 & $07 / 22 / 2013$ & July & 2013 & 726606 & 3854535 & 1.01 & 25.3 & & Yes & 1 & 1 & 0 & 0 \\
\hline TP-2 & $07 / 22 / 2013$ & July & 2013 & 726648 & 3854535 & 1.07 & 26.1 & & Yes & 1 & 1 & 0 & 0 \\
\hline TP-2 & $07 / 22 / 2013$ & July & 2013 & 726691 & 3854535 & 1.04 & & & Yes & 1 & 0 & 0 & 0 \\
\hline TP-2 & $07 / 22 / 2013$ & July & 2013 & 726734 & 3854535 & 1.01 & 22.4 & & No & 0 & 0 & 0 & 0 \\
\hline TP-2 & $07 / 22 / 2013$ & July & 2013 & 726753 & 3854525 & 0.95 & 22.2 & & Yes & 0 & 1 & 0 & 1 \\
\hline TP-2 & $07 / 22 / 2013$ & July & 2013 & 727295 & 3854535 & 0.31 & 16.1 & & Yes & 1 & 1 & 0 & 0 \\
\hline TP-2 & $07 / 22 / 2013$ & July & 2013 & 727304 & 3854545 & 0.31 & 22.1 & & Yes & 1 & 0 & 0 & 0 \\
\hline TP-2 & $07 / 22 / 2013$ & July & 2013 & 727325 & 3854555 & 0.91 & 29.3 & & Yes & 1 & 0 & 0 & 0 \\
\hline TP-2 & $07 / 22 / 2013$ & July & 2013 & 727345 & 3854565 & 0.94 & 25.1 & & Yes & 1 & 0 & 0 & 0 \\
\hline TP-2 & $07 / 22 / 2013$ & July & 2013 & 727395 & 3854585 & 1.20 & 37.2 & & Yes & 1 & 0 & 0 & 0 \\
\hline TP-2 & $07 / 22 / 2013$ & July & 2013 & 727445 & 3854605 & 1.30 & 44.8 & & Yes & 1 & 0 & 0 & 0 \\
\hline
\end{tabular}


Table 8. Submerged aquatic vegetation coverage ratings along east-west transects within Topock Marsh from July 2011 to 0 ctober 2014. -Continued

[Data are presented in the order they were taken. Coverage ratings: $0=$ no vegetation, $1=<30 \%$ (low) vegetation coverage, $2=30 \%-<70 \%$ (moderate) coverage, and $3=70-100 \%$ (high) coverage. NAD 83: UTM - 11N, North American Datum of 1983 Universal Transverse Mercator - 11 degrees North; AdjEasting, adjusted easting units; m, meter; AdjNorthing, adjusted northing units; NTU, nephelometric turbidity unit; cm, centimeter; SAV submerged aquatic vegetation; TP, sampling station; N/A, not applicable]

\begin{tabular}{|c|c|c|c|c|c|c|c|c|c|c|c|c|c|}
\hline \multirow[b]{2}{*}{$\begin{array}{l}\text { Transect } \\
\text { name }\end{array}$} & \multirow[b]{2}{*}{ Date } & \multirow[b]{2}{*}{ Month } & \multicolumn{4}{|c|}{ NAD 83: UTM - 11N } & \multirow[b]{2}{*}{$\begin{array}{l}\text { Turbitity } \\
\text { (NTUs) }\end{array}$} & \multirow[b]{2}{*}{$\begin{array}{l}\text { Secchi } \\
\text { depth } \\
\text { (cm) }\end{array}$} & \multirow[b]{2}{*}{$\begin{array}{c}\text { SAV } \\
\text { present }\end{array}$} & \multicolumn{4}{|c|}{ Coverage } \\
\hline & & & Year & $\begin{array}{l}\text { AdjEasting } \\
\text { (m) }\end{array}$ & $\begin{array}{c}\text { AdjNorthing } \\
\text { (m) }\end{array}$ & $\begin{array}{c}\text { Water } \\
\text { depth (m) }\end{array}$ & & & & $\begin{array}{l}\text { Spiny } \\
\text { naiad }^{2}\end{array}$ & $\begin{array}{l}\text { Sago } \\
\text { pond- } \\
\text { weed }^{2}\end{array}$ & Chara $^{2}$ & $\begin{array}{c}\text { Eurasian } \\
\text { water- } \\
\text { milfoil }^{2}\end{array}$ \\
\hline TP-2 & $07 / 22 / 2013$ & July & 2013 & 727688 & 3854618 & 1.30 & 40.1 & & Yes & 1 & 1 & 0 & 0 \\
\hline TP-2 & $07 / 22 / 2013$ & July & 2013 & 727805 & 3854682 & 1.80 & 43.9 & & Yes & 1 & 0 & 0 & 0 \\
\hline TP-2 & $07 / 22 / 2013$ & July & 2013 & 728002 & 3854695 & 1.58 & 41.3 & & Yes & 1 & 0 & 0 & 0 \\
\hline TP-2 & $07 / 22 / 2013$ & July & 2013 & 728002 & 3854708 & 0.50 & 29.4 & & No & 0 & 0 & 0 & 0 \\
\hline TP-2 & $07 / 22 / 2013$ & July & 2013 & 728002 & 3854721 & 0.40 & 30.1 & & Yes & 1 & 1 & 0 & 0 \\
\hline TP-2 & $07 / 22 / 2013$ & July & 2013 & 728002 & 3857743 & 0.40 & 70.4 & & No & 0 & 0 & 0 & 0 \\
\hline TP-1 & $07 / 22 / 2013$ & July & 2013 & 728015 & 3853566 & 0.68 & 41.0 & & Yes & 1 & 1 & 0 & 0 \\
\hline TP-1 & $07 / 22 / 2013$ & July & 2013 & 728012 & 3853566 & 0.76 & 37.1 & & Yes & 1 & 0 & 0 & 0 \\
\hline TP-1 & $07 / 22 / 2013$ & July & 2013 & 728010 & 3853566 & 0.80 & 34.1 & & Yes & 1 & 1 & 0 & 0 \\
\hline TP-1 & $07 / 22 / 2013$ & July & 2013 & 728000 & 3853566 & 1.52 & 48.3 & & Yes & 1 & 0 & 0 & 0 \\
\hline TP-1 & $07 / 22 / 2013$ & July & 2013 & 727985 & 3853566 & 1.55 & 49.0 & & No & 0 & 0 & 0 & 0 \\
\hline TP-1 & $07 / 22 / 2013$ & July & 2013 & 727924 & 3853569 & 1.49 & 56.3 & & No & 0 & 0 & 0 & 0 \\
\hline TP-1 & $07 / 22 / 2013$ & July & 2013 & 727724 & 3853580 & 1.34 & 50.4 & & Yes & 1 & 0 & 0 & 0 \\
\hline TP-1 & $07 / 22 / 2013$ & July & 2013 & 727577 & 3853593 & 1.25 & 44.2 & & No & 0 & 0 & 0 & 0 \\
\hline TP-1 & $07 / 22 / 2013$ & July & 2013 & 727477 & 3853601 & 1.19 & 44.2 & & Yes & 2 & 0 & 0 & 0 \\
\hline TP-1 & $07 / 22 / 2013$ & July & 2013 & 727349 & 3853611 & 1.15 & 43.5 & & Yes & 3 & 0 & 0 & 0 \\
\hline TP-1 & $07 / 22 / 2013$ & July & 2013 & 727274 & 3853621 & 1.13 & 41.6 & & Yes & 3 & 0 & 0 & 0 \\
\hline TP-1 & $07 / 22 / 2013$ & July & 2013 & 727199 & 3853631 & 1.03 & 37.7 & & Yes & 3 & 0 & 0 & 0 \\
\hline TP-1 & $07 / 22 / 2013$ & July & 2013 & 727124 & 3853641 & 1.03 & 29.6 & & Yes & 3 & 0 & 0 & 0 \\
\hline TP-1 & $07 / 22 / 2013$ & July & 2013 & 727028 & 3853564 & 1.10 & 56.5 & & Yes & 3 & 0 & 0 & 0 \\
\hline TP-1 & $07 / 22 / 2013$ & July & 2013 & 726516 & 3853570 & 0.82 & 59.6 & & Yes & 3 & 0 & 0 & 0 \\
\hline TP-1 & $07 / 22 / 2013$ & July & 2013 & 727516 & 3853577 & 1.30 & 91.1 & & Yes & 2 & 0 & 0 & 1 \\
\hline TP-1 & $07 / 22 / 2013$ & July & 2013 & 726345 & 3853606 & 1.20 & 79.1 & & Yes & 1 & 1 & 0 & 2 \\
\hline TP-1 & $07 / 22 / 2013$ & July & 2013 & 726175 & 3853609 & 1.15 & 76.4 & & No & 0 & 0 & 0 & 0 \\
\hline TP-1 & $07 / 22 / 2013$ & July & 2013 & 726070 & 3853600 & 1.31 & 77.8 & & Yes & 0 & 0 & 0 & 1 \\
\hline TP-1 & $07 / 22 / 2013$ & July & 2013 & 726025 & 3853597 & 1.70 & 36.4 & & No & 0 & 0 & 0 & 0 \\
\hline TP-1 & $07 / 22 / 2013$ & July & 2013 & 726023 & 3853590 & 1.35 & 30.6 & & No & 0 & 0 & 0 & 0 \\
\hline TP-1 & $07 / 22 / 2013$ & July & 2013 & 726020 & 3853587 & 1.00 & 28.5 & & No & 0 & 0 & 0 & 0 \\
\hline TP-6 & $07 / 23 / 2013$ & July & 2013 & 726826 & 3850981 & 0.75 & 11.6 & & Yes & 0 & 1 & 0 & 0 \\
\hline ТP-6 & $07 / 23 / 2013$ & July & 2013 & 726829 & 3850988 & 0.81 & 11.8 & & Yes & 0 & 1 & 0 & 0 \\
\hline TP-6 & $07 / 23 / 2013$ & July & 2013 & 726831 & 3851002 & 0.80 & 8.4 & & Yes & 0 & 2 & 0 & 0 \\
\hline TP-6 & $07 / 23 / 2013$ & July & 2013 & 726841 & 3851016 & 1.95 & 11.1 & & Yes & 0 & 1 & 0 & 0 \\
\hline TP-6 & $07 / 23 / 2013$ & July & 2013 & 726856 & 3851030 & 1.20 & 10.7 & & No & 0 & 0 & 0 & 0 \\
\hline ТP-6 & $07 / 23 / 2013$ & July & 2013 & 726866 & 3851044 & 1.30 & 14.8 & & No & 0 & 0 & 0 & 0 \\
\hline TP-6 & $07 / 23 / 2013$ & July & 2013 & 726815 & 3851045 & & & & No & 0 & 0 & 0 & 0 \\
\hline TP-6 & $07 / 23 / 2013$ & July & 2013 & 726865 & 3851042 & 1.22 & 12.4 & & No & 0 & 0 & 0 & 0 \\
\hline TP-6 & $07 / 23 / 2013$ & July & 2013 & 726934 & 3851042 & 1.24 & 12.2 & & No & 0 & 0 & 0 & 0 \\
\hline TP-6 & $07 / 23 / 2013$ & July & 2013 & 727033 & 3851111 & 0.74 & 6.4 & & Yes & 1 & 1 & 0 & 0 \\
\hline TP-6 & $07 / 23 / 2013$ & July & 2013 & 727063 & 3851111 & 0.79 & 8.8 & & Yes & 1 & 1 & 0 & 0 \\
\hline TP-6 & $07 / 23 / 2013$ & July & 2013 & 727093 & 3851111 & 1.10 & 22.2 & & Yes & 1 & 0 & 0 & 0 \\
\hline TP-6 & $07 / 23 / 2013$ & July & 2013 & 727106 & 3851111 & 1.19 & 26.2 & & Yes & 0 & 1 & 0 & 0 \\
\hline TP-6 & $07 / 23 / 2013$ & July & 2013 & 727206 & 3851150 & 1.20 & 27.5 & 41 & Yes & 0 & 1 & 0 & 0 \\
\hline TP-6 & $07 / 23 / 2013$ & July & 2013 & 727308 & 3851191 & 1.20 & 29.0 & 41 & No & 0 & 0 & 0 & 0 \\
\hline TP-6 & $07 / 23 / 2013$ & July & 2013 & 727408 & 3851200 & 1.10 & 26.6 & & Yes & 1 & 0 & 0 & 0 \\
\hline TP-6 & $07 / 23 / 2013$ & July & 2013 & 727509 & 3851233 & 1.30 & 31.3 & 38 & Yes & 1 & 1 & 0 & 0 \\
\hline TP-6 & $07 / 23 / 2013$ & July & 2013 & 727520 & 3851240 & 1.40 & 31.5 & & Yes & 1 & 1 & 0 & 0 \\
\hline ТР-6 & $07 / 23 / 2013$ & July & 2013 & 727539 & 3851248 & 1.25 & 34.1 & & Yes & 2 & 1 & 1 & 0 \\
\hline ТP-6 & $07 / 23 / 2013$ & July & 2013 & 727739 & 3851208 & 1.60 & 33.6 & 40 & Yes & 1 & 0 & 0 & 0 \\
\hline
\end{tabular}


Table 8. Submerged aquatic vegetation coverage ratings along east-west transects within Topock Marsh from July 2011 to 0 ctober 2014. - Continued

[Data are presented in the order they were taken. Coverage ratings: $0=$ no vegetation, $1=<30 \%$ (low) vegetation coverage, $2=30 \%-<70 \%$ (moderate) coverage, and $3=70-100 \%$ (high) coverage. NAD 83: UTM - 11N, North American Datum of 1983 Universal Transverse Mercator - 11 degrees North; AdjEasting, adjusted easting units; m, meter; AdjNorthing, adjusted northing units; NTU, nephelometric turbidity unit; $\mathrm{cm}$, centimeter; SAV submerged aquatic vegetation; TP, sampling station; N/A, not applicable]

\begin{tabular}{|c|c|c|c|c|c|c|c|c|c|c|c|c|c|}
\hline \multirow[b]{2}{*}{$\begin{array}{c}\text { Transect } \\
\text { name }\end{array}$} & \multirow[b]{2}{*}{ Date } & \multirow[b]{2}{*}{ Month } & \multirow[b]{2}{*}{ Year } & \multicolumn{2}{|c|}{ NAD 83: UTM - 11N } & \multirow[b]{2}{*}{$\begin{array}{c}\text { Water } \\
\text { depth (m) }\end{array}$} & \multirow[b]{2}{*}{$\begin{array}{l}\text { Turbitity } \\
\text { (NTUs) }\end{array}$} & \multirow[b]{2}{*}{$\begin{array}{c}\text { Secchi } \\
\text { depth } \\
\text { (cm) }\end{array}$} & \multirow[b]{2}{*}{$\begin{array}{c}\text { SAV } \\
\text { present }\end{array}$} & \multicolumn{4}{|c|}{ Coverage } \\
\hline & & & & $\begin{array}{l}\text { AdjEasting } \\
\text { (m) }\end{array}$ & $\begin{array}{l}\text { AdjNorthing } \\
\text { (m) }\end{array}$ & & & & & $\begin{array}{l}\text { Spiny } \\
\text { naiad }^{2}\end{array}$ & $\begin{array}{l}\text { Sago } \\
\text { pond- } \\
\text { weed }^{2}\end{array}$ & Chara $^{2}$ & $\begin{array}{c}\text { Eurasian } \\
\text { water- } \\
\text { milfoil }^{2}\end{array}$ \\
\hline TP-6 & $07 / 23 / 2013$ & July & 2013 & 727939 & 3851168 & 1.30 & 37.2 & & Yes & 0 & 1 & 0 & 0 \\
\hline TP-6 & $07 / 23 / 2013$ & July & 2013 & 728176 & 3851115 & 1.20 & 25.5 & 48 & Yes & 0 & 1 & 0 & 0 \\
\hline TP-6 & $07 / 23 / 2013$ & July & 2013 & 728251 & 3851110 & 1.65 & 35.5 & & No & 0 & 0 & 0 & 0 \\
\hline TP-6 & $07 / 23 / 2013$ & July & 2013 & 728326 & 3851100 & 1.35 & & & No & 0 & 0 & 0 & 0 \\
\hline TP-6 & $07 / 23 / 2013$ & July & 2013 & 728401 & 3851085 & 1.15 & 36.4 & 37 & Yes & 0 & 1 & 0 & 0 \\
\hline TP-6 & $07 / 23 / 2013$ & July & 2013 & 728471 & 3851077 & 0.80 & 41.2 & & No & 0 & 0 & 0 & 0 \\
\hline TP-8 & $07 / 23 / 2013$ & July & 2013 & 730428 & 3846946 & 0.30 & 28.2 & & Yes & 0 & 0 & 2 & 0 \\
\hline TP-8 & $07 / 23 / 2013$ & July & 2013 & 730378 & 3846976 & 0.58 & 24.9 & & Yes & 0 & 1 & 1 & 0 \\
\hline TP-8 & $07 / 23 / 2013$ & July & 2013 & 730328 & 3847006 & 1.60 & 25.2 & 42 & No & 0 & 0 & 0 & 0 \\
\hline TP-8 & $07 / 23 / 2013$ & July & 2013 & 730275 & 3847022 & 1.84 & 28.9 & 39 & No & 0 & 0 & 0 & 0 \\
\hline TP-8 & $07 / 23 / 2013$ & July & 2013 & 730125 & 3847122 & 1.95 & 28.3 & & No & 0 & 0 & 0 & 0 \\
\hline TP-8 & $07 / 23 / 2013$ & July & 2013 & 729909 & 3847203 & 2.10 & 29.5 & & No & 0 & 0 & 0 & 0 \\
\hline TP-8 & $07 / 23 / 2013$ & July & 2013 & 729739 & 3847263 & 2.01 & 35.5 & 30 & No & 0 & 0 & 0 & 0 \\
\hline TP-8 & $07 / 23 / 2013$ & July & 2013 & 729579 & 3847320 & 2.10 & 44.0 & 39 & No & 0 & 0 & 0 & 0 \\
\hline TP-8 & $07 / 23 / 2013$ & July & 2013 & 729479 & 3847365 & 2.19 & 48.7 & 31 & No & 0 & 0 & 0 & 0 \\
\hline TP-8 & $07 / 23 / 2013$ & July & 2013 & 729378 & 3847392 & 2.29 & 35.1 & 31 & No & 0 & 0 & 0 & 0 \\
\hline TP-8 & $07 / 23 / 2013$ & July & 2013 & 729303 & 3847402 & 2.26 & 25.4 & 36 & No & 0 & 0 & 0 & 0 \\
\hline TP-8 & $07 / 23 / 2013$ & July & 2013 & 729228 & 3847412 & 0.87 & 25.3 & & Yes & 0 & 0 & 2 & 0 \\
\hline TP-8 & $07 / 23 / 2013$ & July & 2013 & 729153 & 3847422 & 0.87 & 25.1 & 38 & Yes & 0 & 0 & 2 & 0 \\
\hline TP-8 & $07 / 23 / 2013$ & July & 2013 & 729148 & 3847427 & 0.85 & 24.7 & & Yes & 0 & 0 & 2 & 0 \\
\hline TP-5 & $07 / 23 / 2013$ & July & 2013 & 729464 & 3848649 & 0.72 & 13.5 & 58 & Yes & 0 & 1 & 0 & 0 \\
\hline TP-5 & $07 / 23 / 2013$ & July & 2013 & 729429 & 3848642 & 0.90 & 13.6 & & Yes & 0 & 1 & 0 & 0 \\
\hline TP-5 & $07 / 23 / 2013$ & July & 2013 & 729394 & 3848632 & 1.82 & 14.6 & 52 & No & 0 & 0 & 0 & 0 \\
\hline TP-5 & $07 / 23 / 2013$ & July & 2013 & 729357 & 3848622 & 1.95 & 15.9 & & No & 0 & 0 & 0 & 0 \\
\hline TP-5 & $07 / 23 / 2013$ & July & 2013 & 729231 & 3848600 & 2.41 & 14.9 & 54 & No & 0 & 0 & 0 & 0 \\
\hline TP-5 & $07 / 23 / 2013$ & July & 2013 & 729131 & 3848572 & 2.35 & 15.7 & 55 & No & 0 & 0 & 0 & 0 \\
\hline TP-5 & $07 / 23 / 2013$ & July & 2013 & 728942 & 3848549 & 2.26 & 16.5 & & No & 0 & 0 & 0 & 0 \\
\hline TP-5 & $07 / 23 / 2013$ & July & 2013 & 728792 & 3848529 & 2.19 & 16.8 & & No & 0 & 0 & 0 & 0 \\
\hline TP-5 & $07 / 23 / 2013$ & July & 2013 & 728584 & 3848500 & 2.04 & 18.8 & & No & 0 & 0 & 0 & 0 \\
\hline TP-5 & $07 / 23 / 2013$ & July & 2013 & 728434 & 3848473 & 1.90 & 17.6 & 54 & No & 0 & 0 & 0 & 0 \\
\hline TP-5 & $07 / 23 / 2013$ & July & 2013 & 728387 & 3848470 & 0.95 & 14.5 & 57 & Yes & 0 & 1 & 0 & 0 \\
\hline TP-5 & $07 / 23 / 2013$ & July & 2013 & 728317 & 3848470 & 0.85 & & & No & 0 & 0 & 0 & 0 \\
\hline TP-5 & $07 / 23 / 2013$ & July & 2013 & 728311 & 3848470 & 0.82 & 12.0 & & No & 0 & 0 & 0 & 0 \\
\hline TP-5 & $07 / 23 / 2013$ & July & 2013 & 728297 & 3848473 & 0.73 & 11.3 & & No & 0 & 0 & 0 & 0 \\
\hline TP-5 & $07 / 23 / 2013$ & July & 2013 & 728295 & 3848473 & 0.70 & 19.7 & & Yes & 0 & 1 & 0 & 0 \\
\hline TP-5 & $07 / 23 / 2013$ & July & 2013 & 728292 & 3848479 & 0.42 & 10.8 & 42 & No & 0 & 0 & 0 & 0 \\
\hline TP-3 & $10 / 29 / 2013$ & Oct. & 2013 & 727309 & 3856304 & 0.00 & & & No & 0 & 0 & 0 & 0 \\
\hline TP-3 & $10 / 29 / 2013$ & Oct. & 2013 & 727310 & 3856304 & 0.25 & & & Yes & 1 & 1 & 0 & 0 \\
\hline TP-3 & $10 / 29 / 2013$ & Oct. & 2013 & 727312 & 3856304 & 0.60 & 21.8 & & Yes & 2 & 1 & 0 & 0 \\
\hline TP-3 & $10 / 29 / 2013$ & Oct. & 2013 & 727313 & 3856304 & 0.80 & 24.0 & & Yes & 3 & 0 & 0 & 0 \\
\hline TP-3 & $10 / 29 / 2013$ & Oct. & 2013 & 727319 & 3856300 & 2.19 & 22.1 & & No & 0 & 0 & 0 & 0 \\
\hline TP-3 & $10 / 29 / 2013$ & Oct. & 2013 & 727351 & 3856315 & 2.68 & 19.3 & & No & 0 & 0 & 0 & 0 \\
\hline TP-3 & $10 / 29 / 2013$ & Oct. & 2013 & 727382 & 3856328 & 1.20 & 14.0 & & Yes & 2 & 1 & 0 & 0 \\
\hline TP-3 & $10 / 29 / 2013$ & Oct. & 2013 & 727411 & 3856336 & 1.90 & 13.9 & & Yes & 3 & 1 & 3 & 0 \\
\hline TP-3 & $10 / 29 / 2013$ & Oct. & 2013 & 727425 & 3856343 & 0.91 & 4.3 & & Yes & 3 & 1 & 2 & 0 \\
\hline TP-3 & $10 / 29 / 2013$ & Oct. & 2013 & 727459 & 3856355 & 1.20 & 7.8 & 120 & Yes & 3 & 1 & 0 & 0 \\
\hline TP-3 & $10 / 29 / 2013$ & Oct. & 2013 & 727496 & 3856359 & 1.50 & 5.5 & & Yes & 3 & 1 & 0 & 0 \\
\hline TP-3 & $10 / 29 / 2013$ & Oct. & 2013 & 727525 & 3856362 & 1.10 & 3.6 & & Yes & 3 & 0 & 0 & 0 \\
\hline
\end{tabular}


Table 8. Submerged aquatic vegetation coverage ratings along east-west transects within Topock Marsh from July 2011 to 0 ctober 2014. -Continued

[Data are presented in the order they were taken. Coverage ratings: $0=$ no vegetation, $1=<30 \%$ (low) vegetation coverage, $2=30 \%-<70 \%$ (moderate) coverage, and $3=70-100 \%$ (high) coverage. NAD 83: UTM - 11N, North American Datum of 1983 Universal Transverse Mercator - 11 degrees North; AdjEasting, adjusted easting units; m, meter; AdjNorthing, adjusted northing units; NTU, nephelometric turbidity unit; cm, centimeter; SAV submerged aquatic vegetation; TP, sampling station; N/A, not applicable]

\begin{tabular}{|c|c|c|c|c|c|c|c|c|c|c|c|c|c|}
\hline \multirow[b]{2}{*}{$\begin{array}{l}\text { Transect } \\
\text { name }\end{array}$} & \multirow[b]{2}{*}{ Date } & \multirow[b]{2}{*}{ Month } & \multirow[b]{2}{*}{ Year } & \multicolumn{2}{|c|}{ NAD 83: UTM - 11N } & \multirow[b]{2}{*}{$\begin{array}{c}\text { Water } \\
\text { depth (m) }\end{array}$} & \multirow[b]{2}{*}{$\begin{array}{l}\text { Turbitity } \\
\text { (NTUs) }\end{array}$} & \multirow[b]{2}{*}{$\begin{array}{l}\text { Secchi } \\
\text { depth } \\
(\mathrm{cm})\end{array}$} & \multirow[b]{2}{*}{$\begin{array}{c}\text { SAV } \\
\text { present }\end{array}$} & \multicolumn{4}{|c|}{ Coverage } \\
\hline & & & & $\begin{array}{l}\text { AdjEasting } \\
\text { (m) }\end{array}$ & $\begin{array}{l}\text { AdjNorthing } \\
\text { (m) }\end{array}$ & & & & & $\begin{array}{l}\text { Spiny } \\
\text { naiad }^{2}\end{array}$ & $\begin{array}{l}\text { Sago } \\
\text { pond- } \\
\text { weed }^{2}\end{array}$ & Chara $^{2}$ & $\begin{array}{c}\text { Eurasian } \\
\text { water- } \\
\text { milfoil }^{2}\end{array}$ \\
\hline TP-3 & $10 / 29 / 2013$ & Oct. & 2013 & 727553 & 3856368 & 0.85 & 7.7 & & Yes & 3 & 2 & 0 & 0 \\
\hline TP-3 & $10 / 29 / 2013$ & Oct. & 2013 & 727558 & 3856368 & 0.90 & 5.4 & & Yes & 3 & 0 & 0 & 0 \\
\hline TP-3 & $10 / 29 / 2013$ & Oct. & 2013 & 727561 & 3856369 & 0.70 & 8.6 & & Yes & 3 & 0 & 0 & 0 \\
\hline TP-3 & $10 / 29 / 2013$ & Oct. & 2013 & 727562 & 3856369 & 0.70 & & & Yes & 3 & 0 & 0 & 0 \\
\hline TP-2 & $10 / 29 / 2013$ & Oct. & 2013 & 726389 & 3854527 & 1.00 & 16.6 & & Yes & 2 & 0 & 0 & 0 \\
\hline TP-2 & $10 / 29 / 2013$ & Oct. & 2013 & 726412 & 3854538 & 2.56 & 15.9 & & No & 0 & 0 & 0 & 0 \\
\hline TP-2 & $10 / 29 / 2013$ & Oct. & 2013 & 726477 & 3854539 & 0.76 & 25.6 & & Yes & 2 & 1 & 0 & 1 \\
\hline TP-2 & $10 / 29 / 2013$ & Oct. & 2013 & 726501 & 3854547 & 0.90 & 52.9 & & Yes & 2 & 2 & 0 & 0 \\
\hline TP-2 & $10 / 29 / 2013$ & Oct. & 2013 & 726544 & 3854545 & 0.79 & 38.8 & & Yes & 3 & 1 & 0 & 0 \\
\hline TP-2 & $10 / 29 / 2013$ & Oct. & 2013 & 726583 & 3854549 & 0.80 & 23.0 & & Yes & 3 & 0 & 0 & 0 \\
\hline TP-2 & $10 / 29 / 2013$ & Oct. & 2013 & & & 0.85 & 21.8 & & Yes & 3 & 1 & 0 & 0 \\
\hline TP-2 & $10 / 29 / 2013$ & Oct. & 2013 & & & 0.90 & 22.5 & & Yes & 2 & 1 & 0 & 0 \\
\hline TP-2 & $10 / 29 / 2013$ & Oct. & 2013 & 726726 & 3854553 & 0.85 & 22.5 & & Yes & 3 & 1 & 1 & 0 \\
\hline TP-2 & $10 / 29 / 2013$ & Oct. & 2013 & 726740 & 3854554 & 0.80 & 14.5 & & Yes & 3 & 1 & 1 & 2 \\
\hline TP-2 & $10 / 29 / 2013$ & Oct. & 2013 & & & 0.80 & 14.5 & & Yes & 2 & 0 & 0 & 0 \\
\hline TP-2 & $10 / 29 / 2013$ & Oct. & 2013 & 726998 & 3854524 & 0.65 & 16.3 & & Yes & 3 & 0 & 0 & 0 \\
\hline TP-2 & $10 / 29 / 2013$ & Oct. & 2013 & 727084 & 3854515 & 0.87 & 14.5 & & Yes & 3 & 0 & 0 & 0 \\
\hline TP-2 & $10 / 29 / 2013$ & Oct. & 2013 & 727169 & 3854528 & 0.74 & 11.3 & & Yes & 3 & 0 & 0 & 0 \\
\hline TP-2 & $10 / 29 / 2013$ & Oct. & 2013 & 727274 & 3854532 & 0.88 & 7.6 & & Yes & 3 & 0 & 0 & 0 \\
\hline TP-2 & $10 / 29 / 2013$ & Oct. & 2013 & 727423 & 3854573 & 0.80 & 19.1 & & Yes & 2 & 0 & 0 & 0 \\
\hline TP-2 & $10 / 29 / 2013$ & Oct. & 2013 & 727561 & 3854572 & 1.00 & 36.1 & & Yes & 2 & 0 & 0 & 0 \\
\hline TP-2 & $10 / 29 / 2013$ & Oct. & 2013 & 727620 & 3854560 & 0.58 & 16.2 & & Yes & 3 & 0 & 0 & 0 \\
\hline TP-2 & $10 / 29 / 2013$ & Oct. & 2013 & 727800 & 3854586 & 0.70 & 27.0 & & Yes & 3 & 0 & 0 & 0 \\
\hline TP-2 & $10 / 29 / 2013$ & Oct. & 2013 & 727909 & 3854598 & 0.90 & 74.4 & & Yes & 2 & 0 & 0 & 0 \\
\hline TP-2 & $10 / 29 / 2013$ & Oct. & 2013 & 728026 & 3854590 & 0.95 & 95.4 & & Yes & 2 & 0 & 0 & 0 \\
\hline TP-2 & $10 / 29 / 2013$ & Oct. & 2013 & 728093 & 3854593 & 0.85 & 63.3 & & Yes & 2 & 0 & 0 & 0 \\
\hline TP-1 & $10 / 29 / 2013$ & Oct. & 2013 & 727994 & 3853671 & 0.73 & 17.4 & & Yes & 2 & 0 & 0 & 0 \\
\hline TP-1 & $10 / 29 / 2013$ & Oct. & 2013 & 727918 & 3853641 & 1.28 & 33.3 & & Yes & 1 & 0 & 0 & 0 \\
\hline TP-1 & $10 / 29 / 2013$ & Oct. & 2013 & 727804 & 3853631 & 1.13 & 38.8 & 34 & Yes & 2 & 0 & 0 & 0 \\
\hline TP-1 & $10 / 29 / 2013$ & Oct. & 2013 & 727674 & 3853628 & 0.85 & 29.4 & & Yes & 2 & 0 & 0 & 0 \\
\hline TP-1 & $10 / 29 / 2013$ & Oct. & 2013 & 727505 & 3853637 & 0.76 & 17.5 & 52 & Yes & 2 & 0 & 0 & 0 \\
\hline TP-1 & $10 / 29 / 2013$ & Oct. & 2013 & 727309 & 3853633 & 0.95 & 29.5 & & Yes & 2 & 0 & 0 & 0 \\
\hline TP-1 & $10 / 29 / 2013$ & Oct. & 2013 & 727098 & 3853600 & 0.90 & 30.5 & & Yes & 2 & 0 & 0 & 0 \\
\hline TP-1 & $10 / 29 / 2013$ & Oct. & 2013 & 727008 & 3853584 & 0.75 & 15.4 & & Yes & 2 & 0 & 0 & 0 \\
\hline TP-1 & $10 / 29 / 2013$ & Oct. & 2013 & 726869 & 3853556 & 1.00 & 35.6 & 46 & Yes & 2 & 0 & 0 & 0 \\
\hline TP-1 & $10 / 29 / 2013$ & Oct. & 2013 & 726746 & 3853585 & 1.15 & 43.5 & & Yes & 2 & 0 & 0 & 1 \\
\hline TP-1 & $10 / 29 / 2013$ & Oct. & 2013 & 726559 & 3853600 & 1.10 & 52.1 & & Yes & 2 & 0 & 0 & 1 \\
\hline TP-1 & $10 / 29 / 2013$ & Oct. & 2013 & 726404 & 3853623 & 1.05 & 62.1 & & Yes & 2 & 0 & 0 & 1 \\
\hline TP-1 & $10 / 29 / 2013$ & Oct. & 2013 & 726184 & 3853640 & 0.96 & 71.2 & & Yes & 2 & 0 & 0 & 2 \\
\hline TP-1 & $10 / 29 / 2013$ & Oct. & 2013 & 726063 & 3853599 & 1.10 & 21.7 & & Yes & 2 & 0 & 0 & 2 \\
\hline TP-1 & $10 / 29 / 2013$ & Oct. & 2013 & 726020 & 3853585 & 1.22 & 15.7 & 64 & Yes & 2 & 0 & 0 & 0 \\
\hline TP-8 & $10 / 30 / 2013$ & Oct. & 2013 & N/A & N/A & 0.20 & 242.0 & & Yes & 1 & 0 & 0 & 0 \\
\hline TP-8 & $10 / 30 / 2013$ & Oct. & 2013 & 730433 & 3846923 & 0.30 & & 18 & Yes & 1 & 1 & 1 & 0 \\
\hline TP-8 & $10 / 30 / 2013$ & Oct. & 2013 & 730430 & 3846923 & 0.55 & 111.0 & 13 & Yes & 2 & 1 & 0 & 0 \\
\hline TP-8 & $10 / 30 / 2013$ & Oct. & 2013 & 730417 & 3846920 & 1.20 & 114.0 & & No & 0 & 0 & 0 & 0 \\
\hline TP-8 & $10 / 30 / 2013$ & Oct. & 2013 & 730374 & 3846942 & 1.20 & 113.0 & & Yes & 1 & 0 & 0 & 0 \\
\hline TP-8 & $10 / 30 / 2013$ & Oct. & 2013 & 730315 & 3846952 & 1.48 & 128.0 & 21 & No & 0 & 0 & 0 & 0 \\
\hline TP-8 & $10 / 30 / 2013$ & Oct. & 2013 & 730223 & 3846974 & 1.65 & 123.0 & 20 & No & 0 & 0 & 0 & 0 \\
\hline
\end{tabular}


Table 8. Submerged aquatic vegetation coverage ratings along east-west transects within Topock Marsh from July 2011 to 0 ctober 2014. -Continued

[Data are presented in the order they were taken. Coverage ratings: $0=$ no vegetation, $1=<30 \%$ (low) vegetation coverage, $2=30 \%-<70 \%$ (moderate) coverage, and $3=70-100 \%$ (high) coverage. NAD 83: UTM - 11N, North American Datum of 1983 Universal Transverse Mercator - 11 degrees North; AdjEasting, adjusted easting units; m, meter; AdjNorthing, adjusted northing units; NTU, nephelometric turbidity unit; cm, centimeter; SAV submerged aquatic vegetation; TP, sampling station; N/A, not applicable]

\begin{tabular}{|c|c|c|c|c|c|c|c|c|c|c|c|c|c|}
\hline \multicolumn{10}{|c|}{ NAD 83: UTM - 11N } & \multicolumn{4}{|c|}{ Coverage } \\
\hline $\begin{array}{l}\text { Transect } \\
\text { name }\end{array}$ & Date & Month & Year & $\begin{array}{l}\text { AdjEasting } \\
\text { (m) }\end{array}$ & $\begin{array}{c}\text { AdjNorthing } \\
\text { (m) }\end{array}$ & $\begin{array}{c}\text { Water } \\
\text { depth }(\mathrm{m})\end{array}$ & $\begin{array}{l}\text { Turbitity } \\
\text { (NTUs) }\end{array}$ & $\begin{array}{c}\text { Secchi } \\
\text { depth } \\
\text { (cm) }\end{array}$ & $\begin{array}{c}\text { SAV } \\
\text { present }\end{array}$ & $\begin{array}{l}\text { Spiny } \\
\text { naiad }^{2}\end{array}$ & $\begin{array}{l}\text { Sago } \\
\text { pond- } \\
\text { weed }^{2}\end{array}$ & Chara $^{2}$ & $\begin{array}{c}\text { Eurasian } \\
\text { water- } \\
\text { milfoil }^{2}\end{array}$ \\
\hline TP-8 & $10 / 30 / 2013$ & Oct. & 2013 & 730078 & 3846998 & 1.87 & 110.0 & & No & 0 & 0 & 0 & 0 \\
\hline TP-8 & $10 / 30 / 2013$ & Oct. & 2013 & 729885 & 3847035 & 1.95 & 125.0 & & No & 0 & 0 & 0 & 0 \\
\hline TP-8 & $10 / 30 / 2013$ & Oct. & 2013 & 729689 & 3847077 & 1.20 & 122.0 & 17 & Yes & 1 & 0 & 0 & 0 \\
\hline TP-8 & $10 / 30 / 2013$ & Oct. & 2013 & 729585 & 3847114 & 1.54 & 160.0 & 12 & No & 0 & 0 & 0 & 0 \\
\hline TP-8 & $10 / 30 / 2013$ & Oct. & 2013 & 729508 & 3847136 & 1.92 & 144.0 & 14 & No & 0 & 0 & 0 & 0 \\
\hline ТP-8 & $10 / 30 / 2013$ & Oct. & 2013 & 729461 & 3847142 & 1.95 & 147.0 & 13 & No & 0 & 0 & 0 & 0 \\
\hline TP-8 & $10 / 30 / 2013$ & Oct. & 2013 & 729405 & 3847144 & 1.83 & 164.0 & & Yes & 0 & 1 & 0 & 0 \\
\hline TP-8 & $10 / 30 / 2013$ & Oct. & 2013 & 729368 & 3847150 & 1.10 & 167.0 & & Yes & 1 & 0 & 0 & 0 \\
\hline TP-8 & $10 / 30 / 2013$ & Oct. & 2013 & 729360 & 3847148 & 0.54 & 127.0 & 17 & No & 0 & 0 & 0 & 0 \\
\hline ТP-8 & $10 / 30 / 2013$ & Oct. & 2013 & 729355 & 3847143 & 0.48 & 148.0 & & No & 0 & 0 & 0 & 0 \\
\hline TP-5 & $10 / 30 / 2013$ & Oct. & 2013 & 729467 & 3848641 & 0.30 & & 26 & No & 0 & 0 & 0 & 0 \\
\hline TP-5 & $10 / 30 / 2013$ & Oct. & 2013 & 729461 & 3848640 & 0.50 & 63.0 & & Yes & 0 & 1 & 0 & 0 \\
\hline TP-5 & $10 / 30 / 2013$ & Oct. & 2013 & 729450 & 3848637 & 1.10 & 56.0 & 29 & No & 0 & 0 & 0 & 0 \\
\hline TP-5 & $10 / 30 / 2013$ & Oct. & 2013 & 729428 & 3848635 & 1.69 & 59.0 & 27 & Yes & 1 & 0 & 0 & 0 \\
\hline TP-5 & $10 / 30 / 2013$ & Oct. & 2013 & 729357 & 3848623 & 1.80 & 61.0 & & No & 0 & 0 & 0 & 0 \\
\hline TP-5 & $10 / 30 / 2013$ & Oct. & 2013 & 729288 & 3848600 & 1.90 & 62.0 & & No & 0 & 0 & 0 & 0 \\
\hline TP-5 & $10 / 30 / 2013$ & Oct. & 2013 & 729213 & 3848555 & 2.13 & 66.0 & & Yes & 1 & 0 & 0 & 0 \\
\hline TP-5 & $10 / 30 / 2013$ & Oct. & 2013 & 729086 & 3848551 & 2.10 & 63.0 & & Yes & 1 & 0 & 0 & 0 \\
\hline TP-5 & $10 / 30 / 2013$ & Oct. & 2013 & 728955 & 3848584 & 1.98 & 61.0 & & No & 0 & 0 & 0 & 0 \\
\hline TP-5 & $10 / 30 / 2013$ & Oct. & 2013 & 728814 & 3848496 & 1.95 & 63.0 & & No & 0 & 0 & 0 & 0 \\
\hline TP-5 & $10 / 30 / 2013$ & Oct. & 2013 & 728687 & 3848404 & 1.89 & 65.0 & & No & 0 & 0 & 0 & 0 \\
\hline TP-5 & $10 / 30 / 2013$ & Oct. & 2013 & 728602 & 3848338 & 1.65 & 68.0 & & No & 0 & 0 & 0 & 0 \\
\hline TP-5 & $10 / 30 / 2013$ & Oct. & 2013 & 728495 & 3848264 & 1.83 & 70.0 & & No & 0 & 0 & 0 & 0 \\
\hline TP-5 & $10 / 30 / 2013$ & Oct. & 2013 & 728445 & 3848244 & 1.20 & 64.0 & & Yes & 2 & 0 & 0 & 0 \\
\hline TP-5 & $10 / 30 / 2013$ & Oct. & 2013 & 728395 & 3848212 & 0.50 & 68.0 & & Yes & 3 & 0 & 1 & 0 \\
\hline TP-6 & $10 / 30 / 2013$ & Oct. & 2013 & 728472 & 3851076 & 0.00 & & & No & 0 & 0 & 0 & 0 \\
\hline TP-6 & $10 / 30 / 2013$ & Oct. & 2013 & 728474 & 3851075 & 0.60 & 74.0 & & Yes & 1 & 0 & 0 & 0 \\
\hline TP-6 & $10 / 30 / 2013$ & Oct. & 2013 & 728471 & 3851078 & 1.10 & 70.0 & & Yes & 2 & 1 & 0 & 0 \\
\hline TP-6 & $10 / 30 / 2013$ & Oct. & 2013 & 728447 & 3851074 & 1.52 & 72.0 & & Yes & 1 & 0 & 0 & 0 \\
\hline TP-6 & $10 / 30 / 2013$ & Oct. & 2013 & 728381 & 3851097 & 1.68 & 74.0 & & Yes & 1 & 0 & 0 & 0 \\
\hline TP-6 & $10 / 30 / 2013$ & Oct. & 2013 & 728281 & 3851130 & 1.10 & 59.0 & & Yes & 3 & 1 & 0 & 0 \\
\hline ТP-6 & $10 / 30 / 2013$ & Oct. & 2013 & 728240 & 3851115 & 1.10 & 54.0 & & Yes & 3 & 1 & 0 & 0 \\
\hline TP-6 & $10 / 30 / 2013$ & Oct. & 2013 & 728188 & 3851114 & 0.99 & 59.0 & & Yes & 3 & 0 & 0 & 0 \\
\hline TP-6 & $10 / 30 / 2013$ & Oct. & 2013 & 728149 & 3851100 & 1.20 & 66.0 & & Yes & 1 & 1 & 0 & 0 \\
\hline TP-6 & $10 / 30 / 2013$ & Oct. & 2013 & 728101 & 3851134 & 1.48 & 68.0 & & Yes & 1 & 0 & 0 & 0 \\
\hline TP-6 & $10 / 30 / 2013$ & Oct. & 2013 & 727939 & 3851214 & 1.10 & 47.0 & & Yes & 2 & 2 & 1 & 0 \\
\hline TP-6 & $10 / 30 / 2013$ & Oct. & 2013 & 727850 & 3851168 & 1.00 & 41.0 & 33 & Yes & 3 & 1 & 1 & 0 \\
\hline TP-6 & $10 / 30 / 2013$ & Oct. & 2013 & 727784 & 3851206 & & & & No & 0 & 0 & 0 & 0 \\
\hline TP-6 & $10 / 30 / 2013$ & Oct. & 2013 & 727649 & 3851201 & 1.20 & 58.0 & & Yes & 3 & 0 & 0 & 0 \\
\hline TP-6 & $10 / 30 / 2013$ & Oct. & 2013 & 727524 & 3851233 & 1.02 & 19.0 & & Yes & 2 & 1 & 0 & 0 \\
\hline TP-6 & $10 / 30 / 2013$ & Oct. & 2013 & 727443 & 3851241 & 1.00 & 15.0 & & Yes & 3 & 0 & 0 & 0 \\
\hline TP-6 & $10 / 30 / 2013$ & Oct. & 2013 & 727395 & 3851244 & 0.80 & 7.0 & & Yes & 3 & 0 & 0 & 0 \\
\hline TP-6 & $10 / 30 / 2013$ & Oct. & 2013 & 727384 & 3851240 & 0.82 & 8.0 & & Yes & 3 & 0 & 0 & 0 \\
\hline TP-6 & $10 / 30 / 2013$ & Oct. & 2013 & 727234 & 3851200 & & & & No & 0 & 0 & 0 & 0 \\
\hline TP-6 & $10 / 30 / 2013$ & Oct. & 2013 & 727034 & 3851113 & 0.55 & 3.0 & & Yes & 2 & 1 & 1 & 0 \\
\hline TP-6 & $10 / 30 / 2013$ & Oct. & 2013 & 726955 & 3851020 & 0.90 & 8.0 & & Yes & 2 & 0 & 0 & 0 \\
\hline TP-6 & $10 / 30 / 2013$ & Oct. & 2013 & 726914 & 3850993 & 1.30 & 9.0 & & Yes & 2 & 0 & 0 & 0 \\
\hline TP-6 & $10 / 30 / 2013$ & Oct. & 2013 & 726894 & 3850988 & 1.04 & 11.0 & & Yes & 2 & 0 & 0 & 0 \\
\hline
\end{tabular}


Table 8. Submerged aquatic vegetation coverage ratings along east-west transects within Topock Marsh from July 2011 to 0 ctober 2014. -Continued

[Data are presented in the order they were taken. Coverage ratings: $0=$ no vegetation, $1=<30 \%$ (low) vegetation coverage, $2=30 \%-<70 \%$ (moderate) coverage, and $3=70-100 \%$ (high) coverage. NAD 83: UTM - 11N, North American Datum of 1983 Universal Transverse Mercator - 11 degrees North; AdjEasting, adjusted easting units; m, meter; AdjNorthing, adjusted northing units; NTU, nephelometric turbidity unit; cm, centimeter; SAV submerged aquatic vegetation; TP, sampling station; N/A, not applicable]

\begin{tabular}{|c|c|c|c|c|c|c|c|c|c|c|c|c|c|}
\hline \multirow[b]{2}{*}{$\begin{array}{c}\text { Transect } \\
\text { name }\end{array}$} & \multicolumn{9}{|c|}{ NAD 83: UTM - 11N } & \multicolumn{4}{|c|}{ Coverage } \\
\hline & Date & Month & Year & $\begin{array}{l}\text { AdjEasting } \\
\text { (m) }\end{array}$ & $\begin{array}{c}\text { AdjNorthing } \\
\text { (m) }\end{array}$ & $\begin{array}{c}\text { Water } \\
\text { depth }(m)\end{array}$ & $\begin{array}{l}\text { Turbitity } \\
\text { (NTUs) }\end{array}$ & $\begin{array}{c}\text { Secchi } \\
\text { depth } \\
\text { (cm) }\end{array}$ & $\begin{array}{c}\text { SAV } \\
\text { present }\end{array}$ & $\begin{array}{l}\text { Spiny } \\
\text { naiad }^{2}\end{array}$ & $\begin{array}{l}\text { Sago } \\
\text { pond- } \\
\text { weed }^{2}\end{array}$ & Chara $^{2}$ & $\begin{array}{c}\text { Eurasian } \\
\text { water- } \\
\text { milfoil }^{2}\end{array}$ \\
\hline TP-6 & $10 / 30 / 2013$ & Oct. & 2013 & 726874 & 3850968 & 0.61 & 13.0 & & Yes & 1 & 1 & 0 & 0 \\
\hline TP-6 & $10 / 30 / 2013$ & Oct. & 2013 & 726853 & 3850948 & 0.00 & & & No & 0 & 0 & 0 & 0 \\
\hline TP-1 & $10 / 03 / 2014$ & Oct. & 2014 & N/A & N/A & 1.60 & 35.8 & & No & 0 & 0 & 0 & 0 \\
\hline TP-1 & $10 / 03 / 2014$ & Oct. & 2014 & N/A & N/A & 1.20 & 38.0 & & No & 0 & 0 & 0 & 0 \\
\hline TP-1 & $10 / 03 / 2014$ & Oct. & 2014 & N/A & N/A & 1.00 & 32.7 & & Yes & 0 & 0 & 0 & 1 \\
\hline TP-1 & $10 / 03 / 2014$ & Oct. & 2014 & 726101 & 3853642 & 1.00 & 31.5 & & Yes & 0 & 0 & 0 & 1 \\
\hline TP-1 & $10 / 03 / 2014$ & Oct. & 2014 & 726137 & 3853661 & 1.00 & 32.5 & & No & 0 & 0 & 0 & 0 \\
\hline TP-1 & $10 / 03 / 2014$ & Oct. & 2014 & 726160 & 3853669 & 1.00 & 34.0 & & Yes & 0 & 0 & 0 & 2 \\
\hline TP-1 & $10 / 03 / 2014$ & Oct. & 2014 & 726189 & 3853666 & 1.00 & 32.9 & & No & 0 & 0 & 0 & 0 \\
\hline TP-1 & $10 / 03 / 2014$ & Oct. & 2014 & 726201 & 3853653 & 1.00 & 34.9 & & No & 0 & 0 & 0 & 0 \\
\hline TP-1 & $10 / 03 / 2014$ & Oct. & 2014 & & & 1.10 & 58.5 & & Yes & 0 & 0 & 0 & 1 \\
\hline TP-1 & $10 / 03 / 2014$ & Oct. & 2014 & & & 1.10 & 49.7 & & No & 0 & 0 & 0 & 0 \\
\hline TP-1 & $10 / 03 / 2014$ & Oct. & 2014 & & & 1.00 & 60.3 & & Yes & 0 & 0 & 0 & 2 \\
\hline TP-1 & $10 / 03 / 2014$ & Oct. & 2014 & & & 1.00 & 59.2 & & Yes & 0 & 0 & 0 & 3 \\
\hline TP-1 & $10 / 03 / 2014$ & Oct. & 2014 & & & 1.00 & 63.0 & & Yes & 0 & 0 & 0 & 2 \\
\hline TP-1 & $10 / 03 / 2014$ & Oct. & 2014 & & & 1.00 & 66.0 & & Yes & 0 & 0 & 0 & 3 \\
\hline TP-1 & $10 / 03 / 2014$ & Oct. & 2014 & & & 1.00 & 69.8 & & Yes & 0 & 0 & 0 & 2 \\
\hline TP-1 & $10 / 03 / 2014$ & Oct. & 2014 & 726411 & 3853617 & 1.00 & 89.0 & & Yes & 0 & 0 & 0 & 2 \\
\hline TP-1 & $10 / 03 / 2014$ & Oct. & 2014 & 726433 & 3853607 & 1.00 & 80.8 & & Yes & 0 & 0 & 0 & 2 \\
\hline TP-1 & $10 / 03 / 2014$ & Oct. & 2014 & 726454 & 3853599 & 1.00 & 84.5 & & Yes & 0 & 0 & 0 & 2 \\
\hline TP-1 & $10 / 03 / 2014$ & Oct. & 2014 & 726488 & 3853604 & 1.00 & 97.5 & & Yes & 0 & 0 & 0 & 2 \\
\hline TP-1 & $10 / 03 / 2014$ & Oct. & 2014 & 726531 & 3853610 & 1.00 & 101.0 & & Yes & 0 & 0 & 0 & 1 \\
\hline TP-1 & $10 / 03 / 2014$ & Oct. & 2014 & 726552 & 3853607 & 1.00 & 104.0 & & Yes & 0 & 0 & 0 & 1 \\
\hline TP-1 & $10 / 03 / 2014$ & Oct. & 2014 & 726570 & 3853599 & 1.00 & 104.0 & & No & 0 & 0 & 0 & 0 \\
\hline TP-1 & $10 / 03 / 2014$ & Oct. & 2014 & 726586 & 3853588 & 1.15 & 97.3 & & No & 0 & 0 & 0 & 0 \\
\hline TP-1 & $10 / 03 / 2014$ & Oct. & 2014 & 726661 & 3853578 & 1.00 & 99.9 & & No & 0 & 0 & 0 & 0 \\
\hline TP-1 & $10 / 03 / 2014$ & Oct. & 2014 & 726736 & 3853568 & 1.00 & 93.5 & & No & 0 & 0 & 0 & 0 \\
\hline TP-1 & $10 / 03 / 2014$ & Oct. & 2014 & 726758 & 3853565 & 1.00 & 94.8 & & No & 0 & 0 & 0 & 0 \\
\hline TP-1 & $10 / 03 / 2014$ & Oct. & 2014 & 726844 & 3853603 & 1.05 & 98.4 & & No & 0 & 0 & 0 & 0 \\
\hline TP-1 & $10 / 03 / 2014$ & Oct. & 2014 & 726845 & 3853557 & 1.00 & 104.0 & & Yes & 0 & 0 & 0 & 2 \\
\hline TP-1 & $10 / 03 / 2014$ & Oct. & 2014 & 726895 & 3853550 & 0.95 & 105.0 & & No & 0 & 0 & 0 & 0 \\
\hline TP-1 & $10 / 03 / 2014$ & Oct. & 2014 & 726945 & 3853540 & 0.80 & 106.0 & & Yes & 2 & 0 & 0 & 0 \\
\hline TP-1 & $10 / 03 / 2014$ & Oct. & 2014 & 726987 & 3853535 & 0.80 & 102.0 & & Yes & 1 & 0 & 0 & 0 \\
\hline TP-1 & $10 / 03 / 2014$ & Oct. & 2014 & 727083 & 3853592 & 0.80 & 100.0 & & Yes & 1 & 0 & 0 & 0 \\
\hline TP-1 & $10 / 03 / 2014$ & Oct. & 2014 & 727083 & 3853596 & 0.80 & 100.0 & & No & 0 & 0 & 0 & 0 \\
\hline TP-1 & $10 / 03 / 2014$ & Oct. & 2014 & 727212 & 3853712 & 0.85 & 102.0 & & No & 0 & 0 & 0 & 0 \\
\hline TP-1 & $10 / 03 / 2014$ & Oct. & 2014 & 727158 & 3853590 & 0.80 & 106.0 & & Yes & 1 & 0 & 0 & 0 \\
\hline TP-1 & $10 / 03 / 2014$ & Oct. & 2014 & 727158 & 3853590 & 0.80 & 104.0 & & No & 0 & 0 & 0 & 0 \\
\hline TP-1 & $10 / 03 / 2014$ & Oct. & 2014 & 727237 & 3853392 & 0.85 & 111.0 & & No & 0 & 0 & 0 & 0 \\
\hline TP-1 & $10 / 03 / 2014$ & Oct. & 2014 & 727324 & 3853576 & 0.90 & 114.0 & & No & 0 & 0 & 0 & 0 \\
\hline TP-1 & $10 / 03 / 2014$ & Oct. & 2014 & 727400 & 3853558 & 1.05 & 113.0 & & No & 0 & 0 & 0 & 0 \\
\hline TP-1 & $10 / 03 / 2014$ & Oct. & 2014 & 727469 & 3853539 & 1.15 & 116.0 & & No & 0 & 0 & 0 & 0 \\
\hline TP-1 & $10 / 03 / 2014$ & Oct. & 2014 & 727571 & 3853533 & 1.25 & 119.0 & & No & 0 & 0 & 0 & 0 \\
\hline TP-1 & $10 / 03 / 2014$ & Oct. & 2014 & 727593 & 3853501 & 1.30 & 118.0 & & No & 0 & 0 & 0 & 0 \\
\hline TP-1 & $10 / 03 / 2014$ & Oct. & 2014 & 727686 & 3853474 & 1.35 & 124.0 & & No & 0 & 0 & 0 & 0 \\
\hline TP-1 & $10 / 03 / 2014$ & Oct. & 2014 & 727686 & 3853460 & 1.45 & 128.0 & & No & 0 & 0 & 0 & 0 \\
\hline TP-1 & $10 / 03 / 2014$ & Oct. & 2014 & 727797 & 3853511 & 1.40 & 126.0 & & No & 0 & 0 & 0 & 0 \\
\hline TP-1 & $10 / 03 / 2014$ & Oct. & 2014 & 727849 & 3853536 & 1.45 & 129.0 & & No & 0 & 0 & 0 & 0 \\
\hline
\end{tabular}


Table 8. Submerged aquatic vegetation coverage ratings along east-west transects within Topock Marsh from July 2011 to 0 ctober 2014. - Continued

[Data are presented in the order they were taken. Coverage ratings: $0=$ no vegetation, $1=<30 \%$ (low) vegetation coverage, $2=30 \%-<70 \%$ (moderate) coverage, and $3=70-100 \%$ (high) coverage. NAD 83: UTM - 11N, North American Datum of 1983 Universal Transverse Mercator - 11 degrees North; AdjEasting, adjusted easting units; m, meter; AdjNorthing, adjusted northing units; NTU, nephelometric turbidity unit; $\mathrm{cm}$, centimeter; SAV submerged aquatic vegetation; TP, sampling station; N/A, not applicable]

\begin{tabular}{|c|c|c|c|c|c|c|c|c|c|c|c|c|c|}
\hline \multirow[b]{2}{*}{$\begin{array}{l}\text { Transect } \\
\text { name }\end{array}$} & \multirow[b]{2}{*}{ Date } & \multirow[b]{2}{*}{ Month } & \multirow[b]{2}{*}{ Year } & \multicolumn{2}{|c|}{ NAD 83: UTM - 11N } & \multirow[b]{2}{*}{$\begin{array}{c}\text { Water } \\
\text { depth }(m)\end{array}$} & \multirow[b]{2}{*}{$\begin{array}{c}\text { Turbitity } \\
\text { (NTUs) }\end{array}$} & \multirow[b]{2}{*}{$\begin{array}{c}\text { Secchi } \\
\text { depth } \\
\text { (cm) }\end{array}$} & \multirow[b]{2}{*}{$\begin{array}{c}\text { SAV } \\
\text { present }\end{array}$} & \multicolumn{4}{|c|}{ Coverage } \\
\hline & & & & $\begin{array}{l}\text { AdjEasting } \\
\text { (m) }\end{array}$ & $\begin{array}{c}\text { AdjNorthing } \\
\text { (m) }\end{array}$ & & & & & $\begin{array}{l}\text { Spiny } \\
\text { naiad }^{2}\end{array}$ & $\begin{array}{l}\text { Sago } \\
\text { pond- } \\
\text { weed }^{2}\end{array}$ & Chara $^{2}$ & $\begin{array}{c}\text { Eurasian } \\
\text { water- } \\
\text { milfoil }^{2}\end{array}$ \\
\hline TP-1 & $10 / 03 / 2014$ & Oct. & 2014 & 727908 & 3853560 & 1.40 & 119.0 & & No & 0 & 0 & 0 & 0 \\
\hline TP-1 & $10 / 03 / 2014$ & Oct. & 2014 & 727986 & 3853563 & 1.50 & 124.0 & & No & 0 & 0 & 0 & 0 \\
\hline TP-1 & $10 / 03 / 2014$ & Oct. & 2014 & 727998 & 3853573 & 1.40 & 122.0 & & No & 0 & 0 & 0 & 0 \\
\hline TP-1 & $10 / 03 / 2014$ & Oct. & 2014 & & & 0.70 & 120.0 & & Yes & 1 & 0 & 0 & 0 \\
\hline TP-6 & $10 / 03 / 2014$ & Oct. & 2014 & & & 1.65 & 35.5 & & Yes & 3 & 0 & 0 & 0 \\
\hline TP-6 & $10 / 03 / 2014$ & Oct. & 2014 & 726861 & 3851005 & 1.50 & 59.0 & & Yes & 3 & 0 & 0 & 0 \\
\hline TP-6 & $10 / 03 / 2014$ & Oct. & 2014 & 726889 & 3851000 & 1.30 & 64.3 & & Yes & 3 & 0 & 0 & 0 \\
\hline TP-6 & $10 / 03 / 2014$ & Oct. & 2014 & 726925 & 3850994 & 1.20 & 65.9 & & Yes & 3 & 0 & 0 & 0 \\
\hline TP-6 & $10 / 03 / 2014$ & Oct. & 2014 & 726971 & 3850991 & 1.00 & 82.6 & & Yes & 3 & 0 & 0 & 0 \\
\hline TP-6 & $10 / 03 / 2014$ & Oct. & 2014 & 727013 & 3850994 & 1.05 & 85.9 & & Yes & 3 & 0 & 0 & 0 \\
\hline TP-6 & $10 / 03 / 2014$ & Oct. & 2014 & 727055 & 3850995 & 1.10 & 77.9 & & Yes & 3 & 0 & 0 & 0 \\
\hline TP-6 & $10 / 03 / 2014$ & Oct. & 2014 & 727098 & 3850994 & 1.10 & 82.1 & & Yes & 3 & 0 & 0 & 0 \\
\hline TP-6 & $10 / 03 / 2014$ & Oct. & 2014 & 727147 & 3850995 & 1.10 & 90.5 & & Yes & 3 & 1 & 0 & 0 \\
\hline TP-6 & $10 / 03 / 2014$ & Oct. & 2014 & 727211 & 3850988 & 1.10 & 91.2 & & Yes & 3 & 0 & 0 & 0 \\
\hline TP-6 & $10 / 03 / 2014$ & Oct. & 2014 & 727263 & 3850992 & 1.10 & 103.0 & & Yes & 2 & 0 & 0 & 0 \\
\hline TP-6 & $10 / 03 / 2014$ & Oct. & 2014 & 727328 & 3850994 & 1.10 & 104.0 & & Yes & 1 & 0 & 0 & 0 \\
\hline TP-6 & $10 / 03 / 2014$ & Oct. & 2014 & 727385 & 3851003 & 1.05 & 109.0 & & Yes & 1 & 0 & 0 & 0 \\
\hline TP-6 & $10 / 03 / 2014$ & Oct. & 2014 & 727428 & 3851003 & 1.05 & 117.0 & & Yes & 1 & 0 & 0 & 0 \\
\hline TP-6 & $10 / 03 / 2014$ & Oct. & 2014 & 727485 & 3851009 & 1.15 & 124.0 & & No & 0 & 0 & 0 & 0 \\
\hline TP-6 & $10 / 03 / 2014$ & Oct. & 2014 & 727535 & 3851014 & 1.15 & 130.0 & & No & 0 & 0 & 0 & 0 \\
\hline TP-6 & $10 / 03 / 2014$ & Oct. & 2014 & 727593 & 3851019 & 1.13 & 134.0 & & No & 0 & 0 & 0 & 0 \\
\hline TP-6 & $10 / 03 / 2014$ & Oct. & 2014 & 727647 & 3851021 & 1.40 & 142.0 & & No & 0 & 0 & 0 & 0 \\
\hline TP-6 & $10 / 03 / 2014$ & Oct. & 2014 & 727736 & 3851093 & 1.40 & 141.0 & & No & 0 & 0 & 0 & 0 \\
\hline TP-6 & $10 / 03 / 2014$ & Oct. & 2014 & 727880 & 3851055 & 1.30 & 146.0 & & No & 0 & 0 & 0 & 0 \\
\hline TP-6 & $10 / 03 / 2014$ & Oct. & 2014 & 727888 & 3851055 & 1.30 & 138.0 & & No & 0 & 0 & 0 & 0 \\
\hline TP-6 & $10 / 03 / 2014$ & Oct. & 2014 & 727971 & 3851061 & 1.65 & 137.0 & & No & 0 & 0 & 0 & 0 \\
\hline TP-6 & $10 / 03 / 2014$ & Oct. & 2014 & 728036 & 3851078 & 1.50 & 148.0 & & No & 0 & 0 & 0 & 0 \\
\hline TP-6 & $10 / 03 / 2014$ & Oct. & 2014 & 728089 & 3851090 & 1.50 & 146.0 & & No & 0 & 0 & 0 & 0 \\
\hline TP-6 & $10 / 03 / 2014$ & Oct. & 2014 & 728143 & 3851108 & 1.35 & 130.0 & & No & 0 & 0 & 0 & 0 \\
\hline TP-6 & $10 / 03 / 2014$ & Oct. & 2014 & 728233 & 3851116 & 1.15 & 114.0 & & No & 0 & 0 & 0 & 0 \\
\hline TP-6 & $10 / 03 / 2014$ & Oct. & 2014 & 728287 & 3851122 & 1.20 & 118.0 & & No & 0 & 0 & 0 & 0 \\
\hline TP-6 & $10 / 03 / 2014$ & Oct. & 2014 & 728338 & 3851127 & 1.50 & 119.0 & & No & 0 & 0 & 0 & 0 \\
\hline TP-6 & $10 / 03 / 2014$ & Oct. & 2014 & 728386 & 3851128 & 1.80 & 121.0 & & No & 0 & 0 & 0 & 0 \\
\hline TP-6 & $10 / 03 / 2014$ & Oct. & 2014 & 728422 & 3851132 & 1.80 & 101.0 & & No & 0 & 0 & 0 & 0 \\
\hline TP-6 & $10 / 03 / 2014$ & Oct. & 2014 & 728463 & 3851141 & 1.20 & 65.0 & & No & 0 & 0 & 0 & 0 \\
\hline TP-6 & $10 / 03 / 2014$ & Oct. & 2014 & 728485 & 3851151 & 0.30 & 80.7 & & No & 0 & 0 & 0 & 0 \\
\hline TP-6 & $10 / 03 / 2014$ & Oct. & 2014 & 728491 & 3851149 & 0.30 & 113.0 & 30 & Yes & 1 & 0 & 0 & 0 \\
\hline TP-6 & $10 / 03 / 2014$ & Oct. & 2014 & 726796 & 3851017 & 1.60 & 35.0 & & Yes & 3 & 0 & 0 & 0 \\
\hline TP-6 & $10 / 03 / 2014$ & Oct. & 2014 & 726773 & 3851024 & 1.55 & 44.3 & & Yes & 3 & 0 & 0 & 0 \\
\hline TP-6 & $10 / 03 / 2014$ & Oct. & 2014 & 726746 & 3851033 & 1.50 & 51.3 & & Yes & 3 & 0 & 0 & 0 \\
\hline TP-6 & $10 / 03 / 2014$ & Oct. & 2014 & 726717 & 3851043 & 1.50 & 51.3 & & Yes & 3 & 0 & 0 & 0 \\
\hline TP-6 & $10 / 03 / 2014$ & Oct. & 2014 & 726693 & 3851051 & 1.50 & 56.1 & & Yes & 3 & 0 & 0 & 0 \\
\hline TP-6 & $10 / 03 / 2014$ & Oct. & 2014 & 726641 & 3851065 & 1.50 & 56.5 & & Yes & 3 & 0 & 0 & 0 \\
\hline TP-6 & $10 / 03 / 2014$ & Oct. & 2014 & 726579 & 3851075 & 1.50 & 63.6 & & Yes & 3 & 0 & 0 & 0 \\
\hline TP-6 & $10 / 03 / 2014$ & Oct. & 2014 & 726523 & 3851074 & 1.50 & 57.0 & & Yes & 3 & 0 & 0 & 0 \\
\hline TP-6 & $10 / 03 / 2014$ & Oct. & 2014 & 726465 & 3851059 & 1.50 & 49.1 & & Yes & 3 & 0 & 0 & 0 \\
\hline TP-6 & $10 / 03 / 2014$ & Oct. & 2014 & 726411 & 3851055 & 1.20 & 54.5 & & Yes & 3 & 0 & 0 & 0 \\
\hline TP-6 & $10 / 03 / 2014$ & Oct. & 2014 & 726377 & 3851057 & 1.20 & 62.9 & & Yes & 3 & 0 & 0 & 0 \\
\hline
\end{tabular}


Table 8. Submerged aquatic vegetation coverage ratings along east-west transects within Topock Marsh from July 2011 to 0 ctober 2014. -Continued

[Data are presented in the order they were taken. Coverage ratings: $0=$ no vegetation, $1=<30 \%$ (low) vegetation coverage, $2=30 \%-<70 \%$ (moderate) coverage, and $3=70-100 \%$ (high) coverage. NAD 83: UTM - 11N, North American Datum of 1983 Universal Transverse Mercator - 11 degrees North; AdjEasting, adjusted easting units; m, meter; AdjNorthing, adjusted northing units; NTU, nephelometric turbidity unit; cm, centimeter; SAV submerged aquatic vegetation; TP, sampling station; N/A, not applicable]

\begin{tabular}{|c|c|c|c|c|c|c|c|c|c|c|c|c|c|}
\hline \multirow[b]{2}{*}{$\begin{array}{c}\text { Transect } \\
\text { name }\end{array}$} & \multirow[b]{2}{*}{ Date } & \multirow[b]{2}{*}{ Month } & \multicolumn{3}{|c|}{ NAD 83: UTM - 11N } & \multirow[b]{2}{*}{$\begin{array}{c}\text { Water } \\
\text { depth (m) }\end{array}$} & \multirow[b]{2}{*}{$\begin{array}{l}\text { Turbitity } \\
\text { (NTUs) }\end{array}$} & \multirow[b]{2}{*}{$\begin{array}{c}\text { Secchi } \\
\text { depth } \\
\text { (cm) }\end{array}$} & \multirow[b]{2}{*}{$\begin{array}{c}\text { SAV } \\
\text { present }\end{array}$} & \multicolumn{4}{|c|}{ Coverage } \\
\hline & & & Year & $\begin{array}{l}\text { AdjEasting } \\
\text { (m) }\end{array}$ & $\begin{array}{c}\text { AdjNorthing } \\
\text { (m) }\end{array}$ & & & & & $\begin{array}{l}\text { Spiny } \\
\text { naiad }^{2}\end{array}$ & $\begin{array}{l}\text { Sago } \\
\text { pond- } \\
\text { weed }^{2}\end{array}$ & Chara $^{2}$ & $\begin{array}{c}\text { Eurasian } \\
\text { water- } \\
\text { milfoil }^{2}\end{array}$ \\
\hline TP-6 & $10 / 03 / 2014$ & Oct. & 2014 & 726353 & 3851057 & 1.40 & 50.7 & & Yes & 3 & 0 & 0 & 0 \\
\hline TP-6 & $10 / 03 / 2014$ & Oct. & 2014 & 726326 & 3851059 & 1.20 & 51.7 & & Yes & 3 & 0 & 0 & 0 \\
\hline TP-6 & $10 / 03 / 2014$ & Oct. & 2014 & 726312 & 3851061 & 0.50 & 36.7 & & Yes & 3 & 0 & 0 & 0 \\
\hline ТP-9 & $10 / 06 / 2014$ & Oct. & 2014 & 730458 & 3846839 & 0.20 & & & No & 0 & 0 & 0 & 0 \\
\hline TP-9 & $10 / 06 / 2014$ & Oct. & 2014 & & & 0.37 & 87.2 & & No & 0 & 0 & 0 & 0 \\
\hline TP-9 & $10 / 06 / 2014$ & Oct. & 2014 & & & 0.66 & 95.0 & & No & 0 & 0 & 0 & 0 \\
\hline TP-9 & $10 / 06 / 2014$ & Oct. & 2014 & & & 1.02 & 85.7 & & No & 0 & 0 & 0 & 0 \\
\hline TP-9 & $10 / 06 / 2014$ & Oct. & 2014 & & & 1.35 & 94.6 & & No & 0 & 0 & 0 & 0 \\
\hline TP-9 & $10 / 06 / 2014$ & Oct. & 2014 & & & 1.80 & 79.5 & & No & 0 & 0 & 0 & 0 \\
\hline TP-9 & $10 / 06 / 2014$ & Oct. & 2014 & & & 1.62 & 78.6 & & No & 0 & 0 & 0 & 0 \\
\hline TP-9 & $10 / 06 / 2014$ & Oct. & 2014 & & & 1.60 & 84.9 & & No & 0 & 0 & 0 & 0 \\
\hline TP-9 & $10 / 06 / 2014$ & Oct. & 2014 & 729972 & 3846791 & 1.70 & 72.8 & & Yes & 1 & 0 & 0 & 0 \\
\hline TP-9 & $10 / 06 / 2014$ & Oct. & 2014 & 730219 & 3846850 & 1.58 & 68.7 & & Yes & 0 & 1 & 0 & 0 \\
\hline TP-9 & $10 / 06 / 2014$ & Oct. & 2014 & & & 1.28 & 70.4 & & No & 0 & 0 & 0 & 0 \\
\hline ТP-9 & $10 / 06 / 2014$ & Oct. & 2014 & & & 1.00 & 71.6 & & No & 0 & 0 & 0 & 0 \\
\hline TP-9 & $10 / 06 / 2014$ & Oct. & 2014 & 729665 & 3846804 & 0.72 & 74.0 & & No & 0 & 0 & 0 & 0 \\
\hline TP-9 & $10 / 06 / 2014$ & Oct. & 2014 & 729624 & 3846842 & 0.45 & 74.0 & & No & 0 & 0 & 0 & 0 \\
\hline TP-9 & $10 / 06 / 2014$ & Oct. & 2014 & 729568 & 3846845 & 0.30 & 68.2 & & Yes & 1 & 0 & 0 & 0 \\
\hline TP-9 & $10 / 06 / 2014$ & Oct. & 2014 & 729542 & 3846861 & 0.45 & 69.2 & & Yes & 2 & 0 & 0 & 0 \\
\hline TP-9 & $10 / 06 / 2014$ & Oct. & 2014 & 729526 & 3846876 & 0.28 & 70.2 & & Yes & 2 & 1 & 0 & 0 \\
\hline TP-3 & $10 / 07 / 2014$ & Oct. & 2014 & 727330 & 3856126 & 0.60 & 47.1 & & Yes & 3 & 1 & 0 & 0 \\
\hline TP-3 & $10 / 07 / 2014$ & Oct. & 2014 & 727331 & 3856125 & 0.87 & 43.3 & & Yes & 2 & 0 & 0 & 0 \\
\hline TP-3 & $10 / 07 / 2014$ & Oct. & 2014 & 727361 & 3856118 & $>2.00$ & 37.6 & & No & 0 & 0 & 0 & 0 \\
\hline TP-3 & $10 / 07 / 2014$ & Oct. & 2014 & 727412 & 3856126 & 0.99 & 46.5 & & Yes & 0 & 0 & 1 & 0 \\
\hline TP-3 & $10 / 07 / 2014$ & Oct. & 2014 & 727431 & 3856153 & 1.00 & 54.6 & & Yes & 1 & 0 & 1 & 0 \\
\hline TP-3 & $10 / 07 / 2014$ & Oct. & 2014 & 727468 & 3856161 & 0.99 & 44.7 & & Yes & 0 & 1 & 0 & 0 \\
\hline TP-3 & $10 / 07 / 2014$ & Oct. & 2014 & 727513 & 3856160 & 1.33 & 40.1 & & Yes & 1 & 0 & 0 & 0 \\
\hline TP-3 & $10 / 07 / 2014$ & Oct. & 2014 & 727536 & 3856159 & 1.28 & 36.6 & & No & 0 & 0 & 0 & 0 \\
\hline TP-3 & $10 / 07 / 2014$ & Oct. & 2014 & 727569 & 3856154 & 1.07 & 45.1 & & Yes & 3 & 0 & 0 & 0 \\
\hline TP-3 & $10 / 07 / 2014$ & Oct. & 2014 & 727571 & 3856155 & 0.98 & 46.7 & & Yes & 2 & 0 & 0 & 0 \\
\hline TP-3 & $10 / 07 / 2014$ & Oct. & 2014 & 727584 & 3856196 & 0.81 & 25.0 & & Yes & 3 & 0 & 0 & 0 \\
\hline
\end{tabular}

${ }^{1}$ Some GPS Easting and Northing units were adjusted/corrected according to handwritten field notes. Therefore, coordinates are not precise locations but are best estimates.

${ }^{2}$ Spiny naiad = Najas marina, Sago pondweed $=$ Stuckenia pectinata, Chara $=$ Chara sp., and Eurasian watermilfoil $=$ Myriophyllum spicatum. 


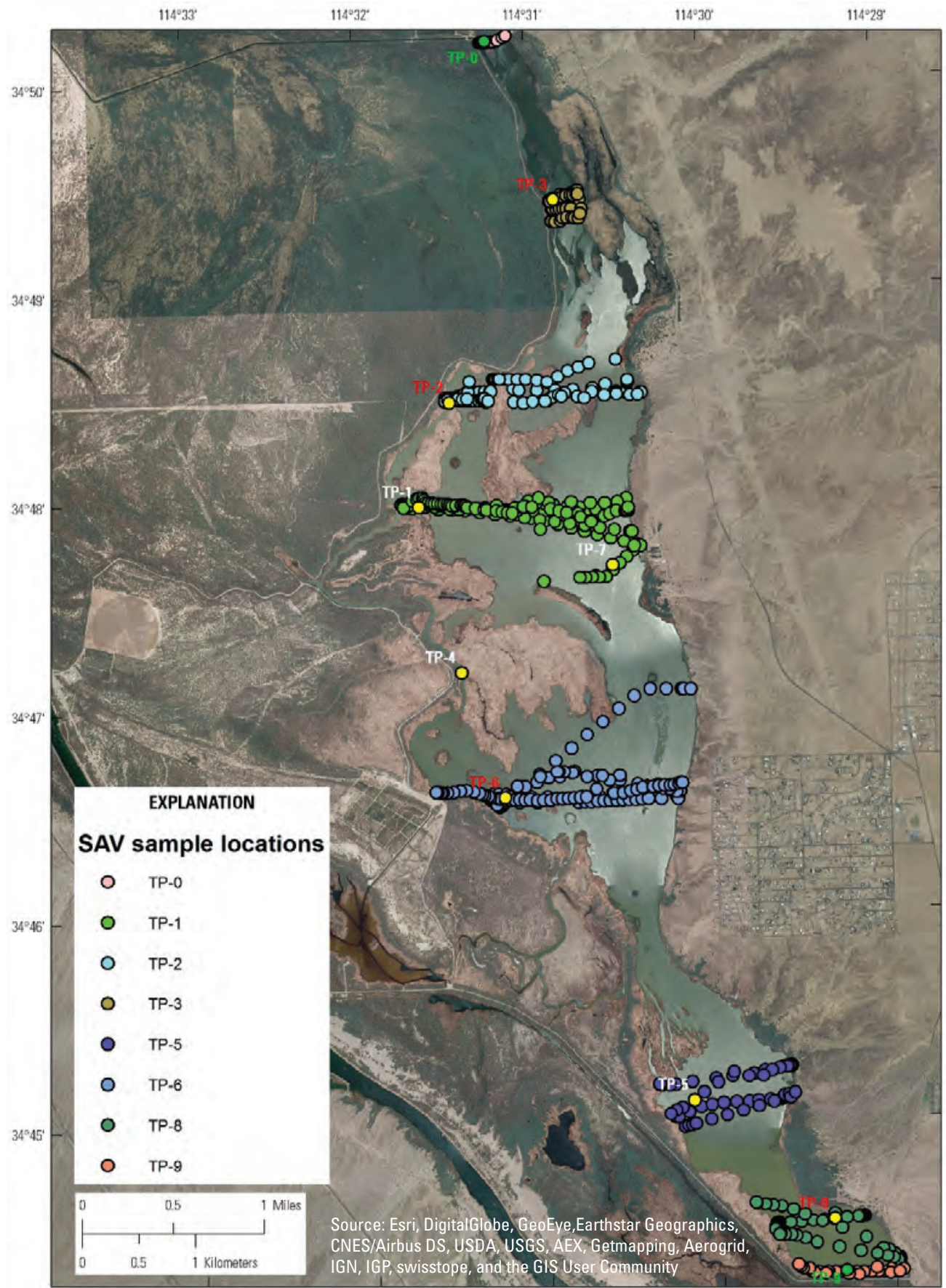

Figure 21. Submerged aquatic vegetation (SAV) sampling from July 2011 to 0ctober 2014 along transects within Topock Marsh, Arizona. (TP, sampling station). 
Table 9. Submerged aquatic vegetation presence ratios by sampling transect within Topock Marsh from October 2011 to October 2014.

[No., number; TP, sampling site]

\begin{tabular}{|c|c|c|c|c|c|c|c|}
\hline Transect & Year & Month & $\begin{array}{c}\text { No. of } \\
\text { sampling } \\
\text { points along } \\
\text { the transect }\end{array}$ & $\begin{array}{l}\text { Spiny } \\
\text { naiad }^{1}\end{array}$ & $\begin{array}{c}\text { Sago } \\
\text { pondweed }^{1}\end{array}$ & Chara $^{1}$ & $\begin{array}{c}\text { Eurasian } \\
\text { watermilfoil }^{1}\end{array}$ \\
\hline TP-0 & 2011 & Oct. & 13 & 1.00 & 0.08 & 0.00 & 0.00 \\
\hline TP-1 & 2011 & Sept. & 17 & 0.24 & 0.35 & 0.00 & 0.00 \\
\hline TP-1 & 2011 & Oct. & 29 & 0.21 & 0.07 & 0.00 & 0.00 \\
\hline TP-1 & 2012 & Jan. & 25 & 0.00 & 0.00 & 0.00 & 0.00 \\
\hline TP-1 & 2012 & Mar. & 24 & 0.00 & 0.04 & 0.00 & 0.00 \\
\hline TP-1 & 2013 & July & 22 & 0.64 & 0.14 & 0.00 & 0.14 \\
\hline TP-1 & 2013 & Oct. & 15 & 1.00 & 0.00 & 0.00 & 0.33 \\
\hline TP-1 & 2014 & Oct. & 50 & 0.10 & 0.00 & 0.00 & 0.32 \\
\hline TP-2 & 2011 & Sept. & 22 & 0.05 & 0.18 & 0.00 & 0.00 \\
\hline TP-2 & 2012 & Jan. & 25 & 0.00 & 0.04 & 0.00 & 0.00 \\
\hline TP-2 & 2013 & July & 26 & 0.73 & 0.35 & 0.00 & 0.04 \\
\hline TP-2 & 2013 & Oct. & 22 & 0.95 & 0.32 & 0.09 & 0.09 \\
\hline TP-3 & 2011 & Sept. & 16 & 0.63 & 0.13 & 0.06 & 0.00 \\
\hline TP-3 & 2012 & Jan & 10 & 0.00 & 0.00 & 0.00 & 0.00 \\
\hline TP-3 & 2013 & July & 13 & 0.46 & 0.08 & 0.00 & 0.00 \\
\hline TP-3 & 2013 & Oct. & 16 & 0.81 & 0.50 & 0.13 & 0.00 \\
\hline TP-3 & 2014 & Oct. & 11 & 0.64 & 0.18 & 0.18 & 0.00 \\
\hline TP-5 & 2011 & Sept. & 20 & 0.90 & 0.30 & 0.00 & 0.00 \\
\hline TP-5 & 2012 & Mar & 11 & 0.00 & 0.00 & 0.00 & 0.00 \\
\hline TP-5 & 2013 & July & 16 & 0.00 & 0.25 & 0.00 & 0.00 \\
\hline TP-5 & 2013 & Oct. & 15 & 0.33 & 0.07 & 0.07 & 0.00 \\
\hline TP-6 & 2011 & July & 10 & 0.90 & 0.00 & 0.00 & 0.00 \\
\hline TP-6 & 2011 & Sept. & 22 & 0.68 & 0.23 & 0.00 & 0.00 \\
\hline TP-6 & 2012 & Jan & 20 & 0.00 & 0.10 & 0.00 & 0.00 \\
\hline TP-6 & 2012 & Mar & 19 & 0.00 & 0.05 & 0.00 & 0.00 \\
\hline TP-6 & 2013 & July & 26 & 0.31 & 0.54 & 0.04 & 0.00 \\
\hline TP-6 & 2013 & Oct. & 25 & 0.84 & 0.36 & 0.12 & 0.00 \\
\hline TP-6 & 2014 & Oct. & 47 & 0.62 & 0.02 & 0.00 & 0.00 \\
\hline TP-8 & 2011 & July & 9 & 0.22 & 0.00 & 0.00 & 0.00 \\
\hline TP-8 & 2011 & Sept. & 22 & 0.91 & 0.41 & 0.00 & 0.00 \\
\hline TP-8 & 2013 & July & 14 & 0.00 & 0.07 & 0.36 & 0.00 \\
\hline TP-8 & 2013 & Oct. & 17 & 0.35 & 0.18 & 0.06 & 0.00 \\
\hline TP-9 & 2011 & Oct. & 21 & 0.57 & 0.33 & 0.05 & 0.00 \\
\hline TP-9 & 2014 & Oct. & 17 & 0.24 & 0.12 & 0.00 & 0.00 \\
\hline Total & -- & -- & 687 & -- & -- & -- & -- \\
\hline Total mean & 2011-2014 & All & -- & 0.42 & 0.17 & 0.04 & 0.03 \\
\hline
\end{tabular}

${ }^{1}$ Spiny naiad $=$ Najas marina, Sago pondweed $=$ Stuckenia pectinata, Chara $=$ Chara sp., and Eurasian watermilfoil = Myriophyllum spicatum . 


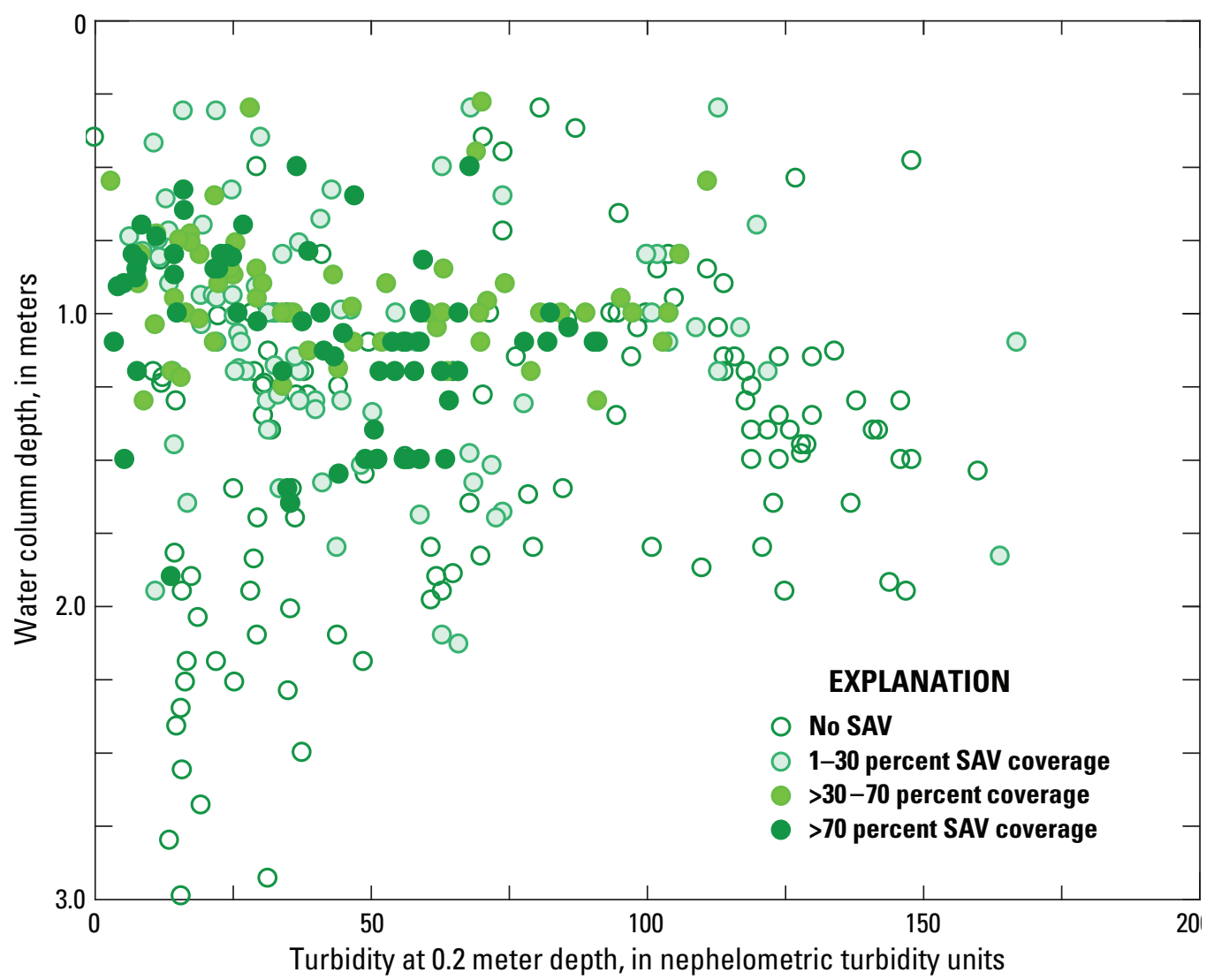

Figure 22. Scatterplot of coverage values for the submerged aquatic vegetation (SAV) in Topock Marsh, Arizona, during October 2011, October 2013, and October 2014 in relation to water depth and turbidity measurements for each observation point.

The next SAV survey was performed in July 2013 and spiny naiad coverage was recorded as low abundance to dense across the middle of the marsh (TP-1 transect), particularly in the more protected areas in water $\leq 1.3 \mathrm{~m}(\leq 4.3 \mathrm{ft})$ deep. However, similar to 2011, spiny naiad was much less abundant in open areas of the marsh even at shallow depths. Further downstream along TP-5 and TP- 8 transects, spiny naiad was not observed (tables 8 and 9). Sago pondweed, on the other hand, was scarce along the transects, with most observations being a single plant near shore in $\leq 1.0 \mathrm{~m}(\leq 3.3 \mathrm{ft})$ water depth and fairly clear water. By October 2013, however, spiny naiad became more common and even abundant across the northern transects, but remained less frequent along TP-5 and TP-8. Sago pondweed became somewhat more abundant along TP-3, TP-2, and TP-6 transects, but was uncommon elsewhere. The pattern of density and abundance of spiny naiad and sago pondweed observed in October 2013 was seen again in October 2014 with the exception that Eurasian watermilfoil, not spiny naiad, was the dominant SAV species along the TP-1 transect (tables 8 and 9).

In July 2013, one rooted Eurasian watermilfoil plant was found on the TP-2 transect, and a few more rooted plants or clumps of plants were observed along the TP-1 transect (table 8). In October 2013, more plants were observed along the western portion of the TP-2 transect and along the TP-1 transect just east of the Glory Hole area (figs. 1 and 21). By October 2014, the invasive Eurasian watermilfoil was well established and thriving throughout the area east of the Glory Hole, forming large, thick mats flowering at the water surface (table 8).

Two chara plants (Chara sp., a macroalgae) were noted in 2011 in very shallow water. However, by July 2013, a few chara patches were growing along the eastern and western edges of TP-8 in $0.86 \mathrm{~m}$ ( $2.8 \mathrm{ft})$ water depths, in $0.75 \mathrm{~m}$ $(2.5 \mathrm{ft})$ water depths along TP-5, and among a burreed (Sparganium sp.) stand growing along TP-6 in $1.25 \mathrm{~m}(4.1 \mathrm{ft})$ water depth with a turbidity of 34 NTUs (table 8). There were no flowers or other distinguishing features to identify the burreed, a macrophyte, to species. In October 2013, chara was seen growing among mesquite snags in clear water of $0.9-1.9 \mathrm{~m}(3.0-6.2 \mathrm{ft})$ water depths along TP-3, and in $0.85 \mathrm{~m}$ (2.8 ft) water depths along TP-2. Very few other chara plants were seen elsewhere in Topock Marsh (table 9).

The SAV coverage ratings $(0,1,2$, or 3$)$ recorded along each transect were plotted in relation to water depth and surface turbidity measured at each observation point in October 2011, October 2013, and October 2014 (fig. 22). This scatterplot illustrates that the highest SAV coverage clusters were present at water depths of between 0.5 and $1.5 \mathrm{~m}$ (1.6 and $4.9 \mathrm{ft}$ ) and where surface turbidities were measured at $\leq 100$ NTUs (fig. 22). Akaike's Information Criteria indicated that the best model to explain SAV coverage was the ANOVA 
of surface turbidity (as opposed to water depth). As turbidity increased, SAV decreased (ANOVA: $\mathrm{F}=43.63, \mathrm{df}=3,1$, $\mathrm{R}^{2}=0.37, p=0.007$ ). All pairwise comparison tests (that is, Tukey's Honest Significant Difference Test) were significantly different $(\mathrm{p}<0.01)$, except for the comparisons of surface turbidity between $\mathrm{SAV}=0$ and $\mathrm{SAV}=1$, and between $\mathrm{SAV}=2$ and $\mathrm{SAV}=3$.

The SAV coverage ratings and their relationship to water depth along the east-west transects are not illustrated in this report; however, the 2011-12 data were illustrated in an administrative report we previously submitted to the FWS titled "Wetland Flora, Fauna, and Water Quality Assessment at Topock MarshJuly 2011-March 2012 (J.S. Daniels and J.C. Haegele, unpub. data, 2009). Instead, the coverage ratings are listed in table 8 and our observation points are mapped on figure 21. Because Topock Marsh is too large to measure all plant coverage directly, SAV and emergent vegetation coverage was estimated using the World View 2 land cover model created by our CSU colleagues, Nick Young and Ryan Anderson. Using the model's prediction, the total area covered by SAV in October 2014 was 1.536 square kilometers $\left(\mathrm{km}^{2}\right)$ (379.6 acres) within Topock Marsh (Young and others, 2015).

\section{Emergent Aquatic Vegetation}

The two dominant emergent plant species throughout Topock Marsh were cattail (Typha sp.) and California bulrush. Common reeds (Phragmites australis) were also present and growing in at least three locations along the marsh; from 2011 to 2014, the common reed patches became noticeably larger. Various additional plants were noted at one to a few locations within the marsh but at very low densities. Those plants included the invasive giant reed (Arundo donax), Olney bulrush (Schoenoplectus americanus), river bulrush (Bolboschoenus fluviatilis), spikerush (Eleocharis sp.), smallfruit bulrush (Scirpus microcarpus), Leopold rush (Juncus acutus ssp. Leopoldii), milkweed (Asclepias sp.), and pennywort (Hydrocotyle sp.).

During vegetation surveys in 2011, it was noted that many cattail stands along the western bank of the western channel were showing signs of stress as their roots and rhizomes were high above the water line, many cattail leaves were brown, and catkins were rare [see first photo on cover page]), and in many shallow areas $(<0.6 \mathrm{~m}[<2.0 \mathrm{ft}]$ deep) new California bulrush plants had spread from established stands into deeper water. During the growing season of 2012, however, both cattail and California bulrush had a "full blown recovery with no evidence of mortality" (Rob Randall, AZFWCO, written commun., 2012). Subsequently, throughout 2013 and 2014, no signs of dieback of cattail caused by the low water depths during 2011 were observed, and both cattail and California bulrush have thrived up through our final sampling day, October 7, 2014.

Emergent vegetation coverage was calculated by plant species using the CSU land cover model. Total areal coverage of all emergent species combined was $10.662 \mathrm{~km}^{2}$ (2,634.6 acres) during October 2014 when the WorldView-2 images were taken (Young and others, 2015). Details of the methods and results of the land cover model are provided in the report by Young and others (2015).

\section{Phytoplankton}

The phytoplankton taxa found in this study are listed in table 10. Species richness during the entire 4-year study was 240 individual phytoplankton taxa (table 10). During the low water sampling period (August 2011-March 2012), 193 individual phytoplankton taxa were found, however, species richness in a given sample ranged from 15 to 52 depending on the location and month (table 10). During this time, phytoplankton density stayed relatively low, with the exception of a large number of blue-green algae (Cyanobacteria) cells that appeared in October 2011 at TP-8 (fig. 23A). However, even though individual numbers were low, phytoplankton biovolume at TP- 6 reached as high as 4 million $\mu \mathrm{m}^{3} / \mathrm{mL}$ and 6 million $\mu \mathrm{m}^{3} / \mathrm{mL}$ in February and March 2012, respectively, with diatoms (Bacillariophyceae) making up 98 percent of the total cells (fig. 23B).

During the high-water sampling period (June 2013October 2014), species richness of phytoplankton was nearly 50 percent lower than in 2011-12 (number of taxa $=100$ ) (table 10), but cell densities and biovolume far exceeded those collected in 2011-12. Taxa responsible for the highest biovolumes varied between dinoflagellates (Pyrrophycophyta), blue-green algae, golden-brown algae (Chrysophyta), and diatoms at TP-3, TP-2, TP-6, and TP-8, respectively (fig. 23B). Taxa generating the highest cell density during that period was golden-brown algae at TP-3, and blue-green algae at TP-2, TP-3, and TP-8 (fig. 23A).

Overall, total phytoplankton density and biovolume were greatest during July 2013 at TP-8 (figs. $23 A$ and $B$ ) immediately following the hottest air temperatures of the study period (fig. $3 A$ ). At that time, diatoms made up more than 43 percent of the total phytoplankton biovolume, blue-green algae made up more than 32 percent, and green algae (Chlorophyta) made up more than 18 percent (fig. 23B). Plankton were not sampled during the hottest months in 2014.

\section{Zooplankton}

The zooplankton taxa found in Topock Marsh at each sampling station and for each sampling date are listed in table 11. Species richness for zooplankton during the 4-year study period included 67 different taxa (table 11). Figures $24 \mathrm{~A}$ and $B$ illustrate the density and biomass of zooplankton by date and location. The highest density and biomass of zooplankton were observed in February 2014, and TP-6 had the highest cell density and biomass values that month. The second highest density and biomass occurred in April 2014. Rotifers (Rotifera) had the highest densities in February and April 2014 at all sampling locations, but cladocerans (Cladocera) made up the majority of the biomass. 
Table 10. Phytoplankton taxa collected in Topock Marsh at each sample station on each sampling date.

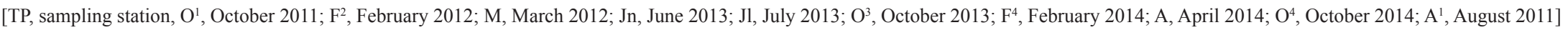

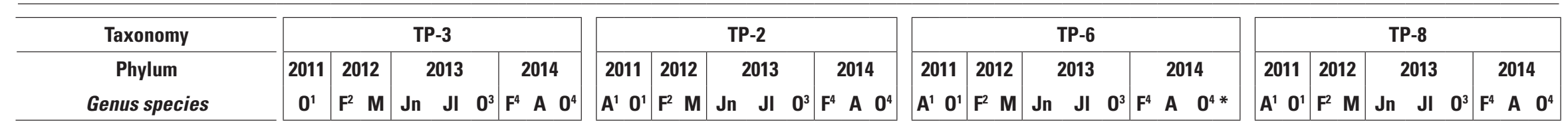

BACILLARIOPHYTA (diatoms)

Achnanthidium duthiei

Achnanthidium minutissimum

Achnanthidium spp.

Amphipleura pellucida

Amphiprora spp.

Amphora libyca

Amphora ovalis

Amphora sp.

Anomoeoneis sphaerophora

Aulacoseira granulata

Aulacoseira sp.

Brachysira sp.

Caloneis bacillum

Caloneis cf. pulchra

Caloneis limosa

Caloneis schumanniana

Caloneis silicula

Caloneis westii

Caloneis sp.

Cocconeis placentula

Craticula ambigua

Craticula buderi

Craticula cuspidata

Craticula molesta

Cyclotella cf. comensis

Cyclotella comensis

Cyclotella gamma

Cyclotella ocellata

Cyclotella sp.

Cymatopleura elliptica

Cymatopleura solea

Cymbella affinis

Cymbella delicatula

Cymbella naviculiformis
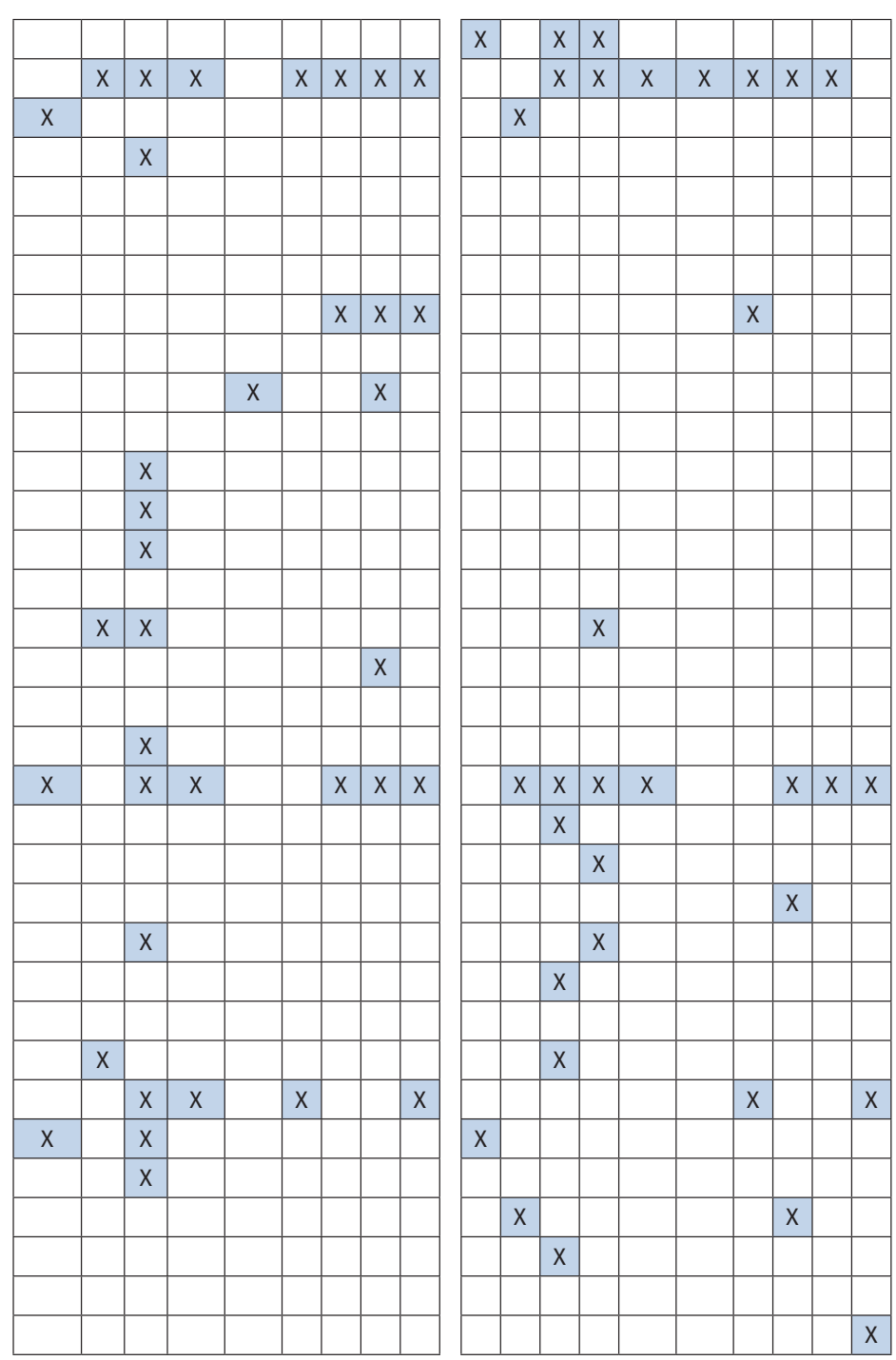

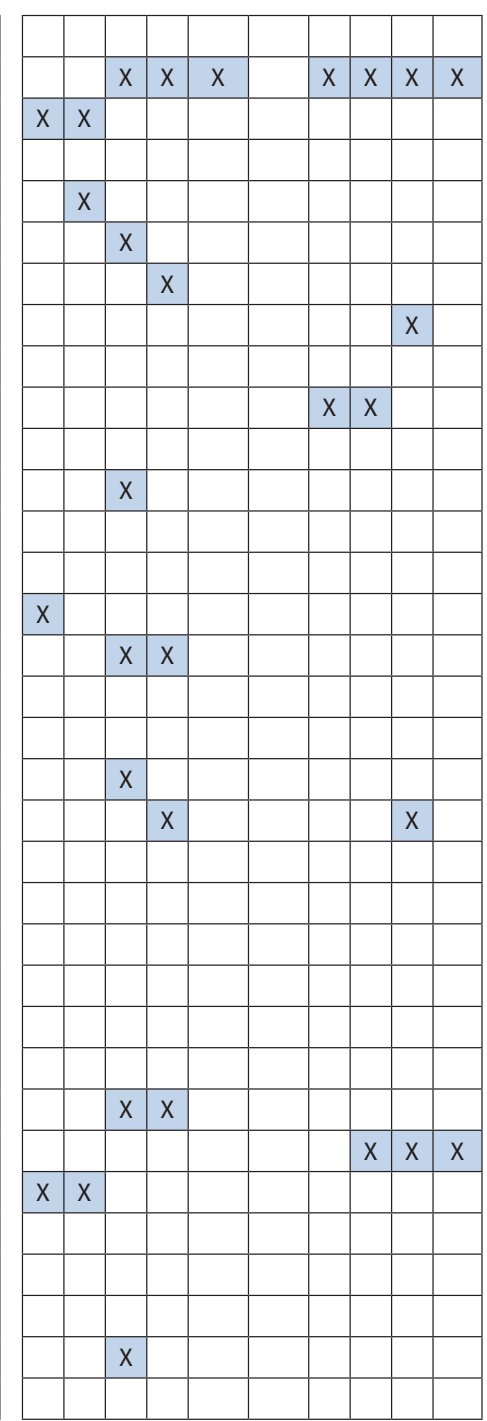


Table 10. Phytoplankton taxa collected in Topock Marsh at each sample station on each sampling date.-Continued

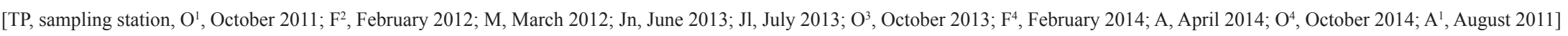

\begin{tabular}{|c|c|c|c|c|c|c|c|c|c|c|c|c|c|c|c|c|c|c|c|c|c|c|c|c|c|c|c|c|c|c|c|c|c|c|c|c|c|c|c|}
\hline \multirow{3}{*}{$\begin{array}{c}\text { Taxonomy } \\
\text { Phylum } \\
\text { Genus species }\end{array}$} & \multicolumn{9}{|c|}{ TP-3 } & \multicolumn{10}{|c|}{ TP-2 } & \multicolumn{11}{|c|}{ TP-6 } & \multicolumn{9}{|c|}{ TP-8 } \\
\hline & \multirow{2}{*}{$\begin{array}{c}2011 \\
0^{1} \\
\end{array}$} & \multirow{2}{*}{\multicolumn{2}{|c|}{$\begin{array}{cc}2012 \\
F^{2} & M \\
\end{array}$}} & \multicolumn{3}{|c|}{2013} & \multicolumn{3}{|c|}{2014} & \multirow{2}{*}{\multicolumn{2}{|c|}{$\begin{array}{|ll|}2011 \\
A^{1} & 0^{1} \\
\end{array}$}} & & 2012 & & 013 & & & 2014 & & 20 & 11 & 20 & 12 & & 2013 & & & & 14 & & & 011 & 20 & 112 & & 2013 & & 2014 & \\
\hline & & & & Jn & Jl & $0^{3}$ & $\mathbf{F}^{4}$ & A & $\mathbf{0}^{4}$ & & & & ${ }^{2} \mathbf{M}$ & Jn & Jl & $0^{3}$ & $F^{4}$ & A & $0^{4}$ & & $0^{1}$ & & $\mathbf{M}$ & Jn & لl & $0^{3}$ & $F^{4}$ & A & & )$^{4 *}$ & & $0^{1}$ & & $\mathbf{M}$ & Jn & Jl & $0^{3}$ & $F^{4} \quad A$ & $0^{4}$ \\
\hline Cymbella proxima & & & & & & & & $x$ & & & & & & & $x$ & & & $x$ & & & & & & & & & & & & & & & & & & & & & \\
\hline Cymbella sp. & & & $\mathrm{x}$ & & & & & & & & $x$ & & & & & & & & & $\mathrm{X}$ & & & $\mathrm{x}$ & & & & & & & & & & & & & & & & \\
\hline Cymbopleura frequens & & & & & & & & & & & & & $x$ & & & & & & & & & & & & & & & & & & & & & & & & & & \\
\hline Denticula cf. elegans & & & & & & & & & & & & $x$ & r & & & & & & & & & & & & & & & & & & & & & & & & & & \\
\hline Denticula sp. & & & & & & & & $x$ & & & & & & & & & & & & & & & & & & & & $x$ & $x$ & $x$ & & & & & & & & & \\
\hline Diadesmis contenta & & & & & & & & & & & & $x$ & < & & & & & & & & & & & & & & & & & & & & & & & & & & \\
\hline Diatoma moniliformis & & & & & & & & & & & & $x$ & < & $x$ & & $\mathrm{x}$ & & $x$ & & & & & & & & & & & & & & & & & & & & & \\
\hline Diatoma tenuis & & & & & & & & & & & & & $x$ & & & & & & & & & & & & & & & & & & & & & & & & & & \\
\hline Diatoma vulgare or vulgaris & & & & & & & & & & $x$ & $\mathrm{x}$ & & & & & & & & & $\mathrm{x}$ & $x$ & & & & & & $\mathrm{x}$ & & & & & & & & & & & & \\
\hline Diploneis elliptica & & & & & & $\mathrm{x}$ & & & & & & & $\mathrm{x}$ & & & & & & & & & & $\mathrm{x}$ & & & & & & & & & & & $x$ & & & & & \\
\hline Diploneis oblongella & & & $\mathrm{x}$ & & & & & & & & & & & & & & & & & & & & & & & & & & & & & & & & & & & & \\
\hline Diploneis ovalis & & & & & & & & & & & & & & & & & & & & & & & & & & & & & & & & & & & & & & $x$ & \\
\hline Diploneis parma & & & & & $x$ & & $x$ & & & & & & & & & & $x$ & & $x$ & & & & & & & & $x$ & & & & & & & & & & & & \\
\hline Diploneis puella & & $x$ & & & & & & & & & & & & & & & & & & & & & & & & & & & & & & & & & & & & & \\
\hline Diploneis sp. & & & & & & & & & $x$ & & & $x$ & < & & & & & & & & & & & & & & & & & & & & & & & & & & \\
\hline Encyonema minutum & & & & & & & $x$ & $x$ & $x$ & & $x$ & & $x$ & & & $\mathrm{x}$ & $x$ & $x$ & & $x$ & & & & & & $\mathrm{x}$ & $x$ & $x$ & & & & & & & & & & $x$ & \\
\hline Encyonema sp. & $x$ & & & & & & & & & & $x$ & & & $x$ & & & & & & & $x$ & & & & & & & & & & & & & & & & & & \\
\hline Encyonopsis microcephala & & & & & & & & & & & & $x$ & r & & & & & & & & & $x$ & $x$ & & & & & & & & & & & & & & & & \\
\hline Entomoneis sp. & & & $\mathrm{x}$ & & & & & & & & & & $x$ & & & & & & & & & $x$ & $x$ & & & & & & & & & & $\mathrm{x}$ & $\mathrm{X}$ & & & & & \\
\hline Epithemia sp. & & & & & & & & & & & & & & & & & & & & & $x$ & & $x$ & & & & & & & & & & & & & & & & \\
\hline Eunotia exigua & & & & & & & & & & & & & & & & & & & & & & & & & & & & & & & & & & $x$ & & & & & \\
\hline Eunotia sp. & & & & & & & & & & & & $x$ & < & & & & & & & $x$ & & & & & & & & & & & & & & & & & & & \\
\hline Fallacia pygmaea & & & $x$ & & & & & & & & & & & & & & & & & & & & & & & & & & & & & & & & & & & & \\
\hline Fragilaria bidens & & & & & & & & & & & & & & & & & & & & & & & $\mathrm{x}$ & & & & & & & & & & & & & & & & \\
\hline Fragilaria capucina & & $x$ & $x$ & & & $x$ & $x$ & & $x$ & $x$ & $x$ & $x$ & r & $x$ & & $x$ & $x$ & $x$ & $x$ & $x$ & $x$ & $\mathrm{x}$ & & & & $x$ & $\mathrm{x}$ & $x$ & & $x$ & $x$ & $x$ & $x$ & & $x$ & $x$ & & $\mathrm{x}$ & $x$ \\
\hline $\begin{array}{l}\text { Fragilaria capucina var. } \\
\quad \text { gracilis }\end{array}$ & & & & & & & & & & & & $x$ & k & & & & & & & & & & & & & & & & & & & & & & & & & & \\
\hline Fragilaria construens & & & & & & & & & & & & & & & & & & & & $x$ & & & & & & & & & & & & & & & & & & & \\
\hline Fragilaria crotonensis & & & & $x$ & $\mathrm{x}$ & & & & & & & & $x$ & $x$ & $x$ & & & & & & & & & & & & & & & & & & & & & & & & \\
\hline Fragilaria sp. & $x$ & & & & & & & & & $x$ & & & & & & & & & & $\mathrm{X}$ & $x$ & & & & & & & & & & $x$ & $x$ & & & & & & & \\
\hline Frustulia sp. & $x$ & & & & & & & & & & & & & & & & & & & & & & & & & & & & & & & & & & & & & & \\
\hline Gomphoneis olivacea & & & & & & & & & & & & $x$ & < & & & & & & & & & & & & & & & & & & & & $x$ & & & & & & \\
\hline Gomphonema cf. parvulum & & & & & & & & & & & & & & & & & & & & & & $x$ & & & & & & & & & & & & & & & & & \\
\hline Gomphonema gracile & & & $x$ & & & & & & & & & & $x$ & & & & & & & & & $x$ & $x$ & & & & $x$ & & $x$ & $\mathrm{x}$ & & & $x$ & $x$ & & & & & \\
\hline Gomphonema sp. & & & & & & & & & & & $x$ & & & & & & & & & $x$ & $x$ & $x$ & & & & & & & & & $x$ & & & & & & & & \\
\hline Gomphonema truncatum & & & & & & & & & & & & & & & & & & & & $x$ & $x$ & & & & & & & & & & & & & & & & & & \\
\hline
\end{tabular}


Table 10. Phytoplankton taxa collected in Topock Marsh at each sample station on each sampling date.-Continued

[TP, sampling station, O1, October 2011; F², February 2012; M, March 2012; Jn, June 2013; Jl, July 2013; O³, October 2013; F, February 2014; A, April 2014; O4, October 2014; A

\begin{tabular}{|c|c|c|c|c|c|c|c|c|c|c|c|c|c|c|c|c|c|c|c|c|c|c|c|c|c|c|c|c|c|c|c|c|c|c|c|c|c|c|c|c|c|}
\hline \multirow{3}{*}{$\begin{array}{c}\text { Taxonomy } \\
\text { Phylum } \\
\text { Genus species } \\
\end{array}$} & \multicolumn{9}{|c|}{ TP-3 } & \multicolumn{10}{|c|}{ TP-2 } & \multicolumn{12}{|c|}{ TP-6 } & \multicolumn{10}{|c|}{ TP-8 } \\
\hline & \multirow{2}{*}{$\begin{array}{c}2011 \\
0^{1} \\
\end{array}$} & \multirow{2}{*}{\multicolumn{2}{|c|}{$\begin{array}{c}2012 \\
F^{2} \quad M\end{array}$}} & \multicolumn{3}{|c|}{2013} & \multicolumn{3}{|c|}{2014} & 20 & & 201 & & & 0013 & & & 201 & & & 11 & 20 & 12 & & 013 & & & & 201 & & & 201 & & 201 & & & 013 & & & 201 & \\
\hline & & & & Jn & Jl & $0^{3}$ & $F^{4}$ & A & $0^{4}$ & $\mathbf{A}^{1}$ & $\mathbf{0}^{1}$ & & $\mathbf{M}$ & Jn & 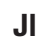 & $0^{3}$ & $F^{4}$ & A & $0^{4}$ & & $0^{1}$ & & $\mathbf{M}$ & Jn & 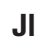 & $0^{3}$ & $\mathbf{F}$ & $=4$ & A & $0^{4}$ & & $A^{1}$ & $\mathbf{0}^{1}$ & & $\mathbf{M}$ & Jn & Jl & $0^{3}$ & $F^{4}$ & A & $0^{4}$ \\
\hline Gyrosigma sp. & $x$ & & & & & $x$ & $x$ & $x$ & $x$ & & & & & $x$ & & & $x$ & & & $\mathrm{X}$ & & & & & & & $x$ & $x>$ & $x$ & $x$ & $\mathrm{x}$ & & & & & $x$ & & & & $x$ & $x$ \\
\hline Gyrosigma spencerii & & & & & & & & & & & & & & & & & & & & & & & $\mathrm{x}$ & & & & & & & & & & & & & & & & & & \\
\hline Hippodonta capitata & & & $\mathrm{x}$ & & & & & & & & & $\mathrm{x}$ & & & & & & & & & & & & & & & & & & & & & & $\mathrm{x}$ & & & & & & & \\
\hline Mastogloia smithii & & & $\mathrm{x}$ & & & & $x$ & & $x$ & & & $x$ & $x$ & & & $x$ & & & $x$ & & & $\mathrm{x}$ & $x$ & & $\mathrm{x}$ & $x$ & $x$ & $x$ & & & $x$ & & & $x$ & & $x$ & & & $x$ & & $x$ \\
\hline Mastogloia sp. & & & & & & & & & & & & & & & & & & & & & & & & & & & & & & & & & & & $x$ & & & & & & \\
\hline Navicula capitatoradiata & & $x$ & & & & & & & & & & & $\mathrm{x}$ & & & & & & & & & & & & $x$ & & & & & & & & & & & & & & & & \\
\hline Navicula cryptocephala & & & $\mathrm{x}$ & & & & & & & & & & & & & & & & & & & $\mathrm{x}$ & & & & & & & & & & & & & & & & & & & \\
\hline Navicula cryptotenella & & & $\mathrm{x}$ & & & & $x$ & & & & & $\mathrm{x}$ & & $x$ & & & $x$ & $x$ & & & & & $\mathrm{x}$ & $x$ & & & & & & & $\mathrm{x}$ & & & & & $x$ & & & & $x$ & \\
\hline Navicula gregaria & & & $\mathrm{x}$ & & & & $x$ & & & & & & & & & & & & & & & $\mathrm{x}$ & $\mathrm{x}$ & & & & $x$ & $x>$ & $x$ & & & & & & & & & & & & \\
\hline Navicula lancolata & & & & & & $x$ & & & & & & & & & $\mathrm{x}$ & & & & & & & & & & & & & & & & & & & & & & & & $x$ & & \\
\hline Navicula radiosa & & & & & & & & & & & & & $x$ & & & & & & & & & & & & & & & & & & & & & & & & & & & & \\
\hline Navicula recens & & & & & & & & & & & & & & & & & & & & & & & & & & & & & & & & & & $\mathrm{x}$ & & & & & & & \\
\hline Navicula $\mathrm{sp}$. & & $x$ & $\mathrm{x}$ & $x$ & $x$ & & & & & $\mathrm{x}$ & $x$ & $x$ & & $x$ & $\mathrm{x}$ & & & & & $\mathrm{X}$ & $\mathrm{x}$ & $\mathrm{x}$ & $x$ & $x$ & $\mathrm{x}$ & & & & & & & $\mathrm{x}$ & $x$ & $x$ & $x$ & & $x$ & & & & \\
\hline Navicula trivialis & & & & & & & & & & & & & & & & & & & & & & & & & & & $x$ & $x$ & & & & & & $\mathrm{x}$ & & & & & & & \\
\hline Navicula veneta & & & & $x$ & & & $x$ & & & & & & & & $x$ & & $x$ & & & & & & & & & & $x$ & $x$ & & & & & & & & & & & & & \\
\hline Navicula viridis & & & & & & & & & & & & & & & & & & & & & & & & & & & & & & & & & & & $\mathrm{x}$ & & & & & & \\
\hline Neidium sp. & & & & & & & & & & $\mathrm{x}$ & & & & & & & & & & $x$ & & & & & & & & & & & & $\mathrm{x}$ & & & & & & & & & \\
\hline Nitzschia acicularis & $X$ & $X$ & $\mathrm{X}$ & $X$ & $\mathrm{X}$ & $\mathrm{X}$ & $X$ & $\mathrm{X}$ & & & & & $\mathrm{X}$ & & & & $X$ & & & & & $\mathrm{X}$ & & & & $\mathrm{X}$ & & & & & & & & $X$ & $\mathrm{X}$ & $X$ & $X$ & $X$ & & & $\mathrm{X}$ \\
\hline Nitzschia agnita & & $\mathrm{X}$ & & & & & & & & & & & & & & & & & & & & & & & & & & & & & & & & & & & & & & & \\
\hline Nitzschia amphibia & & & $\mathrm{X}$ & $\mathrm{X}$ & & $\mathrm{X}$ & $\mathrm{X}$ & & & & & $\mathrm{X}$ & & & & $\mathrm{X}$ & & $\mathrm{X}$ & & & & $\mathrm{X}$ & $\mathrm{X}$ & $X$ & $\mathrm{x}$ & & $\underline{x}$ & K & & & & & & $\mathrm{X}$ & & & & & $\mathrm{X}$ & $\mathrm{X}$ & \\
\hline Nitzschia angustata & & & $\mathrm{X}$ & & & & & & & & & & & & & & & & & & & $\mathrm{X}$ & & & & & & & & & & & & & & & & & & & \\
\hline Nitzschia bryophila & & & $\mathrm{X}$ & & & & & & & & & & & & & & & & & & & & & & & & & & & & & & & & & & & & & & \\
\hline Nitzschia capitellata & & $x$ & & & & & & & & & & & & & & & & & & & & & & & & & & & & & & & & & & & & & & & \\
\hline Nitzschia cf. commutatoides & & $\mathrm{X}$ & & & & & & & & & & & & & & & & & & & & & & & & & & & & & & & & & & & & & & & \\
\hline Nitzschia constricta & & & & & & & $X$ & & $\mathrm{X}$ & & & & & & & & & $\mathrm{X}$ & & & & & & & & & $x$ & $\gamma$ & $x$ & & & & & & & & & & $X$ & & \\
\hline Nitzschia cf. flexoides & & & & & & & & & & & & & & & & & & & & & & & $\mathrm{X}$ & & & & & & & & & & & & & & & & & & \\
\hline Nitzschia cf. gracilis & & & & & & & & & & & & $x$ & & & & & & & & & & & & & & & & & & & & & & & & & & & & & \\
\hline Nitzschia cf. parvula & & & & & & & & & & & & & & & & & & & & & & $\mathrm{X}$ & & & & & & & & & & & & & & & & & & & \\
\hline Nitzschia denticula & & & & & & & & & & & & $\mathrm{X}$ & & & & & & & & & & & $\mathrm{X}$ & & & & & & & & & & & & & & & & & & \\
\hline Nitzschia dissipata & & $\mathrm{X}$ & $\mathrm{X}$ & & & & & & & & & & & & & & & & & & & & & & & & & & & & & & & & & & & & & & \\
\hline Nitzschia gracilis & & & & & & & & & & & & & $\mathrm{X}$ & & & & & & & & & & & & & & & & & & & & & & & & & & & & \\
\hline Nitzschia inconspicua & & & $\mathrm{X}$ & $\mathrm{X}$ & $\mathrm{X}$ & $\mathrm{X}$ & $\mathrm{X}$ & $\mathrm{X}$ & $\mathrm{X}$ & & & & & $\mathrm{X}$ & $\mathrm{X}$ & $\mathrm{x}$ & $X$ & & $\mathrm{X}$ & & & & & $X$ & $\mathrm{x}$ & $\mathrm{X}$ & & & $x$ & & & & & & & $\mathrm{X}$ & $\mathrm{X}$ & $X$ & $X$ & $X$ & $\mathrm{X}$ \\
\hline Nitzschia intermedia & & & & & & & & & & & & & & & & & & & & & & $\mathrm{X}$ & & & & & & & & & & & & $\mathrm{X}$ & & & & & & & \\
\hline Nitzschia levidensis & & & & $\mathrm{X}$ & $\mathrm{X}$ & & & & & & & & & & & & & $\mathrm{X}$ & & & & & & & & & & & & & & & & & & & & & & $X$ & \\
\hline Nitzschia linearis & & & $\mathrm{X}$ & & & & & & & & & & & & & & & & & & & $\mathrm{X}$ & & & & & & & & & & & & & & & & & & & \\
\hline Nitzschia microcephala & & & & & & & & & & & & $\mathrm{X}$ & & & & & & & & & & & & & & & & & & & & & & & & & & & & & \\
\hline
\end{tabular}


Table 10. Phytoplankton taxa collected in Topock Marsh at each sample station on each sampling date.-Continued

[TP, sampling station, O1', October 2011; F², February 2012; M, March 2012; Jn, June 2013; J1, July 2013; O³, October 2013; F, February 2014; A, April 2014; O4, October 2014; A , August 2011]

\begin{tabular}{|c|c|c|c|c|c|c|c|c|c|c|c|c|c|c|c|c|c|c|c|c|c|c|c|c|c|c|c|c|c|c|c|c|c|c|c|c|c|c|c|c|c|c|}
\hline \multirow{3}{*}{$\begin{array}{c}\text { Taxonomy } \\
\text { Phylum } \\
\text { Genus species }\end{array}$} & \multicolumn{9}{|c|}{ TP-3 } & \multicolumn{9}{|c|}{ TP-2 } & \multicolumn{12}{|c|}{ TP-6 } & \multicolumn{12}{|c|}{ TP-8 } \\
\hline & \multirow{2}{*}{$\begin{array}{c}2011 \\
0^{1}\end{array}$} & \multicolumn{2}{|c|}{2012} & \multicolumn{3}{|c|}{2013} & \multicolumn{3}{|c|}{2014} & 2011 & 20 & & & 2013 & & & 2014 & & 20 & & 20 & & & 201 & & & & 20 & 14 & & & 201 & & 201 & & & 2013 & & & 20 & 14 & \\
\hline & & & & Jn & Jl & $0^{3}$ & $F^{4}$ & A & $0^{4}$ & $A^{1} 0^{1}$ & $\mathbf{F}^{2}$ & $\mathbf{M}$ & Jn & Jl & $0^{3}$ & $F^{4}$ & A & $0^{4}$ & $A^{1}$ & $\mathbf{0}^{1}$ & $\mathbf{F}^{2}$ & M & Jn & J & & $0^{3}$ & $F^{4}$ & A & & 4 * & & $A^{1} C$ & & & $\mathbf{M}$ & Jn & Jl & $0^{3}$ & $F$ & 4 & $A$ & $0^{4}$ \\
\hline Nitzschia palea & $X$ & $X$ & $X$ & $X$ & & $X$ & $X$ & $X$ & $X$ & & $\mathrm{X}$ & $X$ & $X$ & & $X$ & $X$ & & & & & $\mathrm{X}$ & $x$ & $\mathrm{X}$ & $\mathrm{X}$ & & & & $X$ & & & & & & $X$ & $X$ & $X$ & & $X$ & $x$ & $\gamma$ & $x$ & \\
\hline Nitzschia perminuta & & & & $x$ & & $X$ & & $X$ & $X$ & & $\mathrm{X}$ & & $X$ & & $X$ & & & & & & & & $x$ & & $\gamma$ & $x$ & & $X$ & $\mathrm{X}$ & $\mathrm{X}$ & & & & & & $X$ & & $X$ & & & & \\
\hline Nitzschia pura & & & $X$ & & & & & & & & & & & & & & & & & & & & & & & & & & & & & & & & & & & & & & & \\
\hline Nitzschia reversa & & & & & & & & & & & & & & & & & & & & & $\mathrm{X}$ & & & & & & & & & & & & & & & & & & & & & \\
\hline Nitzschia scalaris & & & & & & & & & & & & $X$ & & & & & & & & & $x$ & & & & & & & & & & & & & & & & & & & & & \\
\hline Nitzschia sigma & & & & & & & & & & & & $X$ & & & & & & & & & & & & & & & & & & & & & & & & & & & & & & \\
\hline Nitzschia sp. & $\mathrm{X}$ & & $X$ & & & $X$ & & & & & & $X$ & & & & & & & $\mathrm{X}$ & & $\mathrm{X}$ & $\mathrm{X}$ & $X$ & & & & & & & $\mathrm{X}$ & & $X$ & & & $x$ & & & & & & & \\
\hline Nitzschia subacicularis & & & $X$ & & & & & & & & $\mathrm{X}$ & & & & & & & & & & $\mathrm{X}$ & & & & & & & & & & & & & & & & & & & & & \\
\hline cf. Pinnularia sp. & & & & & & & & & & & & & & & & & & & & & & $\mathrm{X}$ & & & & & & & & & & & & & & & & & & & & \\
\hline Pinnularia sp. & & & & & & & & & & & & & & & & & & & $\mathrm{X}$ & $\mathrm{X}$ & & & & & & & & & & & & & & & & & & & & & & \\
\hline Planothidium lanceolata & & & & & & & & & & & & & & & & & & & $\mathrm{X}$ & & & & & & & & & & & & & & & & & & & & & & & \\
\hline Pleurosigma elongatum & & $\mathrm{X}$ & & & & & & & & & & & & & & & & & & & & & & & & & & & & & & & & & $\mathrm{X}$ & & & & & & & \\
\hline Pleurosigma salinarum & & & $X$ & & & & & & & & & & & & & & & & & & $\mathrm{X}$ & $\mathrm{X}$ & & & & & & & & & & & & $\mathrm{X}$ & & & & & & & & \\
\hline Pleurosigma sp. & & & & & & & & & & & & $X$ & & & & & & & & & & & & & & & & & & & & & & & & & & & & & & \\
\hline Pseudostaurosira brevistriata & & & $X$ & $X$ & & & $X$ & $X$ & $X$ & & $\mathrm{X}$ & $X$ & & & & $x$ & $X$ & & & & $x$ & $\mathrm{X}$ & $X$ & & & & $x$ & & & & & & & $X$ & $x$ & & $\mathrm{x}$ & & & $\gamma$ & $x$ & \\
\hline $\begin{array}{l}\text { Pseudostaurosira brevistriata } \\
\quad \text { var. trigibba }\end{array}$ & & $x$ & $X$ & & & & & & & & $\mathrm{x}$ & $X$ & & & & & & & & & $x$ & $x$ & & & & & & & & & & & & $X$ & $x$ & & & & & & & \\
\hline Puncticulata bodanica & & & & & & & & & & & & $X$ & & & & & & & & & & & & & & & & & & & & & & & & & & & & & & \\
\hline Reimeria sinuata & & & & & & & & & & & & & & & & & $x$ & & & & & & & & & & & & & & & & & & & & & & & & & \\
\hline Rhoicosphenia abbreviata & & & & & & & & & & & $\mathrm{X}$ & & & & & & & & & & & & & & & & & & & & & & & & & & & & & & & \\
\hline Rhopalodia gibba & & & & & $\mathrm{X}$ & $X$ & $X$ & & $X$ & $\mathrm{X}$ & & $X$ & & & & & & $x$ & $\mathrm{X}$ & & $\mathrm{X}$ & $\mathrm{X}$ & $\mathrm{X}$ & $\mathrm{X}$ & & & $\mathrm{X}$ & & $\mathrm{X}$ & $x$ & & $\mathrm{X}$ & & & & & & & & & & $x$ \\
\hline Sellaphora laevissima & & & & & & & & & & & & $X$ & & & & & & & & & & & & & & & & & & & & & & & & & & & & & & \\
\hline Sellaphora pupula & & & & & & & & & & & & & & & & & & & & & & & & & & & & & & & & & & $X$ & & & & & & & & \\
\hline Sellaphora sp. & & & & & & & & & & & & & & & & & & & & & $\mathrm{X}$ & & & & & & & & & & & & & & & & & & & & & \\
\hline Stauroneis sp. & & & & & & & & & & & & & & & & & & & $\mathrm{X}$ & & & & & & & & & & & & & $X$ & & & & & & & & & & \\
\hline Staurosira construens & & & $X$ & $X$ & & & & $X$ & $X$ & & & & $\mathrm{X}$ & & & & & $x$ & & & $\mathrm{X}$ & $\mathrm{X}$ & $X$ & $\mathrm{X}$ & 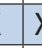 & $\mathrm{x}$ & $x$ & $\mathrm{X}$ & & $x$ & & & & & & $X$ & $\mathrm{X}$ & $X$ & $x$ & & & $x$ \\
\hline Staurosira elliptica & & & $X$ & & & & & & & & & & & & & & & & & & & & & & & & & & & & & & & & & & & & & & & \\
\hline Staurosirella lapponica & & $X$ & $X$ & & & & & & & & $\mathrm{X}$ & $X$ & & & & & & & & & $\mathrm{X}$ & $x$ & & & & & & & & & & & & & $\mathrm{X}$ & & & & & & & \\
\hline Staurosirella pinnata & & & & $X$ & $\mathrm{X}$ & $X$ & $X$ & $\mathrm{X}$ & $X$ & & & & $X$ & & $X$ & $X$ & & & & & $\mathrm{X}$ & $\mathrm{X}$ & $X$ & $\mathrm{X}$ & $\gamma$ & $\mathrm{X}$ & $X$ & $\mathrm{X}$ & $\mathrm{X}$ & $x$ & & & & & & $\mathrm{X}$ & $\mathrm{X}$ & $X$ & $\mathrm{X}$ & 7 & $x$ & $x$ \\
\hline Stephanocyclus meneghiniana & & & $X$ & $X$ & $\mathrm{X}$ & & & $X$ & $X$ & & & $X$ & $\mathrm{X}$ & $\mathrm{X}$ & $\mathrm{X}$ & $\mathrm{X}$ & $X$ & & & & $\mathrm{X}$ & $\mathrm{X}$ & & & & $\mathrm{X}$ & $X$ & & $\mathrm{X}$ & $\mathrm{X}$ & & & & & & $X$ & $\mathrm{X}$ & $X$ & $X$ & 7 & $x$ & \\
\hline Stephanodiscus niagarae & & & & $X$ & & & & & & & & & & & & & & & & & & & & & & & & & & & & & & & & & & $X$ & & & & \\
\hline Stephanodiscus parvus & & & & $X$ & $X$ & & & & $X$ & & & & $X$ & $X$ & & $x$ & $X$ & $x$ & & & & & $X$ & $x$ & $\gamma$ & $x$ & $X$ & & & & & & & & & $X$ & $\mathrm{x}$ & $X$ & $x$ & & & $x$ \\
\hline Stephanodiscus sp. & & & & & & & & & & & $X$ & & & & & & & & & & $\mathrm{X}$ & & & & & & & & & & & 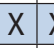 & $\mathrm{X}$ & $X$ & & & & & & & & \\
\hline Surirella angusta & & & & & & & & & & & & & & & & & & & & & & $\mathrm{X}$ & & & & & & & & & & & & & & & & & & & & \\
\hline Surirella brebissonii & & $\mathrm{X}$ & & & & & & & & & & & & & & & & & & & & $\mathrm{X}$ & & & & & & & & & & & & & & & & & & & & \\
\hline Surirella minuta & & & & & & & & & & & & $X$ & & & & & & & & & & & & & & & & & & & & & & & & & & & & & & \\
\hline
\end{tabular}


Table 10. Phytoplankton taxa collected in Topock Marsh at each sample station on each sampling date.-Continued

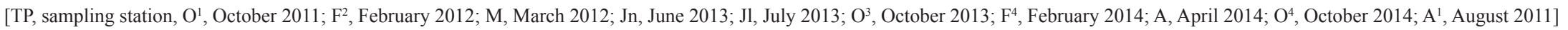

\begin{tabular}{|c|c|c|c|c|c|c|c|c|c|c|c|c|c|c|c|c|c|c|c|c|c|c|c|c|c|c|c|c|c|c|c|c|c|c|c|c|c|c|c|}
\hline \multirow{3}{*}{$\begin{array}{c}\text { Taxonomy } \\
\text { Phylum } \\
\text { Genus species } \\
\end{array}$} & \multicolumn{9}{|c|}{ TP-3 } & \multicolumn{10}{|c|}{ TP-2 } & \multicolumn{10}{|c|}{ TP-6 } & \multicolumn{10}{|c|}{ TP-8 } \\
\hline & \multirow{2}{*}{$\begin{array}{c}2011 \\
0^{1}\end{array}$} & \multirow{2}{*}{\multicolumn{2}{|c|}{$\begin{array}{cc}2012 \\
F^{2} & M\end{array}$}} & \multicolumn{3}{|c|}{2013} & \multicolumn{3}{|c|}{2014} & \multirow{2}{*}{\multicolumn{2}{|c|}{$\begin{array}{c}2011 \\
A^{1} \\
0^{1}\end{array}$}} & \multirow{2}{*}{\multicolumn{2}{|c|}{$\begin{array}{ll}2012 \\
F^{2} & M\end{array}$}} & \multicolumn{3}{|c|}{2013} & \multicolumn{3}{|c|}{2014} & \multirow{2}{*}{\multicolumn{2}{|c|}{$\begin{array}{ll}2011 \\
A^{1} & 0^{1}\end{array}$}} & \multicolumn{2}{|c|}{2012} & \multicolumn{3}{|c|}{2013} & \multicolumn{3}{|c|}{2014} & \multirow{2}{*}{\multicolumn{2}{|c|}{$\left|\begin{array}{cc}2011 \\
A^{1} & 0^{1}\end{array}\right|$}} & \multirow{2}{*}{\multicolumn{2}{|c|}{$\begin{array}{ll}2012 \\
F^{2} & M\end{array}$}} & \multicolumn{3}{|c|}{2013} & \multicolumn{3}{|c|}{2014} \\
\hline & & & & Jn & Jl & $0^{3}$ & $F^{4}$ & A & $0^{4}$ & & & & & Jn & Jl & $0^{3}$ & $F^{4}$ & A & $0^{4}$ & & & $F^{2}$ & & Jn & Jl & $0^{3} \mathrm{~F}$ & $F^{4}$ & A & $\mathbf{0}^{4 *}$ & & & & & Jn & ال & $0^{3}$ & & A & $0^{4}$ \\
\hline Surirella ovata & & & & & & & & & & $\mathrm{X}$ & & & & & & & & & & $\mathrm{X}$ & & & & & & & & & & & & & & & & & & & \\
\hline Surirella sp. & & & & & & & & & & & & & & & & & & & & $X$ & $\mathrm{X}$ & $x$ & & & & & & & & & & & & & & & & & \\
\hline Synedra delicatissima & & $x$ & $x$ & & & & & & & & & $\mathrm{X}$ & $x$ & & & & & & & $X$ & & $x$ & $x$ & & & & & & & & & $x$ & & & & & & & \\
\hline Synedra spp. & $x$ & & & & & & & & & $X$ & $\mathrm{X}$ & $\mathrm{X}$ & & & & & & & & $X$ & & & & & & & & & & $\mathrm{X}$ & $x$ & & & & & & & & \\
\hline Synedra tenera & & & $X$ & & $x$ & $\mathrm{X}$ & $\mathrm{X}$ & $x$ & $X$ & & & $\mathrm{X}$ & & $X$ & $X$ & $\mathrm{X}$ & $\mathrm{X}$ & & $x$ & & & $X$ & & $\mathrm{X}$ & $X$ & & $\mathrm{X}$ & $X$ & & & & $\mathrm{X}$ & $\mathrm{X}$ & $\mathrm{X}$ & $\mathrm{X}$ & $\mathrm{X}$ & $\mathrm{X}$ & $x$ & $x$ \\
\hline Synedra ulna & & & $X$ & $x$ & & $\mathrm{X}$ & $\mathrm{X}$ & $\mathrm{X}$ & & & & $\mathrm{X}$ & & $\mathrm{X}$ & $X$ & $\mathrm{X}$ & & \begin{tabular}{|l|l|l}
$x$ & $\gamma$ \\
\end{tabular} & $X$ & & & & $X$ & $\mathrm{X}$ & $\mathrm{X}$ & & $\mathrm{X}$ & \begin{tabular}{l|l}
$x$ & $x$ \\
\end{tabular} & $\mathrm{X} X$ & & & $X$ & & $\mathrm{X}$ & $\mathrm{X}$ & & & $\mathrm{X}$ & $X$ \\
\hline Tryblionella apiculata & & & & $\mathrm{X}$ & & & & & & & & & & & & & & & & & & & & $\mathrm{X}$ & & & & & & & & & & & & & & & \\
\hline Tryblionella constricta & & & $X$ & & & & & & & & & & & & & & & & & & & & $X$ & & & & & & & & & $X$ & & & & & & & \\
\hline Tryblionella levidensis & & & & & & & & & & & & & & & & & & & & & & $x$ & & & & & & & & & & & & & & & & & \\
\hline
\end{tabular}

CHLOROPHYTA (green algae)

Botryococcus braunii

Bulbochaete sp.

Characium ambiguum

cf. Chlamydomonas sp.

Chlamydomonas sp.

Chlorella sp.

Coelastrum microporum

Cosmarium sp.

Crucigenia quadrata

Crucigenia tetrapedia

Dictyosphaerium pulchellum

Eudorina elegans

Kirchneriella contorta

Lagerheimia genevensis

Lobomonas sp.

Monoraphidium minutum

Oedogonium sp.

Oocystis parva

Oocystis sp.

Pediastrum duplex

Pyramimonas tetrarhynchus

Raphidocelis contorta

Scenedesmus acuminatus

Scenedesmus bijuga
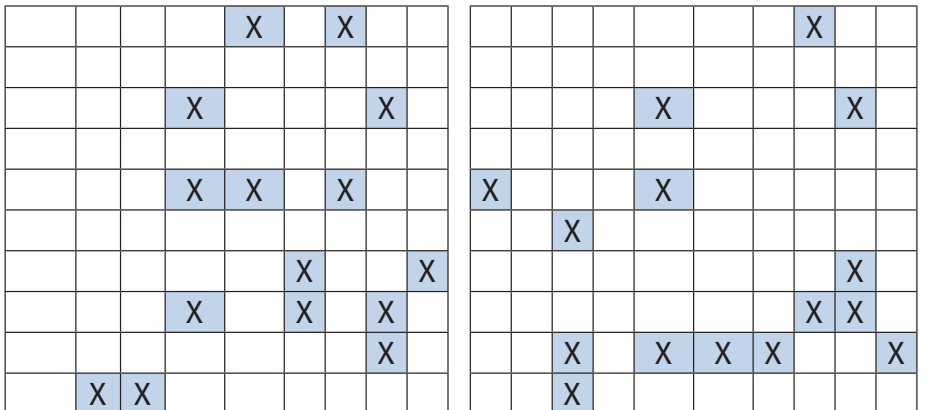

$\mathrm{X} X$
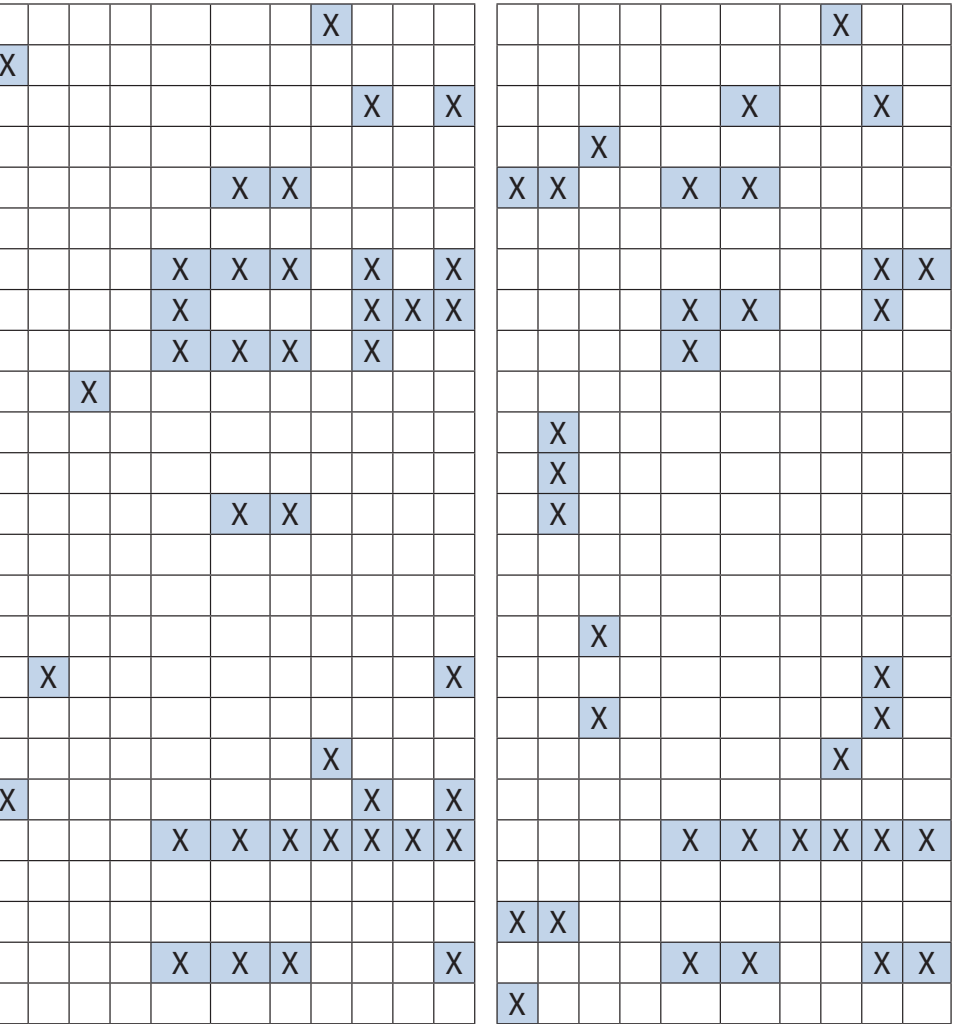

\begin{tabular}{|c|c|c|c|c|c|c|c|}
\hline & & $X$ & $X$ & & & $X$ & \\
\hline & & & & & & & \\
\hline & & & & & & & \\
\hline \multicolumn{8}{|c|}{$X$} \\
\hline & & & & & & $X$ & \\
\hline & & & & & & & \\
\hline & & & & & & & \\
\hline & & $X$ & $X$ & $X$ & $X$ & $x$ & $X$ \\
\hline & & & & & & & \\
\hline & & & & & & & \\
\hline & & $X$ & $X$ & & & $X$ & \\
\hline & & & & & & & \\
\hline
\end{tabular}

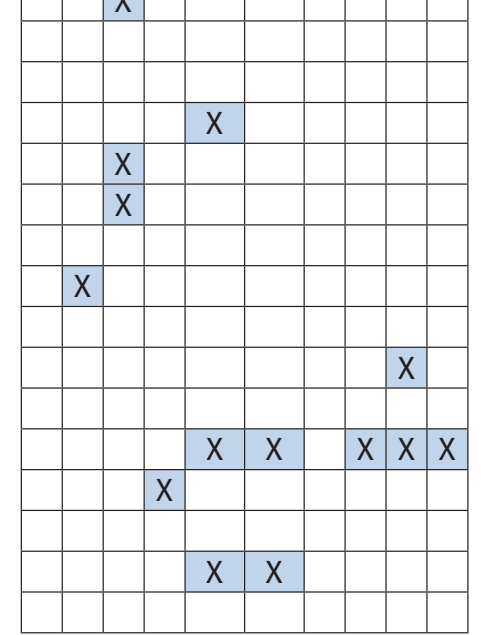

Scenedesmus brasiliensis 
Table 10. Phytoplankton taxa collected in Topock Marsh at each sample station on each sampling date.-Continued

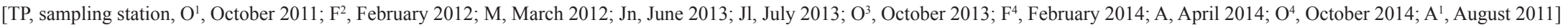

\begin{tabular}{|c|c|c|c|c|c|c|c|c|c|c|c|c|c|c|c|c|c|c|c|c|c|c|c|c|c|c|c|c|c|c|c|c|c|c|c|c|c|c|}
\hline \multirow{3}{*}{$\begin{array}{c}\text { Taxonomy } \\
\text { Phylum } \\
\text { Genus species }\end{array}$} & \multicolumn{9}{|c|}{ TP-3 } & \multicolumn{9}{|c|}{ TP-2 } & \multicolumn{9}{|c|}{ TP-6 } & \multicolumn{11}{|c|}{ TP-8 } \\
\hline & \multirow{2}{*}{$\begin{array}{c}2011 \\
0^{1}\end{array}$} & \multirow{2}{*}{\multicolumn{2}{|c|}{$\begin{array}{cc}2012 \\
F^{2} & M\end{array} \mid$}} & \multicolumn{3}{|c|}{2013} & \multicolumn{3}{|c|}{2014} & \multirow{2}{*}{$\begin{array}{ll}2011 \\
A^{1} & 0^{1}\end{array}$} & \multirow{2}{*}{\multicolumn{2}{|c|}{$\begin{array}{ll}2012 \\
F^{2} & M\end{array}$}} & \multicolumn{3}{|c|}{2013} & \multicolumn{3}{|c|}{2014} & \multirow{2}{*}{$\begin{array}{cc}2011 \\
A^{1} & 0^{1}\end{array}$} & \multirow{2}{*}{$\begin{array}{l}2012 \\
F^{2} \quad M\end{array}$} & \multicolumn{3}{|c|}{2013} & \multicolumn{4}{|c|}{2014} & \multirow{2}{*}{\multicolumn{2}{|c|}{$\begin{array}{cc}2011 \\
A^{1} & 0^{1}\end{array} \mid$}} & \multirow{2}{*}{\multicolumn{2}{|c|}{$\begin{array}{ll}2012 \\
F^{2} & M\end{array}$}} & \multicolumn{3}{|c|}{2013} & & & 014 & \\
\hline & & & & Jn & Jl & $0^{3}$ & $F^{4}$ & A & $0^{4}$ & & & & Jn & Jl & $0^{3}$ & $F^{4}$ & A & $0^{4}$ & & & Jn & Jl & $0^{3}$ & $\mathbf{F}^{4}$ & A & 0 & $4 *$ & & & & & Jn & J & $0^{3}$ & $F^{4}$ & $A$ & A O & $0^{4}$ \\
\hline Scenedesmus communis & & & & $X$ & & & & & & & & & $\mathrm{X}$ & & & & & & & & $\mathrm{X}$ & & & & & & & & & & & $X$ & & & & & & \\
\hline Scenedesmus dimorphus & & & & & & $\mathrm{X}$ & & & & & & & $\mathrm{X}$ & & & & & $\mathrm{X}$ & & & & $\mathrm{X}$ & & & $X$ & & & & & & & $\mathrm{X}$ & $\mathrm{X}$ & & & & & $\mathrm{X}$ \\
\hline Scenedesmus intermedius & & & & & & & & & & & $\mathrm{X}$ & & & & & & & & & & & & & & & & & & & & & & & & & & & \\
\hline $\begin{array}{l}\text { Scenedesmus opoliensis var. } \\
\quad \text { mononensis }\end{array}$ & & & r & & & & & & & & & & & & & & & & & & & & & & & & & & & $X$ & & & & & & & & \\
\hline Scenedesmus quadricauda & & & & & & & & $\mathrm{X}$ & $X$ & & & & & $\mathrm{X}$ & $\mathrm{X}$ & $\mathrm{X}$ & $\mathrm{X}$ & $X$ & $x$ & & & $x$ & $\mathrm{X}$ & $X$ & $X$ & $X$ & $\mathrm{X}$ & $X$ & $\mathrm{X}$ & & & & $x$ & $x$ & $X$ & $x$ & $x>$ & $X$ \\
\hline Scenedesmus sp. & & & & & & & & & & & & & & & & & & & $x$ & & & & & & & & & $X$ & $\mathrm{X}$ & & $X$ & & & & & & & \\
\hline Scenedesmus subspicatus & & & K & & & & & & & & & & & & & & & & & & & & & & & & & & & $\mathrm{X}$ & & & & & & & & \\
\hline Selenastrum gracile & & & & & & & & & & & & & & & & & & & & & & $\mathrm{X}$ & & & & & $\mathrm{X}$ & & & & & & & & & & & \\
\hline Selenastrum minutum & & & & & & & & & & & & & & & & & & & & & & & & & & & & & $\mathrm{X}$ & & & & & & & & & \\
\hline Sphaerocystis schroeteri & & & & & & & & $X$ & & & & & $\mathrm{X}$ & $X$ & & & & $X$ & & & & $\mathrm{X}$ & & & & & $\mathrm{X}$ & & & & & $X$ & $\mathrm{X}$ & & $X$ & $x$ & $X$ & $X$ \\
\hline Sphaerocystis sp. & & & & & & & & & & & & & & & & & & & & & & & & & & & & & & & $x$ & & & & & & & \\
\hline Staurastrum spp. & & & & $x$ & & & & & $x$ & & & & & $X$ & & & & $X$ & & & & $\mathrm{X}$ & & & & & $\mathrm{x}$ & & $\mathrm{X}$ & & & & $\mathrm{X}$ & & & & & \\
\hline Tetraedron caudatum & & & & & & & & $\mathrm{X}$ & & & & & & & & & $\mathrm{X}$ & & & & & $\mathrm{X}$ & & & & & $\mathrm{X}$ & & & $\mathrm{X}$ & & $\mathrm{X}$ & $\mathrm{X}$ & & & & & \\
\hline Tetraedron gracile & & & & & $\mathrm{X}$ & & & & & & & & & & & & & & & & & & & & & & & & & & & & $\mathrm{X}$ & & & & & \\
\hline Tetraedron limneticum & & & & & & & & & & $\mathrm{X}$ & & & & & & & & & & & & & & & & & & & & & & & & & & & & \\
\hline Tetraedron minimum & & & & $X$ & & & & $X$ & & & $\mathrm{X}$ & & & $X$ & $\mathrm{x}$ & & $x$ & $X$ & & & $\mathrm{X}$ & $\mathrm{X}$ & $x$ & & $X$ & & $\mathrm{X}$ & & & & & & & & & & & \\
\hline
\end{tabular}

CHRYSOPHYTA (golden algae)

\section{Dinobryon sp.}

Mallomonas pseudocoronata

Mallomonas sp.

Pseudokephyrion pseudospirale

Pseudokephyrion sp.

Synura sp.

\begin{tabular}{|l|l|l|l|l|l|l|l|l|}
\hline $\mathrm{X}$ & & & & & & & & \\
\hline & & & $\mathrm{X}$ & & & & $\mathrm{X}$ & \\
\hline & $\mathrm{X}$ & & & & & & & \\
\hline & $\mathrm{X}$ & $\mathrm{X}$ & & & & & & \\
\hline & $\mathrm{X}$ & & & & & & & \\
\hline & & & & & & & & \\
\hline
\end{tabular}

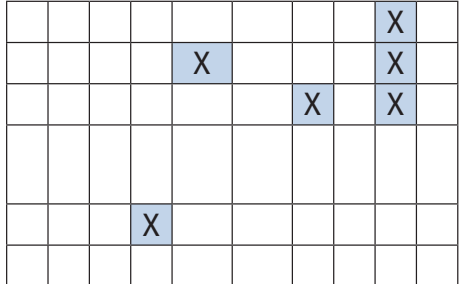

CRYPTOPHYTA (cryptomonads)

Cryptomonas sp.

Rhodomonas minuta var.

nannoplanctica
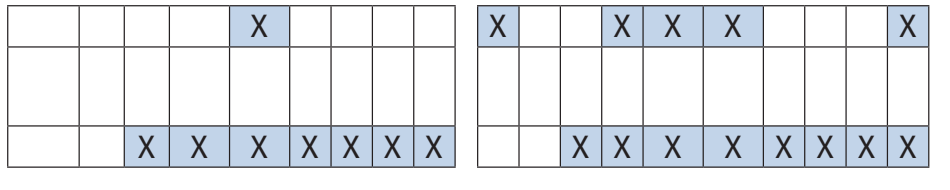

\begin{tabular}{|c|c|c|c|c|c|c|c|c|c|c|}
\hline & $\mathrm{X}$ & & & $\mathrm{X}$ & $\mathrm{X}$ & & & & $\mathrm{X}$ & $\mathrm{X}$ \\
\hline & $\mathrm{X}$ & & & & & & & & & \\
& & & & & & & & & \\
\hline & & $\mathrm{X}$ & & $\mathrm{X}$ & $\mathrm{X}$ & $\mathrm{X}$ & $\mathrm{X}$ & $\mathrm{X}$ & $\mathrm{X}$ & $\mathrm{X}$ \\
\hline
\end{tabular}

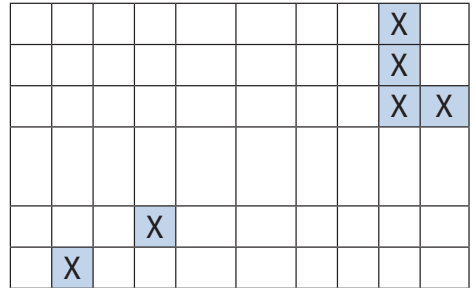

Rhodomonas spp.

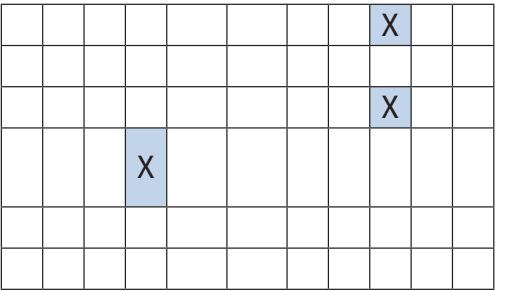

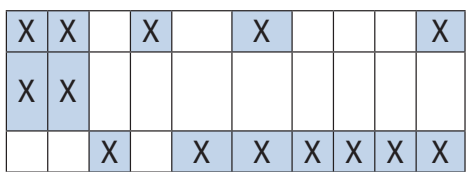


Table 10. Phytoplankton taxa collected in Topock Marsh at each sample station on each sampling date.-Continued

[TP, sampling station, O1, October 2011; F², February 2012; M, March 2012; Jn, June 2013; Jl, July 2013; O³ October 2013; F, February 2014; A, April 2014; O4, October 2014; A², August 2011]

\begin{tabular}{|c|c|c|c|c|c|c|c|c|c|c|c|c|c|c|c|c|c|c|c|c|c|}
\hline \multirow{3}{*}{$\begin{array}{c}\text { Taxonomy } \\
\text { Phylum } \\
\text { Genus species }\end{array}$} & \multicolumn{5}{|c|}{ TP-3 } & \multicolumn{5}{|c|}{ TP-2 } & \multicolumn{6}{|c|}{ TP-6 } & \multicolumn{5}{|c|}{ TP-8 } \\
\hline & 2011 & 2012 & & 2013 & 2014 & 2011 & 2012 & & 013 & 2014 & 2011 & 2012 & & 013 & & 2014 & 2011 & 2012 & & 013 & 2014 \\
\hline & $0^{1}$ & $\mathbf{F}^{2} \quad \mathbf{M}$ & Jn & Jl $\mathbf{0}^{3}$ & $\begin{array}{lll}F^{4} & \text { A } & \mathbf{O}^{4}\end{array}$ & $\begin{array}{ll}A^{1} & \mathbf{0}^{1}\end{array}$ & $F^{2} \quad M$ & Jn & JI $0^{3}$ & $\begin{array}{lll}F^{4} & A & \mathbf{O}^{4}\end{array}$ & $\begin{array}{ll}A^{1} & 0^{1}\end{array}$ & $F^{2} \mathbf{M}$ & Jn & Jl $0^{3}$ & ${ }^{3} \mathbf{F}^{4}$ & $4 \quad$ A $\quad \mathbf{0}^{4 *}$ & $\begin{array}{ll}A^{1} & 0^{1}\end{array}$ & $F^{2} \quad M$ & Jn & JI $0^{3}$ & F $^{4} \quad$ A $\mathbf{O}^{4}$ \\
\hline
\end{tabular}

CYANOPHYTA (blue-green algae)

Anabaena oscillarioides

Anabaena spp.

Anabaenopsis circularis

Anabaenopsis sp.

Aphanizomenon flos-aquae

Calothrix stagnalis

Chroococcus dispersus

Chroococcus minimus

Chroococcus minutus

Chroococcus planctonicus

Chroococcus sp.

Cylindrospermopsis raciborskii

Leptolyngbya $\mathrm{sp}$.

Lyngbya sp.

Merismopedia punctata

Microcystis aeruginosa

Oscillatoria spp.

Oscillatoria tenuis

Planktolyngbya circumcreta

Planktolyngbya contorta

Planktolyngbya limnetica

cf. Planktolyngbya sp.

Planktolyngbya sp.

Pseudanabaena galeata

Pseudanabaena limnetica

Pseudanabaena spp.

Raphidiopsis curvata

Rhabdoderma lineare

Tolypothrix spp.
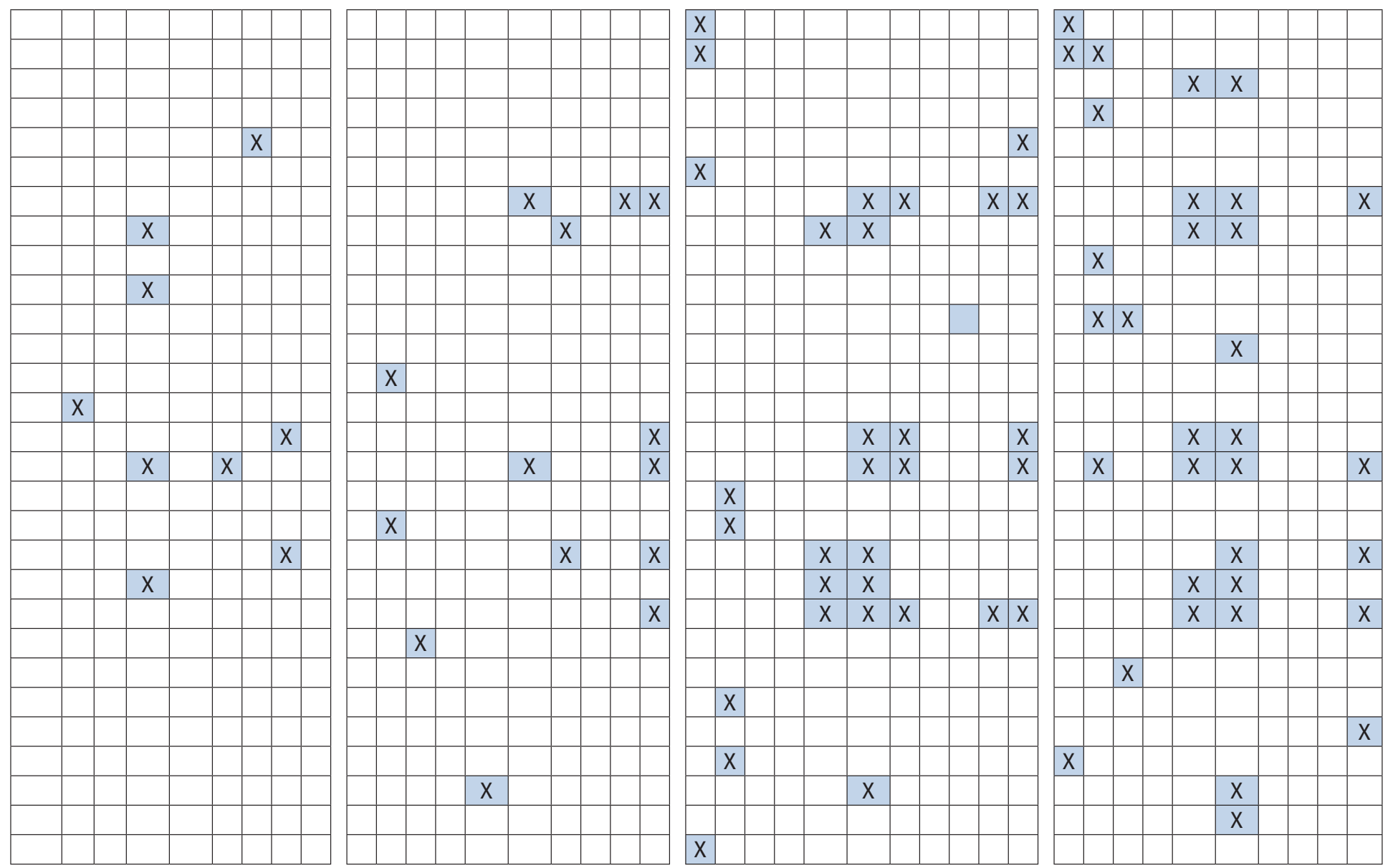
Table 10. Phytoplankton taxa collected in Topock Marsh at each sample station on each sampling date.—Continued

[TP, sampling station, $\mathrm{O}^{1}$, October 2011; F², February 2012; M, March 2012; Jn, June 2013; Jl, July 2013; O², October 2013; F4, February 2014; A, April 2014; O4, October 2014; A ${ }^{1}$, August 2011]

\begin{tabular}{|c|c|c|c|c|c|c|c|c|c|c|c|c|c|c|c|c|c|c|c|c|c|}
\hline \multirow{3}{*}{$\begin{array}{c}\text { Taxonomy } \\
\text { Phylum } \\
\text { Genus species }\end{array}$} & \multicolumn{5}{|c|}{ TP-3 } & \multicolumn{5}{|c|}{ TP-2 } & \multicolumn{6}{|c|}{ TP-6 } & \multicolumn{5}{|c|}{ TP-8 } \\
\hline & 2011 & 2012 & 2013 & & 2014 & 2011 & 2012 & 201 & & 2014 & 2011 & 2012 & 201 & & & 2014 & 2011 & 2012 & 201 & & 2014 \\
\hline & $0^{1}$ & $F^{2} M$ & Jn Jl & $0^{3}$ & $\begin{array}{lll}\mathbf{F}^{4} & \mathbf{A} & \mathbf{0}^{4}\end{array}$ & $\begin{array}{ll}A^{1} & \mathbf{0}^{1}\end{array}$ & $F^{2} M$ & Jn & JI $0^{3}$ & $\begin{array}{llll}F^{4} & A & \mathbf{0}^{4}\end{array}$ & $\begin{array}{ll}A^{1} & 0^{1}\end{array}$ & $F^{2} \mathbf{M}$ & Jn J & $\mid \begin{array}{ll}1 & 0^{3}\end{array}$ & $\mathbf{F}^{4} \quad \mathbf{A}$ & A $0^{4 *}$ & $\begin{array}{ll}A^{1} & 0^{1}\end{array}$ & $F^{2} \mathbf{M}$ & Jn J & $\mid \begin{array}{l}\mid \\
\mid\end{array}$ & $\begin{array}{lll}F^{4} & A & 0^{4}\end{array}$ \\
\hline
\end{tabular}

EUGLENOPHYTA (euglenoids)

\section{Euglena acus}

Euglena sp.

Lepocinclis spyrogyroides

Phacus sp.

Trachelomonas spp.

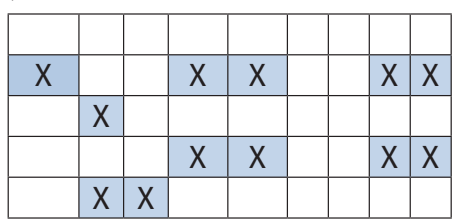

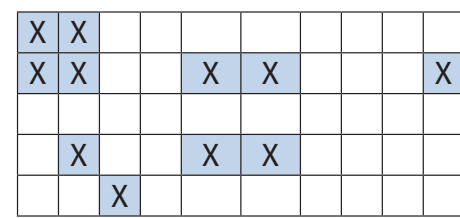
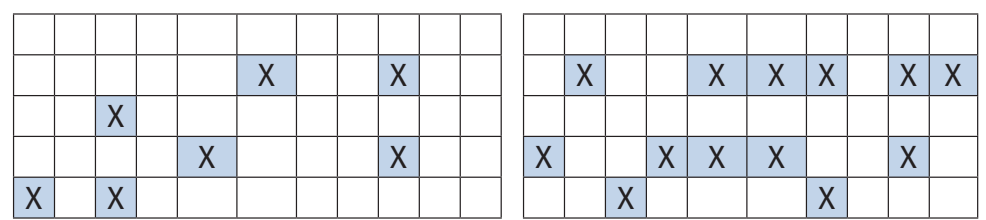

PYRROPHYTA (dinoflagellates)

Ceratium hirundinella

Glenodinium palustre

Glenodinium quadridens

Glenodinium sp.

Gymnodinium palustre

Peridinium inconspicuum

Peridinium sp.
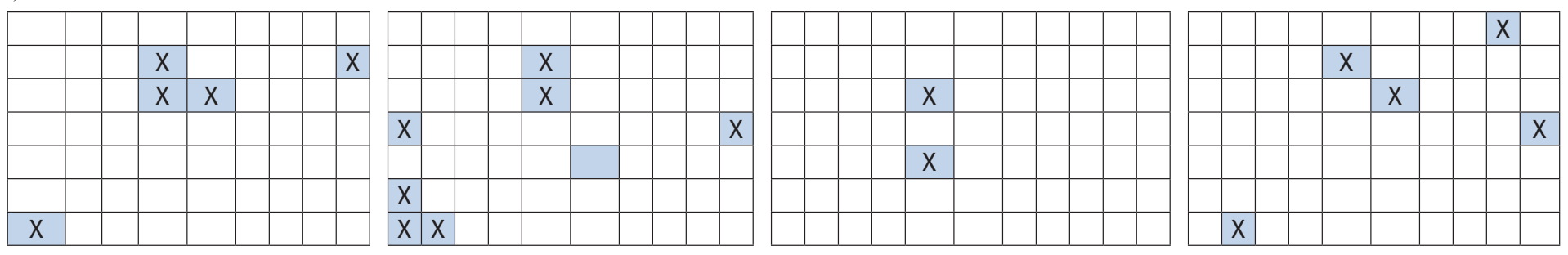

Total number of taxa

by date and location

$\begin{array}{lllllllll}15 & 25 & 52 & 39 & 23 & 22 & 26 & 36 & 28\end{array}$

$16204637 \quad 35$

$25 \quad 22 \quad 23 \quad 28 \quad 28$

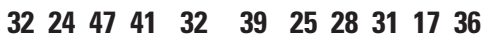

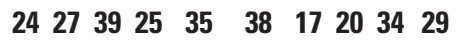

*Two separate samples, replication 1 and 2 , were collected from this location on this date.

Species richness 2011-2012: 193

Species richness 2013-2014: 100

Species richness: Total number of taxa occurring in Topock during 2011-2014 $=240$ 

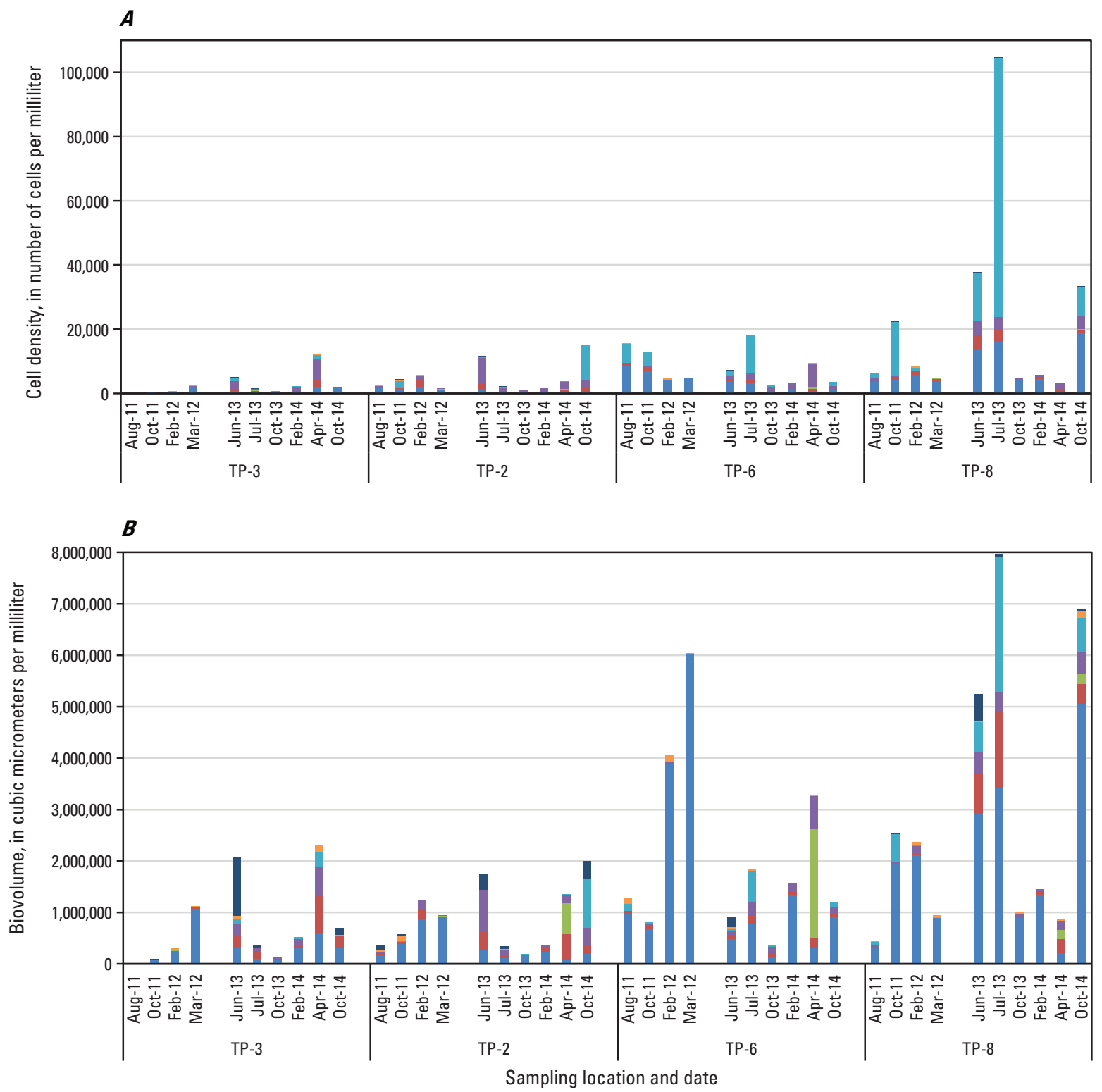

EXPLANATION

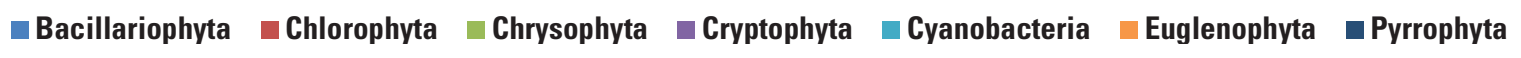

Figure 23. Density and biovolume of phytoplankton data from sampling stations in Topock Marsh, Arizona, from August 2011 to October 2014. $A$, total density and $B$, biovolume of phytoplankton. Note stations are shown in upstream to downstream order. (TP, sampling station) 
Table 11. Zooplankton taxa collected in Topock Marsh at each sampling station on each sampling date.

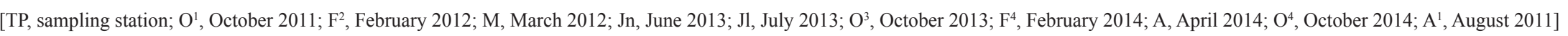

\begin{tabular}{|c|c|c|c|c|c|c|c|c|c|c|c|c|c|c|c|c|c|}
\hline Taxonomy & \multicolumn{4}{|c|}{ TP-3 } & \multicolumn{4}{|c|}{ TP-2 } & \multicolumn{5}{|c|}{ TP-6 } & \multicolumn{4}{|c|}{ TP-8 } \\
\hline Phylum, Class, or Order & 2011 & 2012 & 2013 & 2014 & 2011 & 2012 & 2013 & 2014 & 2011 & 2012 & 2013 & & 2014 & 20112 & 2012 & 2013 & 2014 \\
\hline Genus species & $0^{1}$ & $F^{2} M$ & Jn Jl $\mathbf{0}^{3}$ & $\begin{array}{lll}F^{4} & \text { A } & \mathbf{O}^{4}\end{array}$ & $\begin{array}{ll}A^{1} & 0^{1}\end{array}$ & $F^{2} \quad M$ & Jn $\mathrm{Jl}^{\mathbf{3}}$ & $\begin{array}{lll}\mathbf{F}^{4} & \mathbf{A} & \mathbf{O}^{4}\end{array}$ & $\begin{array}{ll}A^{1} & 0^{1}\end{array} \mid$ & $F^{2} \mathbf{M}$ & Jn $\mathrm{Jl}^{3}$ & $F^{4} \quad A$ & A $0^{4}$ a & \begin{tabular}{ll|l}
$A^{1}$ & $0^{1}$ & $F$
\end{tabular} & $F^{2} M$ & Jn Jl $0^{3}$ & $\mathrm{~F}^{4} \quad \mathrm{Al}^{4}$ \\
\hline
\end{tabular}

\section{CLADOCERA}

Alona affinis

Alona guttata

Bosmina longirostris

Ceriodaphnia spp.

Chydorus spp.

Chydorus sphaericus

Daphnia ambigua

Daphnia lumholtzi ${ }^{\text {b }}$

Daphnia parvula

Daphnia spp.

Diaphanosoma brachyurum

Eubosmina longispina

Latona parviremis

Sida crystallina

Simocephalus serrulatus

Simocephalus spp.
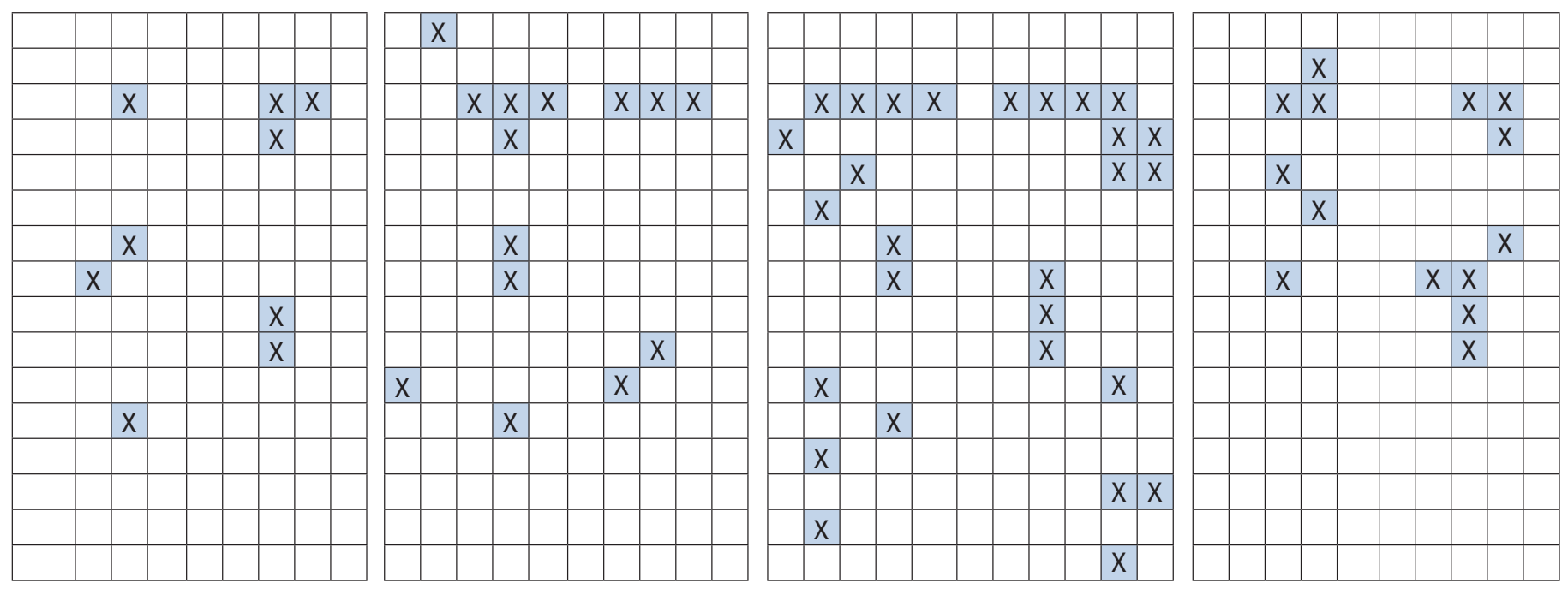

\section{COPEPODA}

Acanthocyclops robustus

Acanthocyclops vernalis (cyclopoid)

Leptodiaptomus siciloides

Mesocyclops edax

Tropocyclops prasinus (cyclopoid)

calanoid

cyclopoid

nauplii
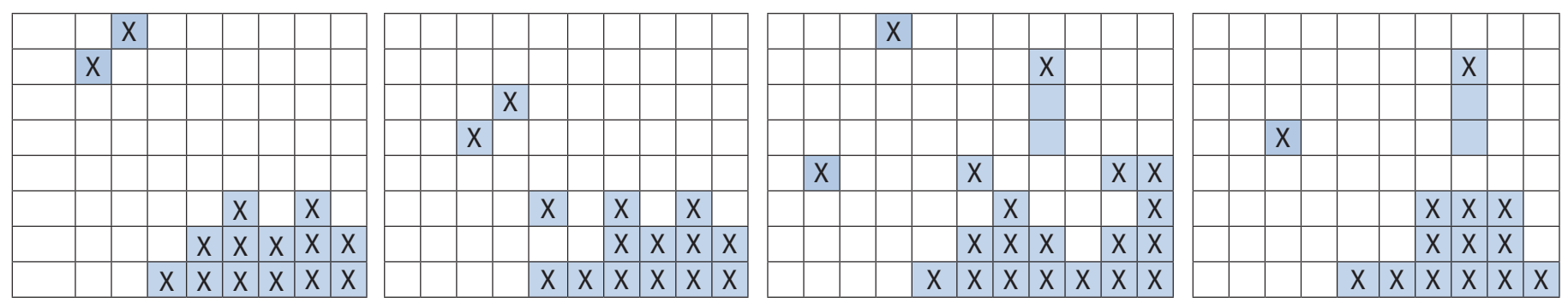

\section{ROTIFERA}

Anuraeopsis fissa

Ascomorpha ovalis

Asplanchna priodonta

bdelloid

Brachionus angularis
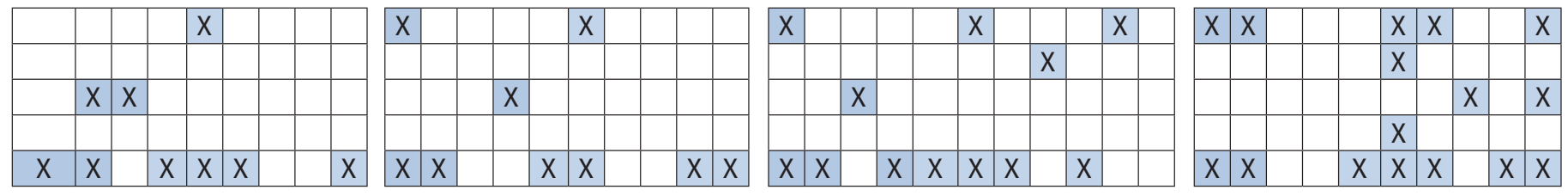
Table 11. Zooplankton taxa collected in Topock Marsh at each sampling station on each sampling date.-Continued

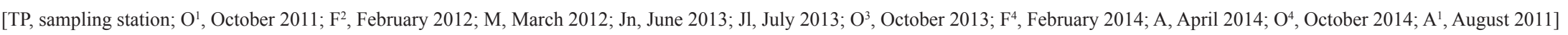

\begin{tabular}{|c|c|c|c|c|c|c|c|c|c|c|c|c|c|c|c|c|c|c|c|c|c|c|c|c|c|c|c|c|c|c|c|c|c|c|c|c|c|c|c|c|c|}
\hline \multirow{3}{*}{$\begin{array}{c}\text { Taxonomy } \\
\text { Phylum, Class, or Order } \\
\text { Genus species }\end{array}$} & \multicolumn{9}{|c|}{ TP-3 } & \multicolumn{10}{|c|}{ TP-2 } & \multicolumn{12}{|c|}{ TP-6 } & \multicolumn{10}{|c|}{ TP-8 } \\
\hline & \multirow{3}{*}{$\begin{array}{c}2011 \\
0^{1}\end{array}$} & \multirow{2}{*}{\multicolumn{2}{|c|}{$\begin{array}{l}2012 \\
F^{2} \quad M\end{array}$}} & \multirow{2}{*}{\multicolumn{3}{|c|}{$\begin{array}{c}2013 \\
\text { Jn J } 0^{3}\end{array}$}} & \multicolumn{3}{|c|}{2014} & & 11 & 20 & 12 & & 13 & & & 014 & & 20 & 11 & & 012 & & 2013 & & & & 014 & & & 201 & & & 12 & & 2013 & & & 201 & \\
\hline & & & & & & & $F^{4}$ & & $0^{4}$ & & $\mathbf{0}^{1}$ & & $\mathbf{M}$ & Jn & & $0^{3}$ & $F^{4}$ & & $0^{4}$ & & $\mathbf{0}^{1}$ & & $\mathbf{M}$ & Jn & ال & $0^{3}$ & $\mathbf{F}^{4}$ & A & & $\mathbf{0}^{4}$ & & & $\mathbf{0}^{1}$ & & $\mathbf{M}$ & & n ال & $0^{3}$ & & $4 \mathrm{~A}$ & $0^{4}$ \\
\hline Brachionus caudatus & & & & & $\mathrm{X}$ & & & & & & & & & & $\bar{x}$ & & & & & & & & & $X$ & $x$ & $\mathrm{X}$ & & $x$ & & & & & & & & $\mathrm{X}$ & $x$ & & & $X$ & \\
\hline Brachionus patulus & & $x$ & & & & & & & & $\mathrm{X}$ & & & & & & & & & & $\mathrm{X}$ & $\mathrm{X}$ & & & & & & & & & & & & & & & & & & & & \\
\hline Brachionus quadridentatus f. brevispinus & & & & & & & & & & & & & & & & & & & & & & & & & & & & & & & & & & & & & & & & & $\mathrm{X}$ \\
\hline Brachionus variabilis & & $\mathrm{X}$ & $X$ & & & & $\mathrm{X}$ & & & & & & $X$ & & & & $x$ & & & & & & $\mathrm{X}$ & & & & $\mathrm{X}$ & & & & & & & $\mathrm{X}$ & $\mathrm{X}$ & & & & $\mathrm{X}$ & & \\
\hline Cephalodella spp. & & & & & & & & & & & & & & & $x$ & & & & & & & & & & & & & & & & & & & & & & & & & & \\
\hline Collotheca spp. & & & & & & & & $\mathrm{X}$ & & & & & & & & & & $\mathrm{X}$ & & & & & & & & & & & & & & & & & & & & & & & \\
\hline Conochiloides dossuarius & & & & & & & & & & & & & & & & & & $\mathrm{X}$ & & & & & & & & & & & & & & & & & & & $\mathrm{X}$ & & & & \\
\hline Conochilus spp. & & & $X$ & & & & & & & & & & $\mathrm{X}$ & & & & & & & & & & & & & & & & & & & & & & & & & & & & $X$ \\
\hline Conochilus unicornis & & & & & & & $\mathrm{X}$ & & & & & & & & & & $\mathrm{x}$ & $\mathrm{X}$ & & & & & $\mathrm{X}$ & & & & $\mathrm{X}$ & $x$ & & & & & & & $X$ & & & & $\mathrm{X}$ & & \\
\hline Euchlanis spp. & & & & & & & & & & & & & & & & $\mathrm{X}$ & & & & & & & & & & & & & & & & & & & & & & & & & \\
\hline Filinia longiseta & $\mathrm{X}$ & & & $\mathrm{X}$ & $\mathrm{X}$ & & $\mathrm{X}$ & $X$ & & $\mathrm{X}$ & $\mathrm{X}$ & & & $X$ & $x$ & $\mathrm{X}$ & $\mathrm{X}$ & $\mathrm{X}$ & $\mathrm{X}$ & $\mathrm{X}$ & $X$ & & & $\mathrm{X}$ & $\mathrm{X}$ & $\mathrm{x}$ & & & & & & $\mathrm{X}$ & $X$ & & & $X$ & $x$ & & & & \\
\hline Gastropus stylifer & & & & & & & & $X$ & & & & & & & & & & & & & & & & & & & & $x$ & & & & & & & & & & & & & \\
\hline Hexarthra mira & & & & $\mathrm{X}$ & & & & & $\mathrm{X}$ & & & & & $X$ & & & & & $\mathrm{X}$ & $\mathrm{X}$ & & & & $x$ & $\mathrm{X}$ & & & & $x$ & & $\bar{X}$ & & & & & & $x$ & & & & \\
\hline Keratella americana & $\mathrm{X}$ & & & & & $\mathrm{X}$ & & & & & & & & & & $x$ & & & & & & & & & & $\mathrm{X}$ & & $x$ & & & & & & & & & & $X$ & & & \\
\hline Keratella cochlearis & & & & $X$ & & & $\mathrm{X}$ & $X$ & $X$ & & & & & $X$ & & & $x$ & $\mathrm{X}$ & $X$ & & & & & $X$ & $x$ & & $\mathrm{X}$ & $X$ & $x$ & & $x$ & & & & & $X$ & $x$ & & & $\mathrm{X}$ & $x$ \\
\hline Keratella cochlearis f. tecta & & & & & & & & & & & & & & & & & & & & & & & & & & & & & & & & & & & & & & & & & \\
\hline Keratella quadrata & & $\mathrm{X}$ & $\mathrm{X}$ & & & & $\mathrm{X}$ & $\mathrm{X}$ & & & & $x$ & $x$ & & $\mathrm{X}$ & & $x$ & $\mathrm{X}$ & & & & $X$ & $X$ & $\mathrm{X}$ & & & $\mathrm{X}$ & $x$ & $x$ & र & & & & $\mathrm{X}$ & $X$ & & & & $\mathrm{X}$ & $x$ & \\
\hline Keratella testudo & & & & & & & & & & & $\mathrm{X}$ & & & & & & & & & & & & & & & & & & & & & & & & & & & & & & \\
\hline Keratella tropica & & $\mathrm{X}$ & $X$ & & & & $\mathrm{X}$ & & & & & $X$ & $X$ & & & & $x$ & & & & & $X$ & $X$ & $x$ & & & $\mathrm{X}$ & & & & & & & $X$ & $X$ & & & & $\mathrm{X}$ & & \\
\hline Lecane spp. & & & & & & & & & & & & & $X$ & & & & $x$ & & & & & & & & & & & & & & & & & & & & & & & & \\
\hline Lecane crepida & & & & & & & & & & & & & & & & & & & & & & & & & & & & & & & $\mathrm{X}$ & & & & & & & & & & \\
\hline Lepadella ovalis & & & & & & & & & & & & & & $X$ & & & & & & & & & & & & & & & & & & & & & & & & & & & \\
\hline Liliferotrocha spp. & & & & & & & & & & & & & & & $\mathrm{X}$ & & & & $\mathrm{X}$ & & & & & & & & & & & & & & & & & & $\mathrm{X}$ & & & & $\mathrm{X}$ \\
\hline Monostyla bulla & & & & & & & & & & & & & & & & & & & $\mathrm{X}$ & & $X$ & $X$ & & & & & & & & & $X$ & & & & & & & & & & \\
\hline Monostyla lunaris & & & & & & & & & & & & & $X$ & & $x$ & & & & & & & & & & & & & & & & & & & & & & & & & & \\
\hline Notholca acuminata & & & & & & & & & & & & & $X$ & & & & & & & & & & & & & & & & & & & & & & & & & & & & \\
\hline c.f. Paradicranophorus spp. & & & & & & & & & & & & & $X$ & & & & & & & & & & $X$ & & & & & & & & & & & & & & & & & & \\
\hline Plationus patulus & & & & $\mathrm{X}$ & $\mathrm{X}$ & & & & $X$ & & & & & $X$ & $\mathrm{X}$ & & & & $\mathrm{X}$ & & & & & $X$ & $\mathrm{X}$ & & & & $\underline{x}$ & $x$ & & & & & & & & & & & \\
\hline Polyarthra dolichoptera & & $\mathrm{X}$ & $X$ & & & & & & & & & $X$ & & & & & & & & & & $\mathrm{X}$ & $X$ & & & & & & & & & & & & & & & & & & \\
\hline Polyarthra remata & & & & $x$ & $\mathrm{X}$ & $\mathrm{X}$ & & & & & & & $X$ & $\mathrm{X}$ & $x$ & $X$ & & & & & & & & $X$ & & $\mathrm{X}$ & & $x$ & & & & & & & & & $\mathrm{X}$ & $X$ & & $\mathrm{X}$ & \\
\hline Polyarthra vulgaris & $X$ & $\mathrm{X}$ & $X$ & $\mathrm{X}$ & $\mathrm{X}$ & $\mathrm{X}$ & & $\mathrm{X}$ & $X$ & $\mathrm{X}$ & $\mathrm{X}$ & $\mathrm{X}$ & $X$ & $X$ & $X$ & $X$ & $\mathrm{X}$ & $\mathrm{X}$ & $\mathrm{X}$ & $\mathrm{X}$ & $X$ & $X$ & $X$ & $X$ & $\mathrm{X}$ & $\mathrm{X}$ & $\mathrm{X}$ & $X$ & $x$ & $x)$ & $X$ & $X$ & $\mathrm{X}$ & $X$ & $\mathrm{X}$ & $X$ & $x$ & $X$ & $X$ & & $\mathrm{X}$ \\
\hline Synchaeta spp. & & & & & & $\mathrm{X}$ & & $X$ & & & & & & $\mathrm{X}$ & & $\mathrm{X}$ & & $\mathrm{X}$ & $\mathrm{X}$ & & & & & $\mathrm{X}$ & & $\mathrm{X}$ & & & & & & & & & & & $\mathrm{X}$ & $\mathrm{X}$ & & $\mathrm{X}$ & \\
\hline Testudinella patina & & & & & & & & & & & & & & $X$ & & & & & & & & & & & & & & & & & & & & & & & & & & & \\
\hline Trichocerca multicrinis & & & & & $\mathrm{X}$ & & & & & & & & & & & & & & & & & & & & & & & & & & & & & & & & & & & & \\
\hline Trichocerca pusilla & & & & & & & & & & & & & & & & & & & & & & & & & & & & & & & & $X$ & $X$ & & & & $X$ & & & & \\
\hline
\end{tabular}


Table 11. Zooplankton taxa collected in Topock Marsh at each sampling station on each sampling date.-Continued

[TP, sampling station; $\mathrm{O}^{1}$, October 2011; F², February 2012; M, March 2012; Jn, June 2013; Jl, July 2013; O³, October 2013; F4, February 2014; A, April 2014; O4, October 2014; A ${ }^{1}$, August 2011]

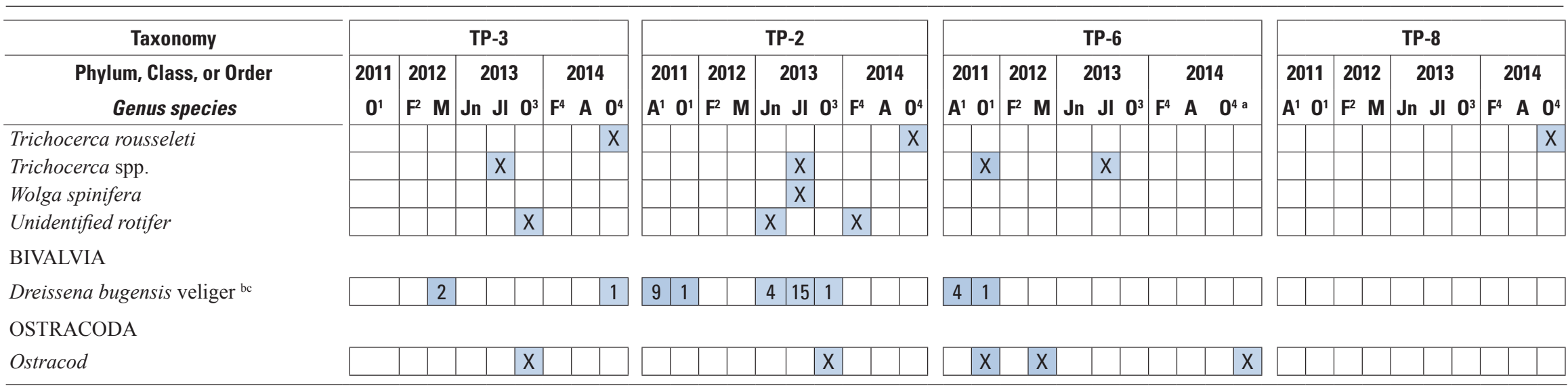

\section{Total number of taxa by date}

and location

$\begin{array}{llllllllllllllllllllllllllllllllllllllll}4 & 10 & 12 & 8 & 11 & 10 & 12 & 11 & 9 & 7 & 6 & 6 & 17 & 15 & 15 & 13 & 13 & 13 & 12 & 8 & 14 & 8 & 14 & 13 & 12 & 11 & 14 & 11 & 15 & 13 & 5 & 5 & 8 & 8 & 6 & 15 & 10 & 14 & 12 & 10\end{array}$

${ }^{a}$ Two separate samples, replication 1 and 2 , were collected from this location on this date.

${ }^{\mathrm{b}}$ Nonnative species.

${ }^{\mathrm{c}}$ Values provided are the number of individual veligers collected in footnote $\mathrm{c}$ in plankton tows where this taxon was present Species richness 2011-2012: 45

Species richness 2013-2014: 52

Species richness: Total number of taxa occurring in Topock during 2011-2014 $=67$ 

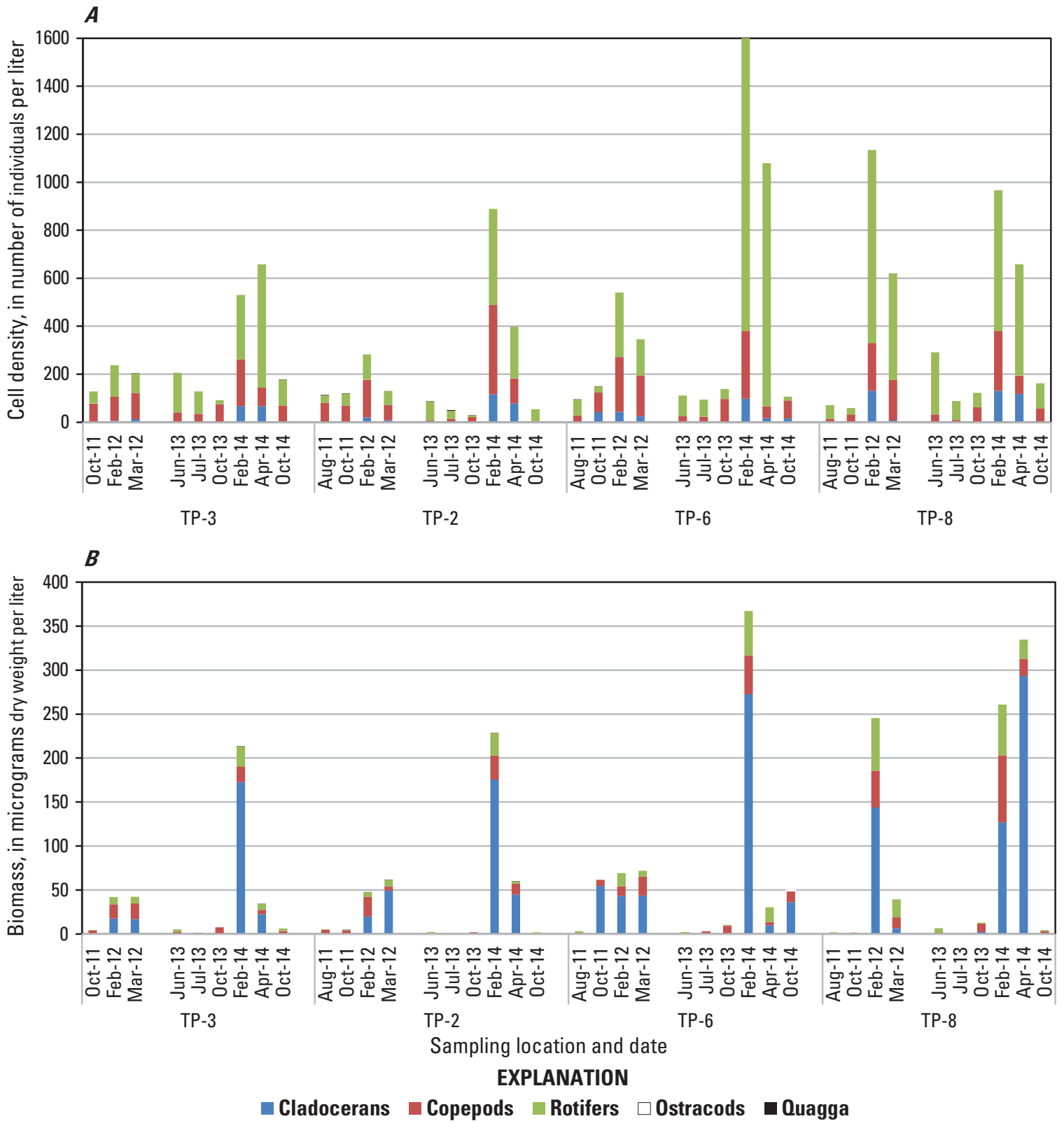

Figure 24. Density and biomass of zooplankton data from sampling stations in Topock, Arizona, from 0ctober 2011 to 0 ctober 2014. $A$, total density and $B$, biomass of zooplankton. Note stations are shown in upstream to downstream order. (TP, sampling station) 


\section{Small Biota Sampling}

Species richness of the aquatic macroinvertebrate taxa collected in Topock Marsh was 41 during 2011-12 and 72 during 2013-14 (table 12). There are no macroinvertebrate data for July 2011 because the shipping service lost all samples. During the entire 4-year study period, gastropods (specifically Physa sp.) and chironomids (several in the Chironomidae family) were abundant in all seasons. However, other taxa were also numerous at various times and places. For example, there were relatively high numbers of mayflies (Caenis sp.) in March 2012 at TP-2 and in June 2013 at TP-2 and TP-3; grass shrimp (Palaemonetes sp.) in October 2013 at TP-8; water boatman (Corixidae) larvae in February 2012 at TP-8, in March 2012 at TP-2, and in April 2014 at TP-8; and aquatic oligochaete worms (Oligochaeta) in June 2013 at TP-2, in February 2014 at TP-8, in April 2014 at TP-2, and in October 2014 at TP-2 and TP-8 (table 12). The fewest number of macroinvertebrates (201 individuals) were collected in July 2013, and the largest number (1,871 individuals) were collected in October 2013. Generally, each October tended to have the highest number of individual organisms (range $=611$ to 1,871 ), but the highest number of taxa were collected in June 2013 (42 taxa) and April 2014 (41 taxa). Species richness ranged from 18 to 34 taxa per visit for the other 8 sampling trips. Large variations occurred between the sampling stations as well. Throughout the 10 sampling trips, TP- 8 had the highest total number of individual organisms (mean $=321$ individual macroinvertebrates) compared to the other sampling stations (mean number of individual invertebrates were 68, 178, and 109 for TP3, TP-2, and TP-6, respectively).

Adult quagga mussels (Dreissena bugensis) were first discovered in Topock Marsh in a sweep net sample from March 2012 at sampling station TP-2, where the Fire Break Canal flows into the marsh from the Colorado River. From sweep net samples, 12 quagga mussel adults (at least 1 from each sampling station) were collected in 2013, and 9 adults were collected in February 2014 (3 at station TP-3 and 6 at TP-2). No adults were collected in April 2014 or October 2014. Quagga mussel veligers (larval stage) were collected in zooplankton samples from TP-2 and TP-6 in August and September 2011, and from TP-3 in March 2012 (table 11). Several veligers were collected at TP-2 in June, July, and October 2013, and one individual was collected from TP-3 in October 2014 (table 11).

\section{Fish Sampling}

Gill net surveys were conducted by AGFD in the marsh each February from 2010 to 2015. These fish data, which were provided by Gregg Cummins of the AGFD, Region III Office in Kingman, Arizona, are presented in appendix 2 and are summarized in table 13. Locations where the 10 gill nets were set each year are illustrated in figures $25 A$ and $25 B$ and the number of fish captured each year within the entire marsh is provided in figure 26 . The gill net data in table 13 are assembled into five regions: the north end, Fire Break Canal, Beal Lake outlet, Catfish Paradise, and South Dike.

The total number of fish caught in gill nets increased from 2010-15 at all five regions except Catfish Paradise, where numbers remained relatively the same (table 13). However, gizzard shad (Dorosoma cepedianum) first appeared in Topock Marsh in August 2011 (Mitch Thorson, AZFWCO, written comm., 2011) and quickly proliferated in subsequent years (fig. 26). If gizzard shad numbers are excluded from the totals, the trend of steadily increasing numbers is no longer apparent (table 13). Two game species were captured in increasing numbers throughout the marsh: striped bass (Morone saxatilis) had peaks in 2012, 2014, and 2015; and channel catfish numbers more than doubled in 2013-15 (fig. 26). However, largemouth bass declined steadily from 2010-15. If we look at changes during time among the five regions, the numbers of fish captured per net varies depending on species (table 13). Striped bass increased between 2010 and 2015 in the north end and near the Fire Break Canal inlet. At all five regions, channel catfish (Ictalurus punctatus) showed a general increase from 2010 through 2015, and the largest increases were observed at the north end, Firebreak Canal inlet, and Catfish Paradise. Largemouth bass were found in highest numbers at the north end in 2010-11 and then declined precipitously, and a similar trend was seen at Catfish Paradise, but capture numbers in the other three regions showed no clear trend. Razorback sucker, the only native fish in Topock Marsh and a federally endangered species, was reintroduced in 2010 and most frequently captured near the South Dike. Numbers of razorback suckers increased in the marsh until 2012, but declined in 2013-14, and no razorback suckers were captured in 2015 (table 13 and fig. 26). 
Table 12. Macroinvertebrate taxa and number of individuals collected in Topock Marsh at each sample station on each sampling date.

[TP, sampling station; S, September 2011; O', October 2011; JF, January/February 2012; M, March 2012; Jn, June 2013; J1, July 2013; O³, October 2013; F, February 2014; A, April 2014; O4, October 2014]

\begin{tabular}{|c|c|c|c|c|c|c|c|c|c|c|c|c|c|c|c|c|c|c|c|c|c|c|c|c|c|c|c|c|c|c|c|c|c|c|c|c|c|c|c|c|}
\hline \multirow{3}{*}{$\begin{array}{l}\text { PHYLUM; CLASS or } \\
\text { SUBCLASS; Order or } \\
\text { Suborder; Family; } \\
\text { Subfamily or Tribe; } \\
\text { Genus species }\end{array}$} & \multicolumn{10}{|c|}{ TP-3 } & \multicolumn{10}{|c|}{ TP-2 } & \multicolumn{10}{|c|}{ TP-6 } & \multicolumn{10}{|c|}{ TP-8 } \\
\hline & \multicolumn{2}{|c|}{2011} & \multicolumn{2}{|c|}{2012} & \multicolumn{3}{|c|}{2013} & \multicolumn{3}{|c|}{2014} & \multicolumn{2}{|c|}{2011} & \multicolumn{2}{|c|}{2012} & & 2013 & & & 2014 & & 201 & & 201 & & & 2013 & & & 2014 & & 201 & & 201 & & & 2013 & & & 2014 & \\
\hline & $\mathbf{s}$ & $0^{1}$ & JF & $\mathbf{M}$ & $\mathbf{J n}$ & JI & $0^{3}$ & $\mathbf{F}$ & A & $0^{4}$ & $\mathbf{s}$ & $0^{1}$ & $\mathbf{J F}$ & $\mathbf{M}$ & Jn & JI & $0^{3}$ & $\mathbf{F}$ & A & $0^{4}$ & $\mathbf{S}$ & $0^{1}$ & $\mathbf{J F}$ & M & $\mathbf{J n}$ & Jl & $0^{3}$ & $\mathbf{F}$ & A & $0^{4}$ & $\mathbf{S}$ & $0^{1}$ & $\mathbf{J F}$ & M & $\mathbf{J n}$ & JI & $0^{3}$ & $\mathbf{F}$ & A & $3^{4}$ \\
\hline ARTHROPODA & & & & & & & & & & & & & & & & & & & & & & & & & & & & & & & & & & & & & & & & \\
\hline COLLEMBOLA & & & & & & & & & 1 & & & & & & & & & & & & & & & & & & & & & & & & & & & & & & & \\
\hline Sminthuridae & & & & & & & & & & & & & & & 1 & & & & & & & & & & & & & & & & & & & & & & & & & \\
\hline INSECTA & & & & & & & & & & & & & & & & & & & & & & & & & & & & & & & & & & & & & & & & \\
\hline Ephemeroptera & & & & & & & & & & & & & & & & & & & & & & & & & & & & & & & & & & & & & & & & \\
\hline Baetidae & & & & & & & & & & & & & & & & & & & & & & & & & & & & & & & & & & & & & & & & \\
\hline Acentrella sp. & & & & & & & & & & & & & & & & & & & 3 & & & & & & & & & & & & & & & & & & & & & \\
\hline Caenis sp. & 4 & 1 & & 2 & 66 & 10 & 6 & 12 & 29 & & 5 & 4 & 1 & 61 & 74 & 1 & 3 & 4 & 10 & & 2 & & 1 & 6 & 1 & & 2 & & 5 & & 5 & 7 & 13 & & 2 & 4 & 1 & & 28 & 5 \\
\hline Callibaetis sp. & & & & & & & & & & & & & & & & & & & & & & & & & & & & & & & & & & & & & 1 & & & \\
\hline Odonata & & & & & & & & & & & & & & & & & & & & & & & & & & & & & & & & & & & & & & & & \\
\hline Aeshnidae & & & & & & & 1 & & & & & & & & & & 8 & & & & & & & & & & & & 1 & & & & & & 1 & & & & & \\
\hline Anaxsp. & & & & & & & 2 & & & & & & & & & & 3 & & & & 1 & 6 & & . & & & 2 & & & 1 & 1 & 2 & & & & & & & & \\
\hline Coenagrionidae & 12 & 16 & & 1 & 3 & 1 & 6 & 2 & & 1 & 3 & 4 & & 5 & 13 & 1 & 12 & 2 & 1 & & 36 & 6 & & 1 & 1 & & 4 & 2 & 12 & & 4 & 3 & 1 & & 6 & 3 & 18 & & 6 & 3 \\
\hline Argia sp. & & & & & & & & & & & & & & 1 & & & & & & & & & & & & & & & & & & & & & & & & & & \\
\hline Ischnura sp. & & & & & & & 1 & & & & & & & & & & & & & & & & & & & & & & & & & & & & & & 15 & & & \\
\hline Libellulidae & & & & & 1 & & & & & & 1 & & & & & & 1 & & & & 2 & & & & & & & & & & & & & & & & & & & \\
\hline Heteroptera & & & & & & & & & & & & & & & & & & & & & & & & & & & & & & & & & & & & & & & & \\
\hline Corixidae & & & & & & & & & & & & & & & & & & & & & & & & & & & & & & & & & & & & & & & & \\
\hline Corixidae larvae & 1 & 2 & & 1 & & & & & 4 & & & & 4 & 75 & 2 & & 1 & 3 & 19 & & 2 & & 8 & 2 & & & & & & & & & 231 & 1 & 1 & 1 & & & 53 & \\
\hline Trichocorixa calva & & & & & & & & & & & & & 18 & 3 & & & & 3 & & & & & 6 & 2 & & & & 2 & & & & & 62 & & & & & & 2 & \\
\hline Hydrometridae & & & & & & & & & & & & & & & & & & & & & & & & & & & & & & & & & & & & & & & & \\
\hline Hydrometra sp. & & & & & & & & & & & & & & & & & & & & & & & & & & & & & 1 & & & & & & & & & & & \\
\hline Trichoptera & & & & & & & & & & & & & & & & & & & & & & & & & & & & & & & & & & & & & & & & \\
\hline Hydroptilidae & & & & & & & & & & & & & & & & & & & & & & & & & & & & & & & & & & & & & & & & \\
\hline Neotrichia sp. & & & & & 2 & 4 & & & & & & & & & & & & & & & & & & & & & & & & & & & & & & & & & & \\
\hline Oxyethira sp. & & & & & 1 & & & & 9 & & 1 & & & & 2 & & & & & & & & & & 1 & & & & \begin{tabular}{l|l}
6 \\
\end{tabular} & & & & & & & & & & & \\
\hline Leptoceridae & & & & & & & & & & & & & & & & & & & & & & & & & & & & & & & & & & & & & & & & \\
\hline Oecetis sp. & & & & & & & & & & & & & & & & & & & & & & & & & & & & & & & & & & 2 & & & & & 2 & \\
\hline Coleoptera & & & & & & & & & & & & & & & & & & & & & & & & & & & & & & & & & & & & & & & & \\
\hline Hydrophilidae & & & & & & & & & & & & & & & & & & & & & & & & & & & & & & & & & & & & & & & & \\
\hline Berosus sp. & & & & & & & & & & & & & & & & & & & & & & & & & & & & & & & & & & & & & & & 2 & \\
\hline Paracymus sp. & & & & & & & & & & & & & & & & & 1 & & & & & & & & & & & & & & & & & & & & & & & \\
\hline Staphylinidae & & & & & & & & & & & & & & & & & & 1 & & & & & & & & & & & & & & & & & & & & & & \\
\hline
\end{tabular}


Table 12. Macroinvertebrate taxa and number of individuals collected in Topock Marsh at each sample station on each sampling date.-Continued

\begin{tabular}{|c|c|c|c|c|c|c|c|c|c|c|c|c|c|c|c|c|c|c|c|c|c|c|c|c|c|c|c|c|c|c|c|c|c|c|c|c|c|c|c|c|}
\hline \multirow{3}{*}{$\begin{array}{l}\text { PHYLUM; CLASS or } \\
\text { SUBCLASS; Order or } \\
\text { Suborder; Family; } \\
\text { Subfamily or Tribe; } \\
\text { Genus species }^{\mathrm{a}}\end{array}$} & \multicolumn{10}{|c|}{ TP-3 } & \multicolumn{10}{|c|}{ TP-2 } & \multicolumn{10}{|c|}{ TP-6 } & \multicolumn{10}{|c|}{ TP-8 } \\
\hline & \multicolumn{2}{|c|}{2011} & \multicolumn{2}{|c|}{2012} & \multicolumn{3}{|c|}{2013} & \multicolumn{3}{|c|}{2014} & \multicolumn{2}{|c|}{2011} & \multicolumn{2}{|c|}{2012} & \multicolumn{3}{|c|}{2013} & & 2014 & & 201 & & 2012 & & & 2013 & & & 2014 & & 20 & 11 & 20 & & & 2013 & & & 2014 & \\
\hline & $\mathbf{s}$ & $0^{1}$ & JF & $\mathbf{M}$ & Jn & JI & $0^{3}$ & $\mathbf{F}$ & A & $0^{4}$ & $s$ & $0^{1}$ & JF & M & Jn & JI & $0^{3}$ & $\mathbf{F}$ & A & $0^{4}$ & $S$ & $0^{1}$ & JF & $\mathbf{M}$ & Jn & JI & $0^{3}$ & $\mathbf{F}$ & A & $0^{4}$ & $\mathbf{s}$ & $0^{1}$ & JF & $\mathbf{M}$ & Jn & JI & $0^{3}$ & $\mathbf{F}$ & A & $0^{4}$ \\
\hline Diptera & & & & & & & & & & & & & & & & & & & & & & & & & & & & & & & & & & & & & & & & \\
\hline Ceratopogonidae & & & & & & & & & & & & & & & & & & & & & & & & & & & & & & & & & & & & & & & & \\
\hline $\begin{array}{l}\text { Bezzia/Palpomyia } \\
\text { sp. }\end{array}$ & & & & & & & & & & & & & & & & & & & 1 & & & & & & & & & & 1 & & & & & & & & & & & \\
\hline Ceratopogoninae & & & & 2 & & & & & 5 & & & & & & 3 & & & & 1 & & & & & & 1 & 1 & & & & & & & & & & & & & & \\
\hline Ceratopogon sp. & & & & & & & & & & & & & & & & & & & 2 & & & & & & & & & & & & & & & & & & & & & \\
\hline Dasyhelea sp. & & & & & & & & & & & & & & & & & & & & & & & & & & & & & & & & & & 1 & & & & & & \\
\hline Chaoboridae & & & & & & & & & & & & & & & & & & & & & & & & & & & & & & & & & & & & & & & & \\
\hline Chaoborus sp. & & & & & & & & & & & & & & & & & & & & & & & & 1 & & & & & & & & & & & & & & & & \\
\hline Chironomidae & & & & & & & & & & & & & & & & & & & & & & & & & & & & & & & & & & & & & & & & \\
\hline$\underline{\text { Orthocladiinae }}$ & & & & & & & & & & & & & & & & & & & & & & & & & & & & & & & & & & & & & & & & \\
\hline Cricotopus sp. & & & & & & & & & & & & & & & & & & & & & & & & & & & & & 1 & & & & 1 & 1 & & & 15 & 1 & 23 & \\
\hline Chironomini & & & & & & & & & & & 1 & & & & & & & & & & & & & & & & & & & & & 11 & & & & & & & & \\
\hline Apedilum sp. & 1 & 1 & & & & & 1 & & & & & & & & & & 10 & & & & & & & & & & & & & & & 5 & 3 & & & & 14 & & & \\
\hline Chironomus sp. & & & & & & & & & & & & & & 81 & 2 & & & & & & & & 4 & 4 & 5 & 2 & & & & & & & 5 & & 2 & & 1 & 92 & 1 & \\
\hline Cladopelma sp. & 3 & 1 & & & & & & & & & 5 & 2 & & & & 1 & & & & & 6 & 8 & & & 1 & 37 & 3 & & & & & & 1 & & & & 2 & & & 20 \\
\hline $\begin{array}{l}\text { Cryptochironomus } \\
\text { sp. }\end{array}$ & 1 & 1 & & & 1 & & & 6 & 1 & & & & & 12 & & & & 2 & 2 & 7 & & & & & 1 & & 1 & & & & & & & & & & & & & 6 \\
\hline Dicrotendipes sp. & 1 & 1 & & 1 & & & 2 & 1 & & & & 1 & & & & & 2 & 2 & & & 2 & 15 & & & 14 & 7 & & & & & & & 10 & 1 & & & & & & \\
\hline $\begin{array}{l}\text { Endochironomus } \\
\text { sp. }\end{array}$ & & & & & & & & & & & & & & & & & & & & & & & & & 1 & & 1 & & 1 & & 14 & 108 & 2 & & 1 & & 6 & & 10 & 4 \\
\hline $\begin{array}{l}\text { Goeldichironomus } \\
\text { sp. }\end{array}$ & & & & & & & & & & & & & & & & & & & & & & & & & & & & & & & & & & & & & 371 & & & 76 \\
\hline $\begin{array}{l}\text { Microchironomus } \\
\text { sp. }\end{array}$ & & & & & & & & & & & & & & & & & & & & 3 & & & & & & & & & & & & & & & & & & & & \\
\hline $\begin{array}{l}\text { Parachironomus } \\
\text { sp. }\end{array}$ & 6 & 2 & & & & 2 & 17 & 2 & & 3 & 4 & 1 & & & & & 1 & & & & & & & & 1 & & 15 & & & 8 & & 29 & 1 & & 3 & & 61 & & & 5 \\
\hline Polypedilum sp. & & & & & & & & 1 & & & 1 & & & & & & & & & & \begin{tabular}{|l|}
83 \\
\end{tabular} & & 3 & & & 1 & & & & & & 1 & 6 & & 31 & & 7 & 1 & 1 & 14 \\
\hline$\underline{\text { Tanytarsini }}$ & & & & & & & & & & & & & & & & & & & & & & & & & & & & & & & & & & & & & & & & \\
\hline $\begin{array}{l}\text { Cladotanytarsus } \\
\text { sp. }\end{array}$ & & & & & & & & & & & 1 & & & & & & & 3 & & & & & & & & & & & & & & & 1 & & & & & & & \\
\hline Tanytarsus sp. & & & & & & & & & & & & & & & & & & & 1 & & & & & & 5 & 1 & & & & & & & 1 & & 1 & & & & & \\
\hline Tanypodinae & & & & & & & & & & & & & & & & & & & & & & & & & & & & & & & & & & & & & & & & \\
\hline Ablabesmyia sp. & 5 & & & & & & & & 1 & & & & & & & & & & 3 & & & & & & & & & & & 3 & & & & & & & & & & \\
\hline Procladius sp. & & & & 1 & & & & & 1 & & & & 1 & 211 & & & & 1 & 7 & 19 & & & & & & & & & & & & & & & & & & 4 & 3 & 4 \\
\hline Tanypus sp. & & & & & & 2 & & & & & & & & & 1 & & & 1 & 10 & 78 & & & & & 2 & 3 & 2 & & 1 & & & & 2 & & 1 & & & 4 & & 1 \\
\hline Stratiomyidae & & & & & & & & & & & & & & & & & & & & & & & & & & & & & & & & & & & & & & & & \\
\hline $\begin{array}{l}\text { Odontomyia/ } \\
\text { Hedriodiscus sp. }\end{array}$ & & & & & & & & & & & & & & & & & & & & & & & & & & & & & & & & & & & 1 & & & & & \\
\hline
\end{tabular}


Table 12. Macroinvertebrate taxa and number of individuals collected in Topock Marsh at each sample station on each sampling date.—Continued

[TP, sampling station; S, September 2011; O', October 2011; JF, January/February 2012; M, March 2012; Jn, June 2013; Jl, July 2013; O³, October 2013; F, February 2014; A, April 2014; O4, October 2014]

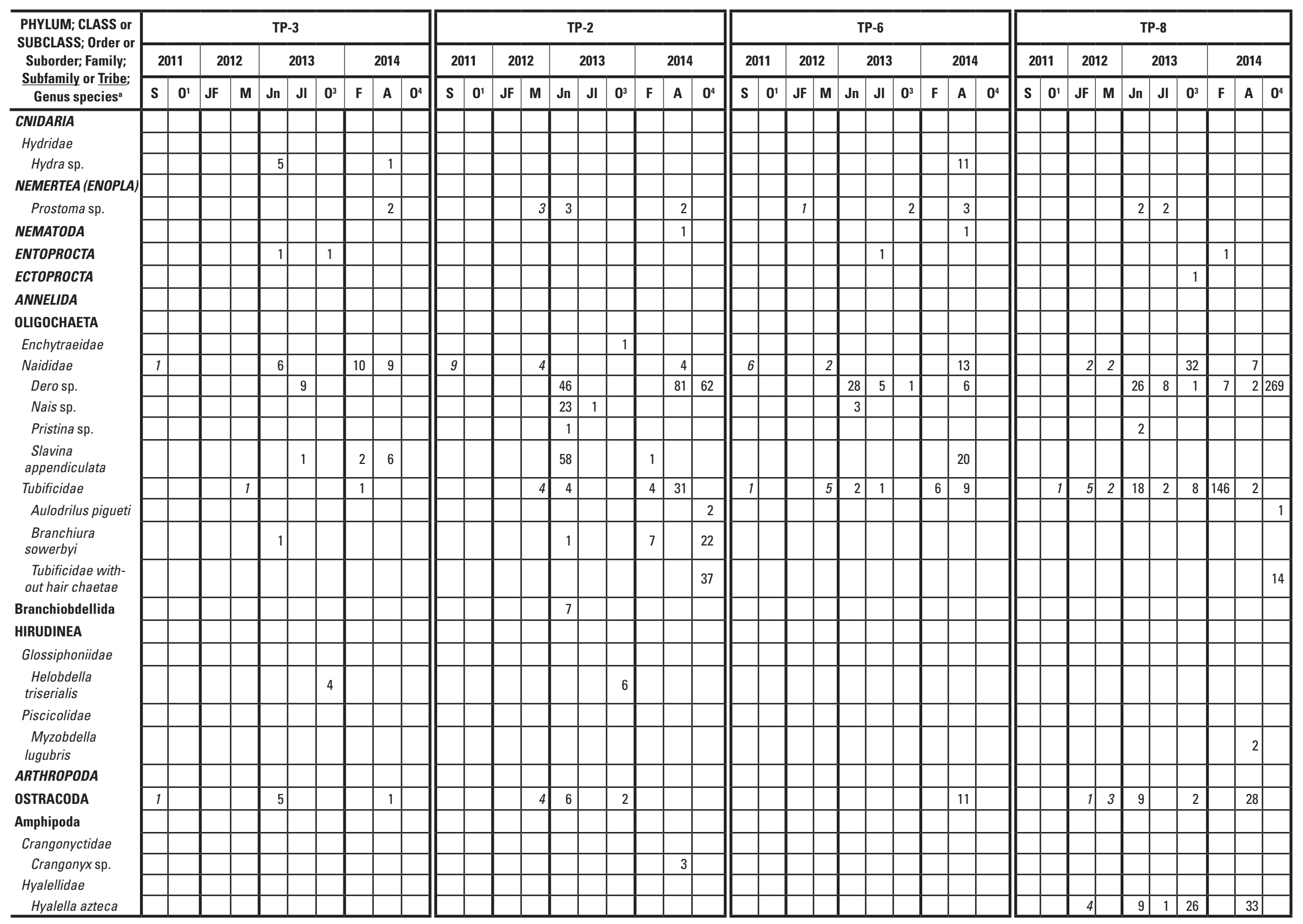


Table 12. Macroinvertebrate taxa and number of individuals collected in Topock Marsh at each sample station on each sampling date.-Continued

[TP, sampling station; S, September 2011; O', October 2011; JF, January/February 2012; M, March 2012; Jn, June 2013; Jl, July 2013; O33, October 2013; F, February 2014; A, April 2014; O4, October 2014]

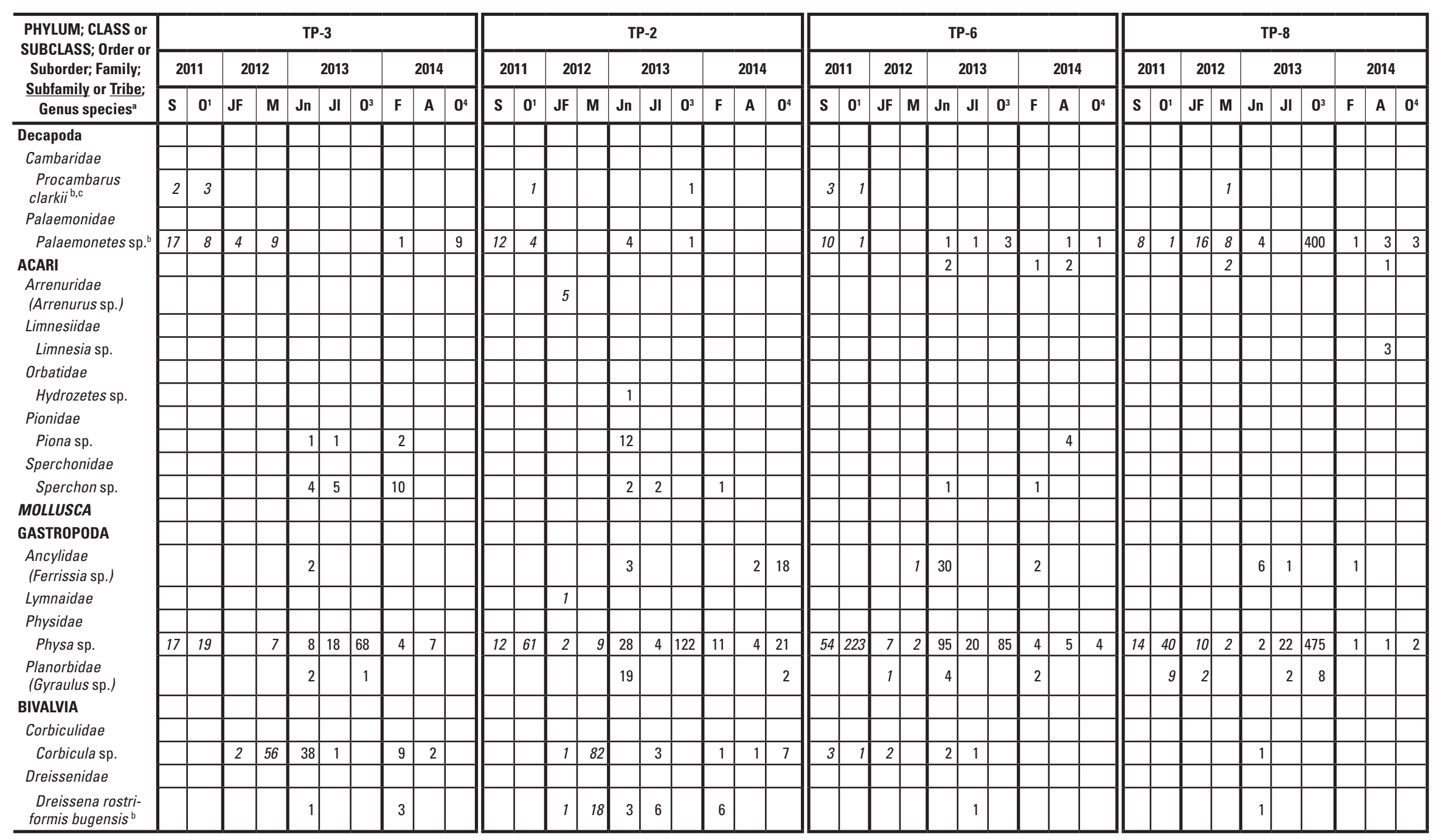


Table 12. Macroinvertebrate taxa and number of individuals collected in Topock Marsh at each sample station on each sampling date.-Continued

[TP, sampling station; S, September 2011; O', October 2011; JF, January/February 2012; M, March 2012; Jn, June 2013; Jl, July 2013; O³, October 2013; F, February 2014; A, April 2014; O4, October 2014]

\begin{tabular}{|c|c|c|c|c|c|c|c|c|c|c|c|c|c|c|c|c|c|c|c|c|c|c|c|c|c|c|c|c|c|c|c|c|c|}
\hline \multirow{3}{*}{\begin{tabular}{|c|} 
PHYLUM; CLASS or \\
SUBCLASS; Order or \\
Suborder; Family; \\
Subfamily or Tribe; \\
Genus species \\
\end{tabular}} & \multicolumn{9}{|c|}{ TP-3 } & \multicolumn{8}{|c|}{ TP-2 } & \multicolumn{8}{|c|}{ TP-6 } & \multicolumn{8}{|c|}{ TP-8 } \\
\hline & \multicolumn{2}{|c|}{2011} & \multicolumn{2}{|c|}{2012} & \multicolumn{2}{|c|}{2013} & \multicolumn{3}{|c|}{2014} & \multicolumn{2}{|c|}{2011} & 2012 & \multicolumn{2}{|c|}{2013} & \multicolumn{3}{|c|}{2014} & 2011 & \multicolumn{2}{|c|}{2012} & \multicolumn{2}{|c|}{2013} & \multicolumn{3}{|c|}{2014} & 2011 & \multicolumn{2}{|c|}{2012} & \multicolumn{2}{|c|}{2013} & \multicolumn{3}{|c|}{2014} \\
\hline & $s$ & $0^{1}$ & JF & $\mathbf{M}$ & Jn & \begin{tabular}{l|l}
$\mathbf{J I}$ & 0
\end{tabular} & $\begin{array}{l}{ }^{3} \\
F\end{array}$ & A & $0^{4}$ & $s$ & $0^{1}$ & \begin{tabular}{l|l}
$\mathbf{J F}$ & $\mathbf{M}$
\end{tabular} & Jn & \begin{tabular}{|l|l}
$\mathrm{JI}$ & $0^{3}$
\end{tabular} & \begin{tabular}{l|l}
$\mathbf{0}^{3}$ & $\mathrm{~F}$
\end{tabular} & A & $0^{4}$ & \begin{tabular}{l|l}
$\mathbf{S}$ & $\mathbf{O}^{\prime}$
\end{tabular} & \begin{tabular}{l|l|}
$\mathbf{0}^{1}$ & $\mathrm{JF}$
\end{tabular} & $\mathbf{M}$ & \begin{tabular}{|l|l|l} 
Jn & ال
\end{tabular} & $0^{3}$ & $\mathbf{F}$ & $\begin{array}{ll}\text { A } & 0\end{array}$ & $0^{4}$ & \begin{tabular}{|l|l}
$s$ & 0
\end{tabular} & \begin{tabular}{l|l}
$D^{1}$ & JF
\end{tabular} & $\begin{array}{lll} & \mathbf{J}\end{array}$ & \begin{tabular}{l|l}
$J \mathbf{J}$ & $\mathrm{J}$
\end{tabular} & \begin{tabular}{l|l} 
& $0^{3}$
\end{tabular} & $\mathbf{F}$ & A & $0^{4}$ \\
\hline \begin{tabular}{|l} 
Total number of \\
organisms by date \\
and location
\end{tabular} & 72 & 55 & 6 & 79 & \begin{tabular}{|l|l|l|}
148 & 5
\end{tabular} & \begin{tabular}{l|l}
54 & 110
\end{tabular} & $\begin{array}{l}06 \\
06\end{array}$ & \begin{tabular}{l|l}
79 & 1
\end{tabular} & 13 & 55 & 78 & \begin{tabular}{l|l}
34 & 575
\end{tabular} & 5319 & \begin{tabular}{|l|l|}
19 & 175
\end{tabular} & \begin{tabular}{l|l|l} 
&
\end{tabular} & 189 & 278 & \begin{tabular}{|l|l|l|}
211 & 261
\end{tabular} & \begin{tabular}{l|l|}
261 & 33
\end{tabular} & \begin{tabular}{|l|l|}
26 & 2
\end{tabular} & \begin{tabular}{|l|l|}
202 & 82
\end{tabular} & 121 & \begin{tabular}{|l|l|}
20 & 11
\end{tabular} & \begin{tabular}{l|l}
115 & 17
\end{tabular} & 17 & \begin{tabular}{|l|l|l}
46 & 217
\end{tabular} & $17|380|$ & \begin{tabular}{|l|l|l|}
26 & 13
\end{tabular} & \begin{tabular}{l|l}
130 & 46
\end{tabular} & \begin{tabular}{l|l}
6 & 1465
\end{tabular} & 259 & & \\
\hline $\begin{array}{l}\text { Maximum individuals } \\
\text { in a given taxa: }\end{array}$ & 17 & 19 & 4 & 56 & \begin{tabular}{|l|l}
66 & 1
\end{tabular} & \begin{tabular}{l|l}
18 & 68
\end{tabular} & 12 & 29 & 9 & 12 & 61 & \begin{tabular}{l|l}
18 & 211
\end{tabular} & 74 & \begin{tabular}{|l|l|l|}
6 & 122 \\
\end{tabular} & \begin{tabular}{|l|l|}
22 & 11
\end{tabular} & 81 & 78 & \begin{tabular}{l|l}
83 & 223
\end{tabular} & \begin{tabular}{l|l|}
223 & 8 \\
\end{tabular} & 6 & \begin{tabular}{l|l}
95 & 37 \\
\end{tabular} & 85 & \begin{tabular}{l|l}
6 & 2
\end{tabular} & $\begin{array}{ll}20 & 8\end{array}$ & 8 & \begin{tabular}{|l|l|}
14 & 108 \\
\end{tabular} & \begin{tabular}{l|l}
08 & 231
\end{tabular} & 8 & \begin{tabular}{l|l}
31 & 22 \\
\end{tabular} & 2475 & 146 & 532 & 269 \\
\hline
\end{tabular}

${ }^{a}$ The orders do not necessarily belong to the class that they are listed under.

bonnative species.

cData for P. clarkii are from crayfish traps set in 2011-2013, not from D-net sweeps.

Species richness 2011-2012: 41

Species richness 2013-2014: 72

Species richness: Total number of taxa occurring in Topock during 2011-2014 $=78$ 
Table 13. Summary of fish captured per net by Arizona Game and Fish Department using experimental gill nets each February from 2010 to 2015.

[Locations where gill nets were set are divided into five regions within Topock Marsh and illustrated in figures $25 A$ and 25B. NE, North End; FB, Fire Break Canal; BO, Beal Lake Outlet; CF, Catfish Paradise; SD, South Dike; AGFD, Arizona Game and Fish Department]

\begin{tabular}{|c|c|c|c|c|c|c|c|c|c|c|c|c|c|c|}
\hline \multirow[b]{2}{*}{ Year } & \multirow[b]{2}{*}{ Region $^{1}$} & \multirow[b]{2}{*}{$\begin{array}{c}\text { Number } \\
\text { of gill } \\
\text { nets set }\end{array}$} & \multicolumn{12}{|c|}{ Number of fish captured per net in each region ${ }^{1}$} \\
\hline & & & $\begin{array}{c}\text { Razorback } \\
\text { sucker }\end{array}$ & $\begin{array}{c}\text { Gizzard } \\
\text { shad }\end{array}$ & $\begin{array}{c}\text { Threadfin } \\
\text { shad }\end{array}$ & $\begin{array}{c}\text { Channel } \\
\text { catfish }\end{array}$ & $\begin{array}{l}\text { Yellow } \\
\text { bullhead }\end{array}$ & $\begin{array}{l}\text { Largemouth } \\
\text { bass }\end{array}$ & $\begin{array}{c}\text { Striped } \\
\text { bass }\end{array}$ & $\begin{array}{l}\text { Sunfish } \\
\text { species }^{2}\end{array}$ & $\begin{array}{c}\text { Black } \\
\text { crappie }\end{array}$ & $\begin{array}{l}\text { Carp and } \\
\text { goldfish }\end{array}$ & $\begin{array}{c}\text { Total number } \\
\text { of fish } \\
\text { in region }\end{array}$ & $\begin{array}{c}\text { Total fish } \\
\text { minus } \\
\text { gizzard shad }\end{array}$ \\
\hline 2010 & $\mathrm{NE}$ & 3 & 0.0 & 0.0 & 0.0 & 4.0 & 1.3 & 15.3 & 2.0 & 1.0 & 0.0 & 5.3 & 28.9 & 28.9 \\
\hline 2011 & $\mathrm{NE}$ & 3 & 1.7 & 0.0 & 0.3 & 4.3 & 1.0 & 10.3 & 0.0 & 0.7 & 3.0 & 2.7 & 24.0 & 24.0 \\
\hline 2012 & $\mathrm{NE}$ & 1 & 1.0 & 1.0 & 0.0 & 6.0 & 1.0 & 5.0 & 6.0 & 0.0 & 3.0 & 2.0 & 25.0 & 24.0 \\
\hline 2013 & $\mathrm{NE}$ & 1 & 0.0 & 1.0 & 0.0 & 15.0 & 4.0 & 4.0 & 0.0 & 0.0 & 2.0 & 3.0 & 29.0 & 28.0 \\
\hline 2014 & $\mathrm{NE}$ & 2 & 1.5 & 10.0 & 0.0 & 19.5 & 1.0 & 3.0 & 7.5 & 0.0 & 1.0 & 1.0 & 44.5 & 34.5 \\
\hline 2015 & $\mathrm{NE}$ & 2 & 0.0 & 36.0 & 0.5 & 4.5 & 0.0 & 0.5 & 8.5 & 0.0 & 2.0 & 1.0 & 53.0 & 17.0 \\
\hline 2010 & FB & 2 & 0.5 & 0.0 & 2.0 & 3.0 & 1.0 & 2.5 & 0.5 & 0.0 & 0.0 & 5.0 & 14.5 & 14.5 \\
\hline 2011 & FB & 2 & 0.0 & 0.0 & 0.0 & 2.5 & 2.0 & 2.0 & 0.0 & 0.5 & 3.0 & 2.5 & 12.5 & 12.5 \\
\hline 2012 & FB & 4 & 2.3 & 1.3 & 0.5 & 4.0 & 0.8 & 2.0 & 6.3 & 0.0 & 1.0 & 1.5 & 19.7 & 18.4 \\
\hline 2013 & FB & 4 & 2.5 & 1.3 & 0.0 & 12.3 & 3.0 & 3.5 & 1.3 & 0.5 & 0.8 & 4.8 & 30.0 & 28.7 \\
\hline 2014 & FB & 3 & 1.3 & 19.7 & 0.0 & 6.7 & 2.0 & 1.7 & 14.7 & 0.3 & 1.3 & 1.0 & 48.7 & 29.0 \\
\hline 2015 & FB & 2 & 0.0 & 39.5 & 0.5 & 12.0 & 3.0 & 0.0 & 17.5 & 0.0 & 0.5 & 1.0 & 74.0 & 34.5 \\
\hline 2010 & $\mathrm{BO}$ & 1 & 0.0 & 0.0 & 0.0 & 0.0 & 0.0 & 1.0 & 0.0 & 1.0 & 0.0 & 6.0 & 8.0 & 8.0 \\
\hline 2011 & $\mathrm{BO}$ & 0 & \multicolumn{12}{|c|}{ No nets set in this region } \\
\hline 2012 & $\mathrm{BO}$ & 2 & 0.0 & 0.0 & 0.0 & 0.5 & 0.0 & 1.0 & 0.0 & 1.0 & 0.5 & 3.5 & 6.5 & 6.5 \\
\hline 2013 & $\mathrm{BO}$ & 3 & 0.7 & 3.3 & 0.0 & 1.0 & 0.0 & 1.0 & 0.3 & 0.3 & 0.0 & 1.7 & 8.3 & 5.0 \\
\hline 2014 & $\mathrm{BO}$ & 2 & 0.0 & 2.5 & 0.0 & 2.0 & 1.0 & 2.5 & 0.0 & 0.5 & 0.5 & 5.0 & 14.0 & 11.5 \\
\hline 2015 & $\mathrm{BO}$ & 2 & 0.0 & 20.0 & 0.0 & 4.0 & 0.5 & 0.5 & 0.5 & 0.0 & 0.5 & 0.0 & 26.0 & 6.0 \\
\hline 2010 & $\mathrm{CF}$ & 3 & 1.3 & 0.0 & 1.7 & 2.7 & 1.0 & 5.3 & 0.0 & 2.0 & 2.7 & 11.0 & 27.7 & 27.7 \\
\hline 2011 & $\mathrm{CF}$ & 4 & 1.0 & 0.0 & 0.0 & 1.5 & 0.0 & 2.3 & 0.0 & 0.3 & 2.5 & 3.0 & 10.6 & 10.6 \\
\hline 2012 & $\mathrm{CF}$ & 2 & 1.0 & 2.0 & 0.0 & 1.0 & 0.0 & 3.5 & 1.0 & 0.0 & 3.5 & 2.0 & 14.0 & 12.0 \\
\hline 2013 & $\mathrm{CF}$ & 1 & 1.0 & 7.0 & 0.0 & 3.0 & 3.0 & 1.0 & 0.0 & 0.0 & 1.0 & 1.0 & 17.0 & 10.0 \\
\hline 2014 & $\mathrm{CF}$ & 2 & 1.5 & 21.5 & 0.0 & 6.5 & 0.0 & 1.5 & 0.0 & 0.0 & 1.0 & 2.0 & 34.0 & 12.5 \\
\hline 2015 & $\mathrm{CF}$ & 2 & 0.0 & 9.5 & 0.0 & 11.0 & 1.0 & 2.0 & 0.0 & 1.5 & 1.0 & 1.0 & 27.0 & 17.5 \\
\hline 2010 & SD & 1 & 8.0 & 0.0 & 0.0 & 3.0 & 0.0 & 1.0 & 0.0 & 2.0 & 5.0 & 21.0 & 40.0 & 40.0 \\
\hline 2011 & SD & 1 & 8.0 & 0.0 & 1.0 & 1.0 & 0.0 & 2.0 & 1.0 & 0.0 & 0.0 & 5.0 & 18.0 & 18.0 \\
\hline 2012 & SD & 1 & 10.0 & 6.0 & 0.0 & 1.0 & 0.0 & 1.0 & 11.0 & 0.0 & 3.0 & 3.0 & 35.0 & 29.0 \\
\hline 2013 & SD & 1 & 2.0 & 1.0 & 0.0 & 2.0 & 0.0 & 0.0 & 0.0 & 0.0 & 2.0 & 0.0 & 7.0 & 6.0 \\
\hline 2014 & SD & 1 & 4.0 & 38.0 & 0.0 & 5.0 & 1.0 & 4.0 & 0.0 & 0.0 & 0.0 & 2.0 & 54.0 & 16.0 \\
\hline 2015 & SD & 1 & 0.0 & 36.0 & 11.0 & 7.0 & 0.0 & 3.0 & 2.0 & 0.0 & 2.0 & 0.0 & 61.0 & 25.0 \\
\hline
\end{tabular}

${ }^{1}$ Regions where AGFD set gill nets in Topock Marsh: NE = North End ; FB = Fire Break Canal; BO = Beal Lake Outlet; $\mathrm{CF}=\mathrm{Catfish}$ Paradise; SD = South Dike

${ }^{2}$ Sunfish species included bluegill, green sunfish, and redear. 
$114^{\circ} 32^{\prime}$

$114^{\circ} 31^{\prime}$

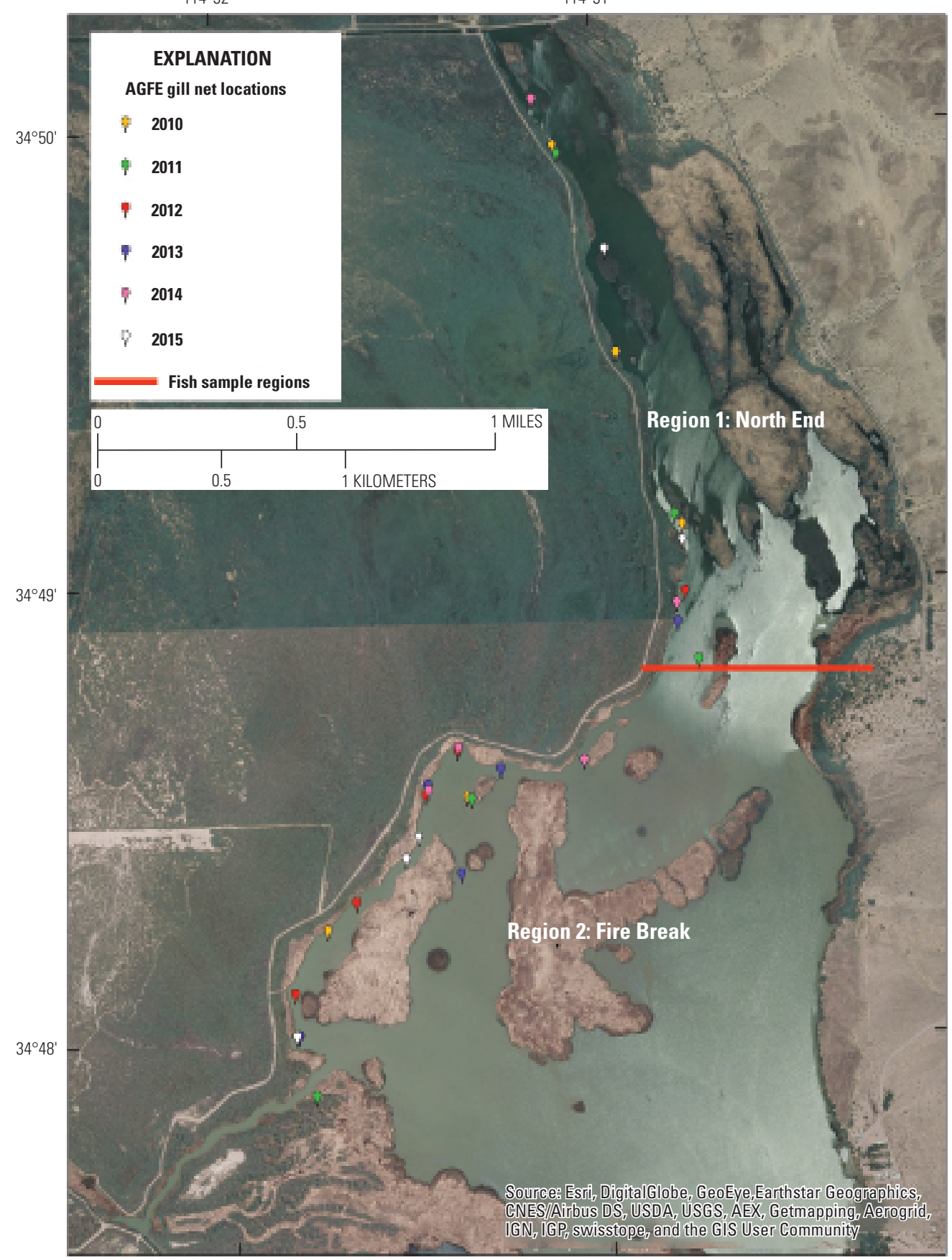

Figure 25A. Northern portion of Topock Marsh showing Arizona Game and Fish Department's (AGFD's) gill net locations, 2010-2015. (See table 13 for fish numbers captured per net in each region by year). 


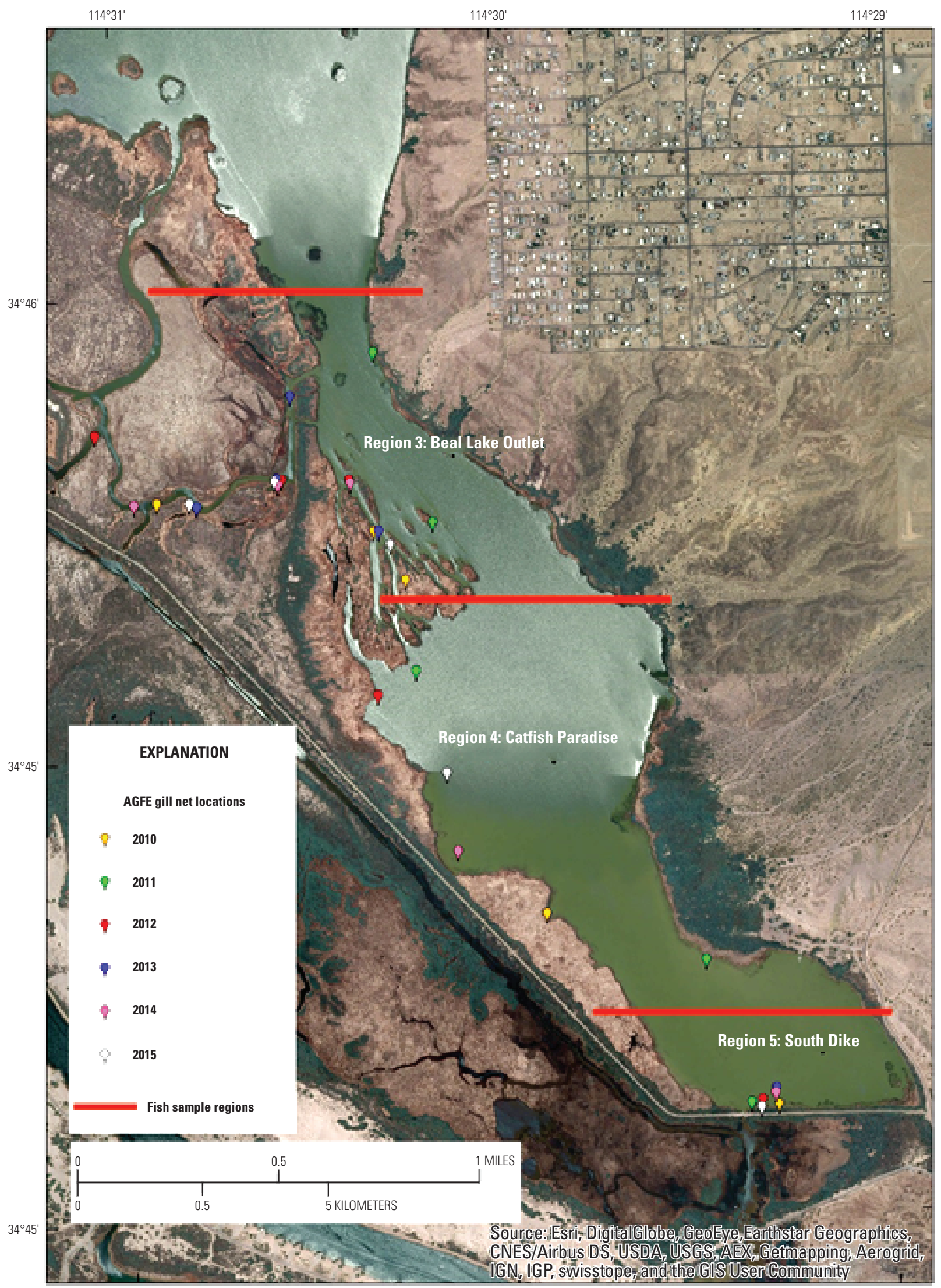

Figure 25B. Southern portion of Topock Marsh showing AGFD's gill net locations, 2010-2015. (See table 13 for fish numbers captured per net in each region by year). 


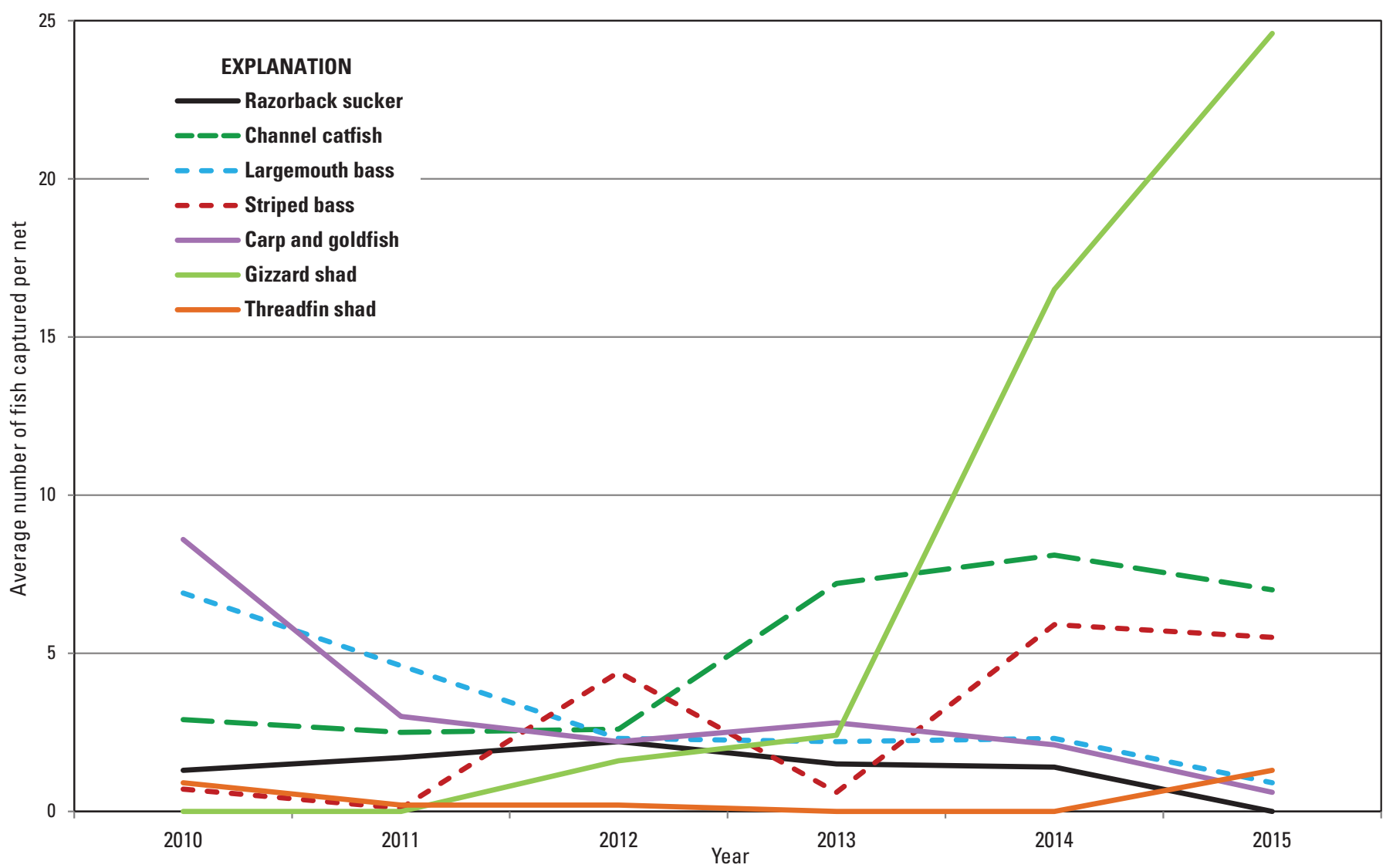

Figure 26. Average number of fish captured per gill net per year in Topock Marsh by species. Data were provided by Arizona Game and Fish Department.

\section{Discussion}

The central question throughout this study was how do waterflows, water conditions, and the Havasu NWR's associated water management decisions affect multiple indicators of ecological conditions and ecological change in the Topock Marsh ecosystem? For the initial 2011-12 investigation, the marsh was evaluated under low waterflow conditions. For 2013-14, the marsh was evaluated under higher waterflow conditions. This report discusses the study's findings, and tries to relate various components and describe potential mechanisms. Detailed data summarized within this report are available in the Topock Marsh Water and Resource Management DSS for use as Excel spreadsheets that provide specific biotic and abiotic information under low and high hydrologic conditions (Holmquist-Johnson and others, 2016).

\section{Water-Quality Characteristics}

\section{Physicochemistry}

By recording depth profiles (figs. 4, 6, 8, 10, and 13) and diurnal tracks (figs. 5, 7, 9, 11, and 14) of various parameters from each of the 4 sampling stations in Topock Marsh during
11 sampling dates, a wide range of seasonal data have been accumulated. Much of this physicochemistry data followed well-defined seasonal, daily, and (or) spatial patterns. However, other data were directly related to waterflow and elevation effects.

Water temperature extremes ranging from a high of $35.8^{\circ} \mathrm{C}$ $\left(96.4^{\circ} \mathrm{F}\right)$ to a low of $5.2^{\circ} \mathrm{C}\left(41.4^{\circ} \mathrm{F}\right)$ (fig. 4) during the sampling trips were indicative of seasonal patterns. Water temperatures at the surface during September 2011, June and July 2013, April 2014, and September 2014, dropped with depth at TP-2 (figs. $4 A b$ and $4 B b$ ), showing evidence of colder Colorado River water entering the marsh at that location. For comparison, temperatures on the river downstream of Needles Bridge averaged $20.9^{\circ} \mathrm{C}$ $\left(69.6^{\circ} \mathrm{F}\right.$ ) during the 2013 summer (Scott O’Meara, Bureau of Reclamation, unpub. data, 2014). Cooler months did not have as large a temperature difference between the marsh and the river, and inflow from the Fire Break Canal was minimal during the winter months, so the mixture of marsh and river water was less evident (fig. 2A).

Diurnal water temperature fluctuations followed normal well-defined seasonal, daily, and spatial patterns as well. As with the depth profile data, the lower diurnal water temperatures at TP-2 indicated cooler Colorado River water entering the marsh at that location during the warmer months of 2013 and 2014 (fig. 5B). 
Specific conductivity values and their variation during the study period, in addition to the variations in water temperature, provide clues as to what was happening within Topock Marsh in response to different waterflow conditions. During the initial sampling trip (July 2011), SC within Topock Marsh was highest at TP-3 and TP-2, the most upstream sampling stations, and lowest at TP-8 (figs. $6 A$ and $7 A$ ). However, by September 2011, SC concentrations at TP-3 and TP-2 decreased substantially compared to the July 2011 values (fig. $7 A$ ) and concentrations at TP-8 increased (fig. 6Ad). The differences most likely were due to the influence of Colorado River water entering the marsh during September, and again later in October, from the Fire Break Canal (fig. 2A). Likewise, during the February 1, 2012, sampling event, river water with lower SC was flowing in from all three inlets: Inlet Canal, Fire Break Canal, and Farm Ditch Canal (fig. 2A). At TP-2, the deepest sampling station, the warmer river water flowed past our sampling station near the surface and the cooler marsh water containing higher $\mathrm{SC}$ concentrations remained nearer to the marsh floor (fig. $6 \mathrm{Ab}$ ). However, after $1 \frac{1}{2}$ months of constant daily inflow from the Topock Inlet and Fire Break Canals and very strong winds between January and March (up to $91.1 \mathrm{~km} / \mathrm{h}(56.0 \mathrm{mi} / \mathrm{h}$ ) on March 6) (fig. $3 B$ ), the water chemistry in March was thoroughly mixed throughout the water column at both TP-3 and TP-2 and SCs at those locations were very similar (figs. $6 A a, 6 A b$ and $7 A$ ).

The pattern of spatial variability in SC within the marsh during 2013 and 2014 differed from the 2011-12 sampling period because of the more consistent inflow from the Colorado River through the Fire Break Canal and the closure of the Inlet Canal (fig. $2 A$ ). Temperature depth profiles confirmed that cooler, fresher water entered the marsh near TP-2 and slightly lowered SC values during June and July 2013 and April 2014 (fig. $6 B b$ ). The diurnal tracks in figure 7 illustrate how SC decreased from $0.076 \mathrm{~m}^{3} / \mathrm{s}\left(2.7 \mathrm{ft}^{3} / \mathrm{s}\right)$ to $0.368 \mathrm{~m}^{3} / \mathrm{s}\left(13 \mathrm{ft}^{3} / \mathrm{s}\right)$ as inflow ramped up during the February 2014 sampling week. By mid-March 2014, Fire Break Canal inflows were consistently maintained above $2.0 \mathrm{~m}^{3} / \mathrm{s}\left(70 \mathrm{ft}^{3} / \mathrm{s}\right)$ and these inflows continued through the April 2014 sampling trip. Not only did these inflows freshen the water at TP-2, but they appear to have freshened the water as far upstream as TP-3 (fig. $7 B$ ) as indicated by the decreasing SC concentrations (table 4 and fig. 6Ba). Likewise, inflow through the Farm Ditch Canal helped freshen water at TP-6 (fig. 6Bc). Water at TP-8 was not affected by the fresher water by April 2014, but by the September/October 2014 sampling trip, the SC decreased from an average of $2,020 \mu \mathrm{S} / \mathrm{cm}$ (1,295 ppm) to $1,810 \mu \mathrm{S} / \mathrm{cm}(1,160 \mathrm{ppm})$ (fig. $6 B d$ ).

October $\mathrm{pH}$ values recorded at TP-6 and TP-8 in 2011, and at all four sampling stations in 2013 and 2014, were consistently higher than those recorded during the other sampling periods as shown by the depth profiles (fig. 8) and diurnal fluctuation graphs (fig. 9). The higher values and larger fluctuations in $\mathrm{pH}$ during 2013 and 2014 were especially pronounced and were most likely due to diurnal dynamics in photosynthesis and respiration by the dense SAV (Cronk and Fennessy, 2001; Kadlec and Wallace, 2009) at TP-3 and TP-6 (fig. $9 B$ ) and the high density and biovolume of phytoplankton (fig. 23) at TP-8. Inversely, $\mathrm{pH}$ values were lower throughout the marsh in February 2014 (fig. 9) when virtually no SAV and somewhat less phytoplankton was present. Similar seasonal shifts in $\mathrm{pH}$ reported by Guay (2001) were also likely due to the seasonal changes in SAV. Otherwise, $\mathrm{pH}$ ranged from 7.58 to 9.08 throughout the study period.

Dissolved oxygen concentrations varied temporally, seasonally, and spatially within the marsh (fig. 10). Observed diurnal variation (fig. 11) was most likely due to oxygen production during photosynthesis by the SAV and phytoplankton during daylight, and the lack of photosynthesis at night (Reddy and DeLaune, 2008). Plant coverage was denser in September and October every year, so DO swings tended to be larger during that time. Additionally, DO concentrations at all locations were higher during the cooler months of December through March each year (fig. 3), thus illustrating the typical inverse relationship between DO and temperature (Kadlec and Wallace, 2009). Differences in DO between the sampling stations are most likely due to variations in plant and phytoplankton densities, wind patterns, and proximity to the inflow of fresh Colorado River water (Chui and Jirka, 2003). In fact, diurnal swings in DO at TP-2 were smaller than at other sites, which is likely due to the $2.5-\mathrm{m}(8.2-\mathrm{ft})$ deep channel at that sampling location not being conducive to SAV growth. However, the increasing DO values at TP-2, recorded by the MiniSonde units deployed at the site (fig. 11) during April and September/October 2014 were unexpected. It is possible the DO probes on the MiniSonde units malfunctioned, even though they were different units each time and both units were calibrated prior to deployment. Water inflow was high during the April 2014 sampling trip (an average of $3.52 \mathrm{~m}^{3} / \mathrm{s}\left[124.18 \mathrm{ft}^{3} / \mathrm{s}\right]$ ), but was not as high during the September/October 2014 sampling trip (an average of $0.889 \mathrm{~m}^{3} / \mathrm{s}\left[31.37 \mathrm{ft}^{3} / \mathrm{s}\right]$ ). The most important conclusion regarding DO within Topock Marsh is that all locations had DO concentrations well above the minimum threshold of $3.0 \mathrm{mg} / \mathrm{L}$, which is established as the one-day criteria for "other life stages" of warm water fish by the U.S. Environmental Protection Agency (1986a).

Water clarity varied spatially, most likely because of local differences in water depth, sediment texture, SAV abundance, and disturbance of the underlying sediments from wind, fish, birds, or motor boat activity (tables 4 and 6; and figs. 12, 13, and 14). Of course, most of these influences were seasonal as well. TP-8 is located near the end of the marsh in an area that is very exposed to winds and motor boat traffic and is used by abundant wildlife (fish and waterfowl), which stir up the sediments and add to the nutrient load (Andersen and others, 2003). As further evidence of the turbid conditions, TSS concentrations were consistently higher (table 4 ) and Secchi disk readings were consistently lower (fig. 13) at TP-8 compared to the other sites throughout 2013 and 2014. Examining the water-quality data throughout the sampling periods, samples collected in 2011-12 lead us to conclude that much of the turbidity throughout the marsh was due to the suspension of the autochthonous sediment. This conclusion, which is based in part on the lower percentage 
organic $\mathrm{N}$ to total nitrogen concentrations (table 4 ) and the "very heavy sediment" comment by the phytoplankton technician in regards to the 2012 samples from TP-6, corroborates Guay's (2001) findings. In 2013 and 2014, on the other hand, samples collected at TP-8 contained high chlorophyll $a$ concentrations (fig. 15), high phytoplankton densities and biovolumes (fig. 23) and high organic-N concentrations. Thus, we conclude that, in 2013 and 2014, dense phytoplankton was primarily responsible for the higher turbidity at TP-8.

Inversely, turbidity was lower and water clarity was higher at the upstream stations in 2013-14. Turbidity values were lower at TP-2 (fig. 12), where fresh Colorado River water enters one of the deepest sections of the marsh through a concrete-lined canal, and at TP-3 and TP-6, where dense SAV was present to trap suspended sediments and hold the soft loamy sand, clay loam, and silty clay loam substrate in place (table 6). Alanen (1998) observed that, in general, areas in Topock Marsh that had the lowest turbidity were associated with high SAV coverage, and areas with high turbidity contained less SAV coverage. However, Alanen (1998) reported much lower mean turbidity values than the values reported in this report. Alanen reported yearly grand means of 9.5 and 18.4 NTUs for 1996 and 1997, respectively, compared to our yearly grand means throughout the marsh that ranged between 39.3 and 62.4 NTUs (table 4 , surface turbidity values). The highest turbidity Alanen reported was 29.9 NTUs, which was measured in the Upper Goose Lake, the open area between TP-1 and TP-7. Guay (2001) found turbid conditions ranging between 20 and 50 NTUs and averaging about 25 NTUs; this value is 36 percent lower than our lowest yearly mean results.

\section{Chlorophyll $a$, Nutrients, Major lons, and Trace Elements}

During low-flow conditions in July 2011, chlorophyll $a$ concentrations were moderately high throughout Topock Marsh; however, once inflow resumed from the Colorado River, water containing lower chlorophyll $a$ concentrations pushed the higher concentrations downstream where they concentrated at TP-8, the most downstream sampling station. Following the completion of the Fire Break Canal in January 2012, the lowest chlorophyll $a$ concentrations consistently occurred at TP-2, but one notable exception occurred in September/October 2014 at TP-6 where spiny naiad was very dense (table 12) and water clarity was the greatest (fig. 13).

Mirroring the downstream movement of the chlorophyll $a$ concentrations, surface water samples from TP-8 consistently contained at least twice the TN, Org-N, and TP concentrations as the other sampling stations (fig. 16). The high average percentage of Org-N to TN ( $>80$ percent) throughout the 4 years of sampling (table 4), and even higher percentages throughout the springs and summers ( $\geq 92$ percent), provides evidence that the majority of TN was likely due to the phytoplankton in the water column (See figs. 15 and 23 and the Phytoplankton, Zooplankton, and Aquatic Macroinvertebrates section of this report for more information.). Likewise, lower percentages of Org-N to TN measured at TP-2 likely were due to relatively less phytoplankton in the fresh water inflow from the Colorado River, which contained higher mean concentrations of inorganic nitrogen $(0.35 \mathrm{mg} / \mathrm{L})$ (Scott O'Meara, Bureau of Reclamation, unpub. data, 2014).

Stiff diagrams for 2011 (fig. 17), 2013 (fig. 18), and 2014 (fig. 19) were used to compare the ionic composition of the water from the four sampling stations and the Colorado River water (inset in diagram $B$. on figs. 18 and 19) through time. Water at TP-2 was clearly the most similar to the river water during each year (figs. 17, 18, and 19). Water at TP-8, the furthest sampling station downstream of the Fire Break Canal and the Farm Ditch Canal, was the least similar to river water in 2013 and 2014. Thus, these diagrams illustrate the gradual change in ionic composition as the water moved further downstream and away from where the river water entered the marsh.

Results of analyses for elements of concern are listed in table 5. Most values during 2013-14 were similar to, or less than, 2011 values, presumably due to dilution from the additional waterflow in 2013-14. The exceptions are mean As concentrations in both 2013 and 2014 and Mn concentrations in 2014 at TP-8, which were higher than in previous years. In fact, concentrations of $\mathrm{As}, \mathrm{B}, \mathrm{Cr}$, fluoride, $\mathrm{Fe}, \mathrm{Mn}$, and lead were higher at TP-8 than at the other sampling stations because dissolved elements concentrated at the terminus of the system. The replicate samples collected from TP- 6 contained markedly lower concentrations of $\mathrm{Fe}, \mathrm{Mn}$, lead, and Se during September/October 2014. SAV was so dense at TP-6 in fall 2014 that it is likely that plants played a role in decreasing elemental concentrations by taking up more elements and (or) providing a filtering mechanism that allowed dissolved solids to fall out of the water column into the sediment below (Cronk and Fennessy, 2001). Note the lower TSS concentrations (table 4) at TP-6 throughout the study period. Concentrations of elements of concern for wildlife (that is, $\mathrm{As}, \mathrm{Hg}$, Se, and $\mathrm{Cr}$ ) in water samples were below State and Federal toxicity standards (table 5) (Eisler, 1988; Arizona Department of Environmental Quality [ADEQ], 2009) for aquatic wildlife.

\section{Long-Term Water Chemistry}

An informal review of the long-term water chemistry data displayed in appendix 1 indicates that the values observed during the study period were not unusual. There was a fairly consistent trend in SC from 1983 to April 2015 of the measured parameters peaking during the winter prior to spring water releases from Davis Dam (fig. 20). Between June 1994 and June 2003, fewer extremes (highs and lows) were recorded, but the SC extremes resumed in late 2003 when SC generally increased through January 2011 (fig. 20) as Guay (2001) predicted if water management remained the same. After the Fire Break Canal became operational, average SC values in the marsh were only slightly higher (1.12 times) than values reported by Guay (2001) for 1995-1998. In fact, SC decreased overall within the marsh from $2,237 \mu \mathrm{S} / \mathrm{cm}(1,434 \mathrm{ppm})$ in 
January 2012 to $1,937 \mu \mathrm{S} / \mathrm{cm}(1,242 \mathrm{ppm})$ in January 2015 (app. 1 and fig. 20). Water-quality monitoring would need to be continued to verify this trend. These data, and all the historical water chemistry data, provide valuable information to help predict future water quality and wildlife habitat changes caused by various water management scenarios, which are in turn tied to the capacity of the Havasu NWR's waterrelated infrastructure.

\section{Sediment Chemistry}

A great deal of variation was found among sediment collected from the four sampling stations in 2011, 2013, and 2014 (table 6). However, variations were not unexpected since soil texture, water chemistry, and the presence or absence of vegetation differed between sampling locations, as well as between seasons. Although these results represent a wide variation in sediments throughout the marsh, no potential problems or toxicity issues were noted, with the exception of a slightly elevated As concentration at TP-2 in October 2014. However, there were no signs of bioaccumulation evident during the study, and the remaining samples contained concentrations of As, $\mathrm{Cr}, \mathrm{Hg}$, and Se below established threshold effects for wildlife (MacDonald and others, 2000; Lemly, 2002).

Alanen (1998) assumed that nutrients in the water were less important to spiny naiad growth than nutrients in the sediment because the roots of this plant comprise an unusually large proportion (30 percent) of total plant weight (Waisel and Agami, 1983). Although rooted, submerged plants can take up DO, carbon dioxide, and micronutrients from the water column, the majority of nutrients are acquired from the sediment (Barko and Smart, 1981; Cronk and Fennessy, 2001). Ammonium nitrogen and nitrate nitrogen concentrations in the sediments produced by decomposer microbes from senesced plant litter may be most important to aquatic plant productivity, as microbes decompose the plant litter annually (Vymazal, 1995). It was determined that sediment nutrients were highest at TP- 6 where SAV coverage was also highest on all sampling occasions (tables 6 and 8).

\section{Plant Chemistry}

Chemical analyses of California bulrush collected at each sampling station in July 2013, and of spiny naiad and Eurasian watermilfoil collected in October 2014, indicated large variations between plant species and seasons (table 7), so direct analytical comparisons between the two sampling events are not appropriate. The culms (specialized stems) of California bulrush, an emergent plant rooted in the soil, stand upright and thus contain lignin for aerial support. The submerged plants, spiny naiad and Eurasian watermilfoil, are also rooted in the soil but their stems and leaves are soft (lacking lignin) and they spend their entire life cycle under water (Cronk and Fennessy, 2001). Hence, because of their differing morphologies, the chemical makeup of the plant types is different. In addition, the chemical makeup of these plants in summer would be different from that in the fall when plants generally contain more nutrients in their storage tissues (Salisbury and Ross, 1969). The differences in the concentration of some elements in the same plant species between sampling stations may have been due to variations in the sediment or water chemistry, or possibly to the sites' proximity to Colorado River influxes. For example, aluminum, $\mathrm{Cu}$, and $\mathrm{Fe}$ concentrations were higher in plant material collected near TP-2 than in the plant material collected at the other locations. Suspension solids and algae in the water column can settle out and accumulate on leaf surfaces of SAV and be collected along with the vegetation for analyses, even with careful rinsing, thus, increasing the amount of nutrients and (or) other elements found (Vymazal, 1995; Kabata-Pendias and Pendias, 2001). Upright culms do not accumulate as much inorganic or organic material through settling of solids and algae. Even with these differences, it is interesting to note the variation between the emergent and submerged plants and to compare the chemical makeup between sampling stations. The most notable conclusion from the plant chemistry data is that concentrations of As, $\mathrm{Cr}, \mathrm{Hg}$, and Se were all below established threshold effects on wildlife (MacDonald and others, 2000; Lemly, 2002; ADEQ, 2009).

\section{Biological Characteristics}

\section{Aquatic Vegetation}

The predominant SAV in Topock Marsh during the 201114 study period was spiny naiad with smaller quantities and occurrences of sago pondweed. The study found that temperature affected the coverage success of the species (for example, virtually no SAV was observed from January to March). In addition, turbidity and water depth were important in explaining their coverage success (fig. 22), and both species achieved maximum coverage during October each year (table 8). Spiny naiad was particularly abundant in shallow water $(0.60-0.76 \mathrm{~m}$ [2.0-2.5 ft] depth) and somewhat protected areas where water clarity was relatively high (such as, turbidity $\leq 39$ NTUs).

Sago pondweed occurred in low to moderate amounts in clear, typically shallower areas $(0.30-0.46 \mathrm{~m}[1.0-1.5 \mathrm{ft}]$ depth). The microalgae, chara, occurred infrequently during this time and in small assemblages throughout the marsh (table 8).

Eurasian watermilfoil, an invasive SAV, was first noted in early 2012 near TP-2 at the mouth of the Fire Break Canal. By October 2014, it was well established and thriving around that same location, as well as where Colorado River water enters the marsh through the Farm Ditch Canal (fig. 1). Because Eurasian watermilfoil has been common in the Colorado River for a number of years (U.S. Geological Survey, 2016c), it was not unexpected to see the plant in Topock Marsh once Fire Break Canal created a new connection directly from the river.

SAV was abundant in shallow, protected areas in 2011, but very little SAV was observed during 2011-12 in the shallow, exposed areas in the center of the marsh (that is, 
the areas between TP- 1 and TP-7 and east of both TP- 5 and TP-6) (fig. 1). During that period, it was evident that winds had stirred up sediments through wave action, causing highly turbid conditions in the shallow, exposed areas that could otherwise support SAV. Guay (2001) reported similar observations and concluded that Topock Marsh was generally too turbid for submerged plant growth (Vymazal, 1995). Alanen (1998) agreed, stating that light availability, as a function of turbidity, seemed to have the greatest influence on SAV distribution and abundance. Hence, both Guay (2001) and Alanen (1998) concluded that light availability was probably the limiting factor controlling SAV distribution in the marsh. During our subsequent sampling in 2013 and 2014, we found that SAV abundance was higher when turbidity was lower. Therefore, based on our work in Topock Marsh (fig. 22 and table 8), published literature (Sand-Jensen and Borum, 1991; Cronk and Fennessy, 2001), and personal observations at other turbid southwestern United States' wetland systems, we agree with Guay's (2001) and Alanen's (1998) conclusion.

Assuming that light availability through the water column and water depth are related, Alanen (1998) further predicted that SAV biomass would be more abundant during the growing season if water levels were kept below a maximum target WSE of $139.14 \mathrm{~m}(456.5 \mathrm{ft})$ until April of each year. However, water depth alone does not control turbidity. In fact, WSEs were below $139.14 \mathrm{~m}(456.5 \mathrm{ft})$ by as much as $0.396 \mathrm{~m}(1.3 \mathrm{ft})$ in 2011 and $0.152 \mathrm{~m}(0.5 \mathrm{ft})$ in 2012 (fig. $2 B$ ). In addition, SAV was observed in 2011 only in protected areas where the shallow water was clear. Thus, we suggest that wind exposure is also a significant influence to turbidity at Topock Marsh.

Water depths continued to stay well below the $139.14 \mathrm{~m}$ (456.5 ft) WSE through 2013 and most of April 2014. Once the water elevation was raised to $139.14 \mathrm{~m}$ (456.5 ft) on April 28, 2014, it was kept at that approximate depth through May 26, 2014, to provide nesting habitat for Southwestern willow flycatchers (McLeod and Pellegrini, 2013). Subsequently, water levels were slowly lowered to the eventual winter low of $138.34 \mathrm{~m}$ (453.87 ft) (fig.2B). Turbidity measurements during the time of higher water depths, which were lower than those in 2011, improved the light penetration into the marsh and allowed more SAV coverage during the fall (tables 8 and 9). This was most likely because the deeper water prevented high winds from stirring up loose sediments from the marsh bottom and dispersing them into the water column.

Considering the critical role light plays on submerged plants (Cronk and Fennessy, 2001), turbidity was measured at the same locations as SAV coverage in 2012, 2013, and 2014. Because of the high turbidity observed in March 2012, it was expected that SAV growth would be sparse the following summer and large areas throughout the marsh would be unvegetated. However, higher water elevations later in 2012, and again in 2013 and 2014, may have caused turbidity levels in 2013-14 to be lower than in 2011 and early 2012, and better water clarity and ample light penetration encouraged abundant SAV growth (Sand-Jensen and Borum, 1991; Cronk and
Fennessy, 2001). If water quality conditions and water depths in the future remain similar to conditions in 2013-14, it is likely the SAV will continue to proliferate in areas conducive for its growth. With that said, even with higher water elevations, we have shown that dense phytoplankton can cause water clarity problems. The highest algal biovolumes occurred at times when waterflow was either very low or predominantly stagnant. Because no outflow occurred throughout the duration of this 4-year study, nutrients, solutes, phytoplankton, zooplankton, and even macroinvertebrates continued to accumulate and concentrate at TP-8 as water evaporated in what was essentially a large evaporation pond in the downstream end of the marsh. To lower the incidence of phytoplankton blooms, a water management scenario that includes regular water flushing or flow-through may be key.

This study attempted to quantitatively measure actual SAV coverage across the 1,637-hectare (4,045-acre) wetland. After training the CSU land cover model to predict the various plant species, the model predicted the total area covered by SAV to be $1.536 \mathrm{~km}^{2}$ (379.6 acres) in 2014 (Young and others, 2015). However, based on the hundreds of bathymetric points collected by the USGS team and the recording of the aquatic vegetation species and their abundance throughout the marsh, we believe this is an overestimate of the actual coverage by as much as two times. There were many locations along the October 2014 plant survey transects where SAV was not seen, yet the model predicted it to be there. Even so, the model was able to accurately predict areas where dense SAV grew in October 2014, as well as areas where dense SAV did not grow. The dead, standing mesquite trees that cover large swaths of the marsh and the across-the-board association of predicted SAV with edges of emergent vegetation may have contributed to the overestimation of the SAV. By collecting SAV coverage data along transects during different seasons, it became clear that dense SAV coverage and biomass occur during the fall each year. Although we attempted to quantify the area covered by species using the CSU land cover model (Young and others, 2015), the technology is not yet able to do it accurately. Hopefully, as the technology and imagery through turbid waters improve, SAV will eventually be accurately mapped.

In addition, the CSU land cover model did not accurately predict the correct emergent vegetation species. Even so, based on the hundreds of bathymetric points collected by the USGS team and the recording of the emergent vegetation species and their abundance throughout the marsh, it was determined that the model fairly accurately predicted the total of all emergent species as $10.662 \mathrm{~km}^{2}(2,634.6$ acres) (Young and others, 2015). Thus, the model's prediction of area covered by the combination of California bulrush and cattail, plus several minor emergent species, was fairly accurate.

As noted in the Emergent Aquatic Vegetation section under Results, Biological Characteristics, Aquatic Vegetation, it was observed during the low water, high summer temperature conditions of 2011 that cattail plants turned brown in many areas as their roots and rhizomes were exposed $30 \mathrm{~cm}$ (12 in.) or more above the waterline and California bulrush 
grew further out into deeper water. Both these plants are obligate wetland species and, so, are adapted to withstand variable wetland conditions (Cronk and Fennessy, 2001). As water levels resumed to more normal conditions, cattails recovered and thrived and the already established California bulrush continued to thrive in deeper water through the study period. Thus, the low water conditions that occurred between 2011 and early 2012 did not appear to harm the emergent plants.

\section{Phytoplankton, Zooplankton, and Aquatic Macroinvertebrates}

The results of the study show that Topock Marsh supported rich phytoplankton, zooplankton, and aquatic macroinvertebrate communities throughout 2011-14. In addition, their numbers and growth cycles showed spatial, as well as seasonal, variations.

During the low water conditions of 2011, phytoplankton species richness reached 193 individual taxa (table 10), but cell densities were relatively low except for a small blue-green algae bloom in October at TP-8 (fig. 23A). However, even though phytoplankton cell numbers remained low, the biovolume of diatom cells was high in February and March 2012 at TP-6. During that time, turbidity had also increased. Rather than assuming the turbidity was governed strictly by suspended sediments noted at that time, it appears that the diatom bloom also contributed to turbidity.

Total density and biovolumes of phytoplankton were much higher at TP-8, the most downstream sampling station, than at the upstream sampling stations in June, July, and October 2014 (fig. 23). As discussed in the Physicochemistry section under Results, Water Quality Characteristics, waterflow moved southward as evidenced by the higher SC moving downstream with higher waterflows, and solutes and nutrients concentrated at the downstream end of the marsh (tables 4 and 5, fig. 16). Thus, those higher nutrients became available to support additional phytoplankton growth (Vymazal, 1995) at TP-8, particularly during warmer temperatures.

We noted that peak air and water temperatures occurred between June and July 2013 (figs. $3 A$ and $4 B$ ). The water temperature stratification observed in July 2013 at TP-8 (fig. $4 B d$ ) corresponded to the highest levels of cell density and biovolume of phytoplankton collected during this study (fig. 23). These observations suggest that the combination of the warmer temperatures and higher nutrient concentrations triggered greater phytoplankton growth (Vymazal, 1995). Meanwhile, the relatively higher pH (fig. $8 B d$ ) and DO (fig. 10Bd) values within the stratified layer suggest greater photosynthesis occurring with the larger biovolume (Cronk and Fennessy, 2001). TP-8 contained the highest chlorophyll $a$ concentrations (fig. 15) and greatest phytoplankton biovolumes (fig. 23B) in 2013 and 2014, with little evidence of inorganic particles in the water column. Therefore, we conclude that phytoplankton was primarily responsible for higher turbidities at TP-8 in 2013 and 2014 (fig. 13Bd).
Most noteworthy among the 240 phytoplankton taxa collected in Topock Marsh during the 4-year sampling period were the blue-green algae, because many produce toxins that are dangerous to birds, wildlife, and humans (U.S. Geological Survey, 1999; Lopez and others, 2008). As suggested in ADEQ (2009), the maximum threshold criterion in warm water lakes designated for aquatic and wildlife use is 50 percent of the number of blue-green algal cells divided by the total phytoplankton cell count. This threshold was exceeded in October 2011 when blue-green algae made up 55 percent and 75 percent of the phytoplankton cell densities at TP-2 and TP-8, respectively, and in July 2013 when blue-green algae made up 66 percent and 77 percent of the phytoplankton cell densities at TP-6 and TP-8, respectively (fig. 23A). Even so, the species of blue-green algae known to produce virulent toxins (that is, Microcystis aeruginosa and Aphanizomenon flos-aquae) (Vymazal, 1995) made up only 24 percent of all blue-greens at TP-8 in October 2011, and 36 percent and 14 percent of all blue-greens in July 2013 at TP-6 and TP-8, respectively. In addition, although blue-green algae was common throughout Topock Marsh during 2013-14, total numbers were not typically in the hazardous category (World Health Organization, 2003; John Beaver, oral commun., 2012) and, therefore, were not considered a significant threat to the wildlife using the area.

As with phytoplankton and water quality, seasonality also played a large role in influencing density and biomass of zooplankton in Topock Marsh. During the low water sampling period (2011-12), the highest density and biomass occurred in February 2012 at TP-8 (fig. 24). Rotifers had the highest densities in February and March 2012, but cladocerans made up the bulk of the biomass throughout the study period.

Likewise, during the high water sampling period (2013-14), the greatest zooplankton bloom was observed in February 2014 throughout most of the marsh. The second largest bloom occurred in April 2014 (fig. 24). Rotifers again had the highest densities during those sampling events (fig. 24A) and cladocerans made up the majority of the biomass (fig. 24B). TP-6 contained the largest density and biomass of zooplankton during the February 2014 bloom; however, by April 2014, total biomass was highest at TP-8. In fact, zooplankton biomass at TP-8 was 7.7 times higher than all upstream stations in April 2014. Density and biomass of zooplankton were substantially lower in July through October during all of the study years, compared to February and April of all years, which suggest that a strong seasonal influence was most likely due to temperature.

Species richness for aquatic macroinvertebrates collected in Topock Marsh during the 4-year sampling period was 78 taxa, and the mean number of organisms obtained varied depending on sampling time and site (table 12). Overall, TP-8 had the largest number of macroinvertebrates collected with a mean $=321$ of total number of organisms collected during 10 sampling dates, followed by TP-2, TP-6, and TP-3. Both the average number of total taxa and total number of organisms increased appreciably from the 2011-12 sampling period 
to the 2013-14 sampling period; however, in 2013-14, more sampling trips were made (spring through fall) so it would be expected that a higher number and a wider diversity of macroinvertebrates would be collected.

Once quagga mussels were discovered in the marsh, we expected an increase in numbers of both the veliger and adults through time. However, only 12 adults and 20 veligers were collected in 2013, and 9 adults and 1 veliger were collected in 2014. No live adults were collected from the macroinvertebrate sampling in April or October 2014, and no other quagga mussels were seen elsewhere in the marsh. If monitoring for quagga mussels continues, FWS will be able to track any changes in the quagga population in the marsh should they occur. Caution is warranted, as literature suggests that the Havasu NWR's situation of having low-velocity water conveyance systems (that is, flow velocities less than $1.219 \mathrm{~m} / \mathrm{s}$ [4 ft/s]) in a nutrient rich aqueous environment might be the ideal scenario for quagga mussel colonization (Benson and others, 2016).

\section{Fish}

The annual AGFD gill net data (table 13 and figs. $25 \mathrm{~A}$ and $B$ ), plankton data (figs. 23 and 24), aquatic macroinvertebrate data (table 12), and water-quality data discussed in this report, suggest that Topock Marsh was suitable habitat for fish both before and after switching inflow from the Inlet Canal to the Fire Break Canal (fig. 1). However, if gizzard shad are excluded from the total number of fish captured per net in each region, the data show that most species of fish declined from 2010 to 2015. Therefore, perhaps more relevant to the fish population in the marsh is the correlation between the decline in numbers of most fish species when gizzard shad significantly increased in numbers (fig. 26). A decline in fish numbers after the appearance of gizzard shad in the lower Colorado River basin has previously been reported (Cantrell, 2013), and gizzard shad are considered a potential threat to native and recreational fisheries because of competition and predation (Mueller and Brooks, 2004). We cannot say unequivocally that the recent appearance of gizzard shad was due to infrastructure modifications, but that seems likely because the discovery of the gizzard shad was made following the completion of the new Fire Break Canal. In addition, it is known that this species has been proliferating in this region of the Colorado River for nearly a decade (Finney and Fuller, 2008; Loomis and others, 2011).

The inability to find razorback suckers in 2015 may not mean they are completely gone. Ten gill nets set during a oneweek period in February may miss representatives of this relatively small population of razorback suckers in a given year. However, it is troubling that their numbers were declining in 2013-14 and none were found in 2015. Continued yearly surveys should give biologists a better idea about the status of the razorback sucker population in Topock Marsh.

\section{Management Relevancy}

Based on the water-quality and aquatic-biota data that are summarized in this report, we can expect certain water management scenarios to potentially affect various parameters within Topock Marsh. The ideas expressed here are not suggestions, but instead can be used as information for the FWS, specifically water management staff at Havasu NWR, to better prepare for their future water management needs.

If low inflows and no outflow occur for any length of time in Topock Marsh, SC will increase throughout Topock Marsh, but particularly at the southern end of the marsh, as a result of the evaporation and concentration of solutes. Phytoplankton blooms will likely continue, causing increased turbidity and (or) increased toxic blue-green algae production. Lower water elevations will eventually occur under this scenario, which will encourage more emergent plant growth into currently open water areas and possibly less submerged vegetation growth because of potentially more turbid conditions. Although we found no evidence that there was less fish production because of shallower, more turbid, and warmer conditions, those conditions possibly could restrict quagga mussel and (or) Eurasian watermilfoil proliferation.

Once the planned infrastructure upgrades are completed, the low flow conditions of 2011-12 are less likely to reoccur. Adequate inflow from the Colorado River, potentially supplemented with pumped groundwater, and outflow through the South Dike will reduce the potential for evaporation-induced SC increases, concentration of nutrients, and subsequent phytoplankton blooms causing additional turbidity, as well as the potential for other stagnant water issues not addressed here (such as avian botulism, avian cholera, and so on) (U.S. Geological Survey, 1999). Greater water depths maintained at least through the end of June each year, will provide proper soil moisture for Southwestern willow flycatcher habitat (McLeod and Pellegrini, 2013) and control emergent vegetation proliferation but encourage SAV growth. Greater water depths could also reduce water temperatures during the summer, which would benefit fish (Beitinger and others, 2000), including gizzard shad.

The Havasu NWR's current practice of maintaining shallower water depths from late October through midDecember to provide better access to SAV for migrating and overwintering waterfowl is still a viable management practice. We suggest that additional adaptive management scenarios incorporating the many conflicting habitat needs can best be determined using a DSS tool developed for the Havasu NWR. Phase 1 of the Havasu NWR DSS, developed by USGS (Holmquist-Johnson and others, 2016), is a hindcasting model that can be used by the refuge managers to determine the total volume of water that must be added or subtracted throughout the year to meet a prescribed range of marsh elevations. Refuge managers, along with Reclamation engineers, can then determine the availability of Colorado River water and the most efficient method of delivering that specific volume of needed water to the marsh. 
Phase 2 of the Havasu NWR DSS, if funded, would build on the current Phase 1 hindcasting model DSS and would incorporate output from water management operations and hydrodynamic (that is, water quantity and quality) modeling based on marsh bathymetry, Colorado River hydrology, and future water delivery methods used by the Havasu NWR. Synthesis of these additional model outputs could allow FWS to compare different hydrologic scenarios and water management operations and delivery methods to determine their effects on species-specific habitat. Once these tools are developed, they could be valuable for, and directly applicable to, future analysis needs such as in-depth evaluation of climate change impacts. The Phase 2 DSS could be a powerful illustration of water management for optimized biological outcomes that could be applied to other locations beyond the Havasu NWR, thus providing resource managers the best available science to determine the most effective water management strategies.

\section{Conclusions}

At the request of the U.S. Fish and Wildlife Service Region 2 office, U.S. Geological Survey biologists conducted water quality and aquatic biota sampling from July 2011 to March 2012 to evaluate conditions at Topock Marsh, Arizona, during unusually low water elevations. Subsequently, sampling was resumed during 2013-14 to assess the same parameters under more normal water elevations (that is, higher inflows but no outflow). In total, the marsh was sampled 11 times at 4 sampling stations, denoted as TP-3, TP-2, TP-6, and TP-8, which were located north to south, from upstream to downstream, and parallel to the Colorado River. The most noteworthy findings are summarized here.

1. Turbidity levels in 2011 through early 2012 were high as prevailing winds stirred up loose sediments in the shallower water. Turbidity was generally lower in 2013-14 because water elevations were higher, with the exception of higher turbidities at the marsh terminus (measured at TP-8) because of high densities and biovolume of phytoplankton.

2. High turbidity levels decrease light penetration, which most likely discouraged submerged aquatic vegetation (SAV) growth in the more exposed areas of the marsh or under dense phytoplankton.

3. Spiny naiad (Najas marina) was the dominant SAV throughout Topock Marsh and was most abundant in shallow ( $0.60-0.76$ meters [2.0-2.5 feet] depth) protected areas where water clarity was relatively high. Sago pondweed (Stuckenia pectinata) occurred in low to moderate amounts in clear, typically shallower areas (0.30- 0.46 meters [ $1.0-1.5$ feet] depth). Virtually no rooted SAV was observed from January to March every year of the study, and all SAV species were most abundant in October of every year studied.
4. The unusually shallow water in 2011 , which was approximately 29.2 centimeters ( 0.96 feet) below average growing season levels, permitted existing stands of emergent plant species to expand laterally into water that was previously too deep. Simultaneously, cattail (Typha sp.) and California bulrush (Schoenoplectus californicus) roots and rhizomes growing at higher elevations were exposed to desiccating conditions under the high air temperatures. Even after surviving these stressful conditions, both cattail and California bulrush recovered in the following years and continued to thrive.

5. Three new nonnative aquatic species were discovered in 2012 following completion of the new Fire Break Canal: gizzard shad (Dorosoma cepedianum), quagga mussel (Dreissena bugensis) (both adult and veliger stages), and Eurasian watermilfoil (Myriophyllum spicatum). In 2012, a floating sprig of Eurasian watermilfoil was found but no rooted plants were reported. Gizzard shad and Eurasian watermilfoil increased in abundance through the study period, but the abundance of quagga mussels did not increase.

6. Quagga mussels and toxin-producing blue-green algae (Cyanobacteria) were found in low densities throughout the 2011-14 study period. We suspect that high turbidity levels and warm water temperatures may have slowed quagga mussel proliferation. Densities of blue-green algae measured from 2011 to 2014 did not typically reach levels in the hazardous category, but the potential for hazardous blooms is possible under warm water temperatures and no-to low-flow conditions.

7. Fish abundance exhibited no measurable signs of impact from water elevation or water quality changes throughout the study period. Although species richness of phytoplankton, zooplankton, and aquatic macroinvertebrates indicated that adequate food was available for fish as well as other wildlife, some fish species in Topock Marsh may have been negatively impacted by the sudden increase in gizzard shad. The population of the endangered razorback sucker (Xyrauchen texanus), which was reintroduced in 2010, appeared to be thriving and in good condition, with numbers captured in gill net surveys peaking in 2012. However, their numbers declined in 2013 and 2014, and none were captured in 2015 .

8. Following the 260-day period of no flow through the Inlet Canal in 2011, Colorado River water flowing into the marsh through the new Fire Break Canal lowered specific conductance (SC), total dissolved solids, turbidity, chlorophyll $a$, total and organic nitrogen, and phytoplankton concentrations at the upstream sampling stations, and pushed water with higher concentrations downstream. Comparing these SC concentrations with historical data reveal that average SC values in the marsh from when the Fire Break Canal became operational 
(January 2012) to January 2015 are only slightly higher (1.12 times) than values reported in another study for 1995-1998. Those time periods did not experience the previous extremes (highs and lows) that occurred between late 1987 and May 1994 and between late 2003 and January 2011 when fairly consistent trends of SC concentrations peaking during the winter prior to spring water releases from Davis Dam were apparent.

9. Concentrations of nutrients and trace elements (including arsenic, mercury, selenium, and hexavalent chromium) in water, sediment (with one slightly elevated exception for arsenic), and plant samples were below toxicity thresholds throughout the sampling period.

10. Further monitoring and statistical analysis are necessary to evaluate the long-term effects of the nonnative biota (that is, quagga mussels, gizzard shad, and Eurasian watermilfoil), as well as subsequent changes in water management, on the native aquatic flora, fauna, and water quality of Topock Marsh.

\section{Acknowledgments}

We would like to thank the U.S. Geological Survey (USGS) for their base support for this project; Chris HolmquistJohnson, Leanne Hanson, and Doug Andersen of the USGS Fort Collins Science Center for their invaluable assistance and advice throughout the project; and Johanna Kraus and Lindsay Reynolds, USGS Fort Collins Science Center, for their assistance in the editing of this and an earlier document.

We would also like to thank the Bureau of Reclamation Technical Service Center in Denver, Colorado, for their support in this project; the U.S. Fish and Wildlife Service Region 2 for funding the work reported herein, particularly Andrew Hautzinger for his continued support and patience; the Havasu National Wildlife Refuge (NWR) staff, plus Mitch Thorson and Rob Randall of the Arizona Fish and Wildlife Conservation Office, and their respective staffs who helped us fulfill this task in so many ways; Janet Kirsch, Chris Pope, Chris Dodge, Barbara Raulston, and Joe Kahl of Reclamation, Lower Colorado Region; Rick Wydoski, Eric Best, and Scott O’Meara of Reclamation, Technical Service Center; C. Doug Adams, Bureau of Land Management; and Gregg Cummins, Arizona Game and Fish Department, for sharing their data and knowledge; plus Andrew Hautzinger, Joaquin Baca, Brenda Zaun, Jessica Gwinn, Linda L. Miller, and Daryl Magnuson, all of the U.S. Fish and Wildlife Service Region 2, for their invaluable assistance in the editing of this document. A special thanks to volunteer Marge Penton for her invaluable assistance in the field, as well as the Student Conservation Association interns at Havasu National Wildlife Refuge who provided assistance with numerous data collection efforts. Without everyone's involvement and assistance, this work could not have been performed.

\section{References Cited}

Alanen, M.I., 1998, Factors affecting the distribution and abundance of submersed aquatic vegetation in Topock Marsh, an impounded desert wetland: Tucson, Ariz., University of Arizona, M.S. thesis, 64 p.

American Public Health Department, American Water Works Association, and Water Environment Federation, 1995, Standard methods for the examination of water and wastewater (19th ed.): Baltimore, Md., United Book Press, Inc., $157 \mathrm{p}$.

Andersen, D.C., Sartoris, J.J., Thullen, J.S., and Reusch, P.G., 2003, The effects of bird use on nutrient removal in a constructed wastewater-treatment wetland: Wetlands, v. 23, p. 423-435.

Arizona Department of Environmental Quality [ADEQ], 2009, Water quality standards for surface waters-Unofficial copy of final rules: Arizona Department of Environmental Quality, 18 A.A.C. 11, Art.1, 132 p., accessed January 9, 2012, at http://www.azdeq.gov/environ/water/standards/download/ SWQ_Standards-1-09-unofficial.pdf.

Barko, J.W., and Smart, R.M., 1981, Sediment-based nutrition of submersed macrophytes: Aquatic Botany, v. 10, p. 339-352.

Beitinger, T.L., Bennett, W.A., and McCauley, R.W., 2000, Temperature tolerances of North American freshwater fishes exposed to dynamic changes in temperature: Environmental Biology of Fishes, v. 58, p. 237-275.

Benson, A.J., Richerson, M.M., Maynard, E., Larson, J., Fusaro, A., Bogdanoff, A.K., and Neilson, M., 2016, Dreissena rostriformis bugensis: U.S. Geological Survey Nonindigenous Aquatic Species Database, Revision Date: 1/7/2016, accessed September 29, 2016, at https://nas.er.usgs.gov/queries/factsheet.aspx? speciesid=95.

Bovee, K.D., 1986, Development and evaluation of habitat suitability criteria for use in the instream flow incremental methodology: Washington, D.C., U.S. Fish and Wildlife Service, Instream Flow Information Paper \#21, FWS/ OBS-86/7, $235 \mathrm{p}$.

Bureau of Reclamation, 2009, Standard operating procedures (SOP) -Water quality sampling: Blythe, Calif., Bureau of Reclamation, Blythe Hydrographic Office Water Quality Program, $26 \mathrm{p}$.

Cantrell, C., 2013, Conservation Alert - Gizzard Shad on Roosevelt, in Arizona Bass Federation, Conservation News, April 17, 2013: Chandler, Ariz., Arizona Bass Federation, accessed July 30, 2015, at http:/www.azbassfederation.com/ 2013/04/17/conservation-alert-gizzard-shad-on-roosevelt/.

Chui, C.R., and Jirka, G.H., 2003, Wind and stream flow induced reaeration: Journal of Environmental Engineering, v. 129, p. 1129-1136.

Cronk, J.K., and Fennessy, M.S., 2001, Wetland plantsBiology and ecology: Boca Raton, Fla., CRC Press, 462 p. 
Dumont, H.J., Van de Velde, I., and Dumont, S., 1975, The dry weight estimate of biomass in a selection of Cladocera, Copepoda and Rotifera from the plankton, periphyton and benthos of continental waters: Oecologia, v. 19, p. 75-97.

Dzialowski, A.R., Smith, V.H., Wang, S.H., Martin, M.C., and deNoyelles Jr., F., 2011, Effects of non-algal turbidity on cyanobacterial biomass in seven turbid Kansas reservoirs: Lake and Reservoir Management, v. 27, p. 6-14.

Eaton, A.D., Clesceri, L.S., Rice, E.W., and Greenberg, A.E., 2005, Standard methods for the examination of water and wastewater (21st ed.): Washington, D.C., American Public Health Association, 1,368 p.

Eisler, R., 1988, Arsenic hazards to fish, wildlife, and invertebrates-A synoptic review: Laurel, Md., U.S. Fish and Wildlife Service, Patuxent Wildlife Research Center, Biological Report 85(1.12), $92 \mathrm{p}$.

Finney, S.T., and Fuller, M.H., 2008, Gizzard shad (Dorosoma cepedianum) expansion and reproduction in the upper Colorado River Basin: Western North American Naturalist, v. 68, p. 524-525.

Gee, G.W., and Bauder, J.W., 1986, Particle size analysis, Method 15-5 Hydrometer Method, chap. 15 of A. Klute, ed., Methods of soil analysis, Part 1-Physical and mineralogical methods ( $2 \mathrm{~d}$ ed.): Madison, Wis., American Society of Agronomy, Soil Science Society of America, 404 p.

Guay, B.E., 2001, Preliminary hydrologic investigation of Topock Marsh, Arizona 1995-98: Tucson, Ariz., University of Arizona, Ph.D. dissertation, 335 p.

Hillenbrand, H., Dürselen, C.D., Kirschtel, D., Pollingher, U., and Zohary, T., 1999, Biovolume calculation for pelagic and benthic microalgae: Journal of Phycology, v. 35, p. 403-424.

Holmquist-Johnson, C., Hanson, L., Daniels, J., Talbert, C., and Haegele, J., 2016, Development of a decision support tool for water and resource management using biotic, abiotic, and hydrological assessments of Topock Marsh, Arizona: U.S. Geological Survey Open-File Report 2016-1065, 121 p., http://dx.doi.org/10.3133/ofr20161065.

Kabata-Pendias, A., and Pendias, H., 2001, Trace elements in soils and plants ( $3 \mathrm{~d}$ ed.): Boca Raton, Fla., CRC Press LLC, $331 \mathrm{p}$.

Kadlec, R.H., and Wallace, S.D., 2009, Treatment wetlands (2d ed.): Boca Raton, Fla., CRC Press, 1,016 p.

Lawrence, S.G., Malley, D.F., Findlay, W.J., MacIver, M.A., and Delbaere, I.L., 1987, Method for estimating dry weight of freshwater planktonic crustaceans from measures of length and shape: Canadian Journal of Fisheries and Aquatic Sciences, v. 44, p. 264-274.

Lemly, A.D., 2002, Selenium assessment in aquatic ecosystems-A guide for hazard evaluation and water-quality criteria: New York, Springer-Verlag, $161 \mathrm{p}$.

Lieberman, D.M., and Grabowski, S.J., 2007, Physical, chemical, and biological characteristics of Cle Elum and Bumping Lakes in the Upper Yakima River Basin: Denver, Colo., Bureau of Reclamation Technical Series No. PN-YDFP-005, 83 p.
Loomis, E.M., Sjöberg, J.C., Wong, W.H., and Gerstenberger, S.L., 2011, Abundance and stomach content analysis of threadfin shad in Lake Mead, Nevada - Do invasive quagga mussels affect this prey species?: Aquatic Invasions, v. 6, p. 157-168.

Lopez, C.B., Jewett, E.B., Dortch, Q., Walton, B.T., and Hudnell, H.K., 2008, Scientific assessment of freshwater harmful algal blooms: Washington, D.C., Interagency Working Group on Harmful Algal Blooms, Hypoxia, and Human Health of the Joint Subcommittee on Ocean Science and Technology, $78 \mathrm{p}$.

MacDonald, D.D., Ingersoll, C.G., and Berger, T., 2000, Development and evaluation of consensus-based sediment quality guidelines for freshwater ecosystems: Archives of Environmental Contamination and Toxicology, v. 39, p. 20-31.

Mackie, G.L., and Claudi, R., 2010, Monitoring and control of macrofouling mollusks in fresh water systems ( $2 \mathrm{~d}$ ed.): Boca Raton, Fla., CRC Press, Taylor \& Francis Group, 508 p.

McCauley, E., 1984, The estimation of the abundance and biomass of zooplankton in samples, in Downing, J.A., and Rigler, F.H., eds., A manual on methods for the assessment of secondary productivity in fresh waters: Boston, Blackwell Scientific Publishers, p. 228-265.

McLeod, M.A., and Pellegrini, A.R., 2013, Southwestern willow flycatcher surveys, demography, and ecology along the lower Colorado River and tributaries, 2008-2012, summary report: Boulder City, Nev., Bureau of Reclamation, prepared by SWCA Environmental Consultants under contract number GS-10F-0209L, $341 \mathrm{p}$.

Miller, R.O., and Kotuby-Amacher, J., 1994, Western States agricultural laboratory exchange program - Suggested soil and plant analytical methods, Version 1.00 Fort Collins, Colo., Colorado State University, Western States Program, p. $42-54$.

Mueller, G.A., and Brooks, J.E., 2004, Collection of an adult gizzard shad (Dorosoma cepedianum) from the San Juan River, Utah: Western North American Naturalist, v. 64, p. 135-136.

National Oceanic and Atmospheric Administration, 2016, Data Tools - Find a Station: Ashville, N.C., National Oceanic and Atmospheric Administration, accessed September 2012 to September 2016, at http://www.ncdc.noaa.gov/cdo-web/ datatools/findstation.

Nelson, S.M., Roline, R.A., Thullen, J.S., Sartoris, J.J., and Boutwell, J.E., 2000, Invertebrate assemblages and trace element bioaccumulation associated with constructed wetlands: Wetlands, v. 20, p. 406-415.

Neter, J., Kutner, M.H., Nachtsheim, C.J., and Wasserman, W., 1996, Applied linear statistical models, 4th Edition: Irwin, Chicago, McGraw-Hill, 1408 p.

Reddy, K.R., and DeLaune, R.D., 2008, Biogeochemistry of wetlands: Boca Raton, Fla., CRC Press, Taylor \& Francis Group, 774 p. 
Roosevelt, F.D., 1941, Executive Order 8647-Establishing the Havasu Lake National Wildlife Refuge, Arizona and California: Washington, D.C., U.S. Government Printing Office, 6 Federal Register 593, January 25, 1941.

Sakamoto, Y., Ishiguro, M., and Kitagawa, G., 1986, Akaike information criterion statistics: Tokyo, KTK Scientific Publishers, $290 \mathrm{p}$.

Salisbury, F.B., and Ross, C., 1969, Plant physiology: Belmont, Calif., Wadsworth Publishing Co. Inc., 747 p.

Sand-Jensen, K., and Borum, J., 1991, Interactions among phytoplankton, periphyton, and macrophytes in temperate freshwaters and estuaries: Aquatic Botany, v. 41, p. 137-175.

Shoreline Engineering and Restoration, 2006, Havasu National Wildlife Refuge water management plan, final: Albuquerque, N. Mex., U.S. Fish and Wildlife Service, prepared by Shoreline Engineering and Restoration, 44 p., 9 apps., accessed September 30, 2016, at http://www.lcrmscp.gov/ reports/2006/e17_havasu_wmp_sep06.pdf.

U.S. Department of Agriculture, 1996, Method 8C1b, in Soil survey laboratory methods manual- Soil Survey Investigations Report No. 42, Version 3.0: U.S. Department of Agriculture, Natural Resources Conservation Service, National Soil Survey Center, $411 \mathrm{p}$.

U.S. Department of the Interior [DOI], 2009, Draft environmental assessment for the Topock Marsh water infrastructure improvement project on the Havasu National Wildlife Refuge, Arizona: Albuquerque, New Mexico, U.S. Fish and Wildlife Service 34 p., accessed on 9/30/2016 at http://www.fws.gov/southwest/ images/Topock\%20DRAFT\%20EA\%2018NOV09.pdf.

U.S. Environmental Protection Agency, 1986a, Ambient water quality criteria for dissolved oxygen-Freshwater: Washington, D.C., U.S. Environmental Protection Agency, Office of Water Regulations and Standards, EPA 440/5-86-003, $46 \mathrm{p}$.

U.S. Environmental Protection Agency, 1986b, Solid or SemiSolid Waste (Manual Cold Vapor Technique). Test methods for evaluating solid waste ( $3 \mathrm{~d}$ ed.): Washington, D.C., U.S. Government Printing Office, 1,025 p.

U.S. Environmental Protection Agency, 2004, Draft aquatic life water quality criteria for selenium-2004: Washington, D.C., U.S. Environmental Protection Agency, Office of Water, EPA-822-D-04-001, 344 p.

U.S. Environmental Protection Agency, 2012, National recommended water quality criteria, aquatic life criteria table: U.S. Environmental Protection Agency, accessed January 5, 2012, at http://water.epa.gov/scitech/swguidance/standards/ criteria/current/index.cfm.
U.S. Fish and Wildlife Service, 1966, Endangered Species Act, A History of the Endangered Species Act of 1973, Timeline: U.S. Fish and Wildlife Service, accessed September 13, 2016, at https://www.fws.gov/endangered/laws-policies/ timeline.html.

U.S. Geological Survey, 1999, Field manual of wildlife diseases - General field procedures and diseases of birds: U.S. Geological Survey Information and Technology Report 1999-001, 426 p.

U.S. Geological Survey, 2016a, USGS 09423560 Firebreak Canal at Havasu NWR Near Needles, CA: U.S. Geological Survey, National Water Information System: Web Interface, accessed January 2012 to September 2016, at http://nwis.waterdata.usgs.gov/nwis/ inventory/?site_no=09423560\&agency_cd=USGS.

U.S. Geological Survey, 2016b, NWQL Water-Resources Reports: U.S. Geological Survey, National Water Quality Laboratory, accessed July 2011 to September 2016, at http://nwql.usgs.gov/rpt.shtml?pubs.

U.S. Geological Survey, 2016c, Nonindigenous aquatic species: U.S. Geological Survey, accessed September 27, 2016, at http://nas.er.usgs.gov/taxgroup/plants/.

Vymazal J., 1995, Algae and element cycling in wetlands: Boca Raton, Fla., Lewis Publishers, 700 p.

Waisel, Y., and Agami, M., 1983, Are roots essential for normal growth of Najas marina L.?, in International Symposium on Aquatic Macrophytes, September 18-23, 1983, Proceedings: Nijmegen, The Netherlands, p. 287-291.

WeatherSpark Beta, 2016, Average Weather For Needles, California, USA: WeatherSpark Beta, accessed September 2014 to September 2016, at https://weatherspark.com/ averages/30144/Needles-California-United-States.

Weather Underground, 2016, Needles, California: Weather Underground, accessed September 2012 to September 2016, at http://www.wunderground.com/history/airport/ KEED/2011/7/1/CustomHistory.html?.

Workman, S.M., Soltanpour, P.N., and Follet, R.H., 1988, Soil testing methods used at Colorado State University for the evaluation of fertility, salinity, and trace element toxicity: Fort Collins, Colo., Colorado State University, Agricultural Experiment Station Technical Bulletin LTB88-2, 22 p.

World Health Organization, 2003, Algae and Cyanobacteria in fresh water, chap. 8 of Guidelines for safe recreational water environments, Volume $1-$ Coastal and fresh waters: Geneva, World Health Organization, $253 \mathrm{p}$.

Young, N.E., West, A., Anderson, R.S., Chignell, S., Evangelista, P.H., and Jarnevich, D., 2015, Mapping land cover and invasive tamarisk in Havasu National Wildlife Refuge, AZ: Fort Collins, Colo., Colorado State University, Natural Resource Ecology Laboratory, 23 p. 



\section{Appendix 1. Long-Term Water Chemistry Data for Topock Marsh From Late 1983 to Early 2015}

The Excel spreadsheet Appendix-1.xls provides long-term chemistry data for Topock Marsh, Arizona from November 1983 to April 2015. 


\section{Appendix 2. Topock Marsh General Fish Surveys and Reports}

- Topock Marsh General Fish Surveys 2010 and 2011-Excel tables by Gregg Cummins and Matt Chmiel, Arizona Game and Fish Department (AGFD), February 2010 and February 2011, 2 tables in spreadsheet.

- Topock Marsh General Fish Survey 2012 by Gregg Cummins, David Partridge, and Matt Chmiel, AGFD, February 2012, $2 \mathrm{pg}$.

- Topock Marsh General Fish Survey 2013 by Gregg Cummins and David Partridge, AGFD, February 2013, 2 pg.

- Topock Marsh Fish Survey Report—February 2014 by Gregg Cummins, AGFD, April 2014, 6 pg.

- Topock Marsh Fish Survey Report-February 2015 by Gregg Cummins, AGFD, March 2015, 8 pgs. 
Publishing support provided by:

Denver Publishing Service Center, Denver, Colorado

For more information concerning this publication, contact:

Center Director, USGS Fort Collins Science Center

2150 Centre Ave., Bldg. C

Fort Collins, CO 80526-8118

(907) 226-9398

Or visit the Fort Collins Science Center Web site at: http://www.fort.usgs.gov/

This publication is available online at: https://doi.org/10.3133/ofr20161195 



\section{$\frac{\mathbb{3}}{\mathrm{W}}$}

ㅁ․
$\stackrel{0}{\frac{D}{D}}$
$\frac{0}{\infty}$

登

工

这

D

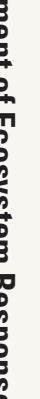

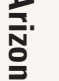

I

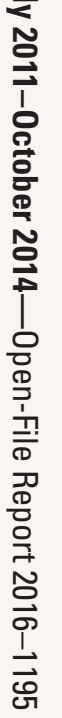

